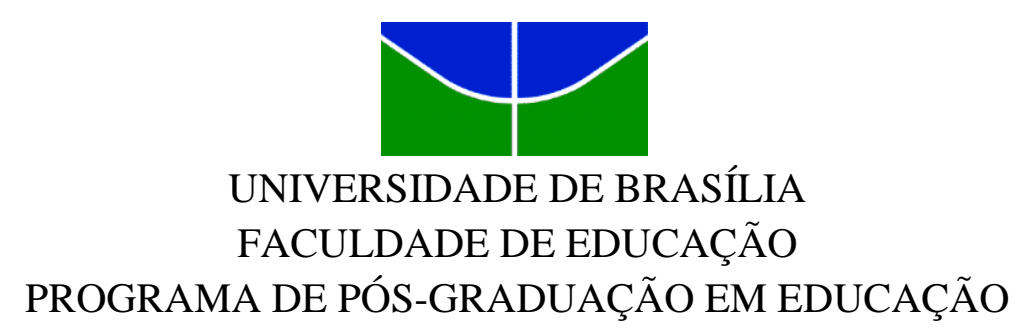

\title{
A APRENDIZAGEM CRIATIVA EM CONTEXTOS NÃO-FORMAIS: CARACTERIZAÇÃO E PROCESSOS SUBJETIVOS CONSTITUTIVOS
}

PILAR DE ALMEIDA

Brasília, 2015 
UNIVERSIDADE DE BRASÍLIA

FACULDADE DE EDUCAÇÃO

PROGRAMA DE PÓS-GRADUAÇÃO EM EDUCAÇÃO

\section{A APRENDIZAGEM CRIATIVA EM CONTEXTOS NÃO-FORMAIS: CARACTERIZAÇÃO E PROCESSOS SUBJETIVOS CONSTITUTIVOS}

PILAR DE ALMEIDA

Tese apresentada ao Programa de PósGraduação em Educação da Faculdade de Educação da Universidade de Brasília/Unb como parte dos requisitos para a obtenção do título de Doutor em Educação, na área de Escola, Aprendizagem e Trabalho Pedagógico.

Orientadora Profa Dra Albertina Mitjáns Martínez

Brasília, abril de 2015 


\title{
A APRENDIZAGEM CRIATIVA EM CONTEXTOS NÃO-FORMAIS: CARACTERIZAÇÃO E PROCESSOS SUBJETIVOS CONSTITUTIVOS
}

\author{
BANCA EXAMINADORA:
}

Profa Dra Albertina Mitjáns Martínez

Faculdade de Educação - UnB

Orientadora

\author{
Profa Dra Luciana Sepúlveda Köptcke \\ Instituto Oswaldo Cruz \\ Examinadora externa
}

Profa Dra Ana Valéria Marques Fortes Lustosa Departamento de Fundamentos da Educacao - UFPI Examinadora externa

Profa Dra Maria Alexandra Militão Rodrigues

Faculdade de Educação - UnB

Examinadora interna

Profa Dra Maria Carmen Villela Rosa Tacca

Faculdade de Educação - UnB

Examinadora interna

Profa Dra Mariangela Momo

Faculdade de Educação - UFRN

Examinadora suplente 


\section{AGRADECIMENTOS}

Às participantes da pesquisa, pela confiança, pelo carinho e por me ensinarem tanto sobre o aprender.

À toda a equipe do Projeto, pela enorme receptividade, abertura e carinho com que me acolheram.

Aos professores do Programa de Pós-Graduação em Educação, por momentos maravilhosos de diálogo e de instigação à reflexão, que me acompanham até hoje.

À coordenação e à secretaria do Programa de Pós-Graduação em Educação, pela confiança e apoio nos momentos de desatar nós dos processos burocráticos.

Às queridas colegas do grupo de orientação, Tatiana, Luciana, Valdívia e Fran, pela enorme parceria em todas as dimensões.

Um especial agradecimento à Profa. Albertina, pela incrível paciência e confiança. Sua condução da orientação, ao mesmo tempo livre e precisa, me fez querer me superar sempre e me surpreender com minha própria autoria de pensamento. (Que sabedoria é essa?)

Ao meu pai, minha avó e a toda minha família, de longe e de perto, que eu amo tanto, e de quem estive tantos momentos ausente.

À minha mãe pelas palavras certas nas horas certas, na melhor tradição da subjetividade.

À Ana Carol, que permitiu que tudo fosse possível.

Ao Rodrigo, meu querido e amado esposo, que ao seu modo sempre me apoiou e foi um enorme parceiro na logística da vida. E, por fim, aos meus filhos que, nos sorrisos e nas mãnhas, me recarregam as energias.

Meus sinceros agradecimentos a RNP pela flexibilidade com que me acolheu de forma a tornar possível minha efetiva dedicação ao doutoramento. 


\section{RESUMO}

Abordamos, nesta pesquisa, o tema da aprendizagem criativa em contextos de educação não-formal, motivados por questões iniciais tais como: qual o papel de espaços sociais na aprendizagem? Como uma pessoa aprende criativamente em contextos menos estruturados do aprender? Como o aprendizado criativo no contexto não-formal, é "retomado" em outros contextos de vida? Assumimos a educação não-formal, como aquela que ocorre em qualquer atividade educativa organizada fora do sistema formal, em contraposição àquela que ocorre nos contextos formal e informal. Ressaltamos características comumente associadas à educação não-formal, tais como a não obrigatoriedade, a ausência de rotinas de estudo e de instrução sistemática, o apelo ao lúdico, a ausência de métodos avaliativos, a liberdade e autonomia de escolha sobre o que aprender, entre outros. Para a pesquisa, partimos da hipótese interpretativa inicial de que características e processos subjetivos constitutivos da aprendizagem criativa em contextos não-formais guardam especificidades próprias destes contextos. Tínhamos, assim, como objetivo geral: compreender a configuração subjetiva da ação do aprender e formas de expressão da aprendizagem criativa em um contexto de educação não-formal. Adotamos, como arcabouço teórico central, os estudos de Mitjáns Martínez sobre a criatividade como processo da subjetividade humana, e a Teoria da Subjetividade, compreendida sob o enfoque HistóricoCultural, conforme proposta por González Rey. Como caminho metodológico, com base na Epistemologia Qualitativa realizamos três estudos de caso com participantes de uma ação educativa não-formal, de divulgação científica. Para a construção das informações, utilizamos instrumentos como observação, análise documental, entrevistas, redação, completamento de frases, conversas informais, entre outros. A partir do processo construtivo interpretativo da pesquisa, subscrevemos formulações existentes sobre características e processos subjetivos constitutivos da aprendizagem criativa tais como a personalização da informação, a confrontação com o dado, a geração de ideias, o exercício da condição de sujeito, a aprendizagem que retroalimenta novas aprendizagens, entre outros. Nossas análises, no entanto, nos permitiram revisar a formulação sobre a personalização da informação ampliando-a para a personalização do próprio aprendizado. Permitiram-nos ainda duas novas contribuições: o estudo empírico da expressão singular da subjetividade social na subjetividade individual do aprendiz e a construção teórica sobre personalização da experiência da aprendizagem. Com base nessas elaborações, formulamos a tese de que características e processos subjetivos constitutivos da aprendizagem criativa em contextos não-formais possuem especificidades próprias desses contextos e são marcados pela ênfase na maior autonomia por parte do aprendiz nos processos de seleção do que se aprende e da forma como se aprende. Consideramos que os processos subjetivos constitutivos, por nós elaborados, integram a capacidade autônoma, do aprendiz, de converter a própria experiência em aprendizagem o que se torna um recurso subjetivo, em contextos menos estruturados, como os contextos não-formais. 


\section{ABSTRACT}

In this research, we approach the theme of creative learning in non-formal education contexts. Part of our motivation were initial questions such as: what is the role of social spaces in learning? How does a person learn creatively in less structured learning contexts? How does the learnt in non formal contexts "emerge" in other contexts of life? We assume non formal education, the one which occurs in any organized educational activity outside the formal system, as opposed to one which occurs in formal and informal contexts. We stress characteristics commonly associated with non-formal education, such as the non-compulsory aspect, the absence of study routines and systematic instruction, the appeal to the ludic, the absence of evaluation methods, the freedom and autonomy of choice over what to learn, among others. We part from an initial interpretative hypothesis that characteristics and constitutive subjective processes of creative learning in informal contexts keep specificities of such contexts. Our general objective was to understand the subjective configuration of the action of learning as well as forms of expression of creative learning in a non-formal education context. Central to our study were the theoretical studies of Mitjáns Martínez on creativity as a process of human subjectivity, and the Theory of Subjectivity, taken from a HistoricCultural perspective, as proposed by González Rey. As for the methodological approach, we considered the Qualitative Epistemology conducting three case studies with participants of a non-formal educational activity on science popularization. For the research's information construction, we used research tools such as observation, document analysis, interviews, writing, completion of sentences, informal conversations, among others. As a result of our research interpretative constructions, we endorse existing formulations on the characteristics and constitutive subjective processes of creative learning, such as the personalization of information, the confrontation with the data, the generation of ideas, the subject condition, the learning that feeds back new learning, among others. Our analysis, however, allowed us to review the conceptualization of the personalization of information extending it to the personalization of the learnt. Our analysis also permitted us two new contributions: the empirical analysis of the singular expression of social subjectivity in the individual subjectivity of the learner, and the theoretical construction of personalization of the learning experience. Based on these elaborations, we formulated the thesis that characteristics and constitutive subjective processes of creative learning in non formal contexts have their own specificities and are marked by a greater emphasis on the autonomy of the learner in the selection processes of what to learn and how to learn. Such processes take into account the capacity of the learner to autonomously convert his/her experience to a learning experience. A capacity the becomes a relevant subjective resource in less structured learning settings, like non-formal contexts. 


\section{RESUMÉ}

Cette recherche aborde le thème de l'apprentissage créatif dans des contextes d'éducation non formelle. Notre motivation étaient questions initiales, telles que: quel est le rôle des espaces sociaux dans l'apprentissage? Comme une personne apprend de façon créative dans des contextes d'apprentissage moins structurées? Comme l'apprentissage créatif dans un contexte non formelle "émerge" dans d'autres contextes de la vie? Nous comprenons l'éducation non formelle celle qui se produit dans toute activité éducative organisée en dehors du système formel, par opposition à ce qui se produit dans des contextes formels et informels. Nous soulignons les caractéristiques généralement associées à l'éducation non formelle, comme l'aspect non obligatoire, l'absence de programmes d'étude et de l'enseignement systématique, l'appel à la ludique, l'absence de méthodes d'évaluation, l'autonomie de choix sur ce qu'il faut apprendre, entre autres. Pour la recherche, nous partons de l'hypothèse interprétative initiale que les caractéristiques et les processus subjectifs constitutives d'apprentissage créatif dans des contextes non formels détiennent spécificités de ces contextes. L'objectif général de notre recherche était de comprendre la configuration subjective de l'action de l'apprentissage et les formes d'expression de l'apprentissage créatif dans un contexte d'éducation non formelle. Nous considérons comme une base théorique les études de Mítjáns Martínez sur la créativité comme un processus de la subjectivité humaine, et la Théorie de la Subjectivité, compris dans la perspectif historico-culturelle, proposé par González Rey. Comme approche méthodologique, sur la base de la Épistémologie Qualitative, nous avons analysé trois études de cas avec les participants d'une activité d'éducation non formelle, sur la diffusion scientifique. Pour la construction de l'information, nous utilisons des outils de recherche tels que l'observation, l'analyse de documents, interviews, écriture, exécution des jugements, des conversations informelles, entre autres. À la suite de notre constructions interprétatifs, nous appuyons les formulations existantes sur les charactéristiques et les processus subjectifs constitutifs de l'apprentissage créatif, tels que la personnalisation des informations, la confrontation à l'information, la génération d'idées, l'état du sujet, l'apprentissage qui favorise nouvelles apprentissages, entre autres. Notre analyse, toutefois, nous a permis la révision de la notion de personnalisation d'information étendant cette notion pour la personnalisation de l'appris. Aussi permis deux nouvelles contributions: l'analyse empirique de l'expression unique de la subjectivité sociale dans la subjectivité individuelle de l'apprenant et la construction théorique sur la personnalisation de l'expérience d'apprentissage. Sur la base de cettes élaborations, nous avons formulé la thèse selon laquelle les charactéristiques et les processus subjectifs constitutifs de l'apprentissage créatif dans des contextes non formels ont leurs propres spécificités et ceuxci sont marquées par une plus grande autonomie de l'apprenant dans les processus de sélection de ce qui s'apprendre et de la manière comment s'apprendre. Nous croyons que les processus subjectifs constitutifs, développés par notre recherche, intègrent la capacité autonome, de l'apprenant, de convertir son expérience en appredissage ce que devient un ressource subjectif, dans les contextes moins structurés d'apprendissage, comme des contextes non formels. 


\section{SUMÁRIO}

INTRODUÇÃO.

CAPÍTULO I: Pesquisas sobre aprendizagem no contexto não-formal: o caso exemplar da aprendizagem em museus................ 22

1.1. Revisão da produção científica sobre aprendizagem em museus.... 24

1.1.1. Pesquisas de bases construtivistas...................................... 25

1.1.2. A Teoria SocioCultural....................................................... 27

1.1.3. A Teoria da Atividade, a partir da perspectiva histórico-

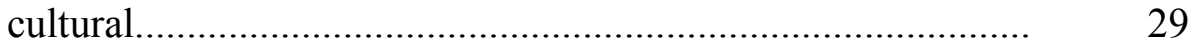

1.1.4. O Modelo Contextual........................................................ 32

1.2. As Pesquisas sobre identidade de aprendizagem........................... 35

1.3. Pesquisas sobre a Relação Museu-Escola....................................... 37

CAPÍTULO II - Arcabouço teórico central................................................. 40

2.1. A Teoria da Subjetividade de Fernando González Rey................... 40

2.2. Movimentos da Subjetividade........................................................ 48

2.2.1. O Desenvolvimento da Subjetividade................................ 48

2.2.2. Impacto, Mudança e Desenvolvimento da Subjetividade..... 52

2.3. A Dimensão Subjetiva da Aprendizagem...................................... 53

2.4. O papel do social e a dimensão do Outro na aprendizagem............ 55

2.5. A aprendizagem criativa........................................................ 57

2.5.1. A criatividade como processo da subjetividade.................... 58

2.5.2. Características e processos subjetivos constitutivos da aprendizagem criativa................................................... 62

CAPÍTULO III- Metodologia da Pesquisa................................................ 67

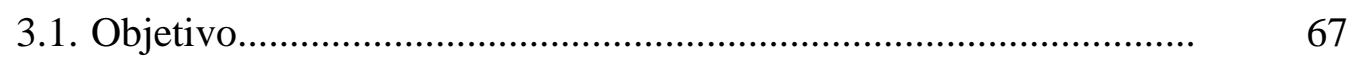

3.2. A Epistemologia Qualitativa..................................................... 67

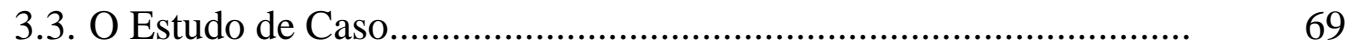

3.4. A construção do cenário de pesquisa............................................ 69

3.5. A seleção dos participantes da pesquisa......................................... 71

3.6. O campo de estudo................................................................. 71

3.7. Instrumentos e procedimentos de pesquisa................................... 77 
CAPÍTULO IV - Análises das informações e construções teóricas: ..... $\quad 87$

4.1. A participante Camile................................................................... 88

4.1.1. A caracterização de Camile.................................................. 88

4.1.2. A configuração subjetiva da ação de aprender em Camile

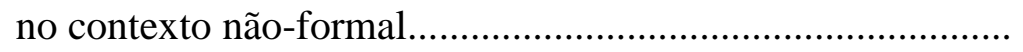

4.1.2.1. Elementos de sentidos subjetivos relacionados à subjetividade social do contexto não-formal..............

4.1.2.2. Núcleos de sentidos subjetivos organizados a partir da trajetória de vida e na ação de Camile no contexto não-formal..

4.1.3. Características da Aprendizagem de Camile no contexto não-formal.

4.1.3.1. Personalização da informação.

4.1.3.2. A Confrontação com o dado

4.1.3.3. A geração de ideias novas

4.1.3.4. A personalização da experiência de aprendizagem.....

4.2.1. A caracterização de Estela e a expressão da subjetividade social do contexto formal em sua subjetividade individual....

4.2.2. A configuração subjetiva da ação de aprender em Estela no contexto não-formal.

4.2.2.1. Elementos de sentidos subjetivos relacionados à subjetividade social do contexto não-formal

4.2.2.2. Núcleos de sentidos subjetivos organizados a partir da trajetória de vida e na ação de Estela no contexto não-formal

4.2.3. Características da Aprendizagem de Estela no contexto não-formal.

4.2.3.1. A personalização da informação.

4.2.3.2. A personalização da experiência de aprendizagem..... 
4.3.1. A caracterização de Mika e a expressão da subjetividade social do contexto formal em sua subjetividade individual....

4.3.2. A configuração subjetiva da ação de aprender em Mika no contexto não-formal.

4.3.2.1. Elementos de sentidos subjetivos relacionados à subjetividade social do contexto não-formal

4.3.2.2. Núcleos de sentidos subjetivos organizados a partir da trajetória de vida e na ação de Mika no contexto não-formal

4.3.3. Características da aprendizagem de Mika no contexto não-formal

4.3.3.1. Personalização da informação.

4.3.3.2. A confrontação com o dado

4.3.3.3. A geração de ideias novas

4.3.3.4. A personalização da experiência de aprendizagem.....

4.4. Síntese Integrativa dos Casos: considerações sobre processos constitutivos da aprendizagem criativa no contexto não-formal........

4.4.1. A personalização da experiência da aprendizagem

4.4.2. A expressão singular da subjetividade social na subjetividade individual do aprendiz

4.4.3. A personalização do aprendizado e sua relação com processos de mudanças na subjetividade do aprendiz 


\section{LISTA DE ILUSTRAÇÕES}

\section{QUADROS}

Quadro 1: $\quad$ Produções científicas selecionadas

Quadro 2: $\quad$ Sistematização dos instrumentos de pesquisa

FIGURAS

Figura 1: $\quad$ Rabisco representando a complexidade da comunicação nas redes sociais. (Módulo Comunicação e Mobilização V)

Figura 2: Desenho representando a ideia de que para evitar o "ativismo de sofá" e promover a mobilização cidadã é necessário sensibilizar a pessoa. (Módulo Comunicação e Mobilização V)

Figura 3: Desenho representando a ideia de Camile da representação de um Diagrama de Venn (Módulo VI - DRP) 


\section{INTRODUÇÃO}

A educação não-formal tornou-se, desde o final dos anos 60 e início dos 70, parte do discurso político internacional de políticas em educação. Sua importância acentuou-se principalmente a partir de dois marcos. Em primeiro, o da conhecida análise sobre a "crise mundial da educação" (“The World Educational Crisis”; Coombs, 1968) que, em suas conclusões, revelou que os sistemas educacionais apresentavam uma lenta adaptação às mudanças sócio-econômicas em curso, exigindo que novos setores da sociedade se articulassem para enfrentar as novas demandas sociais com relação à educação. Em segundo, o documento da UNESCO de 1972 "Learning to Be - The Faure Report", que ao afirmar metas quanto à "educação ao longo da vida" (life long-education) e à "sociedade de aprendizagem" (learning society), expressa pela primeira vez o termo “educação não-formal”.

A crescente atenção à problemática educacional que transcende a educação formal, e que se constitui em contextos e aspectos profundamente diferenciados, fornece, assim, as bases para a tripartição do sistema educacional nas categorias conceituais da educação formal, nãoformal e informal e para a crescente utilização do termo educação não-formal como campo conceitual na literatura cientítica, a partir das décadas de 80 e 90. (GARCIA, 2005; LIMA; GONÇALVEZ DIAS, 2008)

No presente trabalho, utilizamos, para essas categorias, a conceitualização de Trilla (2008): a educação formal, hierarquicamente estruturada e cronologicamente graduada, chancelada pelo Estado, incluindo estudos acadêmicos, especializações e instituições de treinamento técnico e profissional; a educação não-formal: qualquer atividade organizada fora do sistema formal de educação, operando separadamente ou como parte de uma atividade mais ampla, que pretende servir a pessoas previamente identificados como aprendizes e que possui objetivos de aprendizagem; e a educação informal, processo em que o indivíduo adquire atitudes, valores, procedimentos e conhecimento a partir da experiência cotidiana e das influências educativas em seu meio social e cultural - na família, no trabalho, no lazer e nas diversas mídias de massa.

A título de ilustração, de forma geral, pode-se dizer que a educação formal está ligada a escolas e a instituições de treinamento; a não-formal, a ações de educação popular, comunitária, sindical, conduzidas por ONGs, por instituições religiosas, por iniciativas particulares, por museus e bibliotecas e em quaisquer outras organizações e instituições fora do sistema formal; 
e, por fim, a educação informal, ligada à aprendizagem espontânea por meio das relações sociais na interação com amigos, família, colegas de trabalho e nos processos de comunicação social em geral.

Não há consenso na diferenciação entre esses conceitos e autores se utilizam de diferentes critérios para delimitá-los. Na educação informal, é comumente evidenciada a ausência de intencionalidade pedagógica e de método. Em contraposição, na educação formal e não-formal, a intenção pedagógica e os objetivos de aprendizagem são explicitados. Ao mesmo tempo, na diferenciação entre o formal e o não-formal, são evidenciados determinantes tais como, a existência de um currículo homogêneo definido pelo Estado, de hierarquia na relação professor-aluno, de sistemas de avaliação de aprendizagem, de tempo de graduação, e certificação e diplomação. Os limites entre as três diferentes dimensões, no entanto, não são claros. Há, por exemplo, intencionalidade pedagógica, objetivos e método quando um pai ensina um filho a escovar os dentes. Visitas escolares a um museu, fazem uso, na educação formal, do espaço não-formal. Um congresso científico, por sua vez, pode possuir, ao mesmo tempo, aspectos tanto da educação formal quanto da informal. No desafio da diferenciação teórica entre os três conceitos, cabe às pesquisas na área delimitarem e apontarem os critérios utilizados para a categorização pretendida. ${ }^{1}$

Pensar a educação não-formal remete-nos, irremediavelmente, à reflexão sobre a historicidade da instituição formal, escolar, e no papel hegemônico que ela adquire na contemporaneidade como instituição ocupada com a transmissão e a construção de conhecimentos em nossa sociedade. (FERNÁNDEZ, 2006) Com efeito, a categoria da educação não-formal, emerge em estreita relação com o contexto formal, reivindicando, em sua pretensa oposição, uma independência. Para Garcia (2005, p. 31):

O conceito de educação não-formal, assim como outros que têm com ele ligação direta, habita um plano de imanência que não é o mesmo que habita o conceito de educação formal [...] A educação não-formal tem um território que lhe é próprio; assim, não é oportuno que sejam utilizados instrumentais e características do campo da educação formal para pensar e compreender a educação não-formal.

Por suas características de não ser obrigatória, estruturada, por não seguir currículos definidos, por partir das necessidades prementes do grupo social que participa da ação educativa, entre outras, a educação não-formal assume o potencial de um contexto educacional

\footnotetext{
${ }^{1}$ Notas de aula da disciplina "Educação em Contextos Não-formais e Informais" cursada no ano de 2011, sob docência da professora Maria Helena Carneiro, da Faculdade de Educação da Universidade de Brasília.
} 
efetivamente transformador, não ocupado com o ensino e a aprendizagem de conteúdos historicamente sistematizados, mas com processos permanentes associados à construção identitária do grupo social, à consciência e à organização de grupo, ao resgate de sentimento de valorização de indivíduos e do grupo, à aprendizagem política (GOHN, 2011). Parte-se, assim, de um conceito mais amplo de educação que, conforme proposição de Gohn (2011), está associada às formas culturais de ensino e aprendizagem ao longo da vida dos cidadãos; e da qual a educação escolar, formal, oficial, é abordada apenas como "uma das formas da educação". Para a autora,

A Educação não deve ser apenas uma agência, uma socialização de conhecimentos, mas deve contribuir para a formação de capacidades para atuar e pensar de forma criativa, inovadora, com liberdade. [...] Tal modelo exige uma escola social e culturalmente heterogênea e supõe a exclusão do modelo de escola homogênea; [...] [nesse modelo a escola é] definida por um forte elo de pertencimento, de sentimento de "nós". Pressupõe uma educação não mais voltada para a preparação genérica dos indivíduos para a sociedade mais ampla, ou voltada exclusivamente para a inserção econômica no mundo do trabalho como preconizam os modelos neoliberais -, mas exige uma preparação voltada para recompor a personalidade dos indivíduos, para que se convertam em seres capazes de encontrar e preservar a unidade de sua experiência por meio das emoções da vida e da força das paixões que se exerce sobre ela.

Para Garcia (2005), a possibilidade de se constituir de forma heterogênea, de privilegiar a diferença em detrimento da aprendizagem de conteúdos curriculares, de se utilizar de espaços e práticas pedagógicas diferenciadas, faz da educação não-formal uma dimensão privilegiada para a formação de cidadãos críticos e criativos.

Outra concepção considera a existência de um continuum conceitual que vai da educação formal a não-formal (ROGERS, 2004). Neste continuum, o autor coloca a aprendizagem e o aprendiz como o centro de todo o processo gerado pelos sistemas educacionais, propõe um novo paradigma em que a educação não-formal e a informal não são tomadas como categorias estanques. Por meio desse continuum, as instituições envolvidas em cada uma das categorias poderiam ser analisadas de forma integrada ou separada.

Analisar a educação não-formal sob a ótica da aprendizagem não consiste tarefa trivial dado o desafio da compreensão de um fenômeno tão complexo e multifacetado de aspectos cognitivos, afetivos, psicomotores, simbólicos, entre outros. Aprendemos a todo o momento, de diversas formas e em diferentes contextos: ao ler jornal, ao cozinhar, ao conversar com amigos, ao estudar para provas, ao visitar museus, etc. Aprendemos de forma intencional ou intuitiva, em situações espontâneas ou pedagogicamente mediadas. Aprendemos, ainda, de 
forma mais fluida e dinâmica do que imaginamos: retomamos aprendizagens passadas e as aprofundamos ou as re-significamos em diferentes momentos e contextos. Somos ainda capazes de "transferir" ou generalizar nossos aprendizados para situações inéditas e novos problemas. A cada momento e contexto específico de aprendizagem, diferentes processos psicológicos, tais como inteligência, criatividade, memória, motivação, atenção, entre outros, se constituem e se articulam de diferentes formas. Com efeito, aprendemos de diversas formas, em diversos contextos sociais, utilizando múltiplos recursos psicológicos e desenvolvendo variados processos mentais.

Consideramos, assim, "aprendizagens" em oposição à histórica tendência científica de compreensão do fenômeno "da aprendizagem" como único e uniformizado. Para Tunes, Tacca e Mitjáns Martínez (2006), essa tendência, potencializada pelas grandes teorias da aprendizagem, do final do século XIX e do século XX, acaba por limitar-se à compreensão de uma faceta específica do fenômeno, ou seja, de um tipo específico de aprendizagem, ainda que pretensamente se proponha à explicação da totalidade do fenômeno. Para as autoras, essas grandes teorias acabam por assumir uma perspectiva reducionista do fenômeno na medida em que, ainda que reconheçam uma formulação genérica sobre a aprendizagem, divergem sobre $o$ que ela efetivamente consiste e sobre a interpretação de como ela ocorre.

Tomando-a, de forma genérica, podemos arriscar considerar a aprendizagem como um processo de apropriação e produção de conhecimento, de formas de comportamento, valores, atitudes, habilidades que nos envolve em algum tipo de mudança. No entanto, efetivamente, como se dá esse processo e o que são essas mudanças são motivos de inconciliáveis divergências que refletem, necessariamente, diferentes concepções teóricas e epistemológicas. Por mera ilustração, podemos citar as teorias inatistas que, a partir do idealismo platônico, advogam a irrelevância da aprendizagem como processo de desenvolvimento psicológico na medida em que há uma preparatoriedade humana advinda de estruturas inatas. Podemos citar as teorias comportamentalistas que, a partir do empiricismo associacionista, moderno, tomam o conhecimento como reflexo e a aprendizagem como processo mecânico de aquisição de hábitos. Citamos as teorias construtivistas, nas quais a aprendizagem é um processo de assimilação e reestruturação cognitiva, tendo como resultados mudanças nas estruturas cognitivas da mente. E ainda, a abordagem histórico-cultural que compreende a aprendizagem como processos de apropriação de formas culturais, signos, símbolos e valores que integram o homem em um contexto sócio-histórico e permitem seu desenvolvimento (POZO, 2002; 
NUNES e SILVEIRA, 2009). Não cabe, ao escopo da presente pesquisa, discorrer sobre as diferentes concepções teóricas sobre o fenômeno da aprendizagem; citamo-nas apenas para frisar a ênfase que cada uma delas atribui a facetas específicas desse fenômeno.

Em conformidade com Tunes, Tacca e Mitjáns Martínez (2006), reconhecemos que a pesquisa sobre aprendizagem não deve se pautar na busca por sua definição última ou por um princípio universal que a regeria, mas precisamente pelo que permita a compreensão do que a possibilita tão diversa e plural.

As autoras lembram ainda que não há novidade em considerar as múltiplas formas de expressão da aprendizagem pois já Vigotski, em Fundamentos da Defectologia de1924, ao estabelecer a clara relação entre desenvolvimento e aprendizagem e ao afirmar a diversidade das formas de desenvolvimento, admite como premissa, o fato da diversidade na aprendizagem.

Para ele [Vigotski], a aprendizagem humana é um fenômeno cultural historicamente condicionado pelas condições concretas de vida e, por isso mesmo, com enorme amplitude de variação em suas formas de manifestação. (TUNES, TACCA e MITJÁNS MARTÍNEZ, 2006, p. 116)

Com efeito, mesmo que sob diferentes linhas teóricas, o pensamento contemporâneo sobre aprendizagem já assume a enorme diversidade de seus processos. Sob a perspectiva teórica do construtivismo cognitivista, Pozo (2002) aponta que a diversidade da aprendizagem relaciona-se ao fato de que forma e conteúdo não são dissociáveis, i.e. o que aprendemos relaciona-se diretamente com a forma com que aprendemos. Dessa maneira, nos contextos de mudanças sociais, novas demandas educacionais pressionam, permanentemente, por novas formas de aprender. Sob outras perspectivas teóricas mais relacionadas à psicologia cultural, expressas nos trabalhos de Bruner, Cole e Weschler, os processos de aprendizagem e desenvolvimento devem ser compreendidos como processos constituídos a partir da articulação de uma grande complexidade de elementos os quais envolvem fatores ligados às singularidades da constituição pessoal, das interações e dos contextos sócio-culturais (REGO, 2011).

Na presente pesquisa, assumimos a aprendizagem sob a perspectiva da subjetividade desenvolvida sob um marco histórico-cultural. Busca-se, sob essa perspectiva, a compreensão dos processos de aprendizagem enquanto processos da subjetividade do aprendiz, na sua simultânea condição de subjetividade individual e social, conforme a define González Rey 
(1997, 2001, 2005a, 2005c, 2006). ${ }^{2}$ Considera-se o aprendiz enquanto indivíduo concreto, produtor de sentidos subjetivos que, como produções simbólico-emocionais, se constituem, ao mesmo tempo históricas, em relação a experiências vividas na trajetória de vida, e atuais em relação a sua interação nos espaços sociais em que aprende (GONZÁLEZ REY, 1997, 2001, 2005a, 2005c, 2006). Assumir a condição subjetiva do aprendiz implica reconhecer a integralidade do sistema psíquico deste indivíduo que pensa, sente e se auto-organiza por meio de sua produção subjetiva no decorrer do processo de aprender. Implica compreender o pensamento e a construção do conhecimento como processos de produção subjetiva que, para além da assimilação cognitiva ou da apropriação de significados culturais, conferem o caráter construtivo-criativo do sujeito que aprende em processos de personalização do conhecimento e a geração de ideias. (GONZÁLEZ REY, 2005, 2009b, 2012).

Com base nessa perspectiva teórica da aprendizagem como processo da subjetividade humana, interessa-nos a linha teórica que desenvolve estudos sobre um tipo específico de aprendizagem: a aprendizagem criativa, conforme elaborada por Mitjáns Martínez (1997, 2000, 2004, 2006, 2009a, 2012a).

A aprendizagem criativa se refere a um tipo complexo de aprendizagem, diferenciada, por exemplo de tipos mais simples como a aprendizagem mecânica ou a reprodutiva. Ou tão somente a aprendizagem compreensiva. Para Mitjáns Martínez, ela se caracteriza pela personalização da informação, pela autonomia do aprendiz frente ao dado e geração de ideias novas, transcendendo o que está posto.

Sob a perspectiva histórico-cultural da subjetividade, assume-se que a aprendizagem criativa, longe de ser entendida como potencialidade inata do aprendiz, configura-se como uma expressão do sistema subjetivo do aprendiz e se constitui em sua história de vida e nos contextos sócio-culturais e relacionais em que este aprendiz se desenvolve.

Reconhece-se que esse tipo de aprendizagem é pouco encontrado e/ou estimulado nos diversos contextos educacionais, em especial no contexto escolar. (MITJÁNS MARTíNEZ, 2002, 2008a, 2008b, 2009b; AMARAL e MITJÁNS MARTÍNEZ, 2009). Não obstante, Mitjáns Martínez defende que, por consistir uma aprendizagem qualitativamente diferenciada tendo em vista a produção criativa e a mobilização subjetiva que a caracteriza, a aprendizagem

\footnotetext{
${ }^{2}$ Informações mais aprofundadas sobre a Teoria da Subjetividade serão apresentadas no capítulo II deste projeto.
} 
criativa deveria ser priorizada por no mínimo duas razões: (1) a estabilidade do aprendido e as possibilidades de sua "transferência" para novos contextos; (2) o seu potencial como unidade de desenvolvimento da condição de sujeito no processo de aprender ou em alguma atividade que o aprendiz desenvolva (MITJÁNS MARTÍNEZ, 2012b).

Ressalta-se que a aprendizagem criativa, como categoria explicativa, encontra-se em processo de desenvolvimento teórico, e as pesquisas, até então, têm privilegiado a compreensão de sua expressão no contexto escolar, formal (MITJÁNS MARTÍNEZ, 1997, 2002, 2008a, 2009b, 2012a, 2012b; AMARAL, 2011; OLIVEIRA, 2010). Em continuidade e avançando na compreensão deste tipo de aprendizagem, a presente pesquisa buscará analisar a aprendizagem criativa em contextos não-formais, partindo de questões como: qual o papel de espaços sociais na aprendizagem? Como se expressa a aprendizagem criativa no contexto não-formal? Como o aprendizado criativo no contexto não-formal, é "retomado" em outros contextos?

De forma a abordar essas temáticas, a pesquisa examinará a literatura na área de aprendizagem em contextos não-formais, mais especificamente a de aprendizagem em museus. Apesar da ampla produção acadêmica sobre educação não-formal como associada a processos de ensino e aprendizagem em movimentos de base, na educação comunitária, na educação sindical, ou em organizações não governamentais e na sociedade civil organizada (GOHN, 2011), nossa opção pelo arcabouço teórico da aprendizagem em museus decorre do fato de a pesquisa considerar, em seu estudo de campo, a análise de uma ação educativa originalmente proposta e desenvolvida por uma instituição museal. Esta ação educativa consistia um projeto de divulgação científica que desenvolvia uma série de atividades em torno de temáticas relacionadas à saúde nas escolas e mobilização social, e que tinha duração de 12 meses.

Estudos na área de aprendizagem em museus destacam, como aspectos que caracterizam a aprendizagem nesse contexto, o voluntarismo, a automotivação, a livre-escolha, a ludicidade e o apelo à emocionalidade (SCHAUBLE, LEIDNHARDT e MARTIN, 1997; FALK, 1999; FALK e DIERKING, 2000). As pesquisas na área, embora evidenciem a ocorrência da aprendizagem, deparam-se com a enorme dificuldade de acessar exatamente $o$ que é aprendido nesses locais. Segundo Falk (2000), elas têm historicamente privilegiado a compreensão da aprendizagem em museus em termos de ganhos cognitivos, aos moldes da aprendizagem escolar e têm falhado em não considerar a aprendizagem em tempos diferenciados e em não garantir o acesso mais profundo à compreensão dos indivíduos envolvidos. 
Para o autor (2004), há que se considerar que as pessoas se constituem de múltiplas histórias; que produzem sentidos diferenciados sobre uma mesma memória; que a motivação e a identidade do aprendiz são contextuais; e, por fim, que o que se aprende hoje depende enormemente do que se aprendeu ontem e de como isso será eventualmente interpretado em ocasiões futuras. A partir das ideias de Falk, há uma percepção na área sobre a necessidade de pesquisas que busquem compreender a experiência museal em conexão com a vida integral dos indivíduos (FALK, 2000; FALK, 2004; RENNIE, 2004; BIZERRA e MARANDINO, 2009).

Acreditamos que a presente pesquisa, ao buscar compreender os aspectos constitutivos da aprendizagem criativa no contexto não-formal, se alinha a essas ideias na medida em que, com base no arcabouço teórico da subjetividade na perspectiva histórico-cultural, toma como ponto de partida a compreensão da constituição subjetiva dos aprendizes na ação educativa em um contexto não-formal. Conforme já ressaltado, assumimos que a produção subjetiva da ação do aprender é, ao mesmo tempo, histórica e atual sendo, portanto, singular ao indivíduo a partir da forma como esse subjetiva suas experiências em sua trajetória de vida. (GONZÁLEZ REY, 2008)

Ao buscar compreender o papel do contexto social na organização subjetiva do aprendiz, a pesquisa assume o caráter social da aprendizagem e reconhece que este social se expressa de múltiplas formas, desde a natureza dos conteúdos e habilidades a serem aprendidos, até as posições diferenciadas que o aprendiz ocupa na situação pedagógica (relação com professores, monitores do museu, colegas,...), a emocionalidade que caracteriza cada um dos espaços de aprendizagem, as relações com o outro no processo de aprendizagem, entre outros (TUNES, TACCA e MITJÁNS MARTíNEZ, 2006). Consideramos que cada uma dessas expressões se apresenta de forma diversa em diferentes contextos de aprendizagem, formal e não-formal. Não obstante, o papel de diferentes contextos nos processos do aprender, para além do contexto formal, não tem consistido foco de estudos nas pesquisas sob essa abordagem teórica.

É importante ainda ressaltar minha experiência como colaboradora, durante três anos, na ação educativa similar à analisada pela presente pesquisa, também orientada à divulgação e comunicação científica. Originalmente iniciada por uma instituição museal, no Rio de Janeiro, esta ação educativa foi implementada, desde 2004, também em Brasília. Por ocasião deste trabalho na ação educativa, que tinha objetivos similares com relação de reflexão crítica sobre saúde e sobre o papel da ciência na sociedade, tive contato com alunos que foram intensamente impactados, demonstrando um forte envolvimento emocional com a experiência e 
desenvolvendo, em decorrência dela, posturas e atitudes frente à aprendizagem e a ações práticas nas áreas do projeto. Posturas e atitudes tais como a conscientização sobre comida, sobre a produção e a reciclagem de lixo, fundação de ONGs; a opção pela carreira científica ligada a ciências naturais, entre outras.

Tendo em vista todo o exposto, nossa reflexão de partida nos permitiu a elaboração de algumas hipóteses interpretativas iniciais para a nossa construção teórica ${ }^{3}$. A primeira hipótese consistia no reconhecimento de que diferentes contextos de aprendizagem, formais e nãoformais, se apresentam ambos como espaços sociais subjetivados pelo aprendiz e, nesse sentido, podem favorecer ou prejudicar os processos de aprendizagem criativa. Em decorrência dessa primeira hipótese, a segunda hipótese se referia ao nosso entendimento de que a aprendizagem criativa no contexto não-formal, pela produção criativa e pela mobilização subjetiva que a caracterizam, impacta a subjetividade de forma a promover a emergência do aprendido em outros contextos. A terceira hipótese, por fim, relacionava-se à consideração de que, pelas características próprias de contextos não-formais de aprendizagem, tais como o voluntarismo, o apelo à ludicidade, a autonomia de escolha sobre o que aprender e em que ritmo, a ausência de processos avaliativos, entre outros, as formas de expressão e os processos subjetivos constitutivos da aprendizagem criativa, no contexto não-formal, consistir-se-iam diferenciadas das até então estudadas nos contextos formais.

Considerando essas hipóteses teóricas iniciais, o objetivo geral da pesquisa é compreender a configuração subjetiva da ação do aprender e formas de expressão da aprendizagem criativa em um contexto de educação não-formal.

O presente trabalho está organizado em cinco capítulos. O Capítulo I apresenta uma análise da produção científica na área de aprendizagem em museus. O Capítulo II apresenta o arcabouço teórico central da Teoria da Subjetividade e discorre sobre a criatividade e a aprendizagem criativa, a partir deste referencial teórico, de forma a subsidiar as reflexões que envolvem a aprendizagem criativa em contextos não-formais. O Capítulo III informa o percurso

\footnotetext{
${ }^{3}$ Esclarecemos aqui que o termo hipótese interpretativa busca diferenciação do significado de hipótese de pesquisa, tradicionalmente utilizado por diferentes abordagens metodológicas, tanto quantitativas quanto qualitativas. Com base na Epistemologia Qualitativa, proposta metodológica utilizada por esta pesquisa e apresentada no capítulo III, a hipótese não reflete as possíveis relações lógicas com um determinado problema identificado de forma independente do processo de elaboração teórica do pesquisador. As hipóteses interpretativas consistem, em si, as primeiras construções teóricas do pesquisador, a partir das quais ele conduzirá seu modelo teórico. (GONZÁLEZ REY, 2005b)
} 
metodológico da pesquisa, de base qualitativa e fundamentada nas contribuições da Epistemologia Qualitativa de González Rey, como base para as análises e construções teóricas da pesquisa. O Capítulo IV, finalmente, apresenta nossas análises interpretativas dos estudos de caso, sendo seguido pelas considerações finais. 


\section{CAPÍTULO I: PESQUISAS SOBRE APRENDIZAGEM NO CONTEXTO NÃO-FORMAL: O CASO EXEMPLAR DA APRENDIZAGEM EM MUSEUS}

Museus são instituições hoje percebidas como espaços de permanente diálogo para significação e re-significação do patrimônio cultural de grupos sociais. ${ }^{4}$ Comumente considerados instituições de educação não-formal, a aprendizagem em museus, de maneira diferenciada à aprendizagem escolar, caracteriza-se por fatores como: a relação com o objeto museal e o ambiente físico, o voluntarismo; a ludicidade, a multisensorialidade e o apelo à emocionalidade; a autonomia de escolha do aprendente sobre o que aprender e em que ritmo, a não sequencialidade, entre outros. Com relação à educação em museus destaca-se a maior liberdade de seleção e organização de conteúdos, que podem ser tratados de forma interdisciplinar e contextualizada à realidade do aprendiz; a ausência de processos avaliativos, e o desejo, em decorrência dos preceitos da educação patrimonial, por uma educação que permita aos sujeitos envolvidos transcenderem os dados e informações expostas de forma a adquirirem uma postura crítica e criativa sobre as temáticas museais. (ALMEIDA, 1997)

Segundo Falk e Dierking (1992), a pesquisa sobre a aprendizagem, em contextos nãoformais, em especial em museus, ganhou força a partir da década de 80. Desenvolveu-se, desde então, em diversas áreas tais como: o planejamento e a comunicação expositiva (HOOPER GREENHILL, 1994; MARANDINO, 2003), o processo de aprendizagem do visitante, centrando-se nos seus conhecimentos prévios e conhecimentos adquiridos (ANDERSON; LUCAS; GINNS, 2003; FALK; ADELMAN, 2003; RENNIE; JOHNSTON, 2004), e interações sociais na aprendizagem museal, ou seja, conversações e mediações entre grupos familiares, monitores, grupos externos (GASPAR,1993; PORTO, 2008; SÁPIRAS, 2007).

No entanto, apesar do aumento das pesquisas e do crescente interesse na compreensão e na caracterização da aprendizagem em museus, percebe-se ainda, nas pesquisas da área, uma grande ênfase nos comportamentos e interações sociais ocorridos durante a visita. Os estudos

\footnotetext{
${ }^{4}$ Cabe notar que consideramos, para a pesquisa, uma compreensão mais ampliada da instituição museal tomando-a como toda e qualquer instituição que se ocupa com a pesquisa, a preservação e a divulgação de patrimônios culturais e naturais, conforme definição do Comitê Internacional de Museus (ICOM), aprovada pela 20ạ Assembléia Geral, em 2001. Nesse sentido, em tipologias diversas, podem ser considerados "museus", instituições tais como parques naturais, jardins botânicos, centros culturais, centros de ciências, planetários, sítios naturais ou arqueológicos, ou "qualquer outra instituição que reúna algumas ou todas as características do museu, ou que ofereça aos museus e aos profissionais de museus os meios para realizar pesquisas nos campos da Museologia, da Educação ou da Formação", entre outros (IBRAM, 2013).
} 
têm falhado em não considerar a influência da aprendizagem museal em momentos diferenciados da vida do indivíduo e em não garantir o acesso mais profundo à compreensão dos indivíduos envolvidos. (FALK, 2000; FALK, 2004)

Conforme apontam alguns pesquisadores, há a percepção crescente da necessidade de pesquisas que busquem compreender os indivíduos em profundidade. Pesquisas mais horizontais que entendam a experiência museal em conexão com a vida integral dos sujeitos. Ou seja, pesquisas que investiguem o impacto da experiência museal, considerando sujeitos constituídos em contextos anteriores e posteriores ao contexto museal em si (BIZERRA; MARANDINO, 2009; FALK, 2004; RENNIE; JOHNSTON, 2004).

Em concordância com essa percepção, este capítulo apresentará, em um primeiro momento, uma revisão da produção científica na área da aprendizagem em museus, tendo em vista diferentes enfoques metodológicos sobre aprendizagem, comentando-os à luz de nossa opção teórica da aprendizagem como processo da subjetividade humana. Em um segundo momento, apresentaremos pesquisas relacionadas ao tema de identidade de aprendizagem na experiência museal por sua aproximação com a nossa perspectiva no que concerne à relevância da compreensão da constituição subjetiva na aprendizagem em museus. Por fim, discutiremos aspectos das inter-relações das aprendizagens no museu e na escola, levantados em pesquisas da área, sob a perspectiva da subjetividade.

Para a revisão da produção científica na área de aprendizagem em museus, foram realizadas consultas nos bancos de dados Dedalus (Biblioteca Virtual da Universidade de São Paulo), na Biblioteca Digital Brasileira de Teses e Dissertações (BDTD), do Ministério da Ciência, Tecnologia e Inovação, e no banco de periódicos da Coordenação de Aperfeiçoamento de Pessoal de Nível Superior (Capes), do Ministério da Educação. Consultou-se ainda a Base de Dados do Grupo de Estudo e Pesquisa em Educação Não-formal e Divulgação em Ciência - GEENF.

Com base nas palavras-chaves "aprendizagem em museus" e "educação em museus", "aprendizagem não-formal”, "museu escola", o seguinte conjunto de obras foi selecionado: 10 teses e dissertações, 7 artigos científicos e 5 livros. Além das consultas às bases de dados, foram selecionados artigos nos seguintes periódicos nacionais: História, Ciências, Saúde Manguinhos (3) e na Revista Brasileira de Educação (1). Totalizando 4 artigos. Dois critérios foram utilizados na seleção das obras, publicações após a década de 90 e trabalhos que 
apresentassem estudos de avaliação aprendizagem de grupos escolares ou não escolares, com referência expressa à concepção teórica e metodológica utilizada. Nessa perspectiva, não foram considerados estudos de públicos, de comunicação expositiva, organização expográfica, entre outros.

A produção internacional foi selecionada a partir das bases de dados Wiley Online Library e JStor. Foram selecionados artigos científicos dos seguintes periódicos internacionais: Curator: The Museum Journal (2 artigos), Journal of Research in Science Teaching (3 artigos), Science Education (4 artigos), Journal of Science Education and Technology (1 artigo), Journal of Museum Education (5 artigos), Open Museum Journal (1 artigo), Daedalus - MIT Press (1 artigo), e da base de dados do The Encyclopaedia of Informal Education - Infed (1 artigo). Resultando um total de 18 artigos.

A presente análise selecionou, dessa forma, o seguinte total de obras:

\begin{tabular}{|l|l|l|}
\hline \multirow{2}{*}{} & \multicolumn{2}{|c|}{ Números de Produções } \\
\cline { 2 - 3 } & Nacionais & Internacionais \\
\hline Teses e dissertações & 10 & 18 \\
\hline Artigos científicos & 11 & 5 \\
\hline Livros & \multicolumn{2}{|c|}{} \\
\hline \multicolumn{2}{|c|}{ Quadro 1: Produções científicas selecionadas }
\end{tabular}

\subsection{Revisão da produção científica sobre aprendizagem em museus}

Em trabalho entitulado “A Concepção de Aprendizagem nas Pesquisas em Educação em Museus de Ciências", Bizerra e Marandino (2009), realizam uma extensa revisão bibliográfica, identificando as concepções e arcabouços teóricos na área. As autoras levantaram 145 trabalhos, sendo a maioria, de 71,3\%, artigos de periódicos científicos; $20,7 \%$, livros e capítulos de livros, e, em número mais reduzido dissertações e teses sobre o tema. A maioria das publicações aparece após 1995. Segundo as pesquisadoras, os dados refletem o aumento considerável, na última década, de pesquisas sobre aprendizagem em museus, repetidamente citado por diversos autores. Com efeito, alguns autores apontam que, apesar desse recente aumento, as pesquisas na área encontram-se ainda em um estado formativo (ANDERSON ET AL, 2003; FALK, J., 2007).

Bizerra e Marandino concluem que a maioria dos trabalhos tende, atualmente, a conceber a aprendizagem como um processo, ao invés de um produto, mas apontam que as 
diferentes correntes teóricas na literatura da aprendizagem em museus tendem a divergir na forma como ela acontece. Enquanto uns a vêem como um processo eminentemente mental, focado no indivíduo aprendente, outros a vêem como um processo eminentemente social.

As autoras dividem as obras analisadas em três principais arcabouços teóricos: o construtivismo, a teoria sociocultural e o Modelo Contextual. Optamos por adaptar as três categorias levantadas pelas autoras, incluindo a Teoria da Atividade, conforme originalmente desenvolvida por Leontiev, como uma terceira perspectiva teórica em separado, em razão de ser esta a corrente teórica da abordagem histórico-cultural de maior representatividade nos estudos brasileiros. A seguir, comentamos as obras e suas respectivas abordagens teóricas à luz dos estudos das ideias da aprendizagem como processo da subjetividade.

\subsubsection{Pesquisas de bases construtivistas}

A partir de contribuições do pensamento de Piaget, o construtivismo constituiu-se em uma linha pedagógica ou um referencial de ideias teóricas que tem sua ênfase na capacidade ativa do aprendente em adquirir conhecimento e desenvolver-se mentalmente. De forma crítica às teorias empiristas e inatistas, Piaget concebe o desenvolvimento mental como um processo sucessivo de construção de estruturas mentais, resultante da ação humana associada a processos de equilibração cognitiva. (PIAGET, 1986)

Em sua obra Learning in the museum, Hein (1998) propõe o enfoque construtivista para a aprendizagem em museus, sugerindo uma série de princípios que emergiram do pensamento construtivista:

- a aprendizagem é um processo ativo de construção de significado a partir de inputs sensoriais;

- quando pessoas aprendem, elas aprendem sobre o processo de aprendizagem, assim como aprendem o conteúdo;

- a aprendizagem acontece na mente;

- a linguagem e a aprendizagem estão indissociavelmente relacionadas;

- a aprendizagem é uma atividade social e acontece com outros;

- a aprendizagem é contextual, na medida em que aprendemos com o que já conhecemos, nossas crenças e discriminações;

- o conhecimento prévio é um pré-requisito para a aprendizagem; 
- aprendizagem acontece em longos períodos de tempo, a partir da exposição e pensamentos repetidos;

- a motivação é essencial para a aprendizagem.

As pesquisas sobre a aprendizagem em museus a partir da teoria construtivista emergem com mais vigor a partir da década de 80 , em contraposição às pesquisas da década anterior, caracterizadas predominantemente por estudos de públicos que, por meio de metodologias quantitativas, associavam diretamente a aprendizagem ao comportamento no decorrer da visita. (SÁPIRAS, 2007, MARANDINO, 2009) A abordagem construtivista aporta uma enorme contribuição às pesquisas na área por buscar entender aspectos constitutivos da aprendizagem, compreendendo-a no interjogo de fatores cognitivos, afetivos, pessoais e de desenvolvimento de capacidades (físicas e mentais).

Com base na abordagem construtivista, Silva (1999) avalia a aprendizagem na compreensão de modelos científicos relacionados à astronomia, a partir de padrões de comportamento entre os visitantes e os objetos expostos. Utilizando-se de uma metodologia de memória estimulada, sua pesquisa aplica questionários antes e após a visita e conclui que, na análise dos padrões encontrados, considerando diferentes níveis de interação com o objeto, com pessoas e com a informação escrita exposta, evidencia-se aprendizagens na interpretação dos modelos científicos.

Rocha, Lemos e Schall (2010) desenvolvem uma pesquisa a partir do arcabouço teórico da aprendizagem significativa de Ausubel, por meio da qual buscam analisar e descrever resultados de um projeto educativo no museu, referentes à aprendizagem de conteúdos que permitam concepções mais amplas sobre saúde. Por meio de entrevistas semi-estruturadas e abertas, antes e após a visita, a pesquisa conclui, a partir das percepções dos alunos, que a participação no projeto favoreceu a captação de significados sobre a história da saúde, a compreensão da relação entre saúde e ambiente, da ciência como produção humana e do papel do cientista na sociedade.

Por fim, ainda na abordagem construtivista, Anderson, Lucas e Ginns (2003) analisam a construção de conhecimento durante uma visita a uma exposição de ciências a partir do uso de mapas mentais e entrevistas semiestruturadas antes e após a visita. Em suas análises, 
evidenciam que os ganhos cognitivos podem resultar em simples assimilações ou em substancial (re)estruturação da estrutura cognitiva prévia.

Ainda que de grande valor para a compreensão mais profunda do aprendizado nas experiências museais, percebe-se que as pesquisas de abordagem construtivista tendem a focar a aprendizagem como processos de mudanças nas pré-concepções e nas aquisições cognitivas a partir da aprendizagem de conteúdos temáticos. Em nosso entendimento, as pesquisas nesta abordagem, tendem a desconsiderar aspectos mais subjetivos do visitante como relevantes no processo de aprendizagem. Conforme Louis Silverman (1995 apud KELLY, 2002, pg. 10, tradução nossa) coloca,

[...] um dos grandes desafios para o construtivismo consiste as formas mais pessoais e subjetivas com as quais os visitantes constroem significados (tais como suas experiências de vida, opiniões, imaginação, memórias e fantasias); elas são praticamente ignoradas ou muito frequentemente invalidadas em museus, onde tendem a ser consideradas pelos monitores como ingênuas e inapropriadas.

De forma diferenciada da abordagem construtivista, em nossa compreensão, processos de aprendizagem não ocorrem em separado de um sistema psíquico integral que tem, no interjogo entre o simbólico e o emocional, sua dimensão constitutiva. Aprender é, portanto, uma expressão deste sistema por meio do qual o aprendiz pensa, sente e se auto-organiza em meio a sua produção subjetiva no decorrer da atividade de aprender.

A perspectiva da subjetividade, ao assumir o subjetivo, tomado como essa união indissociável entre o simbólico e o emocional, reconhece o papel central das emoções nos processos da psique humana. Ao considerá-la como permanente geradora de produções simbólico-emocionais, parte-se da ideia de que processos de pensamento e a construção do conhecimento, para além de processos de assimilação cognitiva, são processos de produção subjetiva (GONZÁLEZ REY, 2005, 2009, 2012).

\subsubsection{A Teoria Sociocultural}

A teoria sociocultural corresponde a um arcabouço teórico que, a partir da disseminação do pensamento de Vigotski em B. Rogof, J. Werstch (BIZERRA; MARANDINO, 2009; GONZÁLEZ, 2005), propõe que a aprendizagem é um processo socialmente mediado, que não 
acontece apenas dentro da mente do aprendente, mas é moldado pelo contexto, pela cultura e pelas ferramentas disponíveis na situação de aprendizagem.

Em 1997, Schauble, Leinhardt e Martin publicaram um artigo largamente influente sobre a conveniência do enfoque sociocultural para as pesquisas em aprendizagem em museus, enquanto instituições ocupadas com a significação e re-significação de patrimônios culturais e naturais. Para os autores, a aprendizagem em museus envolve a produção de significados dentro de um contexto social; sua compreensão abrange o interjogo entre os indivíduos agindo no contexto social, tomando-se conteúdos simbólicos e sígnicos como mediadores nesse contexto. No artigo, os autores apontam para o fato de que em museus, o "tratamento" dado a cada visitante é único, pois museus permitem livre escolha e variabilidade de aprendizagem, ao invés do domínio de um currículo. E mais, os efeitos da aprendizagem em museus podem ter um ciclo longo de tempo, emergindo anos após o momento da visita. Segundo os autores (SCHAUBLE; LEINHARDT; MARTIN, 1997, p. 4, tradução nossa),

A teoria sociocultural fundamenta-se em significados, não só comportamento. Museus são espaços de signos, artefatos culturalmente significativos, ferramentas e atividades. Aprender envolve a criação de significados e é difícil pensar em instituições que mais valorizam tal concepção de aprendizagem do que museus.

A teoria sociocultural recebeu uma ampla receptividade em um grande número de pesquisas que enfatizam a importância da construção social do conhecimento, da mediação e dos processos de construção de significados. No Brasil, vale citar os trabalhos de Gaspar (2003), Sápiras (2007), Porto (2008) e Bizerra (2009).

Gaspar (2003) faz uma análise das interações, ocorridas entre grupos escolares e monitores, no ambiente expositivo, a partir das idéias de Vigotski de zona de desenvolvimento proximal e de desenvolvimento de conceitos científicos. $\mathrm{O}$ autor faz uso de entrevistas antes e após a visita; e utiliza-se também do recurso de filmagem das entrevistas e visitas. Em suas conclusões, ressalta que o museu tem seu papel no processo gradual de interiorização dos conceitos, considerando as fases de conhecimento comum, pseudoconhecimento, e conhecimento científico. Defende que o monitor tem a oportunidade de atuar na zona de desenvolvimento proximal, mas deve estar capacitado para interpretar e compreender a condição de desenvolvimento dos alunos. 
Sápiras (2007) analisa as interações conversacionais em um contexto expositivo a partir de um conjunto de categorias de análises de conversas, levantadas por Allen (2002). São as categorias: as conversas conceituais, perceptiva, estratégica, afetiva e conectiva. A autora faz uso de observações, filmagens e entrevistas a grupos escolares. A partir de uma análise quantitativa das categorias, ela nota que as conversas conceituais predominam e que, para tal, é relevante o papel do monitor.

Porto (2008), em sua tese de mestrado, avalia o impacto de uma exposição na motivação de alunos para a aprendizagem de conceitos de física ótica, a partir das interações ocorridas durante e após o momento da visita. Conclui que a exposição e as mediações ocorridas na experiência contribuem significativamente para a motivação para a aprendizagem.

Para Bizerra e Marandino (2009), as abordagens socioconstrutivistas constituem, atualmente, as mais promissoras linhas de pesquisa na medida em que contemplam o caráter multifacetado do processo de aprendizagem e convidam a novas concepções de avaliação de aprendizagem, diferenciada da avaliação escolar. Em concordância com as autoras, entendemos que essa opção teórica representou uma grande contribuição para uma compreensão mais aprofundada dos processos de construção de significados pessoais e dos aspectos relacionais e afetivos envolvidos nas interações humanas em contextos museais. Sem dúvida, assemelha-se mais com a nossa abordagem teórica no que concerne à ênfase da dimensão do social nos processos do aprender. Não obstante, em nosso entendimento, as pesquisas sob essa abordagem, ao focarem precisamente processos de significação e re-significação simbólica tendem a privilegiar as interações e as práticas discursivas no contexto museal, tomando-as como uma instância em si, independente e em separado, dos processos emocionais e da condição singular do indivíduo que aprende. Tal problemática nos remete à distinção entre sentido e significado, que constitui central à diferenciação entre as teorias sociocultural e histórico-cultural. ${ }^{5}$

\subsubsection{A Teoria da Atividade, a partir da perspectiva histórico-cultural}

Como uma expressão da abordagem histórico-cultural ${ }^{6}$, a Teoria da Atividade,

\footnotetext{
${ }^{5}$ Aprofundaremos das diferenciações entre os enfoques sociocultural e histórico-cultural, no capítulo II, onde apresentamos o arcabouço teórico central de nosso estudo.

6 Por compartilharem alguns princípios teóricos centrais, Bizerra classificou sua abordagem teórica como sociocultural. Classificamos, no entanto, a Teoria da Atividade como abordagem histórico-cultural, optando por uma diferenciação baseada nos diferentes desdobramentos e interpretações do pensamento de Vigostki no decorrer do século passado. (GONZÁLEZ REY, 2005)
} 
desenvolvida a partir da obra de A.N. Leontiev (1903-1979) como um desdobramento do pensamento de L.S. Vigotski (1896-1934) e de S.L.Rubinstein (1889-1960), assume a organização psíquica como um sistema complexo, organizado na relação do indivíduo concreto em sua atividade sobre o meio. Diferencia-se, assim, da abordagem sociocultural por compreender os processos psíquicos relacionados à aprendizagem, como resultantes de uma formação mais complexa e integral da psique humana, decorrente da atribuição de sentido, que integra a motivação à palavra, no contexto da atividade; para além da simples apropriação de significados. ${ }^{7}$

De especial relevância para nossa pesquisa é o trabalho de Bizerra (2009) que desenvolve um grande estudo de análise da aprendizagem em museus sob a ótica da Teoria da Atividade. Partindo arcabouço teórico de Vigotski, Leontiev e Davidov, sobre a conformação da psique na atividade humana, a autora diferencia "aprendizagem" de "atividade de aprendizagem”, em que esta última se caracteriza, no âmbito da pesquisa, pela “[...] assimilação dos procedimentos generalizados de ação na esfera dos conceitos científicos e pelas mudanças no desenvolvimento psíquico das crianças” (BIZERRA, 2009, p. 75). Bizerra (2009, p. 81) analisa as interações de aprendizagem entre visitantes, monitores e objetos museológicos, como microciclos de processos de análise, síntese e modo de ação geral, onde o conhecimento teórico é assimilado, em um movimento de "ascenção do abstrato para o concreto". O arcabouço teórico utilizado pela autora permite a análise das tensões e contradições que movimentam a atividade de aprendizagem até a transformação dos conflitos em solução. Nesse sentido, a pesquisa vai além da simples identificação das categorias conversacionais de Allen (2002) como indícios em si de aprendizagem. Para a autora, as categorias de Allen (2002) permitem compreender "o que" e “o quanto" é aprendido, mas não “o como" (BIZERRA, 2009).

Bizerra se utiliza do conceito de microciclo de aprendizagem conforme proposto por Engestroom (apud BIZERRA, 2009). A partir das ideias de Davidov sobre a formação de conceitos, Engestroom realiza uma adaptação do modelo de Davidov de forma a considerar contextos de aprendizagem para além da sala de aula. Para Engestroom, as ações de

\footnotetext{
${ }^{7}$ Concebida a partir da abordagem histórico-cultural soviética, a Teoria da Atividade, conforme proposta por Leontiev, assume que a atividade humana diferencia-se da animal por ser resultante da consciência intencional para a satisfação de necessidades humanas. O conceito de atividade adquire, assim, a função de princípio explicativo para a constituição das funções psíquicas. Para Leontiev, a atividade humana desenvolve-se em interação dinâmica com a situação objetal composta por elementos tais como as necessidades ou motivos, os objetivos das ações e as condições de operação. (RIGON et al, 2012)
} 
aprendizagem de um microciclo consistem no questionamento, na análise, na modelagem, no exame do modelo, na implementação do modelo, na reflexão e na consolidação da nova prática (BIZERRA, 2009). Em sua pesquisa, Bizerra faz uso de entrevistas semi-estruturadas, e registros em áudio e vídeo, das interações entre famílias visitantes e monitores do Museu Biológico do Instituto Butantan. Entre suas conclusões, aponta que, entre as interações identificadas, muito embora várias consistiriam indícios de aprendizagem sob a perspectiva das categorias conversacionais de Allen (2002), apenas um subconjunto dessas se conformava como atividades de aprendizagem conforme a definição utilizada em sua pesquisa. Conforme Bizerra coloca (2009, pg.165),

\begin{abstract}
Apesar de serem encontradas evidências de aprendizagem, como conversas perceptivas (de identificação e nomeação) e conectivas (com experiências passadas), conforme as categorias de Allen (2002), não é possível assumir que esses visitantes estavam em atividade de aprendizagem do conceito, no sentido aqui trabalhado, pois para tal, seriam necessárias não só a transformação do sujeito, sua autotransformação, mas a re-produção, por ele, do discurso exposto no Museu.
\end{abstract}

Com relação ao trabalho pedagógico em museus, sua pesquisa conclui ainda que, dentre as preocupações da equipe expográfica e pedagógica do museu, deve estar o desenvolvimento de um discurso expositivo que desenvolvesse a intencionalidade da aprendizagem no visitante, na medida em que é intencionalmente que o indivíduo se implica em uma atividade de aprendizagem (BIZERRA, 2009).

Nossa opção teórica aproxima-se da abordagem da Teoria da Atividade no sentido de considerar a organização psíquica integral do indivíduo concreto, mesmo que não considerada na sua complexidade constitutiva. Assim, como Bizerra (2009), interessa-nos, igualmente, o movimento do sistema psíquico no processo de aprender; as tensões e contradições que o conformam.

A Teoria da Subjetividade parte, igualmente, da perspectiva histórico-cultural que entende a constituição sistêmica, histórica e cultural da psique humana. Diferencia-se, no entanto, ao atribuir essa organização, não à relação direta com a atividade, consciente e intencional, do indivíduo em contexto, mas à produção subjetiva frente à realidade que se apresenta. Para González Rey (2003, 2010a, 2010b), a centralidade do conceito da "ação" como princípio explicativo da organização psíquica humana acaba por suprimir, de forma análoga a 
perspectiva sociocultural, o caráter histórico-dialético dos processos psíquicos. Aspectos psíquicos como as "emoções" ou a "intenção" são reduzidos ao "motivo da ação" e à "significação da ação", respectivamente.

À nossa perspectiva teórica, subjaz a crítica à interpretação do conceito de interiorização de Vigotski por essa estabelecer uma dicotomia rígida e uma relação direta e linear entre exterior e interior, entre o individual e o social. Igualmente sensível a essa crítica, Bizerra resolve essa questão a partir da Teoria da Prática Social, conforme proposto por Lave e Wenger, que atribui à dimensão relacional da prática a interdependência entre agente, atividade, significado, cognição, aprendizagem e conhecimento (BIZERRA, 2009). Assim, Bizerra tem como concepção de internalização não o processo de transmissão do social para o individual, mas "um processo articulatório entre dois planos mutuamente constituintes" (pg.176); assumindo que a abordagem de Lave e Wenger soma-se à de Vigostki, ao invés de lhe ser excludente.

Em nossa concepção, no entanto, a solução de Lave e Wenger (apud BIZERRA, 2009) à questão da interiorização, ainda que proponha a dimensão relacional da prática social como forma de resolver o problema da dicotomia e da linearidade externo e interno, não consegue resolvê-la na medida em que atribui à dimensão relacional, externa ao sujeito, a organização e o funcionamento psíquico. Termina, assim, por não considerar o sujeito enquanto produtor de emoções que o organizam em sua constituição histórica e o singularizam no processo de aprendizagem. Essa consiste a proposta nevrálgica da Teoria da Subjetividade, a perspectiva

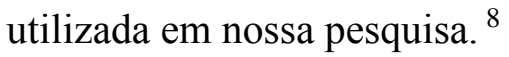

\subsubsection{O Modelo Contextual}

O Modelo Contextual, desenvolvido por Falk e Dierking (1992), intenta elencar fatores que moldam, de forma específica, a aprendizagem em museus. O modelo parte da compreensão da aprendizagem como um processo altamente situado, resultante de um diálogo contínuo e aberto entre o indivíduo e seu ambiente físico e social.

De forma a entender as características específicas da aprendizagem em museus, Falk (1999) aponta a liberdade de escolha como um grande diferencial. Em sua conhecida análise,

\footnotetext{
${ }^{8}$ No próximo capítulo do trabalho, ao introduzirmos a Teoria da Subjetividade e suas categorias centrais, este tópico será novamente abordado em maiores detalhes.
} 
propõe museus como instituições de Free-Choice Learning (aprendizagem por livre escolha), onde o interesse e a intenção de aprendizagem tem origem no indivíduo, caracterizando-se, dentro da linha construtivista, pela motivação intrínseca.

Falk e Storksdieck (2005) refinaram o modelo, identificando 11 fatores que afetam a aprendizagem em três domínios contextuais. Segundo os autores, se algum desses fatores é negligenciado, a construção da aprendizagem se torna mais difícil. Os domínios e seus fatores são:

(1) O Contexto Pessoal: representa a soma total da história pessoal e genética que o indivíduo traz para uma situação de aprendizagem. A partir da perspectiva do contexto pessoal, a aprendizagem seria influenciada por:
a. Motivações e expectativas
b. Conhecimento prévio e experiências de vida
c. Interesses prévios e crenças
d. Possibilidade de escolha e controle

(2) O Contexto Social: premissa de que, como instituições situadas em um contexto sociocultural, a aprendizagem nesses espaços seria influenciada por:
a. Mediações socioculturais em grupos sociais
b. Mediações orientadas por outros

(3) O Contexto Físico: premissa de que a aprendizagem acontece em um contexto físico e, portanto, está sempre em diálogo com ele. Nessa perspectiva, a aprendizagem é influenciada por componentes do ambiente tais como:
a. Organizadores avançados;
b. Orientadores para o espaço físico
c. Arquitetura e ambiente geral
d. Design da exposição e etiquetas informacionais
e. Eventos de reforço e experiências fora do museu

As pesquisas orientadas pelo Modelo Contextual fazem uso de instrumentos metodológicos, tais como registro de tempo, mapas mentais pessoais antes e após a visita (os PMM - Personal Meaning Maps), perguntas de múltipla escolha e perguntas abertas antes e 
após a visita. Na pesquisa sobre o impacto do conhecimento prévio e do interesse na aprendizagem de um grupo de visitantes ao Museu Aquarium, Falk e Adelman (2003) tentam categorizar aprendizagens sobre preservação ambiental, a partir de níveis mínimo, moderado e extenso, e concluem que todos os fatores elencados se inter-relacionam.

O estudo leva os autores a criticarem as pesquisas, tanto das abordagens construtivistas e socioculturais, quanto do próprio Modelo Contextual por eles desenvolvido, na medida em que falham em captar, mais eficientemente, a grande variabilidade de conhecimentos prévios presentes em indivíduos singulares e que, por isso, experienciam a visita de forma singular. Falk (2004) reconhece o grande avanço da compreensão da aprendizagem em museus da última década, a partir das pesquisas de abordagem sociocultural, mas denuncia ainda a incapacidade das pesquisas em compreenderem, de forma mais sistêmica e em profundidade, todos os diversos fatores elencados de forma conjunta.

Para Falk (2003, 2004), as pesquisas tendem, ainda, a concentrar atenções às interações sociais e comportamentos ocorridos durante a visita, perdendo-se de vista a compreensão mais profunda de quem são os indivíduos que participam da ação educativa e de como eles são impactados por essa ação para além dela, em outros contextos de suas vidas.

Segundo o autor, há que se considerar, por exemplo, que as pessoas se constituem de múltiplas histórias; que produzem diferentes sentidos de uma mesma memória em diferentes momentos; que a motivação e a identidade do aprendiz potencializam a aprendizagem, e que o que se aprende hoje depende, enormemente, do que se aprendeu ontem e de como isso será interpretado em ocasiões futuras. Nesse sentido, o autor fala da necessidade de "escopo e escala" para as pesquisas, remetendo à necessidade de recortes mais verticais, que dêem conta da variedade de experiências que ocorrem nos museus e, também, mais horizontais, que compreendam essas experiências em conexões com a vida integral dos sujeitos (FALK, 2003). As ideias do autor são, no Brasil, referendadas por Bizerra e Marandino (2009).

Concordamos com essa crítica de John Falk e acreditamos que processos de aprendizagem não se constituem a partir da articulação direta de múltiplos fatores, entre eles o emocional, o cognitivo, o social e o ambiente físico, mas como momentos de produção subjetiva do sistema subjetivo do aprendiz. Neste sistema, integram-se configurações subjetivas organizadas na trajetória de vida da pessoa e sentidos subjetivos produzidos no momento atual. A constituição subjetiva do aprendiz é, em nossa opção teórica, elemento essencial para a 
compreensão dos processos de aprendizagem, na medida em que ela define o sentido que esses processos têm para esse sujeito na condição singular em que este se encontra inserido no seu momento, ao mesmo tempo, histórico e concreto. Conforme González Rey (2008, p. 34),

As emoções que o sujeito vai desenvolver no processo de aprendizagem estão associadas não apenas com o que ele vivencia como resultado das experiências implicadas no aprender, mas emoções que têm sua origem em sentidos subjetivos muito diferentes que trazem ao momento atual do aprender momentos de subjetivação produzidos em outros espaços e momentos da vida. Daí, a importância de considerar o sujeito que aprende na complexidade de sua organização subjetiva $[\ldots]^{9}$

Pensamos que a compreensão da constituição subjetiva do aprendiz, ao mesmo tempo histórica e concreta, nos permite um arcabouço teórico para uma compreensão mais profunda da aprendizagem em museus que parte da condição singular do aprendiz e da forma este subjetiva sua experiência no contexto da visita.

\subsection{As Pesquisas sobre identidade de aprendizagem}

Diversas pesquisas, em especial na área de públicos de museus, já apontaram para a capacidade da experiência museal em influenciar a identidade e o sentido de "self" do visitante (FALK, 2004, 2006; KELLY, 2002, 2007). Em concordância com essas pesquisas, e a partir delas, nos parece importante citar o trabalho de Lynda Kelly, diretora do Australian Museum Audience Research Center, na área de identidade de aprendizagem em museus.

Em seu grupo, Kelly (2002, p.12, tradução nossa) define a aprendizagem como "um processo dinâmico, dependente ao indivíduo e seu meio dentro de um contexto social, que foca alguma mudança”. Para a autora (KELLY, 2002, p.12, tradução nossa),

A aprendizagem em museus é sobre "mudar-se como pessoa: o que consiste não só no quanto uma visita inspira e estimula a vontade das pessoas em aprender mais, mas também no quanto ela permite que essas pessoas transformem suas formas de se ver, a si próprias e ao seu mundo, como indivíduos e como parte de uma comunidade.

Kelly (2007) prossegue essa análise e ocupa-se com uma pesquisa que parte das seguintes questões: o que pensam os visitantes sobre o que é aprendizagem? Como visitantes veem a si mesmos como aprendentes em um contexto de uma visita ao museu? Se estão cientes, ou não, de como gostam de aprender, de como podem aprender de diferentes formas, das formas

\footnotetext{
${ }^{9}$ A categoria de "sentido subjetivo" citada pelo autor será aprofundada no capítulo II, deste trabalho, que apresenta o arcabouço teórico central da pesquisa.
} 
pelas quais não gostam de aprender e de como poderiam adaptar suas preferências de aprendizagem.

A partir do entendimento de que a identidade ${ }^{10}$ é parte integral da experiência de aprendizagem, Kelly (2007) sugere o chamado "Modelo 6P”. Neste modelo, a identidade de aprendizagem, isto é a forma pela qual o indivíduo percebe a si mesmo enquanto aprendente, é compreendida como o elemento central que conecta outros cinco elementos da experiência de aprendizagem no museu: objetivo, processo, pessoas, lugar e produto. Em sua pesquisa, por meio de entrevistas e questionários, a autora conclui que a experiência da visita a uma exposição pode atingir a identidade de três formas:

- Influenciando a identidade de aprendizagem de visitantes na medida em que eles aprendem em suas experiências museais e se desenvolvem mais confiantes em suas aprendizagens;

- Integrando-se à identidade do visitante;

- Entrando em conflito com a identidade do aprendente e reforçando na mente do visitante as formas em que ele não aprende.

Para a pesquisa sobre a aprendizagem em museus, o tema de identidade de aprendizagem apresenta-se bastante relevante, pois coloca em discussão a qualidade da influência da experiência educativa no museu na identidade de aprendizagem do visitante. Ou, conforme Kelly (2007) coloca, na sua capacidade de transformar as formas do visitante ver a si próprio e desenvolver-se mais confiante para novas aprendizagens.

Na presente pesquisa, subscrevemos a importância da compreensão das formas com as quais a experiência museal, não-formal, impacta a identidade de aprendizagem. Sob a perspectiva teórica da subjetividade, compreendemos, no entanto, que a identidade de aprendizagem se constitui nas produções subjetivas da pessoa frente a uma situação concreta de aprender. É na forma como o indivíduo subjetiva a experiência vivenciada que aparece a sua necessidade de se reconhecer a si mesmo, de delimitar seu espaço, de encontrar congruência consigo mesmo frente à determinada situação.

\footnotetext{
${ }^{10}$ A partir do enfoque da Teoria da Aprendizagem Social, Kelly (2007) define identidade como sendo a expressão de como uma pessoa percebe a si própria em relação ao seu mundo e a seu papel nele. Para a pesquisadora, a identidade é uma categoria fluida, moldada pelo contexto social e que se modifica a partir de fatores diversos tais como a idade, o gênero, contextos cultural e socioeconômico e a experiência de vida. (KELLY, 2007)
} 
Conforme González Rey (2005) coloca, a identidade deixa de ser um sistema de estruturas estáveis e ordenadas, independente dos espaços e tempos em que se manifesta a atividade do sujeito, ou um sistema resultante da interação direta entre aspectos do indivíduo em interação com aspectos do contexto social no qual está inserido, para se constituir como expressões de sentido subjetivo que podem aparecer de formas diversas e em contextos diferentes, dependendo do jogo das produções simbólico-emocionais comprometidas na situação.

Sob essa perspectiva, assumimos ainda que experiências de aprendizagem podem impactar de diferentes maneiras nossa identidade de aprendizagem, na medida em que impactam de diferentes formas nosso sistema subjetivo.

\subsection{Pesquisas sobre a Relação Museu-Escola}

Museus e escolas são espaços que se diferenciam quanto ao seu objeto, sua relação com o público, suas propostas educacionais, suas formas de apresentar conteúdo, quanto ao tempo e periodicidade de suas ações, entre outros aspectos.

Koptke (2002) aponta que a relação museu-educação formal se constituiu historicamente, de forma complexa; diferentes tipos dessa relação coexistem (coabitação, colaboração, complementaridade), a depender das características da instituição e dos interesses políticos em jogo. Defende que esta deva ser entendida como uma parceria construída de forma contextualizada, pelos atores sociais, dentro da dinâmica social sob o qual se desenvolve.

A complexidade dessa relação se reflete nos estudos da área. Enquanto uma série de estudos procura reforçar a complementariedade na relação museu-escola (COSTA et al., 2007; GASPAR, 1993; KÖPTCKE, 2002), outros apresentam uma série de desafios desta parceria. Entre esses desafios, aponta-se a crítica à excessiva "escolarização" das exposições museais e à avaliação da aprendizagem museal por meio da ótica escolar, tradicionalmente privilegiadora de fatores cognitivos (FALK; DIERCKING, 1992); a denúncia da "pouca" aprendizagem devido, entre outros fatores, à excessiva ludicidade das exposições, e, por fim, a crítica à falta de preparo dos professores e de clareza dos papéis do professor e do monitor durante as visitas (SÁNCHEZ MORA, 2007). 
No que se refere à tendência da avaliação da aprendizagem em museus por meio da ótica escolar, os estudos de Falk e Dierking (1992) sugerem que há evidências indiretas de aprendizagem em museus, porém poucos demonstraram efetivamente o aprendizado de fatos e conceitos durante as visitas. Segundo os autores, uma manifestação desta confusão é a equivocada noção de que o aprendizado é primariamente a aquisição de novas idéias, fatos ou informações ao invés de ser considerado como uma consolidação lenta e gradual de idéias e informações pré-existentes (FALK; ADELMAN, 2003; FALK; DIERCKING, 1992). Para esses autores, fatores afetivos e psicomotores influenciam a qualidade da aprendizagem em museus que, no entanto, é predominantemente avaliada apenas pelos ganhos cognitivos.

Com efeito, de maneira análoga a esse entendimento, outros autores reconhecem também a importância dos fatores afetivos na motivação, na concentração e na construção do conhecimento a partir da exposição. (CSIKSZENTMIHALYI; HERMANSON, 1995; PORTO, 2008) Concluem, de forma geral, que a experiência vivenciada em um museu não deve ser considerada por sua eficácia em transmitir grandes quantidades de informação, mas sim pelo seu potencial em gerar interesse e entusiasmo.

Partindo do enfoque do estudo sobre comunicação expositiva, Marandino (2003) sugere que o papel da mediação humana no museu deve ser dimensionado. "Museus não são escolas e mediadores não são professores". A autora, mesmo reconhecendo o grande valor da mediação humana para a aprendizagem em museus, sugere que a comunicação expositiva deve atentar para não depender da mediação humana para sua compreensão. Para a autora, "encontrar a linguagem educativa e comunicativa que respeite as especificidades dos museus [...] é um dos grandes desafios" (MARANDINO, 2003, p. 119).

Costa et al (2007) defendem que, por possuírem maior liberdade na seleção e organização de conteúdos e metodologias de ensino, museus ampliam as possibilidades para o desenvolvimento de um trabalho educativo interdisciplinar, historicizado e contextualizado. Justificam, assim, a parceria museu-escola na tentativa de subverter, como um dos meios da educação não-formal, a lógica homogeneizante, reprodutivista e reificadora do conhecimento, dominante no sistema escolar, que está sujeito ao Sistema Nacional de Ensino.

Almeida (1997) aponta ainda diferenças entre a educação museal e a educação escolar na medida em que museus, como instituições ligadas à educação patrimonial, devem buscar, como forma essencial para o desenvolvimento da condição de cidadão, a permanente leitura 
crítica e criativa dos visitantes sobre as temáticas museais. Nessa direção, segundo a autora, a educação de museus deve ir além da escola.

Em suma, a relação museu escola não ocorre sem desafios e as inter-relações entre a aprendizagem museal e a aprendizagem escolar, apesar de amplamente reconhecidas, não são ainda compreendidas em sua devida profundidade (ANDERSON; LUCAS; GINNS, 2003). Em nosso entendimento, a compreensão das inter-relações entre a aprendizagem nos contextos formal e não-formal, envolve a compreensão de como as aprendizagens são retomadas em diferentes contextos e momentos. Isso nos conduz a indagações tais como: o que nos leva a retomar um aprendizado? Como diferentes tipos de aprendizagem, entre eles a aprendizagem memorística, reprodutiva, compreensiva e/ou criativa favorecem a utilização do aprendizado em diferentes contextos?

Conforme abordado na introdução, partimos de uma hipótese interpretativa inicial de que a aprendizagem criativa, por se constituir a partir de uma produção subjetiva qualitativamente diferenciada, caracterizada pela forte implicação do aprendiz com seu processo de aprender e com o aprendizado em si, tem o potencial para favorecer a retomada do aprendizado criativo em diferentes contextos para além do contexto original de aprendizagem. Acreditamos ser essa uma via potencial para a compreensão das inter-relações entre as aprendizagens em diferentes contextos e, no caso aqui colocado, entre contextos formais e nãoformais.

No próximo capítulo, apresentaremos a Teoria da Subjetividade e as principais categorias de forma a subsidiar o arcabouço teórico de nossa proposta de pesquisa. 


\section{CAPÍTULO II - ARCABOUÇO TEÓRICO CENTRAL}

\subsection{A Teoria da Subjetividade de Fernando González Rey}

A busca pela compreensão dos processos constitutivos da aprendizagem criativa no contexto não-formal requer a eleição de uma teoria explicativa da psique humana que logre a compreensão da constituição, simultaneamente, da singularidade e da sociogênese dos indivíduos. Desenvolvida por González Rey, com base nos estudos de Vigotski e em autores como L.I. Bozhovich (1908-1976), S.L. Rubinstein (1889-1960) e K. A. Abuljanova, a subjetividade, sob o marco histórico-cultural, é entendida como um sistema complexo, aberto e auto-organizado de produções simbólico-emocionais, que acontece simultaneamente em nível individual, na trajetória de vida singular do indivíduo, e em nível social nos espaços sociais onde os indivíduos atuam. Essas duas instâncias, ainda que se desenvolvam em tempos e níveis diferenciados, integram-se reciprocamente na trama complexa e dinâmica de configurações e sentidos subjetivos na psique do indivíduo e na psique social, entendidas ambas enquanto sistemas subjetivos. (GONZÁLEZ REY, 1997, 2001, 2005a, 2005c, 2006)

Há duas acepções para o termo subjetividade na Teoria da Subjetividade.

Em primeiro, a de um nível macroteórico composto por um conjunto categorias teóricas de valor heurístico para a compreensão da psique enquanto sistema complexo e dinâmico. Categorias tais como subjetividade individual, subjetividade social, sujeito, sentido subjetivo, configurações subjetivas, personalidade, entre outras.

Conforme elaboradas por González Rey, algumas dessas categorias se constituem umas às outras reciprocamente, operando de forma recursiva. Como veremos em breve, o sentido subjetivo se constitui em meio a configurações subjetivas, ao mesmo tempo em que configurações subjetivas são constituídas por sentidos subjetivos. Da mesma forma, a subjetividade individual se constitui a partir da subjetividade social, ao mesmo tempo em que esta se constitui daquela. Trata-se, assim, de categorias que permitem a compreensão das interrelações dinâmicas que associam entre si o antagônico, o dialético e o recursivo, próprios da complexidade inerente ao sistema psíquico. Assemelham-se assim, à ideia dos macroconceitos do pensamento complexo, conforme proposto por Morin. Segundo Moraes (2004),

Ao pensarmos em termos de macroconceitos, estaremos pensando na dinâmica relacional que envolve esses conceitos, em algo que não é fechado, estático e monolítico, mas aberto processual, e sempre em movimento. [...] Não são 
conceitos enclausurados, mas inter- relacionados, abertos, produtos de constelações dinâmicas (p. 55).

Integra-se ainda a essa acepção, a capacidade da Teoria da Subjetividade de reconhecer construtos teóricos tais como a cognição, a identidade, as representações, a motivação, entre outros, entendendo-os como processos cujas gênese, funcionamento e organização conformamse em processos de subjetivação. (GONZÁLEZ REY, 2005a)

A segunda acepção do termo subjetividade relaciona-se a uma das categorias teóricas da Teoria da Subjetividade em si. Refere-se ao sistema complexo, aberto e auto-organizado de produções subjetivas que se organiza tanto em nível individual, na trajetória de vida singular do indivíduo, quanto em nível social, nos espaços sociais onde os indivíduos atuam. Essas duas instâncias, ainda que se desenvolvam em tempos e níveis diferenciados, se integram reciprocamente na trama complexa e dinâmica de configurações e sentidos subjetivos na psique do indivíduo e na psique social, entendidas ambas enquanto sistemas subjetivos.

No marco histórico-cultural, a subjetividade deixa de ser compreendida como uma dimensão intrapsíquica na medida em que os indivíduos são sociais, enquanto constituídos pelo social em sua existência concreta. Ao mesmo tempo, a consideração da indissociabilidade entre o simbólico e o emocional é, na visão de González Rey, precisamente o que confere ao indivíduo a singularidade de suas experiências de vida e a sua condição de sujeito criador. (GONZÁLEZ REY, 2011).

Reconhece-se, por base, que nossa relação com o mundo simbólico, se integra a sistemas subjetivos individuais, permeados por implicações emocionais que se conformam na trajetória de vida singular dos indivíduos e na subjetividade social dos espaços sociais onde estes indivíduos atuam. Coexistem, assim, no sistema subjetivo da pessoa, momentos de expressão de nível individual e momentos de expressão de nível social que interagem em tensão própria em sua constituição subjetiva, sem que um se dilua no outro.

Nesta perspectiva teórica, assume-se, a sociogênese do indivíduo, própria do marco histórico-cultural, sem que esta signifique, porém, a expressão direta e linear do social sobre o indivíduo. Em outras palavras, assume-se que a forma como subjetivamos o mundo (simbólico e relacional) não é uma expressão linear, direta, causal e, portanto, determinada pela nossa relação objetiva com ele. Ao contrário, esta relação é mediada pela psique humana enquanto 
permanente produtora de sentidos subjetivos, tomados como a união indissociável entre o simbólico e o emocional. Para González Rey (2005a, p.202) a subjetividade:

[...] não se trata de um sistema associado somente às experiências atuais de um sujeito ou de uma instância social, mas um sistema associado às formas em que uma experiência atual adquire sentido e significação dentro da constituição subjetiva da história desse sujeito ou dessa instância social.

González Rey nos brinda, assim, com uma matriz teórico-explicativa preocupada com o resgate de um sujeito não determinado pelas instâncias sociais. Opõe-se a diversas correntes teóricas e epistemológicas modernas e pós-modernas que no decorrer do século $\mathrm{XX}$, se constituíram hegemônicas e que se ocuparam do simbólico como matriz explicativa do humano. Nesta contramão, o autor se insere a um conjunto de autores pós-psicanalistas, entre eles Castoriadis e Guattari, ocupados com o resgate da capacidade criadora do indivíduo que é ao, mesmo tempo, constituído e constituinte de cultura.

Como um novo espaço qualitativamente diferenciado "das experiências atuais" ou de uma "instância social", a subjetividade permite uma nova inteligibilidade sobre o sistema da psique humana, quebrando tradicionais dicotomias do pensamento teórico e epistemológico moderno: o social e o individual, o interno e o externo, o simbólico e o emocional.

Sua compreensão exige o esclarecimento das categorias de subjetividade social e individual, conforme propostas por González Rey. Vejamos, com maior profundidade, o entendimento sobre essas e outras de suas principais categorias.

A subjetividade social remete aos processos históricos de organização de sentidos subjetivos produzidos nos espaços sociais onde indivíduos atuam. A subjetividade social, por exemplo, da escola pode se expressar nas crenças, nos valores, nas representações e nas práticas que caracterizam a escola como espaço social, revelando complexas significações simbólicoemocionais compartilhadas pelo grupo social desse contexto. Tais crenças, valores e práticas, por sua vez, se expressam, nas subjetividades individuais dos alunos de várias formas como, por exemplo, em sentidos subjetivos relacionados à: autoridade do professor, avaliação escolar, rigidez de horários, hora da saída, entre outros.

A subjetividade social mantém uma relação constitutiva das subjetividades individuais das pessoas que participam de seus espaços, ao mesmo tempo em que se constitui dessas mesmas subjetividades individuais. Essa relação processual e recursiva se estabelece a partir de 
três entendimentos. Em primeiro, o entendimento de que, em sua atuação em espaços sociais, o indivíduo produz elementos de sentido e significado que são, ao mesmo tempo, compartilhados socialmente e expressões da subjetividade individual. Em segundo, o entendimento de que, por se constituírem historicamente, esses espaços da subjetividade social integram às subjetividades individuais elementos de sentido e significado produzidos em outros momentos históricos e em outros espaços sociais, que antecedem a organização psíquica dos indivíduos. (GONZÁLEZ REY, 1999a, 2004, 2005a)

Por fim, em terceiro, o entendimento de que o indivíduo, em sua condição subjetiva de sujeito, caracterizada por estados de ruptura e subversão às configurações da subjetividade social, pode influenciar e mudar essas configurações. Conforme aponta González Rey (2007, p.235), "o sujeito em sua processualidade reflexiva intervém como momento constituinte de si mesmo e dos espaços sociais em que atua, a partir dos quais pode afetar outros espaços sociais." Dessa forma, a atuação de sujeito em um espaço escolar específico, seja ele, aluno, diretor, professor, pode se contrapor às configurações da subjetividade social e alterar não só a sua organização subjetiva individual, como a própria subjetividade social presente nesse contexto escolar específico.

Na categoria da subjetividade individual, reconhece-se, por base, que nossa relação com o mundo simbólico, se constitui por meio de um sistema subjetivo individual, permeado por implicações emocionais que se conformam na trajetória de vida singular do indivíduo e na subjetividade social dos espaços sociais onde este indivíduo atua. Coexistem, assim, no sistema subjetivo da pessoa, momentos de expressão de nível individual e de nível social que se tensionam entre si, na dinâmica constitutiva da subjetividade individual.

A subjetividade individual não se refere, assim, a uma dimensão intrapsíquica idealista. Ela é percebida como uma nova dimensão ontológica, que se constitui na experiência histórica e concreta dos indivíduos; uma dimensão qualitativamente diferenciada tanto da "experiência atual” do indivíduo, quanto da internalização direta do social. Para González Rey (2005, p.202) trata-se de um sistema: [...] associado às formas em que uma experiência atual adquire sentido e significação dentro da constituição subjetiva da história desse sujeito [...]. O autor propõe, assim, um arcabouço teórico que permite a compreensão do individual e do social, do interno e do externo, do cognitivo e do emocional, enquanto instâncias sistêmicas que se constituem reciprocamente, superando, assim, tradicionais dicotomias das ciências antropossociais 
modernas e recuperando a capacidade geradora do sujeito. (GONZÁLEZ REY, 1997, 2001, 2005a, 2005c, 2006)

Segundo o autor, é precisamente a inclusão do emocional como dimensão constitutiva da psique e de seus processos o que confere ao indivíduo a singularidade de suas experiências de vida e a sua condição de sujeito criador, constituído e constituinte de cultura (GONZÁLEZ REY, 2011).

Por sua vez, a categoria de configurações subjetivas corresponde a uma conformação de sentidos subjetivos qualitativamente diferenciada, que adquirem um valor específico na organização subjetiva da pessoa em cada momento de sua ação. Para um aluno com dificuldades de aprendizagem na escola, pode-se supor uma configuração subjetiva do aprender na escola que se constitua como um conjunto de sentidos subjetivos e outras configurações subjetivas associados, por exemplo, ao sistema de avaliação escolar, à relação com a família, à relação com o professor e com o grupo de colegas, à forma como subjetiva aspectos em relação a seu gênero, cor, condição social, entre outros. Esta configuração subjetiva do aprender na escola integra, em forma de sentidos subjetivos, outras esferas e aspectos da vida do aluno muito diferenciados do contexto e das atividades do aprender em si (GONZÁLEZ REY, 2012, 2011).

Ao mesmo tempo, por serem sempre produções atuais, realizadas no contexto concreto da ação e, portanto, em permanente articulação com novos sentidos subjetivos produzidos frente à experiência, configurações subjetivas são dinâmicas, flexíveis e podem se alterar no curso das ações e experiências do indivíduo. Nessa elaboração, as configurações não são determinantes da experiência do sujeito, segundo afirma González Rey (2005c, p.35),

[...] a produção atual de sentidos subjetivos, que caracteriza os diferentes instantes da vida do sujeito dentro de seus diversos campos de atividade, nunca está determinada, a priori, desde a natureza da configuração subjetiva. Toda produção de sentidos subjetivos é o resultado da tensão entre os sentidos que aparecem no percurso da ação do sujeito e os sentidos que antecedem esse momento, a partir das configurações subjetivas implicadas em cada situação concreta dessa ação.

A categoria de configurações subjetivas permite uma revisão da compreensão da personalidade que passa a ser entendida não mais como traços inatos da pessoa ou perfis padronizados de comportamento, mas como um sistema de configurações subjetivas que, embora "mais estável" nas experiências de vida da pessoa, adquire plasticidade como sistema aberto, atualizável a partir de novas produções de sentido no curso da vida do indivíduo. A personalidade deixa de ser vista, assim, como uma categoria intrapsíquica, interna à pessoa, 
para ser compreendida como um momento de organização e produção subjetiva que emerge no curso de sua ação.

Em seus trabalhos mais recentes, para enfatizar o caráter atual da configuração subjetiva, que se conforma no curso da ação da pessoa, e que integra, para além de sentidos subjetivos constituintes da personalidade, elementos subjetivos como o motivo que se expressa no contexto da ação e a subjetividade social do contexto onde a ação ocorre, González Rey avança seu pensamento com a proposição da categoria da configuração subjetiva da ação (GONZÁLEZ REY, 2011, 2012a, 2012b, ARTIGO E)

Nesta elaboração, a personalidade se expressa como elemento de sentido subjetivo na trama múltipla e diversa de sentidos subjetivos que são produzidos no curso da ação e que emergem como configuração subjetiva. Segundo o autor (2012, p. XX),

A personalidade aparece nas configurações subjetivas da ação não através de sentidos subjetivos que "vêm prontos" da personalidade para ação.

Ainda em outro momento, González Rey coloca (no prelo, tradução nossa)

A personalidade é o sistema de configurações subjetivas que está presente em cada momento da vida da pessoa por meio da metamorfose de suas expressões nas diferentes configurações subjetivas da ação em cada domínio da vida da pessoa.

Com esta compreensão, assumimos a configuração subjetiva da ação do aprender como a trama complexa e dinâmica de produções simbólico-emocionais que se articulam no momento do aprender e que se constitui da expressão de elementos de sentidos subjetivos da subjetividade social onde a aprendizagem se realiza, de configurações subjetivas da personalidade, e de novos sentidos subjetivos produzidos no curso da ação. Nesta pesquisa, exploramos, em especial, esta categoria teórica em nossa busca por compreender as formas de organização e produção subjetiva em contextos não-formais de aprendizagem, e suas relações com a possibilidade de ocorrência, ou não, da criatividade na aprendizagem.

Como unidades constitutivas das configurações subjetivas, encontram-se os sentidos subjetivos. Categoria em que, González Rey, amplia o sentido em Vigotski, originalmente limitado à organização psíquica perante a palavra, definindo-o como a unidade entre o emocional e o simbólico, produzida por indivíduos em um contexto/espaço cultural.

[...o sentido subjetivo] representa um sistema simbólico-emocional em constante desenvolvimento, no qual cada um desses aspectos se evoca de forma recíproca, sem que um seja a causa do outro, provocando constantes e imprevisíveis 
desdobramentos que levam a novas configurações de sentido subjetivo. [...] permitem-nos representar o envolvimento afetivo do sujeito em uma atividade, não apenas pelo seu vínculo concreto nela, mas como produção de sentidos que implica em uma configuração única, sentidos subjetivos, emoções e processos simbólicos. (GONZÁLEZ REY, 2008, pg. 34)

O sentido subjetivo consiste, em si, um sistema complexo e dinâmico em que elementos simbólicos e emocionais emergem, se influenciam e se organizam entre si. Ainda conforme o autor, o sentido subjetivo "se manifesta pela relação de uma emoção com outras em espaços simbolicamente organizados, dentro dos quais as emoções transitam” (GONZÁLEZ REY, 2005a, pg.243).

Ao consistirem, sempre, uma produção atual da pessoa, os sentidos subjetivos não se estabelecem a partir de uma relação linear e direta com os elementos que participam de sua gênese; não são resultantes diretos de influências externas (GONZÁLEZ REY, 2005a). Sentidos subjetivos integram, na produção atual do indivíduo, aspectos de sua história individual, procedentes de momentos e espaços diversos. Em outras palavras, a cada momento atual de produção subjetiva, sentidos subjetivos emergem da inter-relação entre as configurações subjetivas da personalidade, mais estáveis enquanto produções subjetivas, e novos sentidos no curso da ação do indivíduo. González Rey (2001, p.19, tradução nossa) exemplifica,

[...] assim, a produção de sentidos subjetivos de uma criança na escola integra elementos de sentido provenientes de espaços muito diversos de sua experiência, como por exemplo, relacionados a sua raça, gênero, condição social, físico, etc, os quais se integram no sentido que a escola e a aprendizagem têm para ela, aparecendo em suas diferentes atividades escolares sem a menor evidência sobre sua presença, nem para a criança, nem para que a rodeia.

Esses sentidos subjetivos produzidos na escola não se mantêm fixos; ao contrário, modificam-se com as experiências que a criança vivencia, tanto na própria escola quanto fora dela. Experiências que constituem momentos sensiveis de produção subjetiva que acabam por influenciar a produção subjetiva na escola (GONZÁLEZ REY, 2001). No que concerne aos contextos da educação não-formal, a busca por essa possibilidade de desenvolvimento da subjetividade, processo que veremos a seguir, poderia vir a ser um dos grandes desafios e objetivos da relação museu-escola, ou mais amplamente, da educação formal e não-formal.

O sentido subjetivo está para além da consciência do sujeito, o que não quer dizer que as atividades conscientes não participem do processo subjetivo. A complexa forma dentro da qual as emoções emergem e interagem com elementos simbólicos na formação do sentido 
subjetivo não se subordina à capacidade consciente ou à racionalidade. González Rey (2005a, p.252) coloca

O sentido é subversivo, escapa do controle, é impossível de predizer, não está subordinado a uma lógica racional externa. $\mathrm{O}$ sentido se impõe à racionalidade do sujeito, o que não implica a sua associação só ao inconsciente [...] pois um mesmo sentido transita por momentos conscientes e inconscientes, até mesmo de forma contraditória.

Conforme apontado, é precisamente por meio da categoria, em que o emocional e o simbólico integram-se de forma processual e auto-organizada, que González Rey abre possibilidades para a compreensão da singularidade enquanto condição constitutiva do homem em suas experiências de vida, assim como para a emergência da condição de sujeito enquanto gerador de espaços de subjetivação próprios e diferenciados em relação à subjetividade social dominante.

A categoria sujeito refere-se, para González Rey, como um momento de produção subjetiva em que o indivíduo tem consciência da processualidade de sua própria produção subjetiva e em que, em vista dessa consciência, mobiliza recursos que indiretamente influenciam essa produção. Dessa forma, para o autor, "reconhecer um sujeito ativo é reconhecer sua capacidade de construção consciente como momento de seus processos atuais de subjetivação, o que não significa que estes se ajustem a um exercício da razão [...]" (GONZÁLEZ REY, 2005a, p. 26)

Para González Rey, a consciência na subjetividade, não é sinônimo de razão, é sinônimo de "representação, intencionalidade e reflexividade enquanto processos comprometidos com a ação do sujeito" (GONZÁLEZ REY, 2005a, p. 226). Essa capacidade de influenciar processos subjetivos inconscientes atribui ao sujeito sua capacidade de engendrar caminhos alternativos de produção subjetiva em momentos em que necessita. A condição de sujeito associa-se, assim, à capacidade de gerar novas opções de processos subjetivos, de gerar rupturas com a subjetividade estabelecida, nas dimensões individual e social e, por fim, de gerar novas possibilidades de ação criativa. É precisamente essa capacidade geradora do sujeito um dos importantes elementos dos processos de mudança e desenvolvimento da subjetividade, tanto individual quanto social. Segundo o autor (GONZÁLEZ REY, 2007a, p. 174),

Uma característica essencial da subjetividade é sua capacidade para subverter a ordem institucional que caracteriza a organização hegemônica de qualquer ordem social. Tem sido precisamente essa tensão e contradição permanente um dos elementos principais da constante mudança da sociedade. Negar a subjetividade 
é equivalente a desconsiderar a força da produção humana mais genuína, e nos submeter ao domínio do instrumental.

Assumir a subjetividade como uma nova representação ontológica da psique humana, compreendendo esta como sistema complexo engendrado pela inter-relação dinâmica e processual das categorias apresentadas, acarreta um novo olhar sobre processos de impacto e desenvolvimento da subjetividade. Processos relevantes para a compreensão do potencial valor das experiências de aprendizagem sob essa perspectiva teórica. Serão esses processos os nossos tópicos a seguir.

\subsection{Movimentos da Subjetividade}

Pesquisas na área da aprendizagem criativa, conforme nossa perspectiva teórica, têm evidenciado a influência deste tipo de aprendizagem em movimentos subjetivos que, recursivamente, alimentam novas produções subjetivas que conformam a motivação a incursão em novos processos de aprendizagem. (AMARAL, 2011; MITJÁNS MARTÍNEZ, 2009b, 2012a, 2012b). Dessa maneira, com o intuito de compreender as possibilidades da utilização do aprendizado criativo emergir em diferentes contextos, para além do contexto original, nãoformal, faz-se necessário o entendimento dos conceitos de impacto, a mudança e o desenvolvimento da subjetividade. No entanto, é oportuno ressaltar que, à diferença da Teoria da Subjetividade em si, no entanto, esses temas têm sido objeto de pesquisas mais recentes e exigem ainda maior amadurecimento teórico (ROSSATO, 2009; SILVA SANTOS, 2010; AMARAL, 2011). A seguir, situamos a concepção de desenvolvimento humano a partir do enfoque histórico-cultural e da subjetividade, conforme proposta por González Rey. Por fim, abordaremos as diferentes nuances entres os processos de impacto, mudança e desenvolvimento da subjetividade.

\subsubsection{O Desenvolvimento da Subjetividade}

Para González Rey, o estudo do desenvolvimento humano centrou-se historicamente no estudo do desenvolvimento de funções como habilidades e processos cognitivos; segmentouse, assim, o desenvolvimento em diferentes áreas tais como o desenvolvimento intelectual, desenvolvimento moral, sexual, profissional. $\mathrm{O}$ autor se contrapõe a essa tendência, partindo 
das ideias de Vigotski sobre o desenvolvimento como processo integral da psique altamente singular e personalizado. (GONZÁLEZ REY, 2011) Aponta duas categorias apresentadas por Vigostki que impactam, de forma particular, a compreensão sobre o desenvolvimento humano: a situação social de desenvolvimento e a vivência (perizhivanie). Por situação social de desenvolvimento, Vigotski referia-se à combinação especial entre processos internos de desenvolvimento e as condições externas do meio. Combinação essa que condiciona novas formações psicológicas de desenvolvimento psíquico. (GONZÁLEZ REY, 2009a; BOZHOVICH, 1985) Por vivência (perizhivanie), Vigostki referia-se a uma unidade psíquica da situação social de desenvolvimento, correspondente à forma como indivíduo subjetiva sua experiência a partir de suas vivências emocionais e à forma como esse processo de subjetivação influencia seu desenvolvimento. Para González Rey, por meio dessas categorias, Vigotski supera a relação direta, linear e imediata entre os processos internos e o meio externo. (GONZÁLEZ REY, 2009a, 2011).

González Rey desenvolverá suas ideias a partir dessa matriz, apontando o desenvolvimento como processo engendrado por configurações de sentido subjetivo. Em sua proposta teórica da psique enquanto sistema subjetivo, o desenvolvimento é tomado, pelo autor, como um "processo integral do sujeito, que compromete, de forma simultânea, diferentes formações da personalidade em configurações de sentido que implicam o crescimento da pessoa em variadas esferas de sua vida” (GONZÁLEZ REY, p. 20).

Nesta acepção, o desenvolvimento da subjetividade implica mudanças qualitativamente diferenciadas nas configurações subjetivas da pessoa, originadas a partir da implicação do indivíduo em um determinado momento de sua atuação. Tais mudanças engendram novas configurações subjetivas que, como novos repertórios psicológicos, serão produzidas em outros momentos e espaços de sua vida. Uma criança que tome aulas de música poderá, assim, desenvolver configurações de sentidos subjetivos relacionadas à sensibilidade artística, à autoria, ao respeito ao método e à técnica, que perpassariam o momento da aula em si, para serem produzidos em outros momentos de sua vida. $\mathrm{O}$ mesmo poderia ocorrer para uma criança que aprenda judô ou qualquer outra prática esportiva e que mobilize produções subjetivas relacionadas a essa atividade em outros contextos de sua vida. Produções subjetivas relacionadas, como por exemplo, ao respeito mútuo, à competição, à consciência corporal, entre outros. 
Outro exemplo muito significativo e bastante citado por González Rey é a aprendizagem da leitura e da escrita como unidade subjetiva de desenvolvimento. Frequentemente tomada como o desenvolvimento de uma habilidade, esta aprendizagem, em muitas crianças, pode relacionar-se a construções emocionais de autoestima e autoconfiança, assim como promover a socialização e a criatividade, de forma a transcender habilidades cognitivas ou motrizes e influir em seu desenvolvimento integral. (GONZÁLEZ REY, 1999a)

O desenvolvimento da subjetividade associa-se, assim, às formas próprias de organização e de processualidade do sistema subjetivo; à tensão entre as configurações da personalidade e as configurações e sentidos subjetivos que permanentemente emergem no curso da ação. Um movimento em que novas configurações subjetivas se organizam como recursos subjetivos para o indivíduo, em contextos diversos de sua vida.

Considera-se, assim, uma concepção de desenvolvimento da psique humana que deixa de ser compreendida como um processo de aquisições próprias de etapas universais, para tornarse um processo integral do sistema psíquico, que compromete configurações de sentido subjetivo, que implicam o crescimento da pessoa em variadas esferas de sua vida. (GONZÁLEZ REY, 2005a)

González Rey $(1995 ; 1999$ a) sugere três forças motrizes para o desenvolvimento: as interações entre os sentidos subjetivos atuais com configurações subjetivas da personalidade_ denominadas unidades subjetivas de desenvolvimento; o papel das contradições e a comunicação.

Com relação às unidades subjetivas de desenvolvimento, González Rey afirma (2011, p.55, tradução nossa)

Há uma tensão entre as configurações da personalidade e as configurações subjetivas que permanentemente emergem no curso da ação que é de grande importância para o desenvolvimento humano. A partir desta tensão, um novo sentido subjetivo aparece, gerando novos repertórios psicológicos que levam a novas configurações psicológicas a partir das quais a pessoa, como sujeito deste processo, toma novas decisões e novos caminhos no curso de sua experiência de vida".

$\mathrm{Na}$ citação acima, a tensão refere-se à forma pela qual o sujeito subjetiva as situações vivenciadas e como essa subjetivação impacta seu sistema subjetivo. Segundo o autor, esse 
nível de impacto pode engendrar mudanças nas configurações personológicas, configurando desenvolvimento. Esses níveis de impacto no sistema subjetivo, ou as unidades subjetivas de desenvolvimento, não consistem um conjunto de aquisições próprias de etapas universais, senão a momentos concretos da vida dos indivíduos. Várias unidades subjetivas de desenvolvimento podem coexistir para a pessoa em um dado momento de sua vida. Essa compreensão permite perceber o desenvolvimento da psique humana como um processo integral, altamente singularizado (GONZÁLEZ REY, 1999a).

Com relação às contradições do indivíduo como forças motrizes de desenvolvimento, González Rey sugere que a forma como a pessoa, ativamente, se relaciona com suas próprias configurações personológicas é um processo importante para o desenvolvimento. São exemplos desse aspecto as contradições entre o sistema de representações pessoais de um sujeito e o conjunto de emoções que possivelmente emergem em oposição a essas representações (GONZÁLEZ REY, 1999a, 2004, 2005a, 2005c, 2007). Poderíamos citar como exemplo prático de tal situação o indivíduo que fuma ou que pratica maus hábitos alimentares e que, no entanto, tem uma representação de saúde diferenciada dessas práticas.

Se, por um lado, tais contradições podem consistir fontes de transtornos psicológicos, por outro podem constituir fontes de desenvolvimento na medida em que o sujeito tem alguma consciência delas e ativamente atua para resolvê-las. Torna-se relevante, assim, o papel ativo do sujeito em seu próprio processo de desenvolvimento, aspecto tradicionalmente não explorado pela literatura da área em que aquisições de habilidades ou determinações externas são tomadas como os fatores determinantes de desenvolvimento. (GONZÁLEZ REY, 1999a)

Por fim, o papel da comunicação como força motriz de desenvolvimento, relaciona-se ao permanente envolvimento da subjetividade no processo complexo de comunicação presente em grande parte das interações sociais de um indivíduo. Ressalta-se, por esse aspecto, o potencial de um dizer ou de um diálogo em acarretarem uma produção subjetiva, plena de emoções e significados, que implique mudanças no sistema subjetivo e novas configurações que deverão se refletir nas ações do indivíduo em outros momentos e espaços de atuação. Recupera-se, novamente, o papel do sujeito ativo em seu processo de desenvolvimento.

Assumir o desenvolvimento psicológico como um processo engendrado por mudanças no sistema complexo, dinâmico e aberto da subjetividade acarreta esclarecer as diferentes nuances entre o impacto, a mudança e o desenvolvimento da subjetividade. 


\subsubsection{Impacto, Mudança e Desenvolvimento da Subjetividade}

A mudança da subjetividade inscreve-se em sua movimentação constitutiva, enquanto sistema complexo, dinâmico e aberto. A subjetividade está sempre em movimento, em processo de devires e mudanças, embora nem toda mudança seja caracterizada como desenvolvimento. Sobre mudanças na subjetividade, González Rey (2007, p. 138) coloca

As configurações subjetivas expressam a organização subjetiva do sujeito, a qual é constituinte de todas as suas ações, ainda que os novos sentidos subjetivos surgidos no curso da ação não estejam contidos nessa organização subjetiva a priori. Esses novos sentidos subjetivos entram na organização da configuração atual e, nela, podem levar a uma série de mudanças que terminem transformando a própria organização [...]

A partir da citação anterior, percebemos que a mudança é própria do fluxo autoorganizativo do sistema subjetivo, uma vez que é engendrada por novos sentidos subjetivos produzidos no curso da ação do indivíduo. Esses novos sentidos subjetivos, por sua vez, são produzidos mediante impactos gerados pelas relações com outros sistemas subjetivos individuais e sociais e pelas experiências vivenciadas em diferentes contextos. Impactos referem-se, portanto, a cada momento em que, por tensões ou contradições com o sistema subjetivo atual, novos sentidos subjetivos são produzidos a cada momento de experiência de vida do indivíduo. (GONZÁLEZ REY, 2007; SILVA SANTOS, 2010)

O desenvolvimento da subjetividade, por sua vez, implica uma mudança qualitativamente diferenciada; uma mudança que, como vimos, acarreta em novas configurações subjetivas, mais estáveis na produção subjetiva do indivíduo, e que se refletem em sua atuação em contextos e momentos diversos de sua vida. $\mathrm{O}$ desenvolvimento da subjetividade associa-se, assim, às formas próprias de organização e de processualidade do sistema subjetivo. Ou, conforme Rossato (2009) aponta, associa-se à permanente relação entre a subjetividade social, o sujeito e sua personalidade.

Em sua pesquisa, Silva Santos (2010) analisa o impacto na subjetividade individual de professores do primeiro contato com alunos com desenvolvimento atípico. Em sua análise, conclui que diferentes níveis de mudanças podem ocorrer a partir das diferentes produções subjetivas dos professores desencadeadas pelos contatos com os alunos. Entre eles, a mudança 
significativa, a mudança pouco significativa e a mudança não significativa. Conclui que a produção subjetiva, gerada conforme o maior ou menor envolvimento emocional com os alunos, e a forma como essa produção se articula com a subjetividade social da escola (no que concerne a questões de inclusão) podem favorecer ou dificultar a constituição de mudanças significativas.

Os estudos de Silva Santos oferecem um novo olhar sobre a forma como diferentes momentos e contextos da vida do indivíduo podem contribuir para processos de impactos, mudanças e desenvolvimento da subjetividade. Em concordância com a autora, assumimos que, seja em contexto formal ou não-formal, as situações de aprendizagem, como momentos de produção de sentidos subjetivos, podem contribuir para tais processos. Na próxima seção, discutiremos mais detalhadamente a aprendizagem e sua dimensão subjetiva.

\subsection{A Dimensão Subjetiva da Aprendizagem}

O campo da psicologia da aprendizagem esteve historicamente caracterizado pela prevalência da psicologia empírica descritiva, orientada mais ao estudo de elementos e operações específicas que participam do processo de aprender, tais como processos lógicos, cognitivos, comportamentais e intelectuais, do que à compreensão da aprendizagem como expressão da psique enquanto sistema. (GONZÁLEZ REY, 1998; MITJÁNS MARTÍNEZ, 2009b; MITJÁNS MARTÍNEZ, 2012a; MITÁNS MARTÍNEZ e GONZÁLEZ REY, 2012b)

Para González Rey, a forma como o tema da cultura foi concebido, em diferentes abordagens da psicologia, desde Bruner a Rogoff, como dimensão a ser direta e linearmente interiorizada pelo indivíduo, privilegiou a concepção da aprendizagem como processos aquisição de significados culturais em processos de organização e reorganização cognitivas (GONZÁLEZ REY, 2009, 2008, MITJÁNS, 2012b). Como apontado nas seções anteriores, esta lógica linear e determinista do social e do cultural na psique humana esteve igualmente presente no próprio pensamento de Vigotski, em sua fase mais objetivista caracterizada pelos conceitos de interiorização, mediação semiótica, e nas perspectivas cultural-histórica e da atividade (GONZÁLEZ REY, 2010a). Esta lógica acarretou inúmeras consequências às atividades educacionais entre outras, o destaque à importância dos conteúdos, a concepção assimilativo-reprodutiva do conhecimento, o caráter instrumental da mediação pedagógica. 
A consideração da aprendizagem como processo do sistema da psique, busca superar esta lógica da relação direta e determinista entre o social e o individual, o externo e o interno, ao considerá-lo como sistema produtivo e gerador, a partir do reconhecimento da união inseparável entre a emoção e o simbólico. Conforme González Rey (2009) afirma o desenvolvimento psíquico é social apenas em sua gênese pois, logo, o pensamento passa a ser uma função ativa do sujeito; um sujeito que pensa como "um momento vivo e complexo de expressão de toda a sua subjetividade" (pg.129). Com esse entendimento, a aprendizagem e a significação das ideias passam a serem vistas, não como operações lógico-formais, mas como produções subjetivas.

Considerar a dimensão subjetiva da aprendizagem implica inscrevê-la neste sistema, tendo em conta os processos emocionais que participam e se desenvolvem no decorrer do processo de aprender, tanto para favorecê-lo quanto para dificultá-lo. Estudos sobre a subjetividade e a aprendizagem têm evidenciado essa união entre o emocional e o simbólico, em momentos de implicação subjetiva do aprendiz. Rossato (2009) considera a dimensão subjetiva na superação das dificuldades de aprendizagem escolar. Mitjáns Martínez (1997, 2009b, 2012a, 2012b) e Amaral (2011) consideram a criatividade na aprendizagem enquanto expressão do sistema subjetivo no processo de aprender. Oliveira (2010) aponta inter-relações entre o subjetivo e a seleção e uso de estratégias de aprendizagem pelos aprendizes.

Ter em conta a constituição e a dinâmica da produção subjetiva do indivíduo que aprende nos permite a compreensão da aprendizagem como um processo altamente singular e complexo deste indivíduo. Na aprendizagem escolar, por exemplo, vimos que participam da configuração subjetiva da ação do aprender do aluno, múltiplos sentidos e configurações subjetivas associados a diversas outras esferas de sua vida que, por sua vez, se expressam no curso das experiências vividas em sala de aula. (GONZÁLEZ REY, 2012)

No processo de aprender, no entanto, a trama complexa de sentidos subjetivos e configurações subjetivas se movimenta na relação tensa com novos sentidos subjetivos produzidos no curso da ação do aprender. Neste movimento, novas produções subjetivas podem, ao se constituírem como unidades subjetivas de desenvolvimento, engendrar novas configurações da personalidade. (MITJÁNS MARTÍNEZ, 2012b).

Como vimos na seção anterior, a aprendizagem da leitura, por exemplo, é uma aprendizagem que, devido ao significado da leitura em nossa sociedade, pode mobilizar uma 
produção subjetiva que se transforma em recurso subjetivo ao ser mobilizada em outros momentos e espaços onde a leitura se faz necessária, para além do momento da aprendizagem em si, configurando-se como desenvolvimento. (GONZÁLEZ REY, 2005a)

Considerar a dimensão subjetiva na aprendizagem implica ter em conta, que processos do aprender se constituem como processos simbólico-emocionais, implica ainda considerar que é precisamente o caráter das configurações subjetivas e sentidos subjetivos produzidos no curso do aprender o que organiza o subjetivo para a aprendizagem e define a "qualidade" desta para o aprendiz. (GONZÁLEZ REY, 2005a; MITJÁNS MARTÍNEZ, 2012a, 2012b).

Nem todas as aprendizagens envolvem implicação emocional e, portanto, subjetiva. Em especial, as aprendizagens mecânicas e reprodutivas tão comuns no contexto escolar. Ao mesmo tempo, a implicação emocional pode acontecer em qualquer tipo de aprendizagem: do memorístico e reprodutivo aos tipos mais complexos de aprendizagem compreensiva e criativa, onde ela deve acontecer.

Conforme apresentado no capítulo anterior, estudos na área da educação não-formal e, mais especificamente da aprendizagem em museus, tem evidenciado o voluntarismo, a motivação para a aprendizagem, a livre escolha na atenção e seleção dos conteúdos como alguns dos aspectos que caracterizam esta aprendizagem (SCHAUBLE, LEIDNHARDT e MARTIN, 1997; FALK, 1999; FALK e DIERKING, 2000). A perspectiva teórica da subjetividade nos permite a compreensão de que tais aspectos se conformam como expressões do sistema subjetivo. Na aprendizagem não-formal, ao tomar uma visita ao museu ou ao zoológico, por exemplo, podemos supor que as escolhas pessoais sobre o que ver, o que experimentar, quais informações ler, entre outras, ocorrem em meio a produções subjetivas que permeiam a experiência da visita e constituem aprendizagens neste contexto. Na próxima seção, aprofundaremos essa reflexão sobre o papel dos contextos no processo de aprendizagem, abordando a temática do Outro sob a perspectiva teórica da subjetividade.

\subsection{O papel do social e a dimensão do Outro na aprendizagem}

O reconhecimento do caráter histórico-cultural da psique humana remete à compreensão da aprendizagem escolar e da aprendizagem museal como um processo de natureza social sem que isso implique, conforme já apontado, que este social se expresse no indivíduo de forma 
direta e linear. A consideração da aprendizagem como processo da subjetividade presume que o caráter social da aprendizagem pode se expressar de múltiplas formas. Entre elas, de forma ilustrativa, apontamos três dimensões.

Em primeiro, a expressão do social na natureza dos conteúdos e habilidades que devem ser apreendidos. Esses conteúdos (expressos em conceitos e sistemas de conceitos) e habilidades (procedimentos de ação em relação aos conteúdos) são socialmente constituídos, representam produtos culturais diversos e, por sua própria natureza, participam na orientação das ações do aprendiz (TUNES, TACCA E MITJÁNS MARTíNEZ, 2006).

Cabe enfatizar que se na educação formal, escolar, tais conteúdos caracterizam-se tradicionalmente por ementas fechadas, organizadas rigidamente sob óticas disciplinares, no contexto não-formal há uma maior liberdade de seleção de temas e tratamento sob óticas mais transversais. Além disso, conforme já apontado, a ausência de processos avaliativos permite igualmente maior liberdade e autonomia por parte do aprendiz sobre o que aprender, quando e como.

Em uma segunda dimensão, o social expressa-se nas diferentes posições que o aprendiz ocupa na situação pedagógica. São exemplos dessa dimensão a forma como o aluno subjetiva a instituição e o espaço escolar, a representação que tem do professor e das atividades que lhe são solicitadas, suas expectativas de aprendizagem, a emocionalidade que caracteriza o clima da sala de aula, entre outros. No caso do contexto não-formal, a forma como o aprendiz subjetiva a instituição museal e o seu espaço físico, a representação que tem sobre ela, a emocionalidade que caracteriza o clima da participação em suas ações educativas, entre outros.

Por fim, uma terceira dimensão onde a expressão do social se reflete nas múltiplas e diferenciadas nuances da relação com o outro no processo de ensino e aprendizagem. Destacase, aqui, o outro dialógico, em sua condição de interlocutor ativo que, no processo de sua interação com o aprendiz, em sua constituição subjetiva singular, pode "provocar" neste aprendiz produções subjetivas que o implicarão emocionalmente e qualificarão a sua experiência. (GONZÁLEZ REY, 1999a; MITJÁNS MARTÍNEZ, 2004).

Enfatiza-se, assim, a dimensão relacional entre os indivíduos envolvidos na interação pedagógica. No ambiente escolar, a relação com o professor e com os colegas. No ambiente museal, a interação com as múltiplas vozes presentes na instituição museal, entre elas, a voz da exposição; a voz do monitor; a voz dos colegas e familiares durante a visita. 
Em todas essas três dimensões, o Outro participa da aprendizagem, não como um campo de atuação ou espaço simbólico, mas como um "social subjetivado", constitutivo do próprio aprendiz, organizador de seu sistema subjetivo, regulador de suas ações em contexto, e favorecedor, ou não, de sua implicação emocional no seu processo de aprender. Conforme González Rey (2004, p.10) aponta, “o outro é significativo no desenvolvimento da pessoa somente quando se converte em um sentido subjetivo, que está sempre associado à emocionalidade".

Assumir a aprendizagem e a construção de conhecimentos como processo da subjetividade implica assumir o social como aspecto constitutivo da subjetividade do aprendiz. Com base nesse entendimento, a presente pesquisa busca compreender a expressão da subjetividade social do contexto não-formal na organização subjetiva do aprendiz, por meio da análise da configuração subjetiva da ação do aprender deste aprendiz neste contexto. Busca, ainda, as relações dessa configuração subjetiva da ação do aprender para a possibilidade de ocorrência, ou não da aprendizagem criativa.

\subsection{A aprendizagem criativa}

A aprendizagem criativa, proposta por Mitjáns Martínez, faz referência a uma forma qualitativamente diferenciada de aprendizagem em que o aprendiz, em sua condição de sujeito, envida processos de personalização das informações, de confrontação com os dados a partir de perspectivas e pontos de vistas próprios e de geração de novas ideias que vão além do inicialmente posto. Por seus processos específicos, a autora aponta que ela se diferencia de outros tipos, entre os quais a aprendizagem reprodutiva, a memorística ou a compreensiva; tipos de aprendizagem mais comumente encontrados nos diversos níveis do nosso sistema educacional formal, historicamente orientado por um ensino homogeneizado, baseado na transmissão e reprodução de conhecimentos.

O conceito de aprendizagem criativa parte da concepção da criatividade como processo complexo da subjetividade humana, tomando a Teoria da Subjetividade de Fernando González Rey como seu arcabouço teórico. Dessa forma, veremos em primeiro, a concepção da criatividade subjacente à concepção da aprendizagem criativa. A seguir, discutiremos a aprendizagem criativa propriamente dita. 


\subsubsection{A criatividade como processo da subjetividade}

O interesse pela criatividade e seu desenvolvimento tem aumentado em nossa sociedade atual, caracterizada entre outros aspectos, pelo rápido avanço das tecnologias digitais e pela crescente necessidade de formação de indivíduos capazes de gerar informação e conhecimento. Não obstante, diferentes enfoques teóricos e epistemológicos sobre as concepções de conhecimento e de sujeito acarretam diferentes abordagens a respeito da criatividade. Se abordagens que partem da concepção de um sujeito universal tenderam a conceber a criatividade como um dom, um potencial inato, cujo indivíduo possui ou não, a concepção de um sujeito biologicamente determinado tendeu a considerar a criatividade como um fenômeno intrapsíquico, individual, resultante de um insight único, isolado de um contexto social e cultural. Tais visões ainda que superadas pela ciência, estão presentes na subjetividade social e nos espaços e práticas educativas em geral.

O "boom" das pesquisas sobre a criatividade é historicamente associado aos estudos de J. P. Guilford, na década de 50. Seus estudos partiram da percepção, à época, da inadequação dos testes de QI para a predição de indivíduos criativos. Estimulada pelo contexto da Guerra Fria e altamente financiada pelo governo americano, a pesquisa buscava identificar traços de personalidade criativa a partir de testes quantitativos de pensamento divergente com o objetivo de capacitar indivíduos criativos em áreas estratégicas para os Estados Unidos. Na década de 60, os testes Torrance consistiram uma adaptação dos testes de Guilford a crianças. Ampliouse o objetivo das pesquisas sobre criatividade para o setor educacional como um todo, de forma a promover a formação de profissionais criativos, ainda para áreas estratégicas. Por volta dos anos 70, na chamada "revolução cognitiva", a promoção da criatividade deixa de ter como objetivo a formação de profissionais para ganhar a conotação de promover o bem estar e a saúde dos indivíduos. A pesquisa gradualmente preocupa-se menos em predizer a criatividade, mas entender melhor como ela se processa em diferentes domínios, considerando seus processos cognitivos subjacentes, as influências sociais a ela associadas e as questões específicas do campo onde a criatividade acontece. (FELDMAN, D.H.; CSIKSZENTMIHALYI, M.; GARDNER, H., 1994)

Destacam-se, assim, diferentes correntes teóricas e epistemológicas que buscam a compreensão desse fenômeno. As abordagens humanistas, expressas nas pesquisas de Maslow, 
sobre a criatividade autorrealizada, e de Carl Rogers, sobre a criatividade como momento da integralidade do sujeito, avançam na compreensão mais complexa da criatividade enquanto fenômeno conformado por aspectos cognitivos e afetivos. As abordagens cognitivistas expressas a partir das pesquisas de Amabile, na década de 80, informam a preponderância da motivação intrínseca sobre a extrínseca no processo criativo. Por fim, as abordagens sistêmicas, nos trabalhos de Gruber, Csikszentmihalyi e Gardner exercem grande influência no pensamento contemporâneo sobre o tema como um fenômeno resultante da integração entre os contextos social, pessoal e cultural. ${ }^{11}$

A partir desses trabalhos, amplia-se a compreensão do pensamento criativo. Com efeito, estudos contemporâneos sobre a criatividade tendem a enxergá-la como fenômeno sistêmico, multifacetado, plurideterminado, fruto da interação entre subsistemas relacionados ao campo, ao domínio e à pessoa. (FELDMAN, D.H.; CSIKSZENTMIHALYI, M.; GARDNER, H., 1994)

Não obstante, ao propor a criatividade, como processo da subjetividade humana sob uma perspectiva histórico-cultural, Mitjáns Martínez concebe uma visão diferenciada das pesquisas anteriormente citadas. Para a autora, o processo criativo não se dá em um sujeito universal, mas em um indivíduo concreto, constituído em contextos históricos, em relações sociais e em situações singulares de sua trajetória de vida. Indivíduo esse cuja relação com a realidade encontra-se mediatizada por sua produção subjetiva. (MITJÁNS MARTÍNEZ, 1997, 2002, 2008a, 2008b, 2012a)

Dessa forma, para a autora (1997), as abordagens humanistas tendem a não considerar o importante papel dos contextos históricos e sociais do indivíduo na sua constituição e em seu processo criativo. As abordagens cognitivistas, por sua vez, não conseguem superar a tendência teórica da separação entre a motivação e outras funções psíquicas, tais como o pensamento e

\footnotetext{
${ }^{11}$ Em sua pesquisa Gruber realiza um estudo de caso sobre o processo criativo de Charles Darwin no desenvolvimento de sua Teoria da Evolução, também na década de 80. Na análise meticulosa de cadernos e anotações de Darwin, Gruber conclui que o processo criativo, mais do que um grande insight isolado, emerge a partir de um árduo e contínuo trabalho intelectual, marcado por uma curiosidade persistente na resolução de um problema particular. Csikszentmihalyi, por sua vez, realiza sua pesquisa sobre a produção criativa de arte na Florença do século XIV que indicam uma conjunção de múltiplos aspectos sociais, tais como a reunião de grandes expertises, a promoção da competição e as condições econômicas favoráveis, que influenciaram e favoreceram uma das maiores concentrações de atividade criativa artística (FELDMAN, D.H.; CSIKSZENTMIHALYI, M.; GARDNER, H., 1994). Sua pesquisa aponta para a integração do contexto social e cultural ao processo criativo.
} 
personalidade. Segundo Mitjáns Martínez (1997), as pesquisas não vislumbram que “os motivos (intrínsecos e extrínsecos) estruturam-se em sistemas motivacionais complexos da personalidade [...]” (MITJÁNS MARTÍNEZ, 1997, p. 35).

E, por fim, as pesquisas de abordagem sistêmica, apesar da enorme contribuição para a ampliação da compreensão da criatividade como fenômeno que integra sistemas relacionados ao campo, ao domínio e à pessoa, ainda a tomam como resultante direta das interações entre elementos desses sistemas que dela participam. Ou seja, compreendem-na como diretamente determinada pela interação de múltiplos fatores.

De forma diferenciada a tais concepções, Mitjáns Martínez concebe a criatividade como expressão da subjetividade, em seu caráter gerador do novo e do valioso para um campo específico de ação humana. Em suas palavras (MITJÁNS MARTÍNEZ, 2008b, pg. 120),

A criatividade é um processo complexo da subjetividade humana na sua simultânea condição de subjetividade individual e social, que se expressa na produção de algo "novo" e "valioso" em um determinado campo da ação humana.

Em nossa opinião, duas novas e importantes contribuições decorrem da concepção de criatividade como processo complexo da subjetividade humana, conforme proposta por Mitjáns Martínez. Em primeiro, como já apontado, o entendimento de que a criatividade não é resultante de fatores contextuais que podem diretamente favorecê-la ou inibi-la. Como processo da subjetividade, a criatividade emerge de processos e produções subjetivas singulares ao indivíduo em sua constituição histórico-cultural.

Em segundo, o reconhecimento de que há diversos níveis de criatividade a depender de diferentes graus do "novo" e do "valioso"; e o reconhecimento de que esses critérios de novidade e valor são sempre relativos. Uma nova forma, mais rápida, de fazer uma receita culinária pode indicar uma expressão da criatividade na cozinha, estando o critério do "novo", relacionado aos novos procedimentos e o critério do "valioso", relacionado à maior eficiência e rapidez para a realização do prato. Uma nova forma de ensinar álgebra pode indicar a expressão da criatividade no trabalho pedagógico do professor, estando o critério do "novo" relacionado a nova forma de ensinar e o critério de "valioso" relacionado a sua pertinência para a aprendizagem dos alunos. De forma pioneira e diferenciada das concepções teóricas apresentadas, Mitjáns Martínez (2002, 2008a, 2008b, 2012a) assume que o "valor” do criativo 
não é dado, portanto, pelo julgamento de terceiros (ou pelo campo social conforme Csikszentmihalyi denomina), mas pela sua pertinência em relação ao campo de ação humana em que a expressão criativa acontece.

Em suas primeiras pesquisas sobre a criatividade, Mitjáns Martínez buscou entendê-la como expressão de configurações da personalidade. Configurações essas que, em sua função reguladora, desempenham papel substancial no comportamento criativo. Para ela, enquanto autores atribuem às capacidades da atividade criativa um papel determinante da conduta criativa, "esquecem que a conduta criativa é produzida por um sujeito que opera com suas capacidades, integrando-as num nível de regulação mais complexo: a personalidade" (MITJÁNS MARTÍNEZ, 1997, p. 58).

Mitjáns Martínez sugere que elementos psicológicos comumente associados ao comportamento criativo, tais como independência, flexibilidade, autoconfiança, motivação, entre outros, não consistem traços universais, mas formações complexas que se constituem por configurações subjetivas individualizadas no sujeito que cria. De forma a apontar tais elementos psicológicos como formações subjetivas singulares do indivíduo, a autora denomina-os como indicadores funcionais da criatividade (MITJÁNS MARTÍNEZ, 1997). ${ }^{12}$

Interessa, assim, não a identificação descritiva de um perfil criativo, mas especificamente, a compreensão de como o comportamento criativo emerge de configurações subjetivas personológicas do sujeito envolvido em uma atividade específica.

Ainda de forma a compreender o processo criativo como expressão de configurações dinâmicas e singulares de recursos psicológicos do sujeito, Mitjáns Martínez (1997) propõe a categoria configuração criativa, a qual se refere ao subconjunto de configurações da personalidade que intervém no processo criativo. Com a categoria, a autora sugere que a expressão criativa não equivale diretamente às configurações personológicas do sujeito, mas a um momento particular de integração dessas configurações. Enfatiza, assim, a dinâmica e a diversidade das configurações dos indivíduos criativos (MITJÁNS MARTÍNEZ, 1997).

\footnotetext{
12 Mitjáns Martínez (1995) aponta como elementos psicológicos da criatividade na aprendizagem: motivação, capacidades cognitivas, autodeterminação, autovaloração adequada, segurança, questionamento, reflexão e elaborações personalizadas, capacidade de estruturar o campo de ação e tomar decisões, capacidade de planejar e se propor metas e projetos, capacidade volitiva para orientação intencional do comportamento, flexibilidade e audácia.
} 
Em pesquisas mais recentes, a autora avançou para a compreensão da criatividade como a expressão da ação do sujeito cuja produção subjetiva se constitui na trama complexa das configurações da personalidade, dos sentidos subjetivos produzidos na ação e de sentidos subjetivos relacionados à subjetividade social do espaço onde o sujeito atua.

A expressão criativa aproxima-se, assim, das formas próprias de funcionamento do sujeito, "caracterizadas pela autonomia e pela singularidade no enfrentamento das exigências pessoais e sociais perante as quais está colocado” (MITJÁNS MARTÍNEZ, 2009a, p. 33).

Nesta orientação, Mitjáns Martínez tem dedicado especial atenção ao que denomina a dimensão funcional da criatividade, correlacionando-a a processos do próprio funcionamento da subjetividade em que a criatividade se apresenta seja como reestruturações e novas constituições de configurações subjetivas, seja como formas de funcionamento do sujeito psicológico. Com a dimensão funcional da criatividade, a autora busca enfatizar as formas de emergência da criatividade como expressão do funcionamento da subjetividade, em detrimento de buscar compreendê-la exclusivamente como um processo que necessariamente resulte em um produto criativo. (MITJÁNS MARTÍNEZ, 2009a, 2012a)

Em concordância com a abordagem de Mitjáns Martínez, a presente pesquisa busca compreender diferentes níveis e formas de expressão da criatividade na aprendizagem em contextos não-formais, entendendo-a como um processo complexo da subjetividade na atividade própria do aprender. A seguir, pontuamos como a autora conceitua aprendizagem criativa associando-a a um tipo complexo de aprendizagem articulada ao exercício da condição de sujeito, à produção de ideias novas e que rompem o que está posto, e a processos subjetivos específicos.

\subsubsection{Características e processos subjetivos constitutivos da aprendizagem criativa}

A categoria aprendizagem criativa, conforme elaborada por Mitjáns Martínez (1997, 2002, 2008a, 2009b, 2012a, 2012b), é desenvolvida a partir dos estudos da autora sobre a criatividade como processo da subjetividade e sobre a dimensão subjetiva dos processos de aprendizagem. Ao trazer a criatividade para a esfera da atividade de aprendizagem, a autora se 
refere à produção de algo novo e pertinente para o aprender, para o processo de apropriação de conhecimento.

Mitjáns Martínez parte da necessidade de qualificar uma forma diferenciada das formas reprodutivas, memorísticas e compreensivas de aprendizagem, mais tradicionalmente encontradas na educação escolar. A aprendizagem criativa refere-se a uma forma mais complexa de aprendizagem, caracterizada por produções subjetivas por meio das quais o aprendiz se converte em sujeito do seu processo de aprender e, de uma forma implicada nesse processo, incorpora e produz conhecimento de forma personalizada, ativa e criativa.

Para a autora, dois importantes precedentes para a qualificação da aprendizagem criativa, na produção científica na área da aprendizagem, são as concepções de aprendizagem significativa em Ausubel e em Rogers (MITJÁNS MARTÍNEZ, 2008a). Mitjáns reconhece em Ausubel, processos de personificação da informação e de criação, em suas ideias de significado psicológico e produção de proposições, que qualificam de forma diferenciada a aprendizagem significativa; e que se aproximam, com independência da visão cognitivista de sua obra, da aprendizagem criativa.

Sob a matriz humanista, por sua vez, o pensamento de Rogers igualmente se aproxima da aprendizagem criativa quando considera a aprendizagem significativa como aquela em que o aprendiz encontra-se envolvido de forma integral, em aspectos cognitivos e sensitivos. A concepção rogeriana da aprendizagem avança para qualificá-la como processo de implicação emocional.

Para a Mitjáns Martínez (2012b), a aprendizagem criativa se distingue de outros tipos de aprendizagem por, no mínimo, três características, a saber: (1) a personalização da informação, relacionada à forma pela qual a informação se integra à subjetividade do aprendiz; (2) a confrontação com o dado, relacionada ao questionamento, à não aceitação do dado como verdade única, o que permite ao aprendiz identificar incongruências, lacunas e contradições; e, (3) a produção de ideias próprias e "novas", relacionada à transcendência do dado, a ir além do que está posto e construir novas relações.

Como emergente de uma produção subjetiva qualitativamente diferenciada, Mitjáns Martínez pontua, com base em suas pesquisas na área, alguns de seus processos subjetivos constitutivos. Entre eles: 
1) O exercício da condição de sujeito no processo de aprendizagem em seu caráter gerador, de ruptura e de subversão/transcendência em relação ao dado.

Mitjáns Martínez busca enfatizar aqui não o caráter ativo do sujeito aprendiz, da forma como o assumem abordagens construtivistas que enfatizam a ação e o protagonismo do sujeito em uma ação sobre o meio. Refere-se, sim, ao caráter autônomo, ativo e reflexivo do aprendiz na elaboração e geração de ideias próprias, determinado por sua capacidade de transcendência à informação ou dado que lhe é ensinado. Segundo Mitjáns Martínez (2012a, pg.100),

A essência da aprendizagem criativa é que, junto à compreensão, se expressa o caráter gerador do sujeito na produção de ideias próprias, hipóteses alternativas, imagens, etc que vão muito além da compreensão.

2) A produção de sentidos subjetivos favorecedores de geração de novidade que recursivamente "alimentam" essa forma de aprender.

A autora reconhece como premissa que o pensamento, em si, não acontece de forma neutra, dissociada de emoções que o indivíduo produz no próprio processo de pensar. No entanto, aponta que, na aprendizagem criativa, a produção subjetiva marcada pela forte implicação como processo de aprendizagem e o aprendizado criativo recursivamente constituem processos motivacionais que favorecem novas incursões em processos do aprender.

3) Atualização de configurações subjetivas diversas entre as quais parece se destacar a aprendizagem como configuração.

Pesquisas sobre a criatividade na aprendizagem, na perspectiva da subjetividade, têm indicado que alunos criativos tendem a apresentar comumente a aprendizagem como configuração subjetiva (AMARAL, 2011; AMARAL e MITJÁNS MARTÍNEZ, 2009; MITJÁNS MARTÍNEZ, 2009b, 2012a). Tomando as configurações subjetivas como produções mais estáveis, conformadas na trajetória de vida e nos espaços de atuação do indivíduo, a aprendizagem como configuração relaciona-se à representação e ao sentido que, de uma forma geral, a aprendizagem tem para o indivíduo. 
Desenvolver a aprendizagem como configuração subjetiva implica desenvolver uma condição subjetiva que favorece a motivação de incorrer em processos de aprendizagem de forma mais espontânea e autodeterminada.

4) Aspectos operacionais da aprendizagem aparecem subjetivados.

Esta característica da aprendizagem criativa refere-se à indicação apontada pelas pesquisas (MITJÁNS MARTÍNEZ, 2009a; MITJÁNS MARTÍNEZ e GONZÁLEZ REY, 2012; OLIVEIRA, 2010) de que aspectos operacionais de aprendizagem, tais como estratégias de aprendizagem não se encontram dissociados da própria produção subjetiva do sujeito que aprende. Em outras palavras, o sistema subjetivo não é a base (em separado) a partir da qual o aprendiz desenvolve ações de seleção e o uso de estratégias; o subjetivo constitui as estratégias de aprendizagem, que emergem como expressão da produção subjetiva da ação da aprendizagem criativa.

Cabe ressaltar que as características descritivas, que buscam tipificar a aprendizagem criativa (ou seja, a personalização da informação, a ruptura com o dado e a geração de ideias), são, em si, processos subjetivos. Portanto, a divisão da nomenclatura "características" e "processos subjetivos" não se sustenta com relação a natureza dos aspectos levantados, e sim, e tão somente, quanto às diferentes funções de cada um desses aspectos.

Pesquisas sobre a aprendizagem criativa têm enfatizado a pouca frequência deste tipo de aprendizagem nas instituições do nosso sistema educacional formal, que pela forma como se constituiu historicamente, caracterizou-se e caracteriza-se por uma educação massificada, homogeneizante, orientada para a concepção assimilativo-reprodutiva do conhecimento. (MITJÁNS MARTÍNEZ, 1997, 2008a, 2009b; AMARAL, 2011). De uma forma geral, prevalecem formas mais simples de aprendizagem focadas na memorização, na reprodução, ou até mesmo na compreensão dos conteúdos; em oposição ao pensamento criativo, em sua natureza autônoma, transgressora, subversiva, não é favorecido.

Conforme Mitjáns Martínez e González Rey (2012, p.94) colocam, “as formas mais complexas de aprendizagem não se opõem a outras formas mais simples, porém as integram”. Reconhece-se o valor da aprendizagem memorística, da reprodutiva, ou da compreensiva (esta 
última inclusive como importante processo da aprendizagem criativa); enfatiza-se, no entanto, o caráter qualitativamente diferenciado da aprendizagem criativa tendo em vista a produção criativa do aluno e o tipo de produção subjetiva que a constitui. Trata-se, portanto, não de um esforço teórico de tipificar ou classificar níveis de aprendizagem, mas de conceituar e compreender os aspectos constitutivos e os processos específicos que envolvem a mobilização de recursos psicológicos que permitem a criatividade na aprendizagem emergir.

Para a autora, apesar de tão pouco estimulada na instituição escolar, esta aprendizagem deveria ser priorizada por no mínimo duas razões: (1) a estabilidade do aprendido e suas possibilidades de transferência a novos contextos; (2) o seu potencial como unidade de desenvolvimento da condição de sujeito no processo de aprender ou em alguma atividade que o aprendiz desenvolva (MITJÁNS MARTÍNEZ, 2012c).

Conforme já mencionado, pesquisas, até então, têm se concentrado exclusivamente no contexto formal, seja no nível da educação básica, seja no nível superior, marcado pela aprendizagem orientada ao domínio dos conceitos científicos, dispostos nos conteúdos curriculares e nas disciplinas que os integram (TUNES, TACCA E MITJÁNS MARTÍNEZ, 2006).

Acreditamos que alguns dos processos subjetivos apontados pelos estudos refletem tipicamente a aprendizagem nesses contextos. Citamos, em especial, a personalização da informação, que pressupõe a informação de conteúdos oferecidos na situação de ensino, e a expressão subjetivada dos processos operacionais da aprendizagem, que pressupõe, na forma como tem sido estudada, a rotina sistemática e metódica de estudo individual.

Ao focar o contexto não-formal, a presente pesquisa busca avançar na compreensão da aprendizagem criativa de maneira a confirmar se as características e processos subjetivos constitutivos, já apontados pelas pesquisas em contextos formais, se apresentam igualmente, ou não, em contextos não-formais de aprendizagem, tipicamente menos estruturados. 


\section{CAPÍTULO III- METODOLOGIA DA PESQUISA}

\subsection{Objetivo}

O objetivo geral de nosso trabalho de pesquisa consiste em compreender a configuração subjetiva da ação do aprender e formas de expressão da aprendizagem criativa em um contexto de educação não-formal.

De forma a alcançar tal objetivo, o caminho de pesquisa considerou dois objetivos específicos:

1. Caracterizar a configuração subjetiva da ação do aprender da participante no contexto não-formal

2. Analisar formas de expressão da aprendizagem criativa no contexto não-formal em suas inter-relações com a configuração subjetiva da ação do aprender produzida neste contexto.

Por sua dimensão como estudo da subjetividade, a pesquisa utiliza como referencial epistemológico e metodológico, a Epistemologia Qualitativa, conforme desenvolvida por González Rey (1997, 2002, 2005b).

\subsection{A Epistemologia Qualitativa}

Para empreender estudos sobre um objeto tão complexo e plurideterminado como a subjetividade, González Rey desenvolveu, para além de um caminho metodológico, um referencial epistemológico específico para o campo, ao qual denomina Epistemologia Qualitativa (GONZÁLEZ REY, 1997, 2002, 2005b). O autor baseia a Epistemologia Qualitativa em três pilares: o caráter construtivo-interpretativo do conhecimento, a legitimação do singular como instância de produção do conhecimento científico e, por fỉm, a comunicação e o diálogo como norteadores da organização instrumental da pesquisa de forma a propiciar situações que promovam a produção subjetiva de seus participantes. 
Compreender o caráter construtivo-interpretativo do conhecimento implica compreender o conhecimento como produção e não como apropriação linear de uma realidade que se apresenta. A construção do conhecimento, portanto, se dá como um processo eminentemente teórico, que não necessariamente encontra associações diretas em referenciais empíricos. O conhecimento é, pois, uma construção do pesquisador, ou mais especificamente, uma construção de modelos compreensivos da realidade (GONZÁLEZ REY, 1999b, 2005b, 2005c). O segundo pilar, a legitimação do singular como instância de produção do conhecimento científico decorre diretamente da compreensão do caráter construtivointerpretativo do conhecimento. Se o conhecimento é sempre uma construção-interpretativa sobre a realidade, as produções teóricas são sempre construções singulares, de sujeitos concretos, históricos e sociais e, como tais, são produções abertas, permanentes; que tomam novos rumos no curso das experiências e ações destes sujeitos (GONZÁLEZ REY, 2005b).

Reconhecer o caráter singular do processo de produção do conhecimento científico requer um novo olhar sobre o valor das informações que compõem o argumento científico. $\mathrm{Na}$ Epistemologia Qualitativa, a legitimidade da teoria não decorre da informação como dado empírico, mas naquilo em que a informação tributa à construção do modelo teórico realizada pelo pesquisador.

Por fim, a comunicação e o diálogo como norteadores da organização instrumental da pesquisa implicam reconhecer a pesquisa como um processo de interação dialógica que envolve momentos de implicação subjetiva dos participantes. Dessa forma, para além dos processos simbólicos organizados e recriados nos discursos sociais, a comunicação se torna uma via privilegiada para se conhecer os processos de produção e organização subjetiva dos participantes (GONZÁLEZ REY, 2005b).

O lugar atribuído à comunicação na Epistemologia Qualitativa supera uma tradição positivista de epistemologia da resposta, caracterizada por uma lógica descritiva de pesquisa e por um instrumentalismo padronizado. Na Epistemologia Qualitativa, a comunicação no processo de pesquisa vai oportunizando ao pesquisador a produção de um complexo tecido informacional a partir do qual ele construirá seu modelo teórico (GONZÁLEZ REY, 2005b). Dessa forma, a realização dos instrumentos de pesquisa é definida pelo próprio processo comunicacional e pelo curso das construções interpretativas do pesquisador, com o objetivo de 
promover situações de implicação emocional que favoreçam a expressão subjetiva do participante e a possibilidade da construção, pelo pesquisador, de novas informações que o auxiliem na elaboração de seu modelo teórico.

Resgata-se, assim, o papel interativo e ativo do pesquisador no processo de produção de conhecimento. Processo esse caracterizado pela permanente construção teórica do pesquisador e pela flexibilidade e abertura do curso da pesquisa que, não acontece de forma pré-determinada ou linear, mas dentro de uma lógica configuracional de um sistema que inclui todas as subjetividades envolvidas.

No intuito de compreender a produção e a organização subjetiva do participante da pesquisa, o pesquisador busca sempre o que está para além do expresso ou diretamente observável. Elabora suas hipóteses por meio da construção de indicadores a partir do conjunto de informações que produz nos diferentes momentos da pesquisa. Necessário, portanto, ressaltar que indicadores não têm caráter absoluto ou conclusivo, mas são apenas uma unidade de significação no processo de interpretação e construção teórica.

\subsection{O Estudo de Caso}

Para compreender a configuração subjetiva da ação do aprender em um contexto nãoformal e suas inter-relações com a aprendizagem criativa neste contexto, realizamos um estudo de caso com alunos do ensino médio que participaram de uma ação educativa não-formal, conduzida por uma instituição museológica.

Sob a perspectiva da Epistemologia Qualitativa, em especial no que concerne à singularidade da pesquisa enquanto construção teórica do pesquisador, o estudo de caso adquire uma nova compreensão como proposta metodológica. Ao assumir o caráter construtivointerpretativo do conhecimento, o estudo de caso deixa de ser legitimado pela possibilidade de o caso singular, em abstrato, propiciar generalizações possíveis, e passa a adquirir valor a partir das formas próprias de construção e análise das informações pelo pesquisador, em sua busca por gerar novas zonas de sentido e, portanto, novas formas de inteligibilidade sobre o objeto estudado.

\subsection{A construção do cenário de pesquisa}


Sob a perspectiva da Epistemologia Qualitativa, os conceitos de campo e cenário da pesquisa consistem o espaço social que caracterizará o desenvolvimento da pesquisa e que se orienta para favorecer a abertura e o envolvimento dos participantes (GONZÁLEZ REY, 2005b). Ressalta-se, assim, esses conceitos como o espaço da ação criativa do pesquisador, considerando a multiplicidade e a processualidade dos elementos relacionais que o constituem. Em meio ao cenário da pesquisa, ao qual sua própria subjetividade se integra, o pesquisador vai construindo, de forma progressiva, a partir dos distintos elementos que considera relevantes, o seu modelo teórico sobre o problema estudado. O caminho da pesquisa se dá, portanto, em um contexto relacional dinâmico, singular e imprevisível, em que a pesquisa é construída dentro de uma lógica configuracional. (GONZÁLEZ REY, 2005b)

Na presente pesquisa, nossa aproximação inicial às participantes aconteceu em todo o decorrer de nossas atuações na ação educativa não-formal, doravante denominada como o Projeto. A significativa abertura dos organizadores do projeto e a grande acolhida de todos os envolvidos nos permitiram uma participação ativa em cada um dos encontros onde atuávamos nas dinâmicas, auxiliávamos na organização e convivíamos, em diversos momentos informais, com os nove participantes do Projeto e, entre eles, as três participantes da pesquisa. Nesse sentido, o decorrer da ação educativa constituiu, concomitantemente, (1) o processo de seleção das participantes, (2) momentos de observações e interações propícios à construção de informações para as elaborações teóricas sobre as subjetividades envolvidas, e, por fim, (3) o momento de preparação do cenário de pesquisa que nos permitiu a construção da relação de confiança e abertura entre o pesquisador e as participantes. Relação necessária para propiciar a intensa produção subjetiva que caracterizou os momentos dos instrumentos individuais posteriores aos seis meses de nossa atuação na ação educativa não-formal (GONZÁLEZ REY, 2005).

O primeiro instrumento individual (APÊNDICE A) consistiu ainda outro momento de construção do cenário da pesquisa na medida em que nele, ao contar uma historinha infantil selecionada, apresentamos brevemente nosso tema sobre a criatividade na aprendizagem e convidamos a participante a citar alguma atividade que se constitui como uma "paixão pessoal" e suas formas de aprender sobre essa "paixão".

Por nossas atuações no Projeto e por esse momento inicial, acreditamos termos desenvolvido um nível de aproximação, informalidade e comprometimento das três participantes da pesquisa que marcou todo o restante da pesquisa. 


\subsection{A seleção dos participantes da pesquisa}

O principal critério que orientou o processo de seleção dos participantes da pesquisa foi a busca por participantes que apresentassem indicadores funcionais de criatividade na aprendizagem durante os encontros do Projeto. Dessa forma, o processo de seleção ocorreu ao longo de todo o Projeto, com base em nossas observações de comportamentos associados à criatividade na aprendizagem, tais como a capacidade de realizar questionamentos, de elaborar críticas, de fazer associações, de pensar diferentes perspectivas, e em nossas análises sobre as produções intelectuais nas dinâmicas da ação educativa. O processo de seleção utilizou-se ainda de uma entrevista com os monitores do Projeto (APÊNDICE H), na qual as impressões de cada um dos monitores sobre características pessoais de cada participante, assim como de seus processos de aprendizagem no Projeto foram compartilhadas.

Foram selecionados quatro participantes, porém, por motivo de uma impossibilidade física de um dos participantes, este teve que ser desconsiderado. As três participantes restantes encontravam-se no último ano do ensino médio. Duas estudavam na mesma escola e se preparavam para realizar o vestibular para o ingresso no ensino superior. A terceira passou antecipadamente no vestibular da universidade federal mais próxima, e ingressou no ensino superior no meio da pesquisa.

\subsection{O campo de estudo}

De forma a compreender processos de produção e organização subjetiva na aprendizagem criativa em um contexto não-formal de aprendizagem, assim como as formas de expressão da aprendizagem criativa neste contexto, a pesquisa utilizou como estudo de campo uma ação educativa desenvolvida pela instituição F., em Brasília, orientada para o apoio ao Programa Saúde nas Escolas (PSE) ${ }^{13}$ em localidades específicas do Distrito Federal. Como uma iniciativa de divulgação científica, o Projeto previa uma série de encontros e atividades, de

\footnotetext{
${ }^{13}$ Instituído em 2007 pelo Decreto Presidencial no 6.286, o PSE consiste um programa do governo federal fruto de um esforço conjunto entre o Ministério da Educação e o Ministério da Saúde para o estabelecimento de ações de atenção à saúde de crianças e adolescentes escolarizados no Brasil. Pautado por diretrizes de intersetorialidade e de territorialidade, o programa tem por objetivo estabelecer uma rede territorial de cuidado integral em saúde a partir do planejamento e execução de ações articuladas entre comunidades escolares e unidades de saúde. O Projeto em questão se insere no âmbito o componente II do PSE, que discorre sobre a "Promoção e Prevenção em Saúde".
} 
outubro de 2012 a outubro de 2013, sendo destinado exclusivamente a alunos da rede pública de ensino.

Em sua inserção nas diretrizes da política pública federal, o Projeto objetivava o fortalecimento da participação dos jovens educandos nas ações e projetos do PSE em suas respectivas escolas, levando em consideração o ponto de partida do programa de considerar os saberes e as singularidades da comunidade escolar, representada por todos os atores que dela participam. Conforme contextualiza o projeto político pedagógico da ação educativa:

[...] A presente proposta objetiva o fortalecimento da implementação do PSE em três Regiões Administrativas do Distrito Federal; [...] a partir do apoio ao fortalecimento de participação dos educandos nos espaços de planejamento e realização das ações de promoção da saúde em ambiente escolar [...] É preciso desenvolver em cada um a capacidade de interpretar o cotidiano e atuar de modo a incorporar atitudes e/ou comportamentos adequados para a melhoria da qualidade de vida. [...]

[...] Lançamos então o desafio de sensibilizar e formar os jovens que fazem a sociedade, para que atuem como articuladores em suas comunidades escolares, fazendo parte efetiva do Programa Saúde e Prevenção nas Escolas.

Com esse objetivo de fortalecer a participação juvenil na implantação do PSE na escola, o Projeto viabilizou a contratação de nove bolsistas, estudantes de escolas públicas das regiões contempladas, para desenvolver atividades no período de um ano, de outubro de 2012 a outubro 2013. Os bolsistas foram selecionados por meio de processo classificatório com base na análise da Ficha Cadastro, incluindo um questionário autoavaliativo com índices de desempenho em aspectos como motivação/interesse; disponibilidade; participação em atividades curriculares; participação em atividades extracurriculares, e com base em entrevista. Conforme previsto no edital, no processo de seleção, especial atenção era dada a jovens com perfil de liderança, articulação dentro da comunidade escolar, motivação para execução das ações, interesse pelas questões de saúde e cultura, boa comunicação e conhecimento acerca das mídias sociais como ferramentas para a promoção do protagonismo juvenil.

Cabe ressaltar que o desempenho acadêmico não era um dos critérios utilizados na seleção dos bolsistas, sendo muitos deles alunos medianos, com experiências de reprovação de série ou de processos de recuperação. 
Por opção didática, apresentamos o Projeto em três de suas principais atividades previstas em sua proposta pedagógica:

1) O curso de Capacitação

Conforme o plano político pedagógico, o curso teve por objetivo capacitar os jovens a encontrar caminhos de intervenção na comunidade escolar, de forma a promover uma vivência saudável entre os diversos atores da comunidade contribuindo, assim, com os objetivos do PSE. Nesse sentido, o curso buscou trabalhar com os jovens bolsistas temáticas como o conceito ampliado de saúde, a história da saúde pública no Brasil, democracia, mídias e tecnologias sociais, buscando promover o desenvolvimento de capacidades para a atuação desses jovens como articuladores em suas respectivas comunidades escolares de forma a, em conjunto com ela, analisar os problemas, identificar causas e fatores, refletir e buscar soluções.

O curso conteve a carga horária de 40 horas-aula, presenciais, organizadas em sete módulos. Cada módulo era norteado por um tema gerador, com conteúdos teóricos e práticos. As aulas aconteciam nas dependências da instituição F., mas em diversos módulos foram organizadas visitas exteriores para a execução de atividades programadas, por exemplo, o Congresso brasileiro e as escolas dos bolsistas. O programa do curso consta no ANEXO I, da presente pesquisa.

\section{2) A aplicação e análise do Diagnóstico Rápido Participativo (DRP)}

Uma das principais atividades previstas para a participação dos bolsistas no projeto consistiu a realização do DRP- Diagnóstico Rápido Participativo ${ }^{14}$ na sua escola. No âmbito do projeto, a aplicação e a análise do DRP tinham como objetivos: (1) mapear os atores que realizam ações relacionadas à qualidade de vida dos jovens na região (quem são, o que fazem, se e como interagem entre si, como podem contribuir para o PSE); (2) Levantar questões pertinentes à saúde da "Comunidade Saúde na

\footnotetext{
${ }^{14}$ O DRP consiste em um conjunto de métodos participativos, orientados a permitir que uma população local "compartilhe, aumente e analise seus conhecimentos sobre a realidade, com o objetivo de planejar ações e atuar nesta realidade" (FARIA, A.C., 2006) A partir de ideias e princípios freirianos, o DRP utiliza-se de ferramentas de diálogo contribuindo para o conhecimento e a análise da realidade do local de acordo com a percepção dos habitantes locais, constituindo o ponto inicial para que as comunidades comecem a autogerenciar o seu planejamento e desenvolvimento de ações. (PICELLI, I., NICOLETTI, L., SEPÚLVEDA, L., no prelo)
} 
Escola" (escolares, profissionais de educação e saúde, familiares, educandos, e parcerias), revelando as prioridades locais.

As aplicações do DRP, consideradas para o âmbito dessa pesquisa, foram realizadas em duas escolas das regiões selecionadas pelo Projeto. As aplicações utilizaram como dinâmicas de grupos duas ferramentas de diálogo, a saber: a "Oficina de Imagens" e o "Mapa Falado". Os bolsistas realizaram as dinâmicas em duplas, cabendo a um bolsista o papel de apresentador e mediador, e ao outro o papel de relator.

As aplicações duraram em média entre uma hora e meia e duas horas, dirigidas a grupos de por volta de quinze pessoas, entre professores, coordenadores, alunos e funcionários da escola.

\section{3) O Fórum científico}

O Fórum científico consistiu um evento organizado pela Instituição F., em conjunto com os bolsistas, realizado nos dias 22 e 23 de agosto de 2013, com o objetivo de reunir os diferentes segmentos que compõem as comunidades escolares das localidades do DF, profissionais da saúde que atuam no território, pesquisadores e especialistas em um espaço dinâmico, horizontal, participativo e propositivo para discussão de questões referentes à saúde do escolar e de sua comunidade. Participaram do Fórum: educandos, educadores, gestores e outros trabalhadores da rede pública de ensino médio da Secretaria de Estado de Educação do Distrito Federal, e das referidas Regiões Administrativas e profissionais da Secretaria de Estado de Saúde do Distrito Federal.

No primeiro dia, a programação do Fórum (ANEXO II) previa a realização de mesas dialogadas sobre as seguintes temáticas (1) Saúde, Cidadania e juventude; (2) PSE e Alimentação Saudável: Perspectivas e desafios; (3) Qualidade de vida e Comunidade Escolar; (4) Violência e Vulnerabilidade Social. Neste dia, os bolsistas do projeto participavam como membros da mesa redonda apresentando a experiência da aplicação do DRP e os resultados de suas análises. No segundo dia do Fórum, aconteceram os grupos de trabalhos onde todos os participantes do evento, divididos em grupos para cada uma das referidas temáticas, discutiam 
medidas propositivas para as temáticas apresentadas. Neste dia, os bolsistas do projeto atuavam como mediadores e relatores dos grupos de trabalho.

O Fórum, portanto, constituiu importante espaço de divulgação das análises do DRP e de exercício da capacidade de atuação dos bolsistas como articuladores de grupos distintos orientados para a discussão de aspectos sobre a saúde nas escolas.

Articulação essa que, com o fim do projeto, previa-se continuada nas respectivas comunidades escolares com o desenvolvimento de ações continuadas nas escolas.

Nossas observações no Projeto aconteceram de maio a outubro de 2013, nos encontros quinzenais deste período, que totalizaram uma média de 73 horas (nos 19 encontros e no evento final do Fórum científico). Acompanharam, portanto, momentos do curso, da aplicação do DRP e do Fórum. Consideramos que a ação educativa do Projeto constitui um espaço pertinente para a pesquisa sobre a educação não-formal por várias razões. Em primeiro, pelo fato de haver sido idealizada por uma instituição, ocupada com ações educativas de divulgação científica, fora do sistema educacional formal.

Em segundo, por seu caráter "trans" institucional ao envolver, em sua execução, atores institucionais diversos, entre eles escolas, instâncias da Secretaria de Educação do Distrito Federal, grupos de especialistas da universidade, instituições relacionadas à divulgação científica em áreas relacionadas à saúde, associações comunitárias, permitindo um espaço efetivo de compartilhamento e construção conjunta de experiências e conhecimentos. Em terceiro, por não constituir uma ação educativa que se integra ao sistema formal, da escola de ensino médio, ou com qualquer programa de certificação como etapa do sistema oficial de ensino.

Por fim, em quarto, e como decorrência da terceira razão, por não considerar nenhum processo de avaliação de aprendizagem. Torna-se importante, aqui, esclarecer essa afirmação. Não havia, no Projeto, seja nas disposições do seu plano político pedagógico, seja no decorrer do trabalho pedagógico realizado, qualquer tipo de mensuração, de valoração, ou de classificação da aprendizagem, realizado de forma sistemática por um ator externo aos próprios aprendizes em si. A única exigência formal era a presença em, pelo menos $75 \%$ dos encontros e de realização das atividades previstas. Reconhecemos, no entanto, que no decorrer dessas atividades os participantes eram constantemente convidados a avaliar criticamente as atividades 
do próprio Projeto. Tais momentos, propiciavam, direta ou indiretamente, ricos momentos de auto-avaliação e, consequentemente, de aprendizagem. Ressaltamos, no entanto, que esses momentos não constituíam momentos de avaliação da aprendizagem, por parte dos organizadores do Projeto, em termos de mensuração, valoração, ou classificação dos participantes em relação ao aprendido. Em decorrência, não havia, por parte dos participantes do Projeto a subjetivação de um processo a avaliativo conduzido por um Outro, ou por um sistema de ensino, da forma como acontece em contextos formais.

Toda a avaliação da aprendizagem no Projeto era, de fato, conduzida pelo e para participante, considerando as relevâncias que cada informação, atitude, e experiência no Projeto, adquiriam em relação à realização das atividades previstas. Em especial, a aplicação e análise do DRP e a apresentação no Fórum.

Ao afirmarmos sobre a ausência de avaliação de aprendizagem apontamos, assim, para a ausência da avaliação de aprendizagem conduzida por um outro, muito embora processos de auto avaliação de aprendizagem fossem constantes. Nessa perspectiva, compreendemos que a avaliação da aprendizagem deixa de ter sentido em termos de garantir o acesso aos aprendizados, per se, mas passa a se constituir nas formas altamente singulares com que esses se associam ao que podem oferecer ao aprendiz em termo de possibilidades para a realização de algo. Aproximamo-nos assim da ideia de Carl Roger de que a avaliação tem que ter um sentido de "portas que se abrem" para possibilidades tendo em vista um determinado interesse do aprendiz.

A ausência de um sistema de avaliação externo favorecia, em muito a não orientação dos participantes para, no contexto do Projeto, buscar oferecer a "resposta certa" ou para atender demandas avaliativas. Em última instância, o compromisso dos participantes era com a realização das atividades de aplicação e análise do DRP, para as quais eram contratados como bolsistas, e que, por sua vez, também não eram formalmente avaliadas, senão informalmente na apresentação no Fórum

$\mathrm{Na}$ busca pela compreensão da aprendizagem criativa e pela caracterização das configurações subjetivas da ação do aprender das participantes no contexto não-formal, entendemos que as experiências dos participantes no contexto formal, como alunos das escolas 
de ensino médio, eram relevantes tendo em vista nossa perspectiva teórica. Dessa forma, para as três participantes, foram realizadas visitas e análises no contexto formal, nas seguintes formas:

- Camile: duas visitas a escola de ensino médio para conversas informais com professores e coordenação pedagógica; observações em sala de aula na universidade, em um total de 12 horas. A análise do contexto universitário aconteceu devido ao fato da aluna haver passado no vestibular em agosto, ainda antes de completar o terceiro ano do ensino médio.

- Estela e Mika: observações em sala de aula na escola de ensino médio, em um total de 6 horas, conversas informais com a equipe pedagógica da escola.

\subsection{Instrumentos e procedimentos de pesquisa}

A natureza construtivo-intepretativa do conhecimento e a característica processual e dialógica que caracterizam a pesquisa na Epistemologia Qualitativa implicam um novo entendimento sobre a natureza e a função dos instrumentos de pesquisa. Em contraposição a uma visão instrumentalista da pesquisa científica, reificadora da resposta enquanto dado empírico e do instrumento de pesquisa neutro, padrão e despersonalizado do pesquisador, os instrumentos de pesquisa, na Epistemologia Qualitativa, são tomados como indutores de expressão subjetiva no processo da relação entre pesquisador e participante. (GONZÁLEZ REY, 2005b)

Conforme já apontado, para González Rey (1999b, p.84), “o instrumento é uma ferramenta interativa, não uma via objetiva geradora de resultados capazes de refletir diretamente a natureza do estudado, independentemente do pesquisador". Nesta perspectiva metodológica, os instrumentos de pesquisa, como vias de expressão e comunicação, permitem a experiência de momentos singulares da relação pesquisador-participante, refletem a processualidade dessa relação e integram-se aos eixos de reflexão do pesquisador no contexto dessa relação. Um mesmo instrumento pode, assim, ser utilizado em diferentes momentos e produzir diferentes informações que serão interpretadas a partir dos caminhos da construção teórica do pesquisador.

A Epistemologia Qualitativa requer o processo da relação pesquisador-participante e requer, igualmente, o levantamento de uma ampla rede de informações com base na qual o 
pesquisador tecerá suas hipóteses e desenhará seu modelo teórico. Essa construção teórica é tramada a partir dos estados emocionais e das relações entre o dito e o não-dito, o expresso e o não-expresso, o entendido e o subentendido que perpassam os diferentes momentos interativos, propiciados pelos instrumentos da pesquisa.

No processo da pesquisa, buscamos, assim, assumir as características próprias desta perspectiva metodológica com relação à multiplicidade, à dinamicidade e à abertura dos instrumentos de pesquisa. Após as observações no contexto do Projeto, realizamos os instrumentos individuais e as observações no contexto formal. No decorrer da pesquisa, consideramos mudanças no plano previsto, retomando, por exemplo, o uso de informações de instrumentos prévios para iniciar as conversas nos momentos dos instrumentos seguintes e em momentos informais.

No curso da pesquisa, optamos, pelos seguintes instrumentos:

\section{Entrevistas como processo}

Compreendendo a natureza relacional da pesquisa na Epistemologia Qualitativa, tomamos as entrevistas não como momentos de levantamento de dados que compõem em si conteúdos de análise, mas como momentos de promoção de expressão subjetiva do participante que, ao serem analisados e interpretados pelo pesquisador em seu caráter processual, produzem as informações para a pesquisa. Nesse sentido, a qualidade das informações das entrevistas corresponde ao processo próprio da dinâmica relacional entre o pesquisador e o entrevistado, não só no processo de uma entrevista em si, como no curso das interações e entrevistas no decorrer da pesquisa. As informações levantadas pelas entrevistas não são, assim, analisadas de forma estática e independente; são analisadas como processo, a partir de entrecruzamentos de informações dos diferentes momentos a partir dos quais emergiram. Optamos por realizar quatro entrevistas semiestruturadas em momentos posteriores ao Projeto e comuns às três participantes selecionadas:

○ Entrevista semi-estruturada I: teve como principais eixos a história de vida, a relação com a família e com os amigos, hobbies, interesses e planos para o futuro (APÊNDICE B).

- Entrevista semi-estruturada II: teve como principais eixos a história de vida escolar, a relação com professores e colegas, a significação da educação escolar e da aprendizagem, a relação com o sistema avaliativo (APÊNDICE C). 
○ Entrevista semi-estruturada III: teve como eixo temático o uso de estratégias de aprendizagem (CABANACH et al, 2002) no contexto escolar (APÊNDICE E).

○ Entrevista semi-estruturada IV: com auxílio do portfólio do Projeto de educação não-formal elaborado pela própria participante, teve como eixos a motivação para a participação no Projeto, lembranças, momentos marcantes, e aprendizagens no Projeto (APÊNDICE F).

\section{Instrumentos apoiados em indutores escritos}

Segundo González Rey, um dos principais objetivos dos instrumentos escritos é "facilitar expressões do sujeito que se complementem entre si, permitindo-nos uma construção, o mais ampla possível, dos sentidos subjetivos e dos processos simbólico-emocionais diversos que caracterizam as configurações subjetivas do estudado" (pg.51). Para nossa pesquisa, optamos pelos seguintes instrumentos:

- COMPLETAMENTO DE FRASES: instrumento adaptado a partir de proposta de González Rey (1999b, 2005b), no qual indutores curtos são apresentados em formas de frases inacabadas para o participante completar (APÊNDICE D). Relacionados a questões gerais, ou a atividade, experiências ou pessoas na vida do participante, a quantidade e a frequência desses indutores permitem o deslocamento rápido do participante de um para o outro, favorecendo a expressão de sentidos subjetivos diversos. Conforme González Rey (2005b, pg.58) coloca,

as frases que formam o instrumento não definem seu valor pelo seu conteúdo explícito, pois mediante cada frase, cada sujeito pode expressar com independência, sentidos subjetivos muito diferentes daqueles que tais frases explicitamente sugerem.

O completamento de frases pode favorecer a construção de hipóteses sobre as configurações subjetivas do participante que deverão ser aprofundadas e enriquecidas ao longo do processo da pesquisa, no cruzamento das informações com os demais instrumentos (APÊNDICE D).

- REDAÇÃO: Para a pesquisa, a redação propôs o indutor temático sobre o tema da saúde, por sua centralidade no Projeto, e políticas públicas. Neste instrumento, apresentou-se o seguinte comando (APÊNDICE G): 
Considerando suas aprendizagens sobre saúde no Projeto e a polêmica sobre o Programa Mais Médicos, descrita no parágrafo abaixo, escreva suas reflexões sobre o seguinte tema:

\begin{abstract}
A recente polêmica em torno da vinda de médicos estrangeiros para o país reacendeu uma antiga e vasta discussão: os desafios da saúde pública no Brasil. Falta de médicos em regiões afastadas em contraponto à intensa concentração nas grandes cidades, ausência de estrutura nos hospitais da rede pública, além da dificuldade em conseguir atendimento no SUS são alguns dos inúmeros problemas que atingem os brasileiros diariamente. Mas quais caminhos nosso país deve percorrer para conseguir alterar essa realidade no Brasil?.
\end{abstract}

\begin{abstract}
A redação teve por objetivos (1) verificar aprendizados no Projeto com relação à conceitualização de saúde e (2) caracterizar o aluno em processos de autoria e personalização da informação que indiretamente expressam seu grau de compromisso e envolvimento reflexivo com o tema, indicando a produção de sentidos subjetivos sobre este. Nesta dimensão, a redação não é avaliada por seu conteúdo explícito, mas sim, pelos possíveis indicadores de sentido subjetivo que a narração pode oferecer (GONZÁLEZ REY, 2005b).
\end{abstract}

\title{
Observação
}

Compreendemos que a observação nos permite identificar comportamentos intencionais e não intencionais do participante nos espaços sociais em que se encontra que poderão ser relevantes no cruzamento com outras informações obtidas de outros instrumentos. Em nossa pesquisa, a observação aconteceu nos espaços envolvidos no tema da pesquisa: nos espaços da ação não-formal e no espaço escolar.

Nos espaços da ação não-formal, a observação contemplou, igualmente, o comportamento do participante com relação às relações sociais, com monitores e colegas, assim como suas participações. Buscamos roteirizá-la, a partir de três eixos:

(1) Com relação ao espaço e aos recursos. Onde se coloca com relação ao objeto e ao monitor; que recursos utiliza (caderno de anotações, câmera fotográfica, celular, Ipad, etc).

(2) Com relação às relações sociais. Como se relaciona com monitores; como se relaciona com colegas. 
(3) Com relação às participações. Grau de atenção; motivação para a realização das atividades; realização de perguntas interessantes e originais; posicionamentos e intervenções.

De forma a conhecer a trajetória do participante em outros contextos de aprendizagem, visando a produção de informações de possível relevância para a caracterização da subjetividade individual do participante, a pesquisa julgou pertinente a observação do participante no espaço escolar. Neste espaço, a observação igualmente contemplou o comportamento do participante tendo em vista as relações sociais, com professores e colegas, assim como à qualidade das participações nas aulas.

\section{Análise documental}

No processo de pesquisa, realizamos a análise documental em materiais diversos, com os objetivos de obtenção de informações sobre aspectos da vida acadêmica das participantes e análise de elementos indicadores de criatividade na aprendizagem:

○ No projeto de educação não-formal:

- o diário de bordo do Projeto: bloco de notas oferecido a todos os participantes para anotações de conteúdos e impressões de aprendizagem no decorrer dos encontros do Projeto;

- o portfólio do Projeto: documento solicitado a cada participante, ao final do Projeto, que consistiu, no caso das três participantes, em uma pasta com os registros pessoais, fotos e materiais dos momentos do Projeto por ordem cronológica;

- as produções da aluna nas dinâmicas realizadas.

Pelos mesmos motivos descritos no instrumento de observação, consideramos igualmente pertinente a análise de materiais relacionados à escola e às interações sociais mais gerais. Entre eles:

○ Na escola: boletins de notas, cadernos, livros;

- (No caso de Camile): o caderno da universidade e a caderneta utilizada no movimento social do qual participava;

○ Participações em redes sociais. 


\section{O Sistema Conversacional (inerente à pesquisa na Epistemologia Qualitativa)}

Considerando o processo relacional que caracteriza esse tipo de pesquisa, assumimos a conversação, não como um instrumento específico, mas sob uma perspectiva mais ampla, como o sistema conversacional que se desenvolve com o amadurecimento da relação pesquisadorparticipante. Nesse sentido, ao longo de toda a pesquisa, estivemos atentos aos momentos de diálogos informais como importantes oportunidades para o desenvolvimento de um clima natural e espontâneo na relação pesquisador-participante, propício à pesquisa porque facilitador da expressão subjetiva. Ressaltamos, em nosso processo de construção teórica, a quantidade e a relevância das informações oportunizadas nesses momentos informais.

A tabela a seguir oferece uma sistematização dos instrumentos de pesquisa com relação aos objetivos geral e específicos do estudo e ao cronograma programático do estudo. Por tudo que até o momento foi explicitado em relação ao arcabouço teórico-epistemológico adotado, tal sistematização se constitui apenas em um esforço didático explicativo sobre o conjunto de instrumentos que foram caracterizando os momentos da pesquisa. No processo real da pesquisa, instrumentos e objetivos sobrepuseram-se de forma não tão definida e ordenada. Na prática, os momentos de interação do pesquisador com os sujeitos de pesquisa constituíram fontes de informações para reflexões do pesquisador relacionadas a quaisquer um dos objetivos da pesquisa. 


\begin{tabular}{|c|c|c|c|}
\hline Objetivos Específicos da Pesquisa & Instrumentos & Apêndices & Período de realização \\
\hline \multirow[t]{4}{*}{$\begin{array}{l}\text { - Selecionar alunos com expressões de } \\
\text { elementos de criatividade na } \\
\text { aprendizagem em contexto formal ou } \\
\text { não-formal }\end{array}$} & $\begin{array}{l}\text { 1. Observação dos participantes no } \\
\text { decorrer do curso de capacitação }\end{array}$ & & $\begin{array}{l}\text { 24/05/2013: Encontro de Sistematização dos Módulos } \\
\text { anteriores do Curso } \\
\text { 03/06/2013: Encontro sobre Ferramentas de Diálogo/DRP } \\
\text { 05/06/2013: Encontro sobre Ferramentas de Diálogo/DRP } \\
\text { 07/06/2013: Encontro sobre Ferramentas de Diálogo/DRP } \\
\text { 10/06/2013: Encontro sobre Ferramentas de Diálogo/DRP } \\
\text { 13/06/2013: Encontro sobre Ferramentas de Diálogo/DRP }\end{array}$ \\
\hline & $\begin{array}{l}\text { 2. Entrevista semi-estruturada de } \\
\text { apresentação do projeto com } \\
\text { monitores da Ação Educativa Não- } \\
\text { formal }\end{array}$ & APÊNDICE A & $\begin{array}{l}\text { 03/06/2013: Encontro com Regina } \\
\text { 11/06/2013: Encontro com Isabela e Fernando }\end{array}$ \\
\hline & $\begin{array}{l}\text { 3. Observação dos participantes durante } \\
\text { a aplicação das "Técnicas de } \\
\text { Diagnóstico Rápido Participativo - } \\
\text { DRP" }\end{array}$ & & $\begin{array}{l}\text { 17/06/2013: Encontro Aplicação do DRP - Escola } 1 \\
\text { 18/06/2013: Encontro Aplicação do DRP - Escola } 1 \\
\text { 20/06/2013: Encontro Aplicação do DRP - Escola } 2 \\
\text { 20/06/2013: Encontro Aplicação do DRP - Escola } 3 \\
\text { 21/06/2013: Encontro Aplicação do DRP - Escola } 3\end{array}$ \\
\hline & $\begin{array}{l}\text { 4. Observação dos participantes nos } \\
\text { encontros: } \\
\text { - de preparação para o Fórum; } \\
\text { - do Fórum Científico; } \\
\text { - de avaliação do Curso de } \\
\text { Capacitação; } \\
\text { - de avaliação do Projeto por uma } \\
\text { equipe externa. }\end{array}$ & & $\begin{array}{l}\text { Junho Agosto / } 2013 \\
\text { 02/08/2013: Encontro Planejamento e Análise dos Dados } \\
\text { 05/08/2013: Encontro Escola } 1 \\
\text { 05/08/2013: Encontro Escola } 1 \\
\text { 06/08/2013: Encontro Escola } 2 \\
\text { 12/08/2013: Preparação Fórum Científico } \\
\text { 13/08/2013: Preparação Fórum Científico } \\
\text { 14/08/2013: Preparação Fórum Científico } \\
\text { 20/08/2013: Ensaio Geral } \\
\text { 22/08/2013: Forum Científico Final } \\
\text { 23/08/2013: Forum Científico Final } \\
\text {--/08/2013: Avaliação Curso de Capacitação } \\
\text {--/08/2013: Avaliação do Projeto }\end{array}$ \\
\hline \multirow{3}{*}{$\begin{array}{l}\text { - Caracterizar a configuração subjetiva } \\
\text { da ação do aprender da participante } \\
\text { no contexto não-formal }\end{array}$} & 5. Entrevista semi-estruturada I & APÊNDICE B & Setembro/2013 \\
\hline & 6. Entrevista semi-estruturada II & APÊNDICE C & Setembro/2013 \\
\hline & 7. Completamento de Frases & APÊNDICE D & Setembro/2013 \\
\hline
\end{tabular}


- Analisar formas de expressão da aprendizagem criativa no contexto

não-formal em suas inter-relações com a configuração subjetiva da ação

do aprender produzida neste

contexto.
8. Observações realizadas na etapa de seleção

9. Entrevista semi-estruturada III

Entrevista semi-estruturada IV (com
auxílio de fotos)

11. Diário reflexivo de aprendizagem e

Porfólio do Projeto

12. Redação

13. Observações nas escolas

14. Análise do caderno/material do aluno
APÊNDICE G

APÊNDICE H

Outubro/2013

Dezembro / 2013

Setembro Dezembro/2013

APÊNDICE I

Novembro / 2013

Setembro/2013

Setembro Dezembro/2013

Quadro 2: Sistematização dos instrumentos de pesquisa 


\subsection{O Processo Construtivo-Interpretativo do Modelo Teórico}

Na epistemologia qualitativa, o modelo teórico se conforma no conjunto de categorias e construções teóricas, respectivamente, utilizadas e elaboradas pelo pesquisador em um processo que permite a abertura de novas zonas de sentido sobre o problema estudado. O modelo teórico inicia-se, portanto, nas primeiras representações do pesquisador sobre o problema de pesquisa e reflete seu caminho de reflexões e construções teóricas no decorrer da pesquisa. Neste entendimento, o modelo teórico não existe fora do processo mesmo de construção da pesquisa. Processo, este, que se desenvolve na lógica configuracional que permeia todas as subjetividades envolvidas, incluindo a do próprio pesquisador integralmente implicado como sujeito criativo de seu processo construtivo interpretativo (GONZÁLEZ REY, 1999b, 2005b, 2005c).

A figura, abaixo, busca esclarecer nosso processo de ideias, reflexões e construções teóricas que resultam, em seu conjunto, no modelo teórico elaborado no caminho da pesquisa.

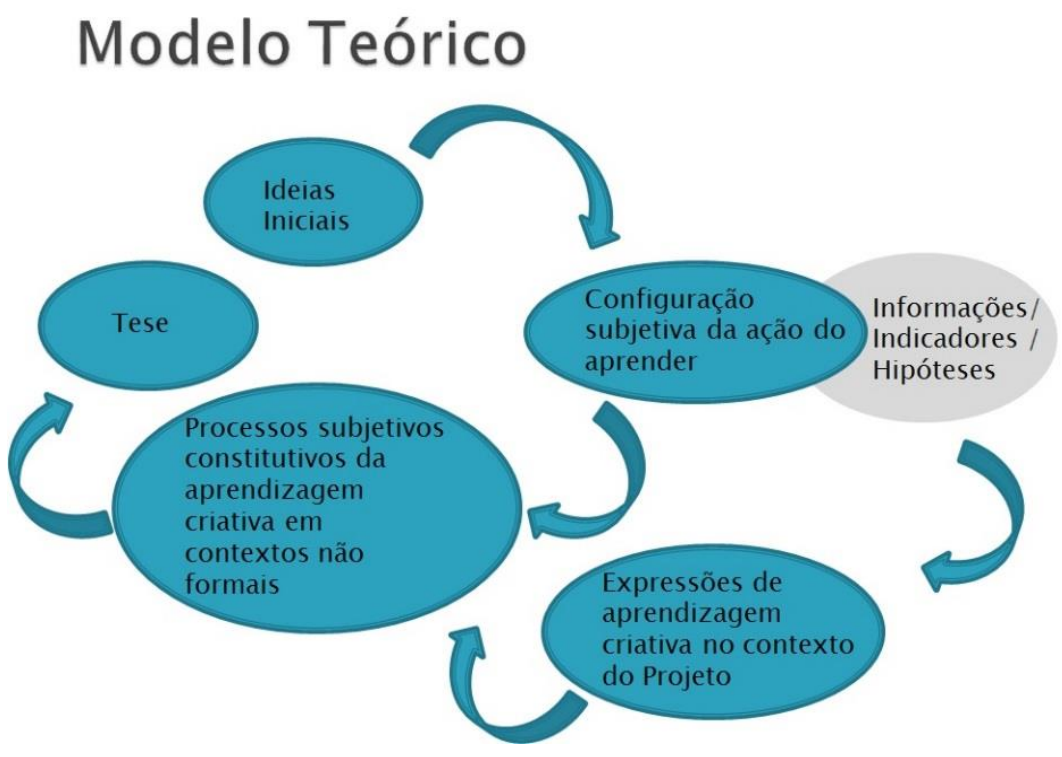

Nesta representação, iniciamos nosso processo nas primeiras ideias iniciais sobre o tema da pesquisa para, com base no amplo tecido de informações construídas a partir da realização dos instrumentos de pesquisa, elaborar indicadores e hipóteses sobre a configuração subjetiva da ação do aprender das participantes do Projeto. Em seguida, 
analisamos expressões da aprendizagem criativa das participantes no contex to do Projeto, em suas inter-relações constitutivas com as respectivas configurações subjetiva da ação do aprender. Logo a seguir, com base em uma análise integrada dos casos, tecemos considerações sobre processos subjetivos constitutivos da aprendizagem criativa em contextos não-formais; análise esta que nos permite a construção de nossa tese de pesquisa. 


\section{CAPÍTULO IV: ANÁLISES DAS INFORMAÇÕES E CONSTRUÇÕES TEÓRICAS}

Nesta parte do trabalho, objetivamos compreender a emergência da criatividade na aprendizagem em diferentes momentos das experiências das participantes da pesquisa na ação educativa não-formal. Para tanto, em cada estudo de caso, analisaremos a caracterização da participante e a caracterização da configuração subjetiva da ação de aprender no contexto não-formal, realçando a expressão de elementos subjetivos da subjetividade social do Projeto e os principais núcleos de sentidos subjetivos vinculados ao aprender nesse contexto. A seguir, analisaremos características da aprendizagem da participante no contexto não-formal, focando momentos de emergência da aprendizagem criativa, como sendo aquela em que o sujeito se orienta ativamente para, além da compreensão e da personalização da informação, à problematização, à transcendência e à elaboração de novas ideias (MITJÁNS MARTÍNEZ, 2012).

Realizaremos nossas análises com base nessas características distintivas da aprendizagem criativa, confirmando, ou não, suas ocorrências no contexto não-formal. Analisaremos ainda a expressão, ou não, de outros processos subjetivos constitutivos apontados pelos estudos da área (a saber, a expressão da condição do sujeito, a produção subjetiva que recursivamente alimenta para novas aprendizagens, a aprendizagem como configuração subjetiva, e os processos operacionais subjetivados). Consideraremos, por fim, um processo subjetivo constitutivo, que acreditamos pertinente ao contexto nãoformal estudado e que se constitui como elemento novo ao campo teórico da aprendizagem criativa: a personalização da experiência de aprendizagem. No decorrer das análises, buscaremos pontuar as inter-relações entre esses processos subjetivos e as respectivas configurações subjetivas da ação do aprender.

Antes de começarmos, no entanto, cabe esclarecer que os nomes de cada participante são fictícios; e que as transcrições das falas são acompanhadas de informações, marcadas entre colchetes e em itálico, que a autora julga relevantes tais como descrição de comportamentos não verbais, ênfases no tom da voz, complementação de informações implícitas, entre outras. Ressaltamos ainda que, de forma a salvaguardar a privacidade de todos os envolvidos na pesquisa, o nome da instituição realizadora do Projeto será denominado doravante de Instituição F. e o nome da cidade dos participantes será denominado $\mathrm{S}$. 


\subsection{A participante Camile}

\subsubsection{A caracterização de Camile}

Com base em nossas interações, percebemos em Camile uma pessoa perspicaz, sociável, atenta e interessada. Camile nos impressiona pela inteligência e pela articulação de sua fala que, pela fluência e simplicidade, sempre nos sugeriram uma postura de autoconfiança, reflexiva e madura.

A família de Camile é de classe econômica média baixa. Sendo seus pais separados, Camile mora com o pai, porém é bastante unida à mãe que reside perto de sua casa. Expressa que a companhia e a formação moral são os dois maiores valores de sua relação com a família; e com frequência posta fotos da família e de amigos em suas redes sociais. Camile é mulata, sendo sua mãe branca e seu pai negro. Tem como hobby ouvir músicas e cantar. Com efeito, com frequência posta trechos de músicas de vários estilos em sua rede social que, juntamente, com temas sobre crítica social e política, são os assuntos predominantes em seu eixo de interesse.

No início da pesquisa, Camile estudava o terceiro ano do ensino médio em uma escola pública no DF. Antes de completá-lo, em agosto de 2013, passou antecipadamente no vestibular e ingressou no curso de graduação em Serviço Social de uma universidade pública federal. Vale ressaltar que, no Brasil, o ingresso em universidades federais é difícil e bastante concorrido por alunos de todas as classes sociais, inclusive as mais abastadas e com maiores condições de custear boas escolas preparatórias particulares. Pela condição socioeconômica da família, Camile sempre estudou em escolas públicas no ensino básico, que são em geral reconhecidas como de nível inferior a escolas particulares. Enfatizamos, assim, o valor real e simbólico de seu ingresso na universidade, em especial, por conseguilo antes do término do ensino médio.

A participação de Camile no Projeto aconteceu precisamente em seu último ano do ensino médio. No entanto, por haver ingressado na universidade no segundo semestre do ano, nossas observações e interações de pesquisa no contexto formal escolar aconteceram em seu último semestre na escola e em seu primeiro semestre na universidade. Na escola, entrevistamos os professores de Filosofia e Sociologia e, na universidade, realizamos observações na disciplina de Introdução ao Serviço Social e 
conversas com a professora. Tais disciplinas foram todas identificadas por Camile como as mais alinhadas às temáticas do Projeto.

Camile tem um histórico de rendimento acadêmico excelente e, ao mesmo tempo, um conjunto de experiências em movimentos estudantis e sociais. Durante o ensino médio, foi sucessivamente eleita pelos estudantes como líder do grêmio estudantil, sendo a única em sua escola a se candidatar para o cargo. Em seu último ano, era também membro do conselho escolar e presidente de sua turma. Camile é ainda participante ativa do Fórum da Juventude de S., movimento social de sua cidade.

Segundo Camile, a opção pelo curso de Serviço Social na universidade foi deliberadamente tomada por se aproximar dessa sua trajetória de atuação política e social. Atuação que desenvolve, não apenas em suas redes sociais, conforme apontado, mas também nos espaços da escola e da cidade.

\subsubsection{A configuração subjetiva da ação de aprender em Camile no contexto não-formal}

Com o objetivo de compreender a configuração subjetiva da ação do aprender em Camile, no contexto do Projeto, nosso esforço construtivo-interpretativo centrou-se na elaboração de hipóteses sobre elementos subjetivos constituintes desta configuração, entre eles: (1) elementos de sentidos subjetivos relacionados à expressão da subjetividade social do contexto do Projeto na subjetividade individual de Camile; e (2) núcleos de sentidos subjetivos organizados na trajetória de vida e no momento atual de Camile. Aprofundaremos nossa análise sobre cada um deles nas seções a seguir.

\subsubsection{Elementos de sentidos subjetivos relacionados à subjetividade social do contexto não-formal}

Conforme já citado no capítulo anterior, a realização do Projeto teve a duração de aproximadamente um ano, com diversos encontros e visitas a instituições que se alinhavam aos módulos do curso. Neste período, diferentes equipes foram responsáveis pela condução de cada módulo e pela realização de palestras específicas. Pode-se assumir, no entanto, que os dois monitores, responsáveis pela condução geral da ação educativa, e os nove bolsistas-participantes consistiram o grupo principal do contexto do Projeto. 
As análises das informações de pesquisa nos permitiram a construção de alguns elementos da subjetividade social do grupo que se configuram relevantes na constituição dos processos de aprendizagem de Camile no contexto do Projeto. Tais elementos de sentidos subjetivos compartilhados pelo grupo se expressavam: (1) na consideração pelo Projeto como oportunidade privilegiada; e (2) na relação com o clima relacional e comunicacional de abertura e confiança do grupo. Não consiste nosso objetivo esgotar a expressão de elementos da subjetividade social do Projeto na subjetividade individual de Camile. (Nem poderíamos!) Assumimos esses dois por suas relevâncias em nossas construções interpretativas.

\section{(1) a consideração pelo Projeto como oportunidade privilegiada;}

Consideramos que este elemento da subjetividade social do grupo relaciona-se a sentidos subjetivos diversos associados à relação dos participantes com a infraestrutura física da instituição realizadora do Projeto, à origem socioeconômica dos participantes, ao processo de seleção, ao recebimento da bolsa de pesquisa, ao momento de vida do final do ensino médio, entre outros. Comentamo-los a seguir.

As instalações da instituição realizadora do Projeto ficavam em um complexo de prédios novos, com uma arquitetura moderna e sofisticada, de vidros verdes e paredes e estruturas metálicas brancas. Toda a infraestrutura física, exterior e interior, eram de altíssima qualidade, desde chão e paredes, até móveis e equipamentos nas salas. Ao mesmo tempo, todos os nove participantes do Projeto residiam em áreas do entorno da capital, e provinham de realidades socioeconômicas entre classe média baixa e classe baixa, real e simbolicamente diferenciadas da realidade do centro da capital em si. Interpretamos que a vinda à capital, para os encontros do Projeto, associada ao grande contraste da infraestrutura da instituição com a infraestrutura das escolas públicas e demais instituições públicas do entorno consistiram uma fonte de sentidos subjetivos diversos e contraditórios relacionados tanto a um distanciamento identitário quanto a um sentimento de autovaloração.

Em seu um relato na entrevista semiestruturada IV (APÊNDICE F), sobre a retrospectiva do Projeto, Camile coloca:

No início a gente não sabia nada. Chegou todo mundo tímido...A gente vinha aqui...Mas a gente não sabia muito bem o que eles [a equipe 
organizadora] queriam, o quê que a gente tinha que fazer. [...] Agora todo mundo fala.

Esta entrevista foi realizada no pátio interno da instituição, em meio ao jardim e aos prédios do complexo. Em nossas interpretações, consideramos que a expressão "a gente vinha aqui" nos constitui base para um indicador da relação particular com o espaço físico, como um espaço diferente e distante. Consideramos ainda que o decorrer do projeto consistiu um processo de familiarização com o espaço em que sentimentos de insegurança e incertezas davam lugar a sentimentos de autovaloração.

Em um encontro de avaliação do curso, com a equipe de monitores, apontamos o seguinte diálogo:

Monitora: Então, vamo lá, desde o início. [...] No início, a previsão era para os encontros serem nas escolas...a gente achou que ia ser melhor assim. Mas aí, a gente teve dificuldades e acabou sendo aqui na [instituição organizadora] mesmo...

Participante: É mas foi legal!!..Vir pra cá. Conhecer aqui... um lugar diferente...Pegar a van! [Todos os participantes acenam concordando.]

Ainda em outro encontro de avaliação geral do Projeto, realizado por equipe externa, outra informação nos permite a interpretação de uma relação diferenciada com o espaço físico da instituição:

Monitora: No início, ...vocês sabiam do curso?

Participante 1: A gente não sabia nada. A gente achava que era na escola todos os dias.

Monitora: E com isso vocês ficavam mais animados ou menos?

Participante1: Mais. Vir para a [instituição] era mais legal do que ficar na escola.

Compreendemos, nos trechos acima, que na avaliação final do curso pelos participantes, após terem se familiarizado com o ambiente e se apropriado dos espaços do complexo da instituição, o mesmo distanciamento existe, porém, já marcado por sentimentos de carinho e de saudade.

Neste mesmo encontro, os participantes realizaram uma dinâmica de grupo onde foram convidados a listar diversos aspectos do Projeto e, em seguida, a colocar no chão, a partir de um ponto central, papéis de diferentes tamanhos com os elementos listados. $\mathrm{O}$ valor real e simbólico dos elementos era expressado por meio do tamanho do papel e de sua posição em relação ao ponto central. Nesta dinâmica, o aspeco "Infraestrutura da 
Instituição F." foi avaliado, pelo consenso do grupo, com um papel grande e bem próximo do centro; fato que nos consiste ainda outro indicador do valor do espaço físico como elemento da subjetividade social do Projeto.

Pelos indicadores construídos, interpretamos que essa relação com o espaço físico foi marcada por sentidos subjetivos diversos que contribuíram tanto para a coesão do grupo quanto para a consideração pelo Projeto como uma oportunidade diferente e privilegiada de aprendizagem, favorecendo nos participantes sentimentos de autovaloração.

Em nossas construções interpretativas sobre esse elemento da subjetividade social do grupo, apontamos ainda o valor que Camile conferia a adquirir uma bolsa de estudos na Instituição $F$. Na entrevista semiestruturada IV (APÊNDICE F), ao responder à pergunta sobre o que significava para ela a participação no Projeto, Camile responde que se sentiu "beneficiada". "Me senti muito importante". Notamos aqui que, frente a uma pergunta que poderia se desdobrar em expressões de satisfação pessoal, desafio pessoal, ou expectativas de novos aprendizados e oportunidades, Camile privilegia uma comparação com seu contexto social. Nesta linha de raciocínio, interpretamos em Camile a produção de sentidos subjetivos relacionados a sua origem socioeconômica, ao processo de seleção dos bolsistas, à diferenciação do tipo de oportunidade de trabalho tradicionalmente ofertado à família e a conhecidos, o que nos consistem indicadores da consideração pelo Projeto como uma oportunidade privilegiada como fonte de sentidos subjetivos em Camile.

Chamou-nos atenção ainda sua menção a "Ser bolsista da Instituição $F$ " em uma redação de seu caderno escolar sobre seu curriculum vitae, e essa mesma menção em seu perfil em sua rede social. Ao se autorreferenciar como "bolsista da Instituição F", interpretamos ainda sentidos subjetivos relacionados ao momento de vida do final do ensino médio, marcado por expectativas profissionais sob as quais o Projeto adquire um forte valor simbólico. Esta informação nos constitui ainda outro indicador para a mesma construção teórica da expressão deste elemento da subjetividade social do grupo na subjetividade individual de Camile. 
(2) a relação com o clima relacional e comunicacional de abertura e confiança do grupo;

Em nossas construções, este elemento da subjetividade social do grupo relacionase a sentidos subjetivos associados, em primeiro, à própria representação do grupo como uma equipe coesa de alunos selecionados para uma importante missão; em segundo, à relação de empatia que se estabeleceu entre os monitores do Projeto e os participantes; e em terceiro, à dinâmica do trabalho pedagógico orientado para a expressão dos participantes e construção conjunta da experiência pedagógica.

Em nossas interpretações, vários aspectos da experiência do Projeto, compartilhados pelos nove participantes, contribuíram para desenvolver um sentimento de coesão do grupo. Entre eles, a mesma origem socioeconômica, o sucesso no processo de seleção das bolsas do Projeto, o estranhamento inicial com o ambiente da instituição, o desconhecimento inicial sobre o Projeto, o enorme desafio das atividades de aplicação do DRP nas respectivas escolas e de apresentação no Forum final. Com efeito, em nossas observações nos encontros, percebemos que a grande maioria das dúvidas, sobre o andamento do Projeto e sobre a realização das atividades, era sempre expressa por cada um do grupo, de forma a incluir o grupo inteiro: "Nós podemos fazer assim"?, "Nós pensamos que" ...; “a gente queria...". No decorrer do Projeto, desenvolveu-se uma percepção identitária do grupo como sendo "os estudantes bolsistas da Instituição $F$ do Projeto"; forma pela qual eles eram reconhecidos e, ao mesmo tempo, se autodenominavam. Interpretamos, neste conjunto de informações, um indicador de que sentidos subjetivos, relacionados a este sentimento de coesão do grupo, favoreceram o desenvolvimento de vínculos de amizade e de união entre os participantes, promovendo significativamente relações de apoio mútuo, de comprometimento e de um clima de abertura ao diálogo e à comunicação do grupo.

Ressaltamos ainda relação de empatia que se estabeleceu com os monitores do Projeto, marcada pela identificação mútua e pela admiração dos participantes por estes, como aspecto marcante da experiência do Projeto. O próprio perfil dos monitores nos permitiu essa interpretação. Os dois eram jovens entre os 25 e 30 anos, provenientes também de áreas do entorno da capital federal, e com familiaridade com elementos da cultura jovem dessas localidades; entre eles, a cultura hip hop, a cultura de mídias digitais, a MPB, o samba e a música sertaneja. Destacamos ainda o vocabulário utilizado pelos 
monitores, carregado de expressões da cultura jovem do DF, tais como "Boto fé!", "Beleza", "Tô de boa", "Véi!"

Um dos monitores sabia dançar hip hop, improvisar rimas, desafiar para batalhas, e mixar batidas com as mãos e a boca. Com frequência, o grupo se juntava nos intervalos e nos momentos antes e depois dos encontros para cantar e dançar.

Consideramos que a relação que se estabeleceu entre os participantes e os monitores era caracterizada pela surpresa dos participantes em conhecer pessoas que "são como eles" e que, ao mesmo tempo, discutem questões "sérias" de saúde pública, democracia, drogas, escola, ciência, entre outras, em uma instituição tão "importante" como a Instituição F. Não por acaso, no encontro coletivo de avaliação do Projeto por avaliadores externos, ao selecionar o tamanho do papel e a posição em relação ao centro, entre os dezesseis aspectos elencados, os monitores, chamados por todos de "Manos da Instituição $F$.", foram unanimemente posicionados com o papel grande, exatamente no centro. Interpretamos, neste conjunto de informações, um indicador de que sentidos subjetivos relacionados a estes aspectos de identificação e admiração eram compartilhados pelos participantes e contribuíam para favorecer o clima de abertura ao diálogo e à comunicação do grupo.

Por fim, apontamos o próprio fazer pedagógico dos monitores, orientado para a expressão dos participantes e para a construção conjunta da experiência pedagógica, como aspecto marcante do Projeto para a construção do clima relacional e comunicacional como elementos da subjetividade social do grupo. Ambos com curso superior e prática pedagógica tanto em sala como em projetos sociais, os monitores eram altamente comprometidos com a ação educativa e com os participantes, desenvolvendo um trabalho que, na prática, era marcado pela forte construção, conjunta com os participantes, de vários aspectos do Projeto, desde decisões sobre seu andamento até as discussões sobre temáticas do programa.

Apontamos o diálogo abaixo como exemplo ilustrativo deste fazer pedagógico. Nele, a decisão sobre as duas dinâmicas de DRP, a serem aplicadas nas escolas, é comumente negociada e acordada por todos.

Participante 1: Podia ser o Mapa Falado e o Diagrama de Venn.

Monitor 1: Eu tava conversando com o Monitor 2...o que a gente quer? A gente quer conhecer as percepções de saúde dessa comunidade. 
Então, a gente tava pensando em utilizar a Oficina de Imagens e o Mapa Falado. Porque o Mapa Falado traz os recursos que existem naquela comunidade e a Oficina de Imagens para levantar o que as pessoas pensam sobre saúde.

Monitor 2: O que vocês acham? ...A gente só pensou...

Participante 1: Acho que o Diagrama de Venn é importante para saber quem tem mais influência ali...Aí, se a gente tiver que falar com alguém a gente já sabe com quem que a gente vai lá falar.

Monitor 1: O Diagrama de Venn é muito legal para levantar as forças...É uma coisa mais interna, ligada às relações entre as pessoas mas a gente tá querendo levantar questões de saúde na escola...

Monitor 2: E [para o Diagrama de Venn] precisávamos fazer uma preparação muito antes. Dos atores que compõem aquele comunidade...

Monitor 1: Mas isso não impede vocês mais tarde de realizarem o Diagrama de Venn nos outros momentos...Entendeu?

Participante 2: Acho o Diagrama de Fluxo legal para saber como as coisas acontecem.

Monitor 2: $\quad$ Poderemos usar o Diagrama de Fluxo atrelado à Oficina de Imagens.

Participante 3: O Mapa Falado faz mais sentido que a Oficina de Imagens. A Oficina de Imagens não deixa de ser complexo. O pessoal não sabe nada e já vai ter que sair falando.

Participante 4: Mas depende de como a gente vai apresentando [...]

Participante 5: É. Quando a gente fez [entre o grupo], a gente entendeu.

Participante 3: Eu não entendi bem os objetivos [...] Não entendi o porquê ficar falando sobre aquelas imagens.

[...]

Participante 2: Acho que seria melhor primeiro o Mapa Falado e depois a Oficina de Imagens.

Participante 1: Eu também.

Participante 3: Eu também.

Participante 2: Todas as oficinas que a gente fez teve uma dinâmica primeiro, para deixar mais aconchegante. Seria uma boa fazer uma dinâmica na nossa. [...]

[Todos concordam.]

No diálogo acima, os monitores propõem as dinâmicas, argumentando seus motivos e, ao mesmo tempo, abrindo para discussão geral, negociando e incorporando novas sugestões sobre quais ferramentas de DRP aplicar. Enfatizamos o fato de tal decisão ser colocada em negociação com os participantes. Esta era uma estratégia utilizada a todo momento, em cada um dos módulos do curso, onde o próprio programa era sempre colocado em questão. Enfatizamos ainda, o quanto o diálogo acima se constitui como um rico momento de expressão de aprendizados dos participantes, sobre as próprias ferramentas de DRP.

Outra característica do trabalho pedagógico dos monitores expressava-se no uso de dinâmicas lúdicas e momentos de descontração, seja como fonte de reflexão sobre o conteúdo, seja como um convite à livre expressão dos participantes. A continuação do 
diálogo descrito acima, ocorrido no penúltimo encontro antes da aplicação do DRP é ilustrativa.

Participante 3: Eu não entendi bem os objetivos [...] Não entendi porquê ficar falando sobre aquelas imagens.

Monitor 2: Mas a gente vai introduzir a dinâmica a gente vai explicar. As pessoas vão ter uma noção e construir junto.

Participante 3: É porque o povo é muito crítico na minha escola. Eles não vão entender. [...]

Monitor 2: Pode ter certeza que vocês só vão fazer quando tiver tudo planejado e vocês souberem direitinho o que vão fazer. A gente não vai fazer a não ser que vocês estejam bem familiarizados. Pode ficar tranquilo, galera!

[...] Não vai chegar lá e fazer freestyle, não! A gente só vai fazer quanto a gente tiver certeza.

Participante 2: Vai ficar uma só pessoa para conduzir? Não seria legal que uma hora fosse uma e outra hora outra? ...trocar assim...

Participante 3: Vamos sofrer discriminação por sermos alunos da escola e fazer um trabalho com outros alunos.

Camile: Por isso era bom um crachá...

Monitor 1: Não se preocupem que vocês não vão chegar lá e ter que falar sobre o que é saúde e coisa e tal. O único que vocês precisam se apropriar é das ferramentas e conduzir...

Participante 1: Acho que a galera tem a ideia de que saúde é hospital, é médico. Tem que trazer alguma coisa para aumentar [ampliar] o conceito, dar uma outra visão.

Monitor 1: Mas é isso o que a gente quer. A gente quer saber o que aquelas pessoas pensam.

Participante 1: Não tem que ensinar nada, né? Agora entendi.

Monitor 2: É vocês estão ali só para mediar...mapear o território, levantar os recursos. Essa coisa da gente quando trabalha com pesquisa é uma coisa que a gente tem que ter muito cuidado... pra não influenciar... pra não trazer alguma coisa que a gente acha que a gente sabe...

[A monitora sugere, então, uma dinâmica de grupo para trabalhar a capacidade de escuta. Na dinâmica, uma pessoa inicia uma contagem de números e aguarda que um próximo espontaneamente se apresente para continuar. Todos têm que se olhar bem, interpretar movimentos e prestar atenção em quem está prestes a se apresentar. Todos riem muito e, no final, uma das participantes sugere outra dinâmica. Nesta segunda dinâmica, todos precisam colocar um objeto no interior da roda e cada um precisa contribuir com a narrativa de uma história associando sua contribuição a um dos objetos colocado no centro. Entre os objetos apresentados, estavam um anticoncepcional, uma camisinha, um absorvente, uma jarra d'água, um globo. A história surreal se desenrola a partir de uma menina com Síndrome de Down (Monitor 2) que é agredida e que consegue revidar a agressão esfaqueando o opressor (Participante 6), [...] o namorado da menina então pega a jarra e bebe o sangue do opressor (Monitor 1), todo sujo de sangue a menina salva o namorado, limpando-o com um absorvente (Estela) [...] A história termina com a menina especial grávida e feliz (Camile) Após essa segunda dinâmica, todos riem muito, surpresos e felizes com a história] 
[Volta-se, logo em seguida, ao assunto do DRP como se nada o tivesse interrompido]

Monitor 1: Vocês tão seguros pra falar do projeto?

Participante 1: Mais ou menos. Vou começar a gaguejar.

Monitor 1: Ah, mas isso é normal, véi.

Participante 1: É normal mas é feio.

Monitor 2: Mas todo mundo fica inseguro...eu também fico na hora de falar na frente do povo $[\ldots]$

Em nossas análises, este momento é ilustrativo de como o trabalho pedagógico dos monitores era permanentemente orientado à expressão do grupo. Como forma de amenizar a grande tensão gerada pela expectativa da aplicação do DRP, os monitores destinavam longo tempo a dinâmicas lúdicas e conversas livres que eram, ao mesmo tempo, um exercício de autoexpressão dos participantes. No trecho acima, chama-nos especial atenção que a segunda dinâmica proposta, tenha sido sugerida por Estela, uma das mais tímidas do grupo. Ressaltamos ainda as temáticas altamente sensíveis e polêmicas que surgiram na história, tais como sexo e o uso de anticoncepcional, gravidez na adolescência, violência sexual, assassinato, o amor adolescente, entre outros. Todas surgiram espontaneamente e dificilmente seriam abordadas com tamanha liberdade e fluidez na escola.

No último encontro antes da aplicação do DRP, havia um forte clima de apreensão, todos estavam tensos e ansiosos para o dia da ida à escola. Nesse encontro, chamou-nos atenção um diálogo marcado pela seguinte sequência, aparentemente desconexa:

$1^{\circ}$. Dúvidas sobre a mediação e a relatoria;

$2^{\circ}$. Amenidades sobre os programas de cada um no dia dos namorados;

$3^{\circ}$. Amenidades sobre o filme Faroeste Caboclo e o sexo nos filmes brasileiros ("Eles parecem cachorros! Ninguém fala nada e já começa a transar!" [Todos riem.];

$4^{\circ}$. Expressões de insegurança com a aplicação do DRP e falas de encorajamento dos monitores.

Ressaltamos, nesta sequência de diálogo, que cada participante sentia-se livre para trazer novos tópicos de discussão; as conversas iam e vinham em uma fluidez de comunicação que, aos olhos de uma pessoa mais afeita à rígida dinâmica da sala de aula, pareceria sem lógica e improdutiva. Observamos esse tipo de utilização do tempo na grande maioria dos encontros.

Não por acaso, no encontro coletivo de avaliação do Projeto por avaliadores externos, apontamos ainda o seguinte diálogo:

Avaliadora: Como vocês avaliam a participação de vocês no projeto? 
Participante: Talvez as pessoas sentiram uma certa liberdade de falar o que realmente queriam.

Na entrevista semiestruturada IV (APÊNDICE F), ao comentar sobre as grandes diferenças entre aprender no Projeto e aprender na escola, Camile relata:

Ah, ...a diferença foi a participação [com intensa entonação no início da palavra, denotando a impossibilidade de qualquer dúvida]. Na escola eu sempre participei muito, mas não era todo mundo que participava ao mesmo tempo do jeito que a gente participava aqui. Era meio que uma roda de bate-papo, não tinha meio que "Ah! ...Eu sou o professor e vocês são os alunos vocês tem que me escutar...!" Aqui a gente era uma troca de ideias constante.

Em nossas observações, as tardes dos encontros consistiam longas conversas, em geral sobre temáticas polêmicas e familiares à realidade dos jovens, marcadas pela forte troca de impressões e opiniões de cada um dos participantes, entremeadas por brincadeiras e pela sensação conjunta de todo o grupo ser co-responsável por reflexões "sérias", pela construção de ideias sobre a realidade da escola e da cidade, e pela própria implantação do projeto.

Em nossas análises, consideramos que o conjunto de informações relacionadas ao fazer pedagógico dos monitores nos permite a construção interpretativa de que este fazer pedagógico contribuía para a confiança e autonomia dos participantes, consistindo um indicador para a construção do clima relacional e comunicacional de abertura e de confiança como elemento da subjetividade social do grupo. Pontuamos ainda que a informalidade e a fluidez das conversas contribuíam para a confiança e autonomia de expressão dos participantes não comumente experimentadas, sob essas bases, no ambiente escolar.

Por fim, consideramos que, em Camile, a expressão deste elemento da subjetividade social do clima relacional e comunicacional do grupo articula-se ao valor que ela conferia a suas experiências como líder do grêmio estudantil e membro do movimento social, e a sua capacidade de oratória e de mobilização de grupos, favorecendo, no contexto não-formal, sentimentos de autovaloração, de confiança e autonomia. Aprofundaremos essa análise na seção a seguir. 


\subsubsection{Núcleos de sentidos subjetivos organizados a partir da trajetória de vida e na ação de Camile no contexto não- formal}

Em articulação com os elementos de sentidos subjetivos relacionados à subjetividade social do Projeto, integram-se à configuração subjetiva da ação do aprender em Camile no contexto não-formal, núcleos de sentidos subjetivos organizados tanto em sua trajetória de vida quanto no momento atual de vida de Camile. Entre eles, construímos núcleos de sentidos subjetivos que se expressavam: (1) na postura crítica e de confrontação; (2) na relação com a conturbada saída da escola de ensino médio; (3) no reconhecimento social de suas experiências de atuação no grêmio estudantil e no movimento social; e (4) na postura de flexibilidade e abertura para processos de aprendizagem. Analisamos, a seguir, cada um deles em particular.

(1) A postura crítica e de confrontação frente a situações e conteúdos de aprendizagem

Em diversos momentos nos encontros do Projeto, observamos Camile assumir uma postura crítica e de confrontação frente a situações e conteúdos de aprendizagem. Reproduzimos, abaixo, um diálogo ocorrido em um dos encontros em uma discussão sobre métodos avaliativos na escola:

David: Reprovei em Biologia e Química. É difícil. Só passa com a prova [pausa] ou na formativa. [dando a entender que há, no sistema avaliativo, um excesso de peso na prova e que não se importava com a avaliação formativa]

Monitora do curso: [...] Pois é a avaliação formativa é justamente para evitar isso. .......] Existem várias formas de avaliação [...] (após uma longa explanação, conclui que a avaliação formativa é essencialmente positiva para respeitar o processo singular de cada aluno, recebendo a confirmação de todos)

Camile: (Quando o assunto já estava concluído para todos) Sou totalmente contra o método de avaliação formativa porque você é bem avaliado se chega na aula e fica calado. [...] Perguntar demais é mal avaliado na avaliação formativa.

Neste exemplo, tão recorrente em outras participações de Camile no curso, ainda que o grupo já tivesse acordado uma posição, e a subjetividade social tendesse para a aceitação da fala da monitora, Camile traz uma posição contrária e audaciosa, demonstrando o exercício da condição de sujeito, tanto em sua reflexão crítica sobre a 
avaliação formativa, quanto em oposição à subjetividade social instalada. Em diversos momentos de participações de Camile no Projeto, observamos que, com frequência, ela iniciava sua fala dizendo "Como sou do contra..." e prosseguia apresentando argumentos na direção contrária a do senso comum em discussão. Compreendemos, nesses momentos, o prazer que Camile tinha em expressar suas opiniões, em se posicionar criticamente, em relacionar ideias e trazer perspectivas novas. Compreendemos ainda sua orientação primeira para a dúvida frente ao exposto e seu orgulho próprio por isto.

Consideramos que, no contexto escolar, essa postura crítica igualmente se expressava. Apontamos as intensas e difíceis experiências como líder do grêmio estudantil e representante dos alunos no Conselho escolar como um indicador para essa construção. A seguir, reproduzimos dois relatos de Camile sobre eventos vivenciados em sua escola na entrevista semiestruturada II (APÊNDICE C). No primeiro, Camile descreve o caso de sua transferência de turma como decisão unilateral da direção da escola. Embora nunca lhe houvessem explicado claramente o motivo da transferência, informações "não oficiais" a sugeriam que a razão foi "desfazer grupos". Segundo Camile:

Pesquisador: [Referindo-se à lembranças de bons professores...] Você lembra assim em que momentos; em que disciplinas esses professores te incentivavam? ...Algum mais específico?

Camile: [...] A última lembrança que eu tenho é do meu professor de Química, no dia em que eu fui transferida de turma, porque eu era do $3^{\circ} \mathrm{A}$ e eu fui para o $3^{\circ} \mathrm{D}$; e eu nunca imaginei que eu ia ser transferida de turma e eu lembro assim que quando ele foi falar que iam transferir três alunos da minha turma, ele disse que ia transferir pelo fato de alguns estarem sendo prejudicados e não estarem se desenvolvendo e eu nunca imaginei que ia ser eu e quando a diretora chegou lá na porta e me chamou eu fiquei [pausa e corte na respiração] ...Aí, chamou uns dez alunos, aí ela deu uma advertência pros outros e eu fui a primeira a ser chamada pra ser transferida de turma e eu fiquei chocada [com entonação de surpresa]...Aí, eu "Meu Deus, porquê??"...Aí, todo mundo chorou lá na sala. Foi uma coisa muito...

Pesquisador: Mas isso porquê? Porque vocês podiam ir pra outra turma para poder ser mais...[controlados?]

Camile: Olha, na realidade foi eu e mais dois amigos que fomos transferidos porque segundo esse professor, [...] a minha sala era muito dividida em grupinhos e me tirando... [...] eles disseram que eu tava sustentando a turma toda, eu que lembrava, eu que ajudava o pessoal e eles me tiraram de lá pra turma se virar sozinha e pra que eu me desenvolvesse melhor. Na turma que eu fui transferida, eu fui transferida exatamente para turma onde eu tenho uma amiga minha que, no $1^{\circ}$ Ano, a gente se juntava pra estudar...então, de certa forma, foi bom [...] E esse professor eu lembro também do meu último dia de aula que eu tive que ele [...] ele me chamou no canto pra falar "Camile, você vai pra Unb mas não entra em politicagem, fica muito dedicada pra você estudar 
e não é pra entrar em nada de política não...Mas ele falou de um gesto irônico, mas eu entendi o que ele quis dizer, que foi pra eu me...pra eu focar, né?

Pesquisador: [...] mas isso é uma coisa que você tem em você e é tão bom e tá faltando tanto...

Camile: ....e eu tô me controlando [...]

...mas ele falou ironicamente, mas eu entendi o que ele quis dizer. Mas esse professor foi bastante importante pra mim. Foi até eu que organizei a blusa dos formandos do $3^{\circ}$ Ano e na blusa a gente fez uma homenagem pra esse professor [...] ele tava sempre no meu pé, sempre me cutucando, uma prova que valia 2 , se eu tirasse 1,7 ele já me ficava no meu pé [...]

Assumimos que o histórico de atuação política e de mobilização estudantil de Camile incomodava diretamente a direção da escola e a colocava em uma difícil e desafiadora posição de mediadora dos interesses dos alunos que, não obstante, ela enfrentava e sustentava. No segundo relato, descrito na mesma entrevista, Camile aponta dois outros momentos de difícil diálogo com dois professores da escola.

Pesquisador: Como é a sua relação com os professores?

Camile: Eu sempre tive uma relação boa, uma relação de respeito. Só quando eu saí da escola eu senti uma coisa assim...um pouco tensa pelo fato de eu estar na liderança e às vezes levar a culpa de tudo. Por exemplo, os professores, eles eram muito legais e tudo o mais, mas em alguns momentos eles falhavam, e falhavam feio, e eu tinha esse papel de ser porta-voz entre alunos e direção e eu questionava mesmo e alguns professores se sentiam chateados comigo. Só que a minha relação sempre foi boa.

Pesquisador: É incrível como a escola é mal preparada pra ouvir crítica, né?

Camile: É muito, é muito mal preparada. Eu fico tão...tão de cara...porque assim...foi o fato de um professor aplicar a prova sem explicar a matéria...e era assim uma matéria muito difícil. E ele vinha destratando mesmo os alunos, chamando os alunos de burro, sendo ignorante, sendo muito irônico, ele era muito irônico e, assim, eu só fiz o que eu deveria fazer... e eu fiz mesmo...e eu não me arrependo de ter feito...Eu fiz um documento de duas páginas relatando tudo o que todo mundo tava falando pra eu relatar e ainda assinei meu nome bem grandão CAMILE S. do Grêmio, do Conselho Escolar, presidente de turma, ...coloquei tudo...e depois ele veio criticar a turma. Na verdade foi numa aula, ele pegou praticamente um horário todinho, só pra falar assim "Ah, eu acho que a pessoa que fez esse documento deveria ter digitado e mandado pra Regional logo direto porque já que eu sou um monstro, eu sou esse ogro todo [com um tom de ironia] e...ele não falou diretamente para mim só que ele tava usando um sarcasmo, usando aquela ironia toda e nem olhava pra mim, mas eu sabia que era pra mim e eu ficava só olhando assim....[cara de surpresa, de quem não acredita]...cara ?!?!...

Pesquisador: E você chegou a responder alguma coisa?

Camile: Eu não respondi porque eu já tava saindo da escola também e eu não queria deixar um clima mais tenso...Mas foi só esse professor. Só foi esse professor que eu tive esse embate, vamo dizer assim, mas com todos os outros...E a gente, tinha uma relação boa [referindo-se ao professor] Só que ele não soube aceitar a crítica, ele não soube entender que se um grupo de alunos se organizou para fazer isso é porque tinha um motivo...E ele não soube entender e o nosso relacionamento antes era muito bom. A gente conversava, 
...brincava, $[. .$.$] e ele tocava violão. Eu até brincava com ele "Ah, professor,$ que dia que o senhor vai trazer o violão pra gente cantar na escola". Mas tirando isso...

Pesquisador: É incrível a dificuldade de ouvir, né? Cada vez eu me convenço mais que isso é culpa da falta de canais de diálogo...Porque diálogo é prática, é exercício. As pessoas precisam saber falar e ouvir e as pessoas não sabem ouvir [...]

Camile: Não sabem. Não sabem mesmo. Também teve um outro caso que a professora de Sociologia [...] que foi num dia que um amigo meu foi divulgar o Fórum da Juventude de S.[ o movimento social do qual participa] lá na minha turma e eu tava junto, eu tava acompanhando. Aí, ele começou a falar, [...] e pediu três minutos pra professora. Então, quando ele começou a falar, ela interrompeu envolvendo Sociologia no que a gente tava falando, tipo nada a ver, viajou...Aí, quando ele foi voltar a falar, ela disse "Não. Se retire da minha sala porque você tá me incomodando!"... Ela falou assim pra ele! ...E eu...[pausa e corte de respiração]...Aí, ele saiu, porque ele é super educado. Aí, todo mundo ficou indignado e [falando como se fosse o pensamento de todos]... "a professora enlouqueceu, ...do nada ...!?!" Aí, eu falei "Professora, vamo conversar ali fora?" Eu chamei ela pra conversar lá fora porque os alunos também ficaram "Uai, professora, como assim??...do nada??"...Aí eu "Professora, vamo convesar aqui fora", tava lá na porta e falei "Vem cá, por favor, pra gente conversar?" ...E ela deu um grito "Você se ponha no seu lugar de aluna!!" e saiu da sala pra chamar a direção...Aí, meu sangue ferveu e... "Cara, caramba?!" [risos, cara de incrédula] Aí, a diretora chegou lá....Aí, sentou todo mundo e começou a conversar e, aí os alunos também, foi a hora que eles desabafaram "Que a professora não sabe ouvir!...que não sei o quê..." Eles disseram que ela não sabia ouvir. Aí tudo mais,...a diretora saiu e então a professora falou o que ela tava sentindo e tudo o mais. Aí, tá...Aí, eu fiquei quieta. Aí, no final da aula, assim, eu fiquei um pouco com consciência pesada. Eu tava. Eu pedi desculpa. Eu fui lá e pedi "Professora, desculpa, de eu ter interrompido a sua aula; quando eu chamei lá fora foi pra gente conversar ...porque eu queria evitar uma exposição [...] Aí ela, "Não tudo bem não sei o quê..." Aí ... [falando em tom de surpresa], passou duas semanas, teve a reunião do Conselho de Classe e um professor chegou em mim e falou que ela disse que eu era uma aluna atrevida (?!?!) ...E eu.. "Uai?!?!" Ela não entendeu que eu pedi desculpa e que eu não tava fazendo mais nada do que...eu não tava fazendo nada errado...e eu fiquei assim... "Ué, como assim??" Eles nos educam pra ser cidadões críticos e querem que a gente aceite tudo...Não sabem escutar. Então acho isso um pouco complicado.....Mas tirando isso, meu relacionamento com todos os professores eram bons.

Neste relato, com relação ao professor, frente à difícil tarefa de mediar o interesse dos alunos e na impossibilidade de diálogo com o professor que não explicou a matéria da prova, Camile toma a decisão de escrever a carta à direção que, ao invés de ser tomada como ponto de partida para possíveis negociações e entendimentos, não só não atinge o objetivo proposto como reforça a atitude prepotente e irônica do professor. No caso da discussão com a professora de Sociologia, percebemos a postura de confrontação de Camile em sua insistência em conversar em particular com a professora, em um momento de tensão. Insistência frente à qual a professora termina por recorrer à expressão "Você 
se ponha no seu lugar de aluna!!”. Aqui, mais uma vez, consideramos que a produção subjetiva de Camile no espaço escolar a constituía confiante e capaz de representar e confrontar a organização hierárquica da escola, de representar e defender os interesses dos alunos no grêmio e no Conselhor Escolar, e de mediar conflitos entre os atores escolares.

Ainda com relação ao contexto escolar, apontamos a postura crítica em várias de suas respostas aos exercícios das disciplinas de História, Filosofia, Geografia e Sociologia. Citamos como exemplo, sua resposta à pergunta sobre o tema de um texto de livro de Geografia intitulado "O capitalismo e a divisão internacional do trabalho (DIT)". De uma forma curta e simples, Camile responde:

O texto fala que o capitalismo transformou a economia em fonte de lucro, deixando de lado o atendimento das necessidades de uma sociedade, e que isso estabeleceu uma relação de subordinação [entre grupos sociais].

Em respostas como essa, interpretamos a autonomia crítica e a implicação emocional de Camile em determinados conteúdos de aprendizagem escolar por meio de sua capacidade de síntese e da fluidez de seu texto próprio, no qual não se preocupava em utilizar palavras difíceis ou formas rebuscadas de escrita.

Em nossas interpretações, este conjunto de informações consiste um indicador de sentidos subjetivos em Camile que se expressam em sua postura crítica e de confrontação que perpassam diferentes contextos de aprendizagem e que se constituíam como um núcleo de sentidos subjetivos da configuração subjetiva da ação do aprender no Projeto.

(2) A relação com a conturbada saída da escola de ensino médio

Várias informações da pesquisa nos permitiram interpretar que as atuações políticas na escola, a saber, no grêmio estudantil, no conselho de classe e como presidente de turma, resultaram, para Camile, momentos de forte implicação emocional. No completamento de frases (APÊNDICE D), ela cita:

6. Na escola as pessoas gostam de mim e eu delas.

28. Creio que minhas melhores atitudes são a compreensão, o carinho e a confiança que dou às pessoas.

41. Farei o possível para alcançar a minha felicidade e a das pessoas que amo. 
46. Luto por justiça.

Compreendemos, nas frases citadas, a tendência de Camile de se outorgar uma posição de responsável sobre as pessoas com as quais convive e tem afinidade. As frases 6 e 28 apontam a tendência de Camile em se envolver emocionalmente com seus colegas da escola, por meio de sentimentos de cuidado que foram também observados em sua resposta da entrevista semiestruturada II (APÊNDICE C), quando Camile é perguntada sobre o que mais gosta na escola: "Meus amigos. Me sentia como uma mãe. [...] Montava grupo de estudo, tava sempre incentivando. [..] Fico sempre pensando como eles estão agora sem mim."

A relevância que Camile confere a sua experiência no Grêmio transparece ainda, na entrevista semiestruturada II (APÊNDICE C), ao ser perguntada sobre conhecimentos e descobertas significativas a que chegou por si mesmo em sua vida escolar, Camile responde "[ter] senso crítico e reivindicar meus direitos." Nesta resposta, ao associar seus aprendizados na escola a sua atuação política na escola, consideramos a importância que Camile confere às suas atuações como líder do grêmio estudantil em sua escola.

Sobre esta atuação, chamou-nos atenção ainda o comentário que Camile publicou em sua rede social sobre o recebimento, em nome dos alunos da escola, do diploma de honra ao mérito, outorgado pela Câmara Legislativa do DF, em maio de 2013:

\footnotetext{
Muito gratificante poder receber esse Diploma de Honra ao Mérito em nome de todos os alunos do Centro Educacional 02. Me senti muito honrada hoje; vi que meu esforço e dedicação são reconhecidos, e que sou querida por muitos. Obrigada!
}

Se, por um lado, sentidos subjetivos relacionados às experiências de atuação política na escola lhe eram motivo de prazer, orgulho e autovaloração, por outro, e contraditoriamente, eles eram também motivo de autoavaliação, incertezas e angústias. Para essa interpretação, apontamos a enorme frequência com que as intensas e difíceis experiências surgiam espontaneamente em nossas interações informais de pesquisa. Em um desses momentos, já na universidade, visivelmente abatida e sentida, Camile nos colocou a questão com relação a sua atuação política na escola: "Será que fiz certo?" Ainda em outra conversa informal com a presença de um colega da escola, perguntamos, aos dois, suas respectivas sugestões de bons professores da escola. Em sua resposta, e dirigindo-se ao colega, Camile cita a fala de uma querida professora de Português que, ao 
saber de seu ingresso na Unb, lhe abordou dizendo "Viu, Camile, como tudo valeu a pena?", referindo-se à atuação política de Camile na escola. Pelo tom de Camile, e por aparecer em um momento em que é convidada a refletir sobre um bom professor, consideramos que essa fala da professora a marcou e confortou profundamente, da mesma forma como a confortou o apoio emocional do professor de Química, citado em seu relato da página 98, no momento da transferência de turma. A própria torrente de informações dos dois relatos, nas páginas 98 e 99, que se seguem a perguntas pontuais da entrevista, nos indica a ansiedade e a angústia relacionadas às lembranças dos eventos em seu último ano de escola. Dois meses depois de haver saído da escola, já na universidade, Camile nos expressa, também em conversa informal, a lembrança do conselho do professor de Química sobre "não se envolver com política na universidade".

Em nossas construções interpretativas, consideramos que este conjunto de informações nos permitem um indicador de que as intensas e difíceis experiências de atuação no grêmio estudantil, vividas por Camile em seus últimos meses na escola, consistiram em si um núcleo de subjetivação que participou da configuração subjetiva da ação do aprender no Projeto. Integram este núcleo, sentidos subjetivos relacionados a sua relação com os colegas, a sua relação com a hierarquia escolar, a processos de autorreflexão e autoavaliação, e às expectativas sobre a nova vida na universidade.

Por todas essas informações, interpretamos que precisamente os últimos seis meses na escola e o primeiro semestre na universidade, que coincidiram tanto com o Projeto quanto com a nossa pesquisa, foram um período de intensas e profundas autorreflexões de Camile sobre a legitimidade de suas atuações políticas e sociais. Interpretamos, por fim, que sentidos subjetivos em relação a este núcleo de subjetivação não só constituíram sua configuração subjetiva da ação do aprender no Projeto como contribuíram, significativamente, para definir a relevância e qualidade de suas aprendizagens neste contexto. Aprofundaremos essa análise mais adiante.

(3) O reconhecimento social, no contexto do Projeto, de suas experiências de atuação no grêmio estudantil e no movimento social

Em nossas análises, consideramos que o grande valor que todo o grupo de participantes do Projeto conferia às experiências de Camile, de atuação política na escola e no movimento social de sua cidade, adquiriam relevância em Camile. 
Citamos um fato ocorrido em um encontro do Projeto, antes das férias de julho, em que foi discutido o cronograma dos encontros finais de agosto para a preparação para o Fórum Ciência e Sociedade. No momento da definição do cronograma, após a apresentação de sugestões por parte dos monitores e do consenso de todos, Camile, ao final, expressa sua crítica ao número de encontros, que considera pouco e insuficiente para a preparação do evento. Remetendo-se a sua experiência de organização do encontro do movimento social do qual participa, descreve então, pormenorizadamente, uma longa lista de atividades necessárias para a organização do evento. Ao final de sua consideração, todos terminam por concordar com ela e por alterar e acrescentar novos encontros. Interpretamos que, em sua atitude, sua relação com sua experiência no movimento social contribui para diferenciá-la do resto dos participantes, conferindo sentimentos de autonomia, autoconfiança e audácia. Com efeito, com frequência Camile fazia referência a sua experiência na organização de reuniões, debates, votações e de eventos.

Vale ressaltar que, em nossas análises no contexto escolar, esta autovaloração baseada em um reconhecimento social se dava no valor que Camile conferia ao seu histórico de sucesso acadêmico. Na entrevista semiestruturada I (APÊNDICE B), ao ser perguntada sobre as experiências mais valiosas da vida, a primeira experiência citada por Camile se refere ao momento em que uma professora da segunda série lhe sugeriu avançar uma série tendo em vista seu nível intelectual e acadêmico. Segundo Camile, "essa professora foi muito importante para mim, isso sempre volta na minha cabeça." $\mathrm{Na}$ entrevista semiestruturada II (APÊNDICE C), ao ser perguntada sobre como se sente em relação às provas, Camile aproveita a oportunidade para relatar que na "Prova Interdisciplinar", preparatória para o vestibular, foi a aluna que tirou a maior nota de toda a escola. Neste mesmo instrumento, ao ser convidada a citar três experiências marcantes na escola, Camile novamente cita, em primeiro, a professora da segunda série; em segundo, cita o momento em que recebeu, em nome de todos os alunos da escola, o diploma de honra ao mérito, outorgado pela Câmara Legislativa, pelos "relevantes serviços prestados à S. [sua cidade]"; e, por fim, em terceiro, cita o fato de ter passado no vestibular. As três experiências citadas referem-se ao reconhecimento social sobre seu desempenho o que nos indica, indiretamente, o valor desse aspecto na produção subjetiva de Camile nos espaços sociais em que atua e nas tarefas em que se envolve. 
Em nossas interpretações, as informações de pesquisa nos permitem a construção de um indicador de que o reconhecimento social, no contexto do Projeto, de suas experiências de atuação no grêmio estudantil e no movimento social, conformou-se como um núcleo de sentidos subjetivos que ganha especial relevância na configuração subjetiva da ação do aprender em Camile, tendo em consideração a articulação deste núcleo com o núcleo de sentidos subjetivos relacionados à conturbada saída da escola e os processos de autorreflexão em Camile sobre a legitimidade de suas atuações políticas. Assumimos, aqui, mais uma vez, que essa complexa articulação de sentidos subjetivos em Camile, no contexto do Projeto, constitui e caracteriza seu forte envolvimento com o Projeto, sua motivação para aprender e a qualidade de sua aprendizagem neste contexto.

(4) A postura de flexibilidade e abertura para processos de aprendizagem

Por fim, consideramos que a aprendizagem, em geral, adquire um valor muito especial e particular em Camile, e que esse valor perpassou seus processos de aprender no contexto não-formal. Sobre esse aspecto, no completamento de frases (APÊNDICE D), ressaltamos as seguintes informações:

15. Tenho certeza que ainda preciso aprender muito.

51. Perguntar é o que mais faço.

52. Contradições são minhas amigas.

64. Quando tenho dúvidas pergunto ou tento descobrir sozinha.

Por meio dessas informações, interpretamos que a produção subjetiva de Camile frente à dúvida, à contradição, e ao "não-saber" é perpassada por sentimentos de prazer, coragem, audácia que nos permitem um primeiro indicador de sua postura de flexibilidade e de abertura para incorrer em processos de aprendizagem.

Ainda no completamento de frases (APÊNDICE D), Camile coloca:

68. O saber tem "sabor" quando trago a sabedoria para os meus dias. 69. Aprendo na escola, em casa, na rua, na igreja, na derrota, na glória.

Nestes trechos, consideramos que Camile valoriza o conhecimento formal, ensinado na escola e universidade mas, ao mesmo tempo, não o toma como limitado a esses espaços e não o reifica como "conhecimento obrigatório" mas como conhecimentos que a acrescentam como pessoa. Na entrevista semiestruturada III (APÊNDICE E), ao ser perguntada "O que é aprender para você?", ela responde 
[Aprender é] um processo de evolução, de crescimento de todo...um processo que já me acompanha na minha história...Eu acho que a gente nunca sabe de tudo, a gente vai mudando e aprendendo [...]

Vale destacar que, em especial no meio escolar do ensino médio, a concepção da aprendizagem por parte dos alunos consiste, de forma hegemônica, em um processo de apreensão e reprodução de conhecimentos. Como elemento da subjetividade social em relação ao ensino escolar, essa concepção se expressa nas subjetividades individuais dos alunos favorecendo, em formas singularizadas, a instrumentalização da aprendizagem e uma postura passiva e reprodutiva no processo do aprender, tendo em vista o sucesso no vestibular. No entanto, em contraposição a esse aspecto dominante da subjetividade social do ensino médio, Camile revela em sua resposta uma concepção de aprendizagem como um processo altamente pessoal, singular e dinâmico; no qual se inclui ativamente ao citar que se trata de "um processo que já me acompanha na minha história" e o qual foge da lógica instrumentalizante da aprendizagem escolar.

Em nossas elaborações, este conjunto de informações que expressam a representação de Camile sobre aprendizagem como processo de constituição pessoal nos consiste indicador de sua postura de abertura e flexibilidade na relação com processos de aprendizagem em geral.

Ainda outro indicador para essa construção teórica, se associa ao valor que Camile confere a seus próprios processos reflexivos. No completamento de frases (APÊNDICE D), ela coloca:

18. Meu maior professor foi meu espelho.

42. Frequentemente reflito sobre a vida.

49. O passado é importante bagagem que trago pros dias de hoje, é o que me faz ser o que sou.

71. Quando estou só durmo e reflito na vida.

Assumimos que a grande frequência de frases relacionadas à autopercepção de Camile como uma pessoa reflexiva nos indica, indiretamente, o valor que Camile confere a seus próprios processos reflexivos. Consideramos que esse valor recursivamente favorece uma postura de autoconfiança e coragem em se engajar em processos de aprendizagem e, como tais, em novos processos reflexivos.

Pelo conjunto de indicadores levantados, elaboramos que a relação que Camile estabelece com seus processos de aprender constitui um núcleo de sentidos subjetivos que 
participou da configuração subjetiva da ação do aprender em Camile no contexto nãoformal, favorecendo uma postura de abertura e de autoconfiança frente aos conteúdos e às situações de aprendizagem propostas.

Para finalizar esta seção, e de forma a sistematizar nossas construções interpretativas sobre os elementos da configuração subjetiva da ação do aprender em Camile no contexto não-formal, hipotetizamos que os aprendizados no Projeto se constituíram em meio a uma produção subjetiva, diversa e contraditória, tendo em vista as articulações entre sentidos subjetivos que se expressam no núcleo da conturbada saída da escola e no núcleo do reconhecimento social no contexto do Projeto, tendo em vista suas atuações político-sociais. Constituíram-se, ainda, em meio a sentidos subjetivos relacionados à expressão de elementos da subjetividade social em Camile, como o clima comunicacional e relacional do grupo. Em nossas construções, essa produção subjetiva contribuía para uma postura de autonomia, autoconfiança e audácia em suas atuações no âmbito do Projeto, favorecendo níveis de criatividade em suas aprendizagens nesse contexto. Aprofundaremos essa construção na seção a seguir.

\subsubsection{Características da Aprendizagem de Camile no contexto não- formal}

Na seção anterior, apresentamos nossas análises interpretativas sobre elementos da subjetividade de Camile que constituíam sua configuração subjetiva da ação do aprender no contexto não-formal favorecendo, em geral, uma postura de autonomia, de autoconfiança e de audácia nas situações de aprendizagem no contexto não-formal. Com efeito, reconhecemos que, em diversos momentos no Projeto, Camile expressou níveis de criatividade na aprendizagem, ou uma aprendizagem criativa, como sendo aquela em que o sujeito se orienta ativamente, para além da compreensão e da personalização da informação, à problematização, à transcendência e à elaboração de novas ideias. (MITJÁNS MARTÍNEZ, 2012).

A partir dessas características distintivas da aprendizagem criativa, analisaremos a criatividade na aprendizagem de Camile no Projeto, e seus processos subjetivos constitutivos. Com base em nossas construções teóricas realizadas no momento empírico da pesquisa, proporemos um novo processo subjetivo constitutivo: a personalização da 
experiência de aprendizagem. Acreditamos que este processo subjetivo adquire especial relevância no contexto não-formal estudado e representa um elemento novo ao campo teórico da aprendizagem criativa.

\subsubsection{Personalização da informação}

Conforme já apontado, assumimos por personalização da informação as formas com que a informação se integra à subjetividade do aprendiz, transformando-se em recurso subjetivo para diferentes contextos para além do contexto em que originalmente se apresenta. Apontamos processos de personalização da informação, em Camile, com base em três aspectos: a elaboração de sínteses pessoais sobre conceitos teóricos apresentados no Projeto, as formas personalizadas de registro das informações recebidas, e a frequência de reprodução de determinadas informações recebidas no Projeto, em contextos para além do contexto de aprendizagem.

Citamos, em primeiro, a forma com a qual Camile personalizou a concepção de saúde, conforme abordagem teórica adotada pelo Projeto, apresentada em especial no módulo II, Saúde e Educação. Em diversos momentos de nossas interações, tanto no período do Projeto quanto no período posterior a ele, observamos Camile expressar este aprendizado, a partir da atenção à multidimensionalidade do conceito de saúde. Apontamos, abaixo, alguns desses momentos seguindo uma ordem cronológica:

- Na entrevista semiestruturada IV (APÊNDICE F), Camile nos relata que, em março de 2013, em entrevista com a equipe de uma rede de TV, como atividade do Módulo III:

a repórter meio que perguntou para a gente o que a gente ia fazer no projeto e nessa época a gente não sabia direito [rindo]. Foi muito engraçado! [...] Mika falou que na escola dela tinha muitas grávidas; L. [outra colega] falou que a gente ia falar de prevenção; e eu falei um pouco da cultura hospitalocêntrica. [referindo-se à concepção comum da saúde como diretamente associada a serviços médico-hospitalares, em detrimento de uma visão mais ampla]

- Em final de março de 2013, na preparação para uma entrevista na escola como atividade do Módulo IV, Camile anota como lembrete para sua fala:

Quando falamos em saúde logo vêm à cabeça que definição da saúde é ausência de doença. Porém, segundo a Organização Mundial da Saúde (OMS), a definição de saúde é um estado de completo bem estar físico, mental e social e não apenas a ausência de patologias. 
Os três tipos de saúde mais conhecidos são: física, mental e emocional. Mas sabemos que é preciso manter equilíbrio entre elas para que tenhamos uma vida feliz e saudável.

- Em agosto de 2013, em sua relatoria do DRP, Camile lista as percepções de saúde levantadas, fazendo a seguinte análise crítica:

(Ponto positivo) "Esporte como saúde"

(Ponto negativo) "Saúde, não como esporte"

- Em novembro de 2013, no instrumento da Redação (APÊNDICE G), três meses após o término do Projeto, Camile escreve com suas palavras a seguinte definição de saúde:

Como aprendido no Projeto [...], saúde é um conceito amplo, que deve partir da premissa de que esse total equilíbrio, esse bem-estar surge através da prevenção e da promoção da saúde.

Nos momentos descritos acima, consideramos que Camile expressa a personalização do conceito ampliado de saúde com base nas diferentes formas em que, a cada nova oportunidade, em diversos momentos do Projeto, sintetiza de forma altamente pessoal sua atenção à multidimensionalidade da saúde.

No caso da redação (APÊNDICE G), interpretamos que o uso do conceito ampliado como base de argumentação para seu posicionamento crítico sobre uma política de saúde pública no país nos indica, mais uma vez, seu nível de reflexão sobre este conceito. Interpretamos ainda que o tom de crítica, expresso na redação por meio de trechos tais como "essa bola de neve toda", "Porque não melhorar ou até mesmo recapacitar os profissionais daqui? Ou mesmo agir de forma mais intensa em projetos e medidas de prevenção das doenças e promoção da saúde[...]?”, nos consiste indicador da implicação emocional de Camile com a temática, expressando sentidos subjetivos relacionados ao núcleo de sentidos da postura crítica e de confrontação, na configuração subjetiva da ação do aprender no contexto do Projeto.

Outro exemplo de processos de personalização da informação consiste nas formas pessoais de registro da informação por meio de desenhos livres e coloridos como ilustrações de conceitos e conteúdos de aprendizagem no diário de bordo do Projeto. Em nossas análises deste diário, identificamos diversos momentos em que Camile se utiliza desta estratégia para a compreensão dos conteúdos. Abaixo, apresentamos alguns exemplos. 


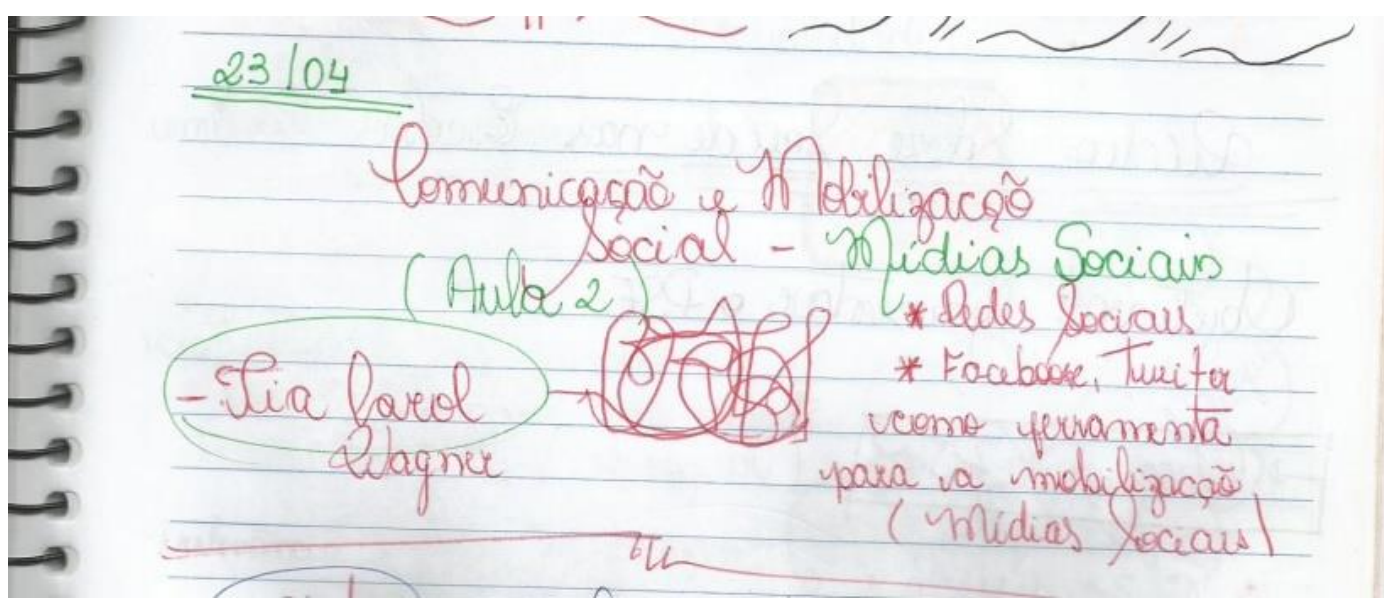

Figura 1: Rabisco representando a complexidade da comunicação nas redes sociais. (Módulo V: Comunicação e Mobilização)

\section{$25 / 04 / 8$}

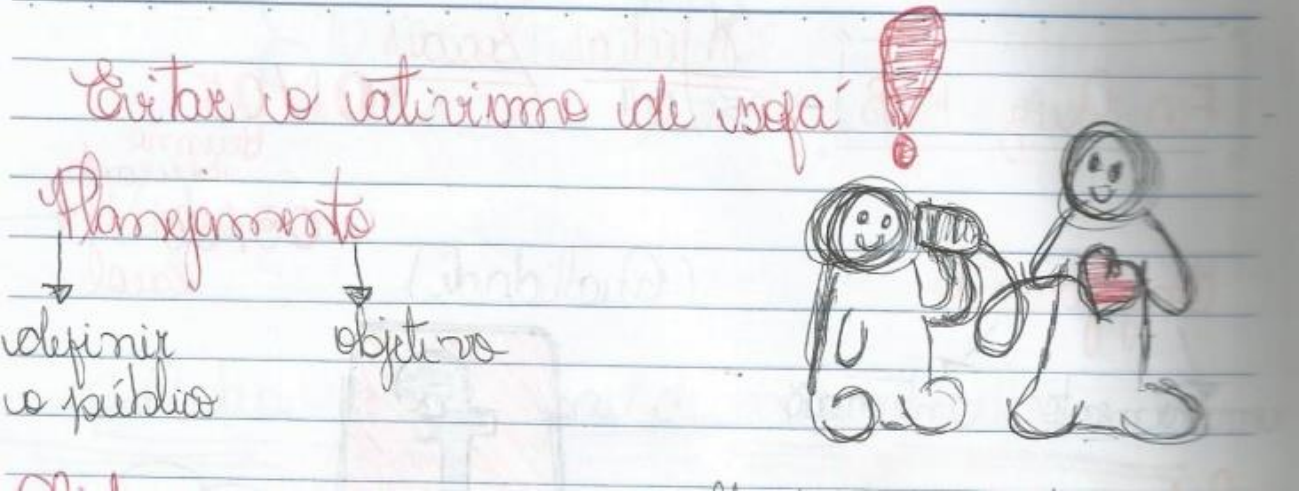

Figura 2: Desenho representando a ideia de que para evitar o "ativismo de sofá" e promover a mobilização cidadã é necessário sensibilizar a pessoa. (Módulo V: Comunicação e Mobilização) 

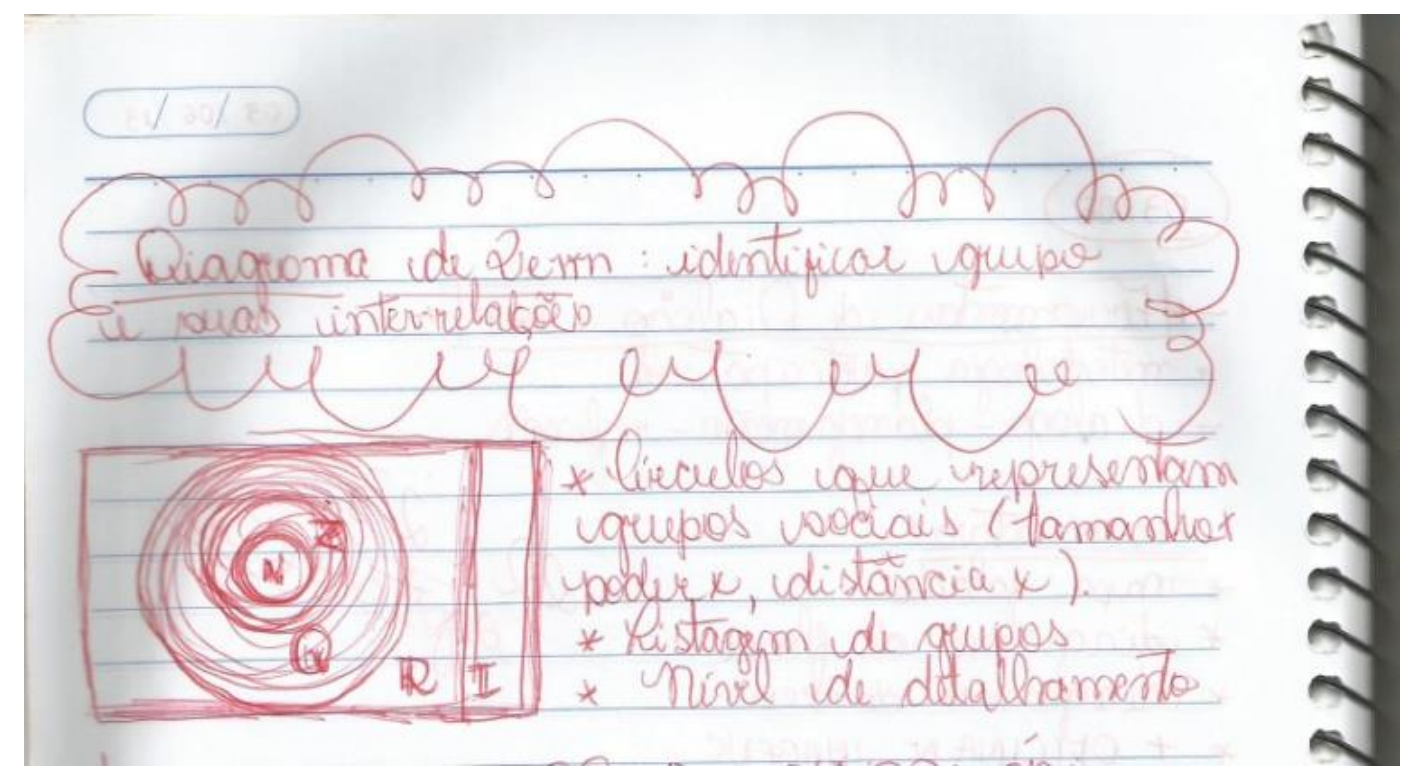

Figura 3: Desenho representando a ideia de Camile da representação de um Diagrama de Venn (Módulo VI: DRP)

Consideramos que o uso de desenhos como forma de registro de ideias envolve processos diversos, de reflexão, de síntese e de imaginação sobre conceitos e conteúdos; e se constitui, em Camile, como uma expressão de sua produção subjetiva no contexto da ação do aprender no Projeto marcada por aspectos de autovaloração, autonomia e audácia.

Vale ressaltar que esta estratégia de uso de desenho não foi, em nenhum momento, identificada em seus cadernos escolares e da universidade, marcados, no caso da escola, pela necessidade de cumprir com as demandas escolares e apresentar ao professor para avaliação sistemática e, na universidade, pela orientação para a reprodução e síntese das informações como estratégias para a compreensão dos conteúdos. Em contraposição, o uso de desenhos foi igualmente identificado na caderneta pessoal que Camile utilizava para registrar atividades do movimento social de sua cidade. Entre as informações registradas, observamos atas de reunião, registros de palestras, de votações, de encaminhamentos, entre outros. Interessante notar que Camile se utiliza dessa estratégia apenas em contextos não-formais e informais; o que, sob nossa abordagem teórica, resulta da expressão de sua organização subjetiva produzida nesses contextos, em diferenciação ao contexto formal, escolar e universitário. 
Por fim, citamos, como outro exemplo de processos de personalização da informação, os frequentes momentos em que determinadas informações recebidas, por Camile, eram reproduzidas por ela em contextos para além do contexto de aprendizagem. Este foi o caso de uma música de rap, apresentada no Módulo IV, Democracia, Participação e Protagonismo Juvenil, que consistiu uma informação de grande relevância para Camile em sua compreensão sobre a ideia de "protagonismo juvenil".

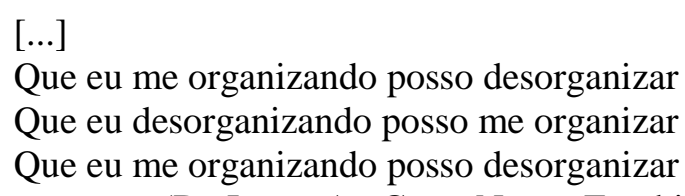

(Da Lama Ao Caos, Nação Zumbi)

Chamou-nos forte atenção o fato de Camile repetir este trecho seguidas vezes, em diversas ocasiões. Além de reproduzir esse trecho e a letra completa da música em seu diário de bordo e em seu portfólio, Camile cita-o em dois encontros de avaliação do Projeto. Camile volta a citar este trecho em nossa entrevista semiestruturada IV, em dezembro de 2013, realizada três meses após o término do projeto. Ao ser convidada a citar três grandes momentos de aprendizagem no projeto, Camile revela

[...] o que vem primeiro à cabeça foi o encontro na Regional de Ensino com a Profa. Celina, no dia que teve a apresentação da pecinha, mas foi a música mesmo que mais me marcou. A música da Lama ao Caos [...] Esse dia me marcou muito porque essa música fica na minha cabeça até hoje.

No início de 2014, aproximadamente seis meses após o Projeto, Camile publica o mesmo trecho da música em sua rede social. Interpretamos que o impacto desta música em Camile relaciona-se a sua própria experiência e interesse em se engajar em movimentos sociais e atuações políticas, tangenciando o tema do protagonismo juvenil abordado pelo Projeto.

Cabe ressaltar que a reprodução de frases de efeito, em especial de letras de músicas, é uma prática constante de Camile nas redes sociais. Em coerência com essa prática, tão comum na comunicação informal de Camile, identificamos em seu diário de bordo do Projeto, o uso recorrente de frases de efeito, que Camile anota em momentos de implicação emocional. Entre elas,

A juventude tem que pensar no presente, pois no futuro estaremos todos velhos. (Palestra Dr. Marconi; Módulo III)

Conheça seu bairro, conheça você, conheça o seu território. (Palestra Dr. Marconi; Módulo III) 
O conhecimento deve ser compartilhado, porque se não for, qual é o sentido das escolas? (Palestra Dr. Marconi; Módulo III)

No diário de bordo de Camile, essas frases foram seguidas de uma expressão de Camile, em letras grandes e vermelhas, "Run the World!!" (Liderar o mundo!!), que segundo ela, foi escrita em um momento seu de grande emoção e entusiasmo com a temática da palestra.

Em nossa análise interpretativa, consideramos que as formas de apresentação dessas informações, no decorrer do Projeto e a produção subjetiva de Camile, marcada conforme nossa análise anterior pela motivação e abertura à aprendizagem, favoreceram momentos de impacto subjetivo que, em Camile, contribuíram para a reflexão implicada e para a personalização dos conteúdos. Interpretamos que a palestra da Profa. Celina, em que ela foi apresentada à música "Da Lama ao Caos", e os momentos da palestra do Prof. Marconi que resultaram em sua escrita "Run the World!!", em seu diário, consistiram exemplos ilustrativos desses momentos de impacto subjetivo que favoreceram a forma como Camile subjetivou suas aprendizagens no Projeto com relação, por exemplo, ao conceito de protagonismo juvenil e a sua própria postura de atuação política e social.

Em decorrência, podemos pensar que processos de personalização da informação no contexto não-formal, de forma diferenciada de como ocorrem na sistemática e metódica aprendizagem do contexto escolar, estão mais associados à abertura do aprendiz para incorrer na experiência de aprendizagem e na forma como esta impacta subjetividade do aprendiz. Em outras palavras, na aprendizagem não-formal, momentos concretos de impacto subjetivo, ou de grande produção subjetiva, desdobram-se em reflexões personalizadas e criativas.

Como uma forma mais ampla e aprofundada da personalização da informação, como característica distintiva da aprendizagem criativa, apontamos a personalização do aprendizado. Buscamos enfatizar, nesta construção teórica decorrente das análises do momento empírico da pesquisa, as formas com que, não apenas a informação, mas as o próprio aprendizado resultante das ações e experiências vividas, se converte em novas ideias, representações, valores e atitudes que se integram, por sua significação para o aprendiz, à subjetividade deste, emergindo em momentos e contextos diferenciados do 
contexto de aprendizagem em si. Assumimos, a pertinência desta construção teórica para a compreensão da aprendizagem criativa no contexto não-formal. ${ }^{15}$

Com relação à personalização do aprendizado no Projeto, interpretamos, em Camile, que as informações sobre mobilização social, suas atuações no Projeto e sua experiência no Projeto se convertem em uma nova atitude sobre ações de mobilização política social que emergem em diferentes momentos e contextos posteriores de sua vida. Apontamos duas situações. Em primeiro, citamos o fato de Camile ser até hoje, aproximadamente dois anos após o início do Projeto, a principal mantenedora da página da rede social, criada para fomentar e divulgar informações sobre saúde nas escolas. Tal atividade exige uma atenção permanente a notícias, eventos, debates que se relacionam às temáticas do Projeto, entre elas protagonismo juvenil, saúde pública, saúde nas escolas, e disposição para divulgá-las e comentá-las em ambiente online. A manutenção atualizada de sítios na Internet não é tarefa trivial e, entre todos os participantes do Projeto, Camile tomou para si esta responsabilidade, de forma espontânea e automotivada.

Outro exemplo do envolvimento com atividades posteriores, diretamente relacionadas a sua experiência no Projeto, consiste a filiação de Camile, em fevereiro de 2014, ao grupo RadioWeb Saúde, um grupo de extensão da universidade, que desenvolve atividades sobre comunicação em saúde, fortemente relacionadas às temáticas do Projeto. Entre suas atividades, estão a realização de entrevistas com especialistas e a produção de matérias de jornalismo online.

Consideramos que essas atuações de Camile, posteriores ao Projeto, relacionamse à produção subjetiva constituinte da configuração subjetiva da ação do aprender em Camile, à forma como ela personalizou informações, tais como os conceitos de protagonismo juvenil e de comunicação e mobilização social, e à forma como personalizou sua própria experiência no Projeto.

Retomamos aqui, em especial, a produção subjetiva de Camile associada ao núcleo de sentidos subjetivos da conturbada saída da escola, caracterizado pela produção de sentidos subjetivos diversos e contraditórios com relação a suas atuações políticas no grêmio estudantil. Acreditamos que os aprendizados no Projeto, sobre comunicação e

\footnotetext{
${ }^{15}$ A pertinência da personalização do aprendizado para a análise da aprendizagem criativa no contexto não-formal será tratada, mais à frente, na seção da análise integrativa dos casos.
} 
mobilização social, se constituem em meio a esta produção subjetiva, reafirmando para ela a importância de suas atuações políticas e sociais, e fortalecendo sua motivação e sua autoconfiança para o contínuo engajamento em movimentos sociais e representações políticas.

Consideramos que as atitudes de Camile que se expressam em suas atuações, tanto de manutenção da página na rede social quanto de participação no grupo de extensão em comunicação e saúde, emergem como aprendizados do Projeto, não como transferências de conhecimentos assimilados, mas como expressão integral de mudanças em sua subjetividade resultantes das formas pelas quais ela subjetivou informações e experiências, em meio a uma configuração subjetiva que, como vimos, lhe favorecia processos de autovaloração positiva, de autoconfiança, de autonomia. Voltaremos a essa análise nas seções a seguir.

\subsubsection{A Confrontação com o dado}

Conforme já ressaltamos, com frequência, observamos em Camile uma postura de autonomia crítica frente às informações que lhe eram apresentadas ou surgiam durante um debate. Para além do diálogo transcrito na página 97, reproduzimos abaixo outro momento ilustrativo, ocorrido em um encontro em que 1o grupo realizava uma simulação da dinâmica do "Mapa Falado".

Monitor: Vocês sentem falta de alguma coisa lá? [referindo-se ao bairro onde moravam]

Participante 1: Hospital, sempre tem que pegar ônibus cheio.

Monitor: Vamo falá desse ônibus cheio...onde tem parada?

Participante 2: Tá sempre cheio [colocando papel na parada de ônibus da avenida principal do mapa]

Camile: A falta de hospital dá na superlotação do Hospital de S. A galera vem para o hospital para resolver coisas que não são de hospital. O hospital de S. atende $\mathrm{W}, \mathrm{X}, \mathrm{Y}, \mathrm{e}$ até $\mathrm{Z}$. [referindo-se a cidades do entorno] Uma vez eu tava entrevistando uma profissional do hospital que me disse "Eu tava com alergia e tive que pegar um documento no Centro de Saúde para ir para Ceilândia" [Outra cidade distante do distrito federal]

[Inicia-se uma longa discussão sobre os papéis institucionais do centro de Saúde e do Hospital] 
[Esgotada a discussão, após um longo silêncio...]

Camile: Mas essa realidade dos ônibus, né? Tipo assim, eu moro a dois kilômetros da escola e às vezes eu prefiro ir a pé do que ir de ônibus.

[Inicia-se uma longa discussão sobre a situação do transporte público.]

Percebemos que o diálogo se inicia com a discussão sobre a ausência de hospitais, mas logo se direciona para a questão problemática do transporte público no DF. Prendendo-se ao primeiro tema, que mais lhe interessa, Camile traz uma reflexão nova, um ponto à frente, sobre as causas da superlotação de pacientes. Retoma, assim, o primeiro tema e redireciona a discussão para a questão do papel dos hospitais e dos centros de saúde. Só depois de esgotado o assunto, a própria Camile retoma a questão do transporte público que inicia um novo e longo debate.

Consideramos que a recorrente capacidade de Camile de se confrontar com o dado, constituída em meio à uma produção subjetiva marcada pela implicação e pela autonomia e audácia nas situações de debate (onde mudava o rumo das discussões a bel prazer), assim como sua intencionalidade reflexiva na busca por novas perspectivas críticas, pela associação de ideias e pela geração de hipóteses explicativas sobre os temas em debate marcam, nos momentos evidenciados, o exercício de sua condição de sujeito que aprende, conforme categoria teórica de González Rey (2008, 2012).

\subsubsection{A geração de ideias novas}

Para além da reflexividade crítica, observamos momentos em que Camile fez associações novas entre ideias sobre conteúdos e conceitos abordados no curso de capacitação profundamente significativos para si. É o caso da forma como, na entrevista semiestruturada IV, critica o conceito de "protagonismo juvenil", apresentado no Módulo IV - Protagonismo Juvenil e Democracia, a partir de sua experiência de vida e de seu entendimento do conceito de "ativismo de sofá", apresentado no Módulo VI Comunicação e Mobilização Social, e Protagonismo Juvenil.

[ao falar sobre protagonismo juvenil...] Isso aqui ficou muito marcado em mim que era a questão do ativismo do sofá. [...] depois que aconteceram as manifestações [de junho de 2012] que eu vi que isso acontece de verdade. Tipo a galera só é ativista no computador. Fala "Ah! Não sei o que...temos que fazer a revolução!”. Tá, mas e aí? [risos] 
Consideramos que a crítica de Camile sobre o protagonismo juvenil que não se manifesta em ações práticas se relaciona a sua larga experiência com os desafios da mobilização estudantil no âmbito do Grêmio e do movimento social de sua cidade. Em várias interações no Projeto a ouvíamos reclamar da dificuldade de mobilizar os alunos da escola, tanto no âmbito do Grêmio, quanto no âmbito das demandas do Conselho escolar. Ressaltamos ainda a participação de Camile nas manifestações de rua de junho de 2012, em que segurava um cartaz com o dizer: "Uma juventude ativa é mais difícil de ser manipulada".

Acreditamos que Camile associa de forma criativa os dois os conceitos, de protagonismo juvenil e de ativismo de sofá, abordados em diferentes momentos do curso, e personaliza-os tendo em vista a forma como eles se relacionam ao seu próprio projeto de vida com relação a seu interesse em ações político-sociais.

Outro ilustrativo momento da criatividade de Camile na geração de ideias consistiu a forma como Camile construiu, para si e para todos os envolvidos no Projeto, a ideia da necessidade de uma mobilização para a retirada de pombos da rodoviária de sua cidade. Em vários e diferentes momentos do Projeto, essa ideia era retomada por Camile a partir de seu forte interesse pessoal.

- Em encontro do módulo III, PSE, em abril de 2013, na atividade do módulo de entrevista com professores e coordenadores da escola sobre questões de saúde na escola, no decorrer da entrevista, ao sugerir temática sobre questões ambientais, de forma a encaminhar a discussão Camile propõe o problema dos pombos, como exemplo.

- Em encontro do Módulo VI, DRP, em junho de 2013, durante a realização de uma simulação do "Mapa Falado", Camile volta a citar o problema dos pombos "São muitos, muitos, muitos, pombos. Todo o dia chega alguém batizado na escola”. Nesta simulação, sugere ainda como forma de amenizar o problema, que se cobre da prefeitura o uso de tampas nos tanques de lixo próximos à rodoviária e se desenvolva uma campanha de conscientização da população para não jogar lixo nas ruas.

- No Portfólio do Projeto, observamos em conjunto com vários outros materiais do curso, uma longa pesquisa na Wikipedia sobre pombos; 
- No encontro do Fórum Final, em agosto de 2013, na sistematização das conversas do Grupo de Trabalho em que Camile foi mediadora, mais uma vez encontramos a referência à questão dos pombos. Na carta de recomendações elaborada pelo grupo de trabalho e direcionada à Regional de Ensino, o tema foi incluído.

Apontamos aqui que a sugestão da questão dos pombos, o recorrente interesse, a pesquisa por informações extras e a busca pela mobilização de todos no longo decorrer do Projeto, demonstram uma implicação com o tema e com a experiência de aprendizagem, e consistem indicadores de uma produção subjetiva de motivação e autoconfiança que lhe permite ir além do que lhe era demandado e sugerido como atividade do Projeto.

Ainda outro exemplo de situação em que Camile transcende o que lhe é pedido e traz para as atividades do Projeto novas questões oriundas de sua própria reflexão e experiência transparece no relatório de análise das informações do DRP. Neste relatório, apresentado em detalhes no Fórum final, Camile inclui uma extensa lista de tópicos que não haviam sido tocados pelos participantes do DRP de sua escola, mas que são questões significativas para ela. No momento de sua fala no Forum final, direcionada a alunos, professores, diretores e profissionais da Regional de Ensino, Camile deixa claro que não se trata do resultado da pesquisa em si, mas que não gostaria de perder a oportunidade de abordar.

De forma análoga ao caso dos pombos, Camile não deixa de aproveitar oportunidades para, de forma pragmática e pró-ativa, trazer questões, novas e pessoais, demonstrando uma capacidade de reflexão, de imaginação e de audácia em processos que demonstram a relevância pessoal que Camile confere à sua crítica ao "protagonismo juvenil" que se limite a um "ativismo de sofá" e que nos indicam uma produção subjetiva que recursivamente alimenta sua autoconfiança e sua motivação para aprender e atuar em atividades de mobilização política e social.

\subsubsection{A personalização da experiência de aprendizagem}

Como elemento novo ao nosso arcabouço teórico de pesquisa, sugerimos a personalização da experiência de aprendizagem como um dos processos subjetivos constitutivos da aprendizagem criativa em contextos não-formais. Consideramos por 
personalização da experiência da aprendizagem as formas com que os processos do aprender, que se constituem na experiência prática e na reflexão sobre essa experiência, se integram à subjetividade do aprendiz. Nesse sentido, a criatividade da aprendizagem se expressaria tanto na geração de novas formas do fazer na experiência de aprendizagem, quanto na geração de novas ideias na reflexão sobre a experiência.

Conforme já colocado, a experiência com o Projeto previa a atividade de aplicação do DRP e análise das informações levantadas junto à comunidade escolar. Em nossas análises, consideramos que Camile expressou níveis de criatividade na aprendizagem tanto em sua atuação como mediadora da dinâmica de diálogo, quanto em sua reflexão sobre sua experiência. ${ }^{16}$

Observamos que Camile, em sua atuação na aplicação do DRP na escola, demonstrou-se uma grande mediadora, trazendo para a sua condução da dinâmica diversos novos elementos para além do que lhe haviam apresentado a priori. Entendendo profundamente o propósito da dinâmica, de conhecer a percepção de saúde da comunidade escolar, Camile se utilizou de estratégias diversas da atividade de mediar para obter um resultado satisfatório, entre elas: utilizava-se de humor; repetia instruções com palavras diferenciadas para a melhor compreensão do grupo; fazia perguntas provocadoras; dava tempo para reflexões; demonstrava uma escuta atenta às participações; sintetizava as falas e pedia confirmação como forma de reforçar a intervenção; provocava a participação dos participantes mais calados; interrompia educadamente falas longas; organizava a discussão pedindo para que cada um respeitasse a vez do outro; e perguntava a todos se estavam todos satisfeitos com as informações antes do fechamento.

A atuação de Camile no DRP demonstrou uma segurança e uma autonomia frente ao enorme desafio de mediar o debate entre colegas, professores e coordenadores pedagógicos de sua escola, em um processo que lhe exigia estar sempre atenta a detalhes da atuação dos participantes para "além da discussão" em si.

\footnotetext{
${ }^{16}$ Ressaltamos que o termo "mediadora" é aqui utilizado para descrever a ação que se esperava dos bolsistas do Projeto, no decorrer da dinâmica do DRP. Não nos referimos, portanto, à mediação pedagógica como o conceito teórico proposto no pensamento de Vigotski.
} 
Com relação a sua atuação como relatora da segunda dinâmica aplicada em sua escola, observamos que Camile fez grande uso de sinais e imagens para conseguir maior velocidade de registro. Observamos ainda que Camile não só relata comportamentos, mas já tece considerações sobre sua interpretação das informações registradas, adiantando-se à análise posterior do material. Descrevemos, abaixo, um de seus registros que expressa, já no momento da relatoria, sua análise interpretativa das informações que surgiam na dinâmica do grupo:

1. (Ponto positivo) "Esporte como saúde."

2. (Ponto negativo) "Saúde , não como esporte."

Posteriormente ao momento da relatoria, em suas análises, Camile seleciona e classifica os registros das falas, exemplificando suas categorias de positivo/negativo:

- “O esporte está ótimo , mas a saúde está péssima ." (2)

- "O esporte é bem incentivado . O atendimento no hospital é ruim." (2)

- "O esporte está bom, mas há a falta de capacitação profissional ." (2)

- "O esporte está bom , mas não há incentivo à saúde." (2)

- "O esporte é bom, a cidade é muito tranqüila." (2)

- "(Demorou a falar) $\mathrm{O}$ esporte é bom, e o negativo é que a administração anda investindo muito em shows e pouco em saúde." (2)

- Saúde não é só hospital, deve-se cuidar da saúde todos os dias." (1)

Consideramos que tanto em sua atuação como mediadora, quanto como relatora, Camile demonstrou profunda compreensão das tarefas propostas, um profundo envolvimento em suas execuções e a capacidade de ir além do que lhe era demandado, trazendo novos elementos que não haviam sido previamente apresentados. Assumimos que essas atuações se constituíram em meio a uma produção subjetiva que, conforme analisado na seção anterior, favorecia sua motivação, sua autonomia e sua audácia no contexto do Projeto.

Para além da criatividade na execução das práticas propostas no Projeto, consideramos que, na reflexão sobre a experiência dessas execuções, Camile demonstrou igualmente uma capacidade reflexiva que, de forma espontânea e auto-orientada, a permitiu um novo olhar sobre a ciência e sobre o fazer científico. Citamos como exemplo seu relato, na entrevista semiestruturada IV (APÊNDICE F), realizada três meses após o término do Projeto.

[o que mudou com a experiência no Projeto?] Exatamente no sentido do que a gente imaginava que ia fazer. Porque todo mundo pensava que a gente ia fazer pesquisa. Que ia ficar fazendo questionário. E depois a gente viu que não era nada disso. Que a gente fez na verdade uma pesquisa, mas foi assim...Tinha um preparo gigante, não foi do jeito que a gente 
imaginava. Pelo menos eu imaginava que tinha que ficar "Oi, não sei o quê...!" [gesticulando como se tivesse aplicando questionário]

Neste relato, de uma forma indireta, compreendemos que a expectativa inicial, sobre seu papel como participante do Projeto, relacionava-se a uma representação prévia da ciência e do fazer científico que, em nada se assemelhou com a experiência vivida. Com efeito, consideramos que foi a própria experiência de aplicação e análise do DRP, no âmbito do Projeto, que visava a compreensão sobre uma realidade social sob uma abordagem qualitativa de pesquisa, o que a levou a uma nova interpretação pessoal sobre o fazer científico e uma nova representação da ciência como uma dimensão mais próxima de sua realidade e de sua vida cotidiana. Representação na qual sentia-se mais incluída como pesquisadora, capaz de problematizar, interpretar informações e fazer análises de sua realidade, no caso a realidade escolar.

Nesse sentido, no contexto não-formal, compreendemos que a aprendizagem sobre uma nova representação da ciência, não consistiu na personalização da informação recebida sobre a ciência e o fazer científico, abordadas no Módulo VI do curso, mas a personalização da própria experiência de Camile no Projeto, considerando sua implicação emocional na condução das atividades previstas e sua capacidade reflexiva sobre sua experiência.

De forma a sistematizar nossas análises sobre as características da aprendizagem criativa de Camile no contexto não-formal, pontuamos que os momentos de criatividade na aprendizagem analisados apresentam alguns dos processos subjetivos constitutivos da aprendizagem criativa, conforme apontados nos estudos da área e salientados na parte teórica, capítulo III, deste trabalho. Entre eles, conforme apontado na análise, o exercício da condição de sujeito, a própria aprendizagem como configuração subjetiva, uma produção subjetiva que recursivamente alimenta para novas aprendizagens, a própria aprendizagem como configuração subjetiva e, por fim, no referente à dimensão funcional da aprendizagem criativa, uma produção subjetiva da ação no Projeto que favoreceu sua motivação e autoconfiança para a atuação política, de uma forma mais geral em sua vida, indicando processos de mudanças subjetivas em sua relação com essa atividade. Aprofundaremos essa construção na seção da análise integrativa dos casos. 


\subsection{A participante Estela}

\subsubsection{A caracterização de Estela e a expressão da subjetividade social do contexto não-formal em sua subjetividade individual}

Em nossas interações, percebemos em Estela uma pessoa inteligente, responsável, atenta e esforçada em nos responder aquilo que acredita ser o mais correto. Com frequência, Estela apresenta-se como sendo "muito certinha". Em nossa relação, demonstra-se sempre um pouco tímida no início das conversas, ganhando, porém, progressiva confiança, em especial quando fala sobre seus planos futuros.

Estela mora com os pais e o irmão mais novo; é muito unida à família e aos pais, a quem expressamente admira por aspectos como a prática religiosa e o fato de haverem juntos superado desafios tais como a baixa renda e o desemprego do pai. Estela tem a pele muito clara, olhos verdes e pinta o cabelo de loiro platino. Seu biotipo a diferencia da grande maioria de seus colegas tanto em seu bairro, quanto em sua escola, considerando a estratificação socioeconômica no país que confere a predominância de negros e pardos nas classes sociais mais baixas.

Estela tem paixão pelo estudo de francês; fala fluentemente e recebeu, em 2012, uma bolsa de estudo do governo francês por meio da qual passou um mês em Mônaco. A realização desta viagem ao exterior, aos 17 anos, sozinha, foi de grande significância para Estela influenciando sobremaneira, tanto seus planos futuros, quanto sua constituição subjetiva nos espaços de aprendizagem, conforme veremos a seguir.

Estela tem um ótimo desempenho acadêmico na escola, é muito querida dos professores e tem um grupo muito coeso de amigas. Cursa o terceiro ano do ensino médio, tem preferência pelo estudo de química e física, e pretende prestar vestibular para medicina ao final do ano. Expressa que deseja seguir carreira como neurocirurgiã e que tal determinação decorre da triste experiência de haver vivenciado o falecimento de sua querida avó. Estela planeja ainda se inscrever no Programa Ciências Sem Fronteiras e ter a possibilidade de realizar parte do curso superior na França. Não tem clareza ainda da 
faculdade para qual irá ou do real papel de tal experiência em sua formação acadêmica, mas demonstra especial interesse e animação frente à perspectiva de voltar à França.

\subsubsection{A configuração subjetiva da ação de aprender em Estela no contexto não-formal}

De forma similar ao caso de Camile, buscaremos analisar elementos constitutivos da configuração subjetiva da ação do aprender em Estela no contexto do Projeto nãoformal, centrando-nos em dois aspectos: (1) elementos de sentidos subjetivos relacionados à expressão da subjetividade social do contexto do Projeto na subjetividade individual de Estela; e (2) núcleos de sentidos subjetivos organizados na trajetória de vida e no momento atual de Estela.

\subsubsection{Elementos de sentidos subjetivos relacionados à subjetividade social do contexto não-formal}

Retomamos, aqui, os elementos da subjetividade social do grupo do Projeto, apresentados no caso de Camile, que se expressavam: (1) na consideração pelo Projeto como oportunidade privilegiada e (2) na relação com o clima relacional e comunicacional de abertura e confiança do grupo. Consideramos que esses elementos da subjetividade social se expressavam de forma singular na subjetividade individual de Estela, em complexa articulação com outros elementos subjetivos produzidos por ela no contexto não-formal.

Com relação à consideração pelo Projeto como oportunidade privilegiada, na análise de seu caderno escolar, em questionário aplicado como exercício da disciplina de sociologia, frente à pergunta “Que papéis você representa na sociedade?", Estela responde "Sou estudante; trabalho com pesquisas na Instituição F.". Interpretamos, neste trecho de informação, que a participação no Projeto relaciona-se, em Estela, a sentidos subjetivos associados ao status social de ser uma pesquisadora da instituição e ao valor que Estela confere a este aspecto. Em outro momento, em conversa informal, Estela relata ter sido reconhecida por colegas na escola como representante do Projeto e de haver sido procurada por um jornalista para dar um depoimento sobre o Projeto. Nesta ocasião, Estela menciona, rindo com prazer: "Agora somos famosas! Todos querem falar com a gente!". 
Tais informações nos permitem construir um indicador do valor que Estela confere ao reconhecimento social advindo da participação no Projeto e, neste viés, de sua consideração como oportunidade privilegiada. Ressaltamos que entre os diversos aspectos que pudessem consistir fontes de sentidos subjetivos tais como o processo de seleção e o mérito dos escolhidos, os recursos financeiros da bolsa de pesquisa, a oportunidade de aprendizagem em uma área sobre saúde, foi precisamente o reconhecimento social advindo de sua participação no Projeto, em especial na sua escola, o que pareceu ser o aspecto de maior significância para Estela. Consideramos que esse aspecto de sua produção subjetiva relacionada a este elemento da subjetividade social favorecia sentimentos de prazer e de implicação no Projeto.

Com relação ao clima relacional e comunicacional de abertura e confiança do grupo, consideramos que este elemento da subjetividade social se expressa na subjetividade individual de Estela por meio de sentidos subjetivos associados à relação com o grupo, com os monitores do Projeto e com o fazer pedagógico. Conforme Estela coloca:

Todos deram espaço para mostrar nossa opinião. [A gente] nunca era avaliado. A gente fazia o nosso mundo; não era certo ou errado; era a nossa reflexão. [...] Tive tanto contato com tanta diversidade. Será que a minha cultura está certa? [...] (Entrevista semiestruturada IV-APÊNDICE F)

Interpretamos, neste trecho, que sentidos subjetivos associados ao clima comunicacional do grupo eram, em Estela, perpassados por sentimentos de surpresa pela ausência de avaliação formal; o que, indiretamente, nos indica a importância para Estela deste aspecto em contextos formais de aprendizagem. Interpretamos ainda sentidos subjetivos associados a "não familiaridade" com o nível de espontaneidade e de liberdade de opiniões experienciadas nos encontros do Projeto.

Com efeito, em muitos encontros, observamos o debate sobre assuntos socialmente polêmicos, tais como a liberação da maconha, a internação compulsória de usuários de rua de crack, o sexo e a gravidez na adolescência, entre outros. Não raro, alguns do grupo, incluindo os monitores, se manifestavam abertamente a favor de posições arrojadas, inovadoras e revolucionárias, em nossa compreensão, contrastantes com os valores éticos, morais e religiosos dentro dos quais Estela foi criada. Em nossas observações, durante esses debates, comportamentos de Estela tais como seu silêncio, seus sorrisos tímidos, suas opiniões pessoais e sua grande atenção, nos indicavam sua 
surpresa pela forma como essas temáticas eram discutidas e sua admiração pelo trabalho pedagógico dos monitores.

Em nossas construções, este conjunto de informações nos consiste um indicador da forma singular com que Estela subjetivava o clima relacional e comunicacional do grupo, marcada pela forte comparação e diferenciação do contexto escolar, com o qual tinha mais familiaridade e se sentia mais confortável, e pela surpresa no contato com pensamentos diversos. Consideramos que este elemento da subjetividade social do grupo na subjetividade individual de Estela se associava ainda a sentidos subjetivos relacionados à dificuldade de se posicionar como aluna no contexto não-formal, à novidade das temáticas nas discussões e debates e a sua própria relação com seus valores éticos e morais. Ressaltamos, portanto, a forma singular com que este elemento da subjetividade social do grupo se expressa na subjetividade individual de Estela. Ressaltamos ainda a dominância deste elemento subjetivo na constituição da configuração subjetiva da ação do aprender no contexto do Projeto, em Estela. Interpretamos que este elemento subjetivo contribuiu significativamente para a emergência da criatividade em sua aprendizagem. Aprofundaremos essa análise a seguir.

\subsubsection{Núcleos de sentidos subjetivos organizados a partir da trajetória de vida e na ação de Estela no contexto não-formal}

Em articulação com os elementos de sentidos subjetivos relacionados à subjetividade social do Projeto, núcleos de subjetivação, organizados na trajetória de vida e na ação do aprender de Estela no contexto não-formal, integraram, em nossas elaborações, a configuração subjetiva da ação do aprender nesse contexto. Entre eles, núcleos de sentidos subjetivos que se expressavam: (1) na sua relação com o seu conhecimento e aprendizagem da língua francesa; (2) na determinação para seus sonhos e projetos futuros; (3) na necessidade de aceitação social e do reconhecimento social de seu desempenho; (4) em sua relação com a avó e com a família e (5) na relação com a aprendizagem como processo obrigatório. Analisamos, a seguir, cada um deles.

(1) O conhecimento e aprendizagem da língua francesa 
Conforme mencionado, Estela fala com fluência a língua francesa. Adora aprender esta língua, tem uma bela pronúncia e se orgulha disso. No instrumento de apresentação da pesquisa (APÊNDICE A), ao ser perguntada se tem paixão por aprender alguma coisa, Estela responde com um enorme sorriso "Aprender francês! É o melhor momento da semana." Relata ainda que não gosta quando o professor fala português na aula, reclama que as conversas em sala deveriam ser em francês. Para além das aulas de francês, percebemos nos cadernos da escola e no diário de bordo do Projeto que, com frequência, Estela se utiliza de palavras em francês para organizar o conteúdo. São comuns, em seu caderno, palavras tais como: "Questionnaire”, "Réponses”, Pour Le cours prochain”, "Théme", entre outras.

Em seu dia-a-dia, Estela ouve músicas francesas em seu celular; vê filmes e lê livros franceses. No Fórum Ciência e Sociedade 2012, tivemos a oportunidade de vê-la atuando como tradutora e mediadora das interações entre os estudantes e pesquisadores franceses e brasileiros. Em muitos momentos liderava os debates, tomando para si a palavra e promovendo participações. Estela, ao falar francês, sente-se segura, ganha autoconfiança. Tem consciência que pouquíssimas pessoas do seu convívio social, seja na escola, seja em casa ou na igreja, possuem tamanha fluência em uma segunda língua estrangeira tão estimada socialmente.

A diferença social do "falar francês" assume ainda uma relação com seu biotipo: sua pele clara, seus olhos verdes e seu cabelo de louro platinado. Com frequência, ela usa uma boina na cabeça e, nos dias frios, cachecol. Interpretamos que sentidos subjetivos relacionados ao conhecimento da cultura e da língua francesa participam de seus processos identitários, marcados por processos de aproximações e distanciamentos a grupos sociais dos quais conhece e/ou participa; sejam eles na França ou no Brasil, na escola, na igreja ou em seu bairro.

A forma como Estela subjetiva sua viagem a Mônaco nos consiste outro indicador da língua e da cultura francesa como elemento de sua organização subjetiva. Em um dos encontros do Projeto, foi realizada um dinâmica em que os participantes eram convidados a pensar em uma viagem imaginária para um lugar ao qual gostariam de retornar. Eram então solicitados a dizer para onde gostariam de ir, o por quê, o que gostariam de levar 
na bagagem e que conhecimento gostariam de ensinar às pessoas presentes neste lugar. Nesta ocasião, o lugar escolhido por Estela foi Mônaco. Seu motivo é ter "adorado" sua experiência lá. Estela desenvolveu grandes amizades no decorrer desta viagem, com as quais se corresponde até hoje.

Creditamos a essa experiência de Estela, quatro aspectos: em primeiro, o quanto ela confere uma lembrança positiva e privilegiada à experiência da viagem. Em segundo, a experiência de autonomia e independência vivenciadas. Em terceiro, o valor social que a ida à França adquire em seu meio social. E quarto, por fim, a influência dessa experiência em seus desejos e planos atuais de voltar à França. Como já colocado, Estela pretende passar no vestibular para o curso de medicina e se inscrever no programa Ciências sem Fronteiras para estudar na França. Para tais objetivos se encontra extremamente focada e determinada.

Este conjunto de informações nos permite a construção interpretativa de que, em Estela, o conhecimento e a aprendizagem da língua francesa transcendem a simples aprendizagem instrumental de uma segunda língua estrangeira, ganhando um significativo valor simbólico-emocional, perpassado por sentidos subjetivos diversos associados a sentimentos de autoconfiança, de autovaloração, de autoestima, de prazer pela aprendizagem da língua, e de autodeterminação e interesse pelo estrangeiro.

Consideramos que este núcleo de sentidos subjetivos integra a configuração subjetiva da ação do aprender no contexto não-formal. Apontamos, como indicadores para essa construção, as diversas participações de Estela nos encontros do Projeto, em que ela trouxe relatos de suas experiências em Mônaco como exemplos ilustrativos em discussões sobre políticas de prevenção de drogas, sobre o hábito de fumar na França, sobre o transporte público, entre outros. O uso constante de expressões em francês em seu diário de bordo e no portfólio para a organização e compreensão do conteúdo abordado e as eventuais conversas com especialistas da Instituição F., em francês, nos consistem ainda outros indicadores

Consideramos, no entanto, que o conhecimento e a aprendizagem da língua francesa como núcleo de sentidos subjetivos ganha força hegemônica na configuração subjetiva da ação do aprender em Estela no contexto da escola, constituindo de forma significativa sua motivação para a aprendizagem escolar em decorrência da 
obrigatoriedade da realização do ensino médio para o alcance de seus planos de ingressar no ensino superior e estudar no exterior. Aprofundaremos essa análise a seguir.

\section{(2) Determinação para seus sonhos e os projetos futuros}

Conforme já apontado, o momento atual de vida de Estela é marcado por uma forte relação com seus sonhos e projetos futuros. No completamento de frases (APÊNDICE D), Estela coloca:

11. Meu futuro é tão imprevisível quanto meu presente.

16. Minha preocupação principal é de não conseguir realizar meus objetivos.

20. Eu sou sonhadora e ambiciosa.

24. Minha principal ambição é ser sempre melhor em tudo.

27. Quero ser independente.

29. Nesse ano letivo conquistei várias coisas.

31. Considero que posso sempre dar o meu melhor.

32. Esforço-me diariamente pelos meus estudos.

34. Meu maior desejo é ter meus estudos completamente (desde o colegial até o doutorado.

35. Sempre quis ser rica.

37. Minhas aspirações ser médica, ajudar as pessoas.

38. Meus estudos me farão ir além.

40. Minha vida futura pertence a Deus.

41. Farei o possível para alcançar tudo que já sonhei e ainda vou sonhar.

42. Frequentemente reflito sobre o meu amanhã.

44. Meu maior tempo dedico ao estudo e a família.

46. Luto por mim.

60. Sinto pena daqueles que não sonham alto.

65. No futuro pretendo me surpreender com meu presente.

69. Aprendo na escola algumas coisas que me servirão para o futuro.

70. Odeio quando me impedem de fazer alguma coisa.

74. O estudo é tudo o que tenho.

O grande número de frases relacionadas aos seus sonhos e projetos futuros nos pareceu, em si, um indicador da força desses elementos em sua constituição subjetiva atual. Nas frases, interpretamos a produção de sentidos subjetivos diversos relacionados à preocupação com o futuro e à incerteza do sucesso no vestibular e ingresso na universidade $(11,16,20,34,40,42)$, ao desejo de uma carreira profissional consolidada e valorizada e de independência financeira $(27,35,37)$, à ambição e determinação com relação aos seus objetivos $(24,31,41,46,60,65,70)$ e à representação do estudo e da aprendizagem como meios para o alcance de seus objetivos $(29,32,38,44,69,74)$. 
Consideramos ainda que perpassam esta produção subjetiva sentimentos diversos e contraditórios de pressão, de angústias, de determinação, de autoconfiança, de audácia.

Ressaltamos a sequência direta das frases 34 e 35, 37 e 38 como indicador da forma como os processos de subjetivação em Estela articulam o estudo e a aprendizagem ao alcance de seus sonhos e projetos futuros. Com efeito, interpretamos, em Estela, uma tendência, consciente e inconsciente, a instrumentalizar o estudo e a aprendizagem em função de seus objetivos. Sua resposta sobre a diferença entre aprender no Projeto e aprender no contexto escolar nos consiste outro indicador para esta interpretação.

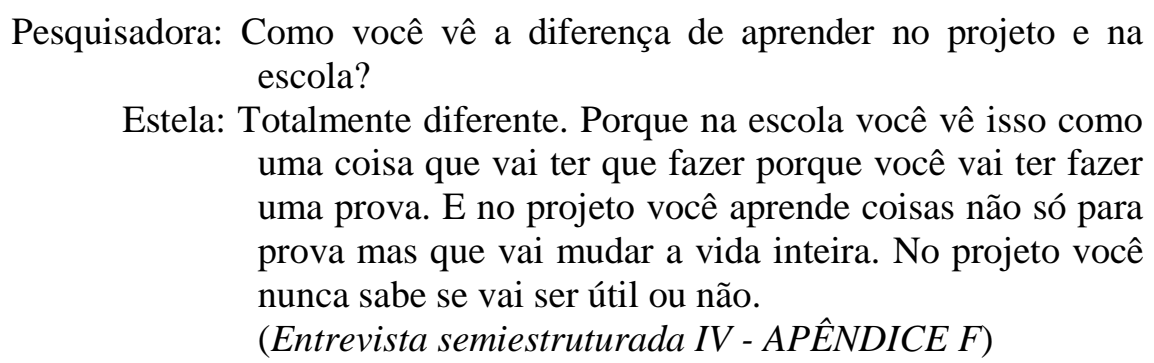

Consideramos que, ainda que busque afirmá-lo de forma contrária, essa resposta de Estela nos remete indiretamente à ênfase que ela confere à utilidade da aprendizagem e à importância em se sair bem em provas. A relação entre o estudo e os planos futuros em Estela não passa desapercebida pelos seus colegas. Em entrevista com uma das monitoras do Projeto, apontamos o seguinte relato:

[Estela] é responsável; tem uma meta a atingir e segue direitinho aquele caminho; tudo é certinho e sistematizado. Camile e Mika [as outras duas participantes desta pequisa] já não seguem bem as regras. (Entrevista com monitores - APÊNDICE H)

Com base neste conjunto de indicadores, elaboramos que a forte determinação de ingressar na universidade e viajar para o exterior, consistia, em Estela, um núcleo de subjetivação que se integrava tanto à configuração subjetiva da ação do aprender no contexto do Projeto, quanto à configuração subjetiva da ação do aprender no contexto da escola; ambas constituindo processos diversos de motivação para o estudo e aprendizagem, de organização de seu comportamento e de sua postura como aprendiz, tanto no contexto escolar quanto no contexto do Projeto. 
Interpretamos, no entanto, que a participação deste núcleo na configuração subjetiva da motivação para o aprender em Estela, no contexto Projeto, ganha menor relevância tendo em vista a não relação direta entre o Projeto e a entrada na universidade e, subsequente, viagem de estudo ao exterior.

Por fim, ainda com relação a seus sonhos e planos futuros, interpretamos que o interesse de Estela pela carreira médica relaciona-se mais à representação que Estela faz de uma profissional em medicina do que propriamente à prática profissional em si. $\mathrm{Na}$ entrevista semiestruturada I (APÊNDICE B), ao ser perguntada sobre quais são seus projetos e sonhos, Estela responde

Ser médica [...], casar e ser bem estruturada; amar e ser amada, respeitar e ser respeitada; [...] estudar fora: Cuba, França, Canadá; uma experiência nova, né? Gosto do novo [...]".

Nesta resposta, interpretamos que o interesse de Estela pela prática médica, ou pelo prazer da aprendizagem de conhecimentos e conteúdos da área médica, não se destaca em relação ao seu interesse em se estabelecer socialmente, o que inclui seus desejos de uma carreira profissional promissora, de independência financeira, e de ir para o exterior.

\section{(3) A necessidade de aceitação e do reconhecimento social de seu desempenho}

Em nossas análises, as informações construídas na pesquisa nos levaram a elaborar sobre o valor que a necessidade de aceitação social e de reconhecimento social de seu desempenho na sua relação com o outro adquire em Estela. No completamento de frases (APÊNDICE D), apontamos as seguintes informações:

28. Creio que minhas melhores atitudes são: ajudar as pessoas, fazê-las sorrir e dar orgulho à todos.

48. Diante de situações novas eu tento refletir e me adaptar.

61. Quando crio algo novo mostro à todos.

Interpretamos, nestes trechos, sentidos subjetivos associados à permanente atenção à avaliação do outro (61), à necessidade de se integrar a um grupo (28) e ao medo de se diferenciar (48). Na entrevista semiestruturada II (APÊNDICE C), ao citar três momentos marcantes da vida escolar que gostaria de reviver, Estela cita: em primeiro, o Projeto sobre Síndrome de Down, que realizou na Feira do Conhecimento de 2012 na 
escola e no qual seu grupo obteve nota máxima; em segundo, quando passou no Desafio National Geographic, a maior olimpíada de geografia do Brasil; e, em terceiro, quando ganhou um troféu pela Olímpiada de Matemática. Todos os três momentos citados referem-se a ocasiões de reconhecimento social por seu desempenho acadêmico.

O valor que Estela confere à necessidade de aceitação e reconhecimento social transparece ainda quando, na entrevista semiestruturada III (APÊNDICE E), frente à pergunta “Quando você se sente animada a aprender?”, estela ela responde:

Sou uma pessoa aberta; converso muito com as pessoas. Gosto muito quando o professor está empolgado. [...] A minha professora de química, você erra e ela te corrige de uma maneira doce. [...] Não gosto de professores que passa a ideia de que são superior, não fico à vontade para aprender. [...] quando converso com meu tio, eu tenho um tio que é advogado. [...] Toda a vez que quebra a hierarquia me sinto animada a aprender.

Compreendemos, neste relato, a importância que Estela confere a agradar e a estar de acordo com o esperado; assim como seu desconforto em ser corrigida e/ou em receber críticas. Interpretamos, neste conjunto de informações, um indicador da necessidade de aceitação social e de reconhecimento social de seu desempenho como um núcleo de sentidos subjetivos em Estela.

Apontamos ainda os seguintes relatos de autoavaliação de Estela como relevantes para essa construção interpretativa:

Sou uma boa aluna; não sou uma das melhores mas estou sempre entre as melhores" (Entrevista semiestruturada II - APÊNDICE C).

No primeiro ano do ensino médio, não tinha uma boa base de física e química estudava nas férias, de madrugada, sozinha, [...] Mas depois, na sala de aula, eu sabia mais que todos e foi superlegal". (Entrevista semiestruturada III - APÊNDICE E)

Consideramos que o comportamento de Estela de permanente comparação com outros como forma de se autoavaliar nos consiste ainda outro indicador para a construção deste núcleo de sentidos subjetivos em Estela.

Nossas análises sobre o forte valor que Estela confere à avaliação social nos levaram ainda a interpretar que, relaciona-se a este núcleo de subjetivação, a dificuldade 
de Estela em atuar em situações de improviso. Com efeito, no contexto do Projeto, a aplicação do DRP em sua escola consistiu para si um enorme desafio. Estela nunca havia mediado um debate; e, muito menos, participado dessa mediação enquanto pesquisadora. Em nossas observações, durante o DRP, Estela mostrou-se particularmente nervosa; sua voz não transmitia segurança e olhava com frequência para os monitores de forma a comprovar as instruções que apresentava. No decorrer dos debates, Estela teve grandes dificuldades em encontrar o equilíbrio entre incentivar e controlar as participações. A autoavaliação como mediadora do DRP nos consiste ilustrativa.

Estela: Foi horrível!! [...] Eu aprendi que eu tenho que brincar mais. [...] Eu sou o tipo de pessoa que sou muito perfeccionista, então quando a situação não consegue ser controlada...Os meninos eram muito, muito difíceis...

Monitores (juntos): - Mas foi tão bom! Foi um sucesso! [...] Vocês conseguiram tanta informação! [...]

Estela: - Eu sou muito perfeccionista e...se eu estou muito calma é porque eu estou muito nervosa.

Ainda em momento de avaliação do DRP expressa:

[...] porque sou muito tímida. Tinha que deixar todo mundo falar e, ao mesmo tempo, tinha que controlar.

Em um encontro de preparação para o Fórum, onde os participantes do Projeto iriam mediar a discussão nos grupos de trabalho, Estela comenta:

[Coloca a mão na boca, mexe negativamente a cabeça e ri nervoso.] $\mathrm{Ai}$, Meu Deus, a gente vai ter que mediar de novo??

A aplicação do DRP, por consistir uma atividade tão diferenciada das atividades escolares ao não exigir a simples exposição de um conteúdo estudado mas a mediação de um debate, pareceu-nos tirá-la de sua zona de conforto. Já em suas apresentações e participações no Fórum Juventude pela Saúde, ainda que destinadas a uma plateia ampla de pesquisadores especialistas, alunos, professores e de dirigentes políticos, voltamos a perceber Estela em seu lugar de conforto, apresentando a todos o resultado de suas análises com a fluência oral que lhe é característica como aluna exemplar. Na entrevista semiestruturada IV (APÊNDICE F), com o auxílio do Portfólio, apontamos o diálogo sobre a avaliação do DRP:

Pesquisadora: [...] O módulo VII, o DRP. Eu sei que vocês falaram tanto que foi uma experiência tão difícil [risos] 
Estela: [risos] Foi.

Pesquisadora: Mas vocês acham que ficou alguma experiência positiva, boa de alguma forma?

[Tempo]

Estela: Foi...diferente...[risos] Foi diferente! Quando eu falo positivo é porque eu nego que teve alguma coisa negativa. Quando eu falo negativa eu digo que não foi nada positivo...então foi diferente.

Pesquisadora: ...É engraçado isso porque eu acho que a visão que vocês tiveram de dentro dessa experiência foi tão diferente da minha que tava de fora [...] Eu acho que o diálogo que vocês conseguiram no mapa falado, que foi o mais difícil, foi de uma riqueza de informação pra pesquisa que vocês não fazem ideia [Insistindo em um retorno de Estela sobre o assunto.]

Estela: [Me olha por um bom tempo mas não comenta nada.]

Pesquisadora: E o que você achou então da análise das informações?

[Estela descreve minuciosamente o processo de construção do relatório juntamente com Mika, citando serem as duas pessoas responsáveis, pontuais e perfeccionistas.]

Neste diálogo, Estela nos parece claramente mais à vontade para conversar sobre as tarefas de realização do relatório de análise do DRP e de apresentação no Fórum. Em contraposição, sua resistência a falar da experiência do DRP remete à sua autoavaliação negativa e à sua dificuldade de lidar com críticas, o que nos consiste mais um indicador para o núcleo de sentidos subjetivos da aceitação e do reconhecimento social de seu desempenho.

Ainda com relação a maior facilidade em atuar em contextos com regras definidas, claras, às quais sabe se programar para responder às exigências e corresponder às expectativas, apontamos o seguinte trecho de informação no comentário de Estela sobre a atividade de análise das informações do DRP e a elaboração do relatório:

É porque, eu e Mika, a gente sempre trabalha junto, desde quando eu entrei na escola, desde quando a gente se conheceu a gente sempre trabalha junto. Aí, eu e ela [...] a gente sempre tem os papéis estabelecidos [...] a gente sempre tem as tarefas que a gente faz e mostra uma pra outra e vê a opinião. E foi do mesmo jeito. [...] Porque uma coisa, Graças a Deus, [...] que gente tem em comum é a responsabilidade. Ela me passa uma coisa, eu passo pra ela e a gente vai cruzando informações e a gente é super pontual e super perfeccionista, tanto eu como ela. Então acabou que o nosso relatório a gente deu o nosso melhor mesmo. Foi elogiado e tal, mas a gente deu o nosso melhor.

Interpretamos aqui que a ênfase na parceria com Mika, que sempre deu certo na escola e, foi igualmente produtiva no contexto não-formal, associa-se, em nossas análises, a uma produção subjetiva perpassada por sentidos subjetivos que se relacionam à necessidade de atender às demandas e de ser bem avaliada por todos os envolvidos no Projeto. Como expressão dessa produção subjetiva, consideramos que Estela assume, no 
contexto do Projeto, uma postura própria do contexto escolar, predominantemente orientada a responder positivamente às demandas, tendo em vista a avaliação do Outro.

Acreditamos que processos subjetivos em Estela, relacionados à necessidade de atender às demandas e ser bem avaliada, não ocorrem sem uma autorreflexão e autocrítica em um diálogo tenso consigo mesma. No completamento de frases (APÊNDICE D), Estela aponta:

8. Sofro por viver num mundo onde tudo tem uma placa para dizer o que você é/ deixa de ser.

13. Estou melhor quando estou livre.

71. Quando estou só faço o que der vontade.

76. Meus colegas são superdivertidos.

Interpretamos, nessas frases, que sentidos subjetivos relacionados à autoavaliação e à necessidade de corresponder às expectativas sociais são perpassados por sentimentos contraditórios de contentamento/descontentamento, conforto/desconforto consigo mesma, que se alternam em um permanente interjogo nos espaços sociais em que atua. Estas contradições terão um papel central em suas aprendizagens no contexto não-formal, como aprofundaremos na seção a seguir.

Por fim, embora reconheçamos em Estela uma aluna altamente reflexiva e inteligente, consideramos que este núcleo de sentidos subjetivos, que se integra tanto à configuração subjetiva da ação do aprender no contexto não-formal, quanto à configuração subjetiva da ação do aprender na escola, contribui para desfavorecer uma postura autônoma e crítica e, dessa forma, desfavorecer níveis de criatividade em sua aprendizagem, tendo em vista nossa opção teórica.

\section{(4) A relação com a avó e com a família}

Conforme já apontado, Estela tem uma relação muito próxima a sua família. Em especial, a relação com a avó, já falecida. Na entrevista semiestruturada I, ao ser convidada a citar pessoas significantes em sua vida, Estela cita "vó, mãe, padastro, vô, ..." colocando-a como primeira referência. Em várias de nossas interações, Estela cita a importância de sua avó para sua escolha profissional. Em uma delas, ao ser perguntada sobre haver gostado de realizar uma experiência de pesquisa qualitativa, como a do Projeto, Estela responde: 
Eu sempre prometi para mim...a minha avó tinha hipertensão e diabetes e a nossa família nunca teve condição de pagar hospital particular e eu vi a minha avó sofrendo com aquele atendimento horrível de postinho de saúde, de hospital. E eu via que ela sofria muito e mesmo sofrendo muito ela cuidava de uma igreja enorme, então, assim, de cada pessoa individual. Ela era uma mulher Bombril, assim, mil e uma utilidades e eu sempre admirei muito ela [...] Aí eu peguei um dia e falei pra ela que eu queria ser médica porque eu iria descobrir a cura da doença dela e ela nunca mais ia sofrer. $[\ldots]$

(Entrevista semiestruturada IV-APÊNDICE F)

Interpretamos, neste trecho de informação, que Estela tem em sua avó uma referência pessoal para valores relacionados à importância da ajuda ao próximo, à correção moral, à perseverança, à força de vida, à resiliência, entre outros. Chama-nos atenção, ainda, que a menção à avó tenha surgido em um contexto de uma pergunta sobre sua experiência no Projeto, a princípio sem nenhuma correlação direta. Em nossas construções, essas informações nos consistem um indicador de que sentidos subjetivos da relação com a avó são produzidos por Estela em diversos momentos e experiências em sua vida, constituindo-se como uma configuração subjetiva de sua personalidade que participa como núcleo de sentidos subjetivos da configuração subjetiva da ação do aprender no contexto do Projeto.

Estela é muito unida ao seu grupo familiar, constituído por sua mãe, seu pai e seu irmão. Em nossas análises, seu grupo familiar confere a ela expectativas diversas relacionadas ao sucesso nos estudos, ao sucesso profissional, à atitude exemplar, entre outras. Apontamos para essa interpretação, os trechos da carta de apresentação de Estela, escrita por sua mãe, na página de abertura do Portfólio do Projeto:

[...] Durante sua infância, teve de enfrentar a tão cruel septsemia (uma infecção na corrente sanguínea), a asma e a anemia. Mesmo tendo sua saúde limitada, Estela sempre foi muito feliz, forte e determinada.

[...] Inteligente e esforçada, ela dá o máximo de si em tudo o que faz, principalmente nos estudos. Sempre sonha muito alto e luta com bravura até o fim.

[...] Estuda a Lingua Francesa desde os dez anos de idade e graças à sua fé e determinação, passou em primeiro lugar no concurso de redação em francês e ganhou uma viagem à Mônaco em 21012.

Ela é o orgulho da família [...] um exemplo de aluna e uma excelente pessoa. [...] 
Nos trechos destacados na carta, chama-nos atenção dois aspectos. Em primeiro, a importância que a mãe confere aos valores de determinação, de esforço, de responsabilidade e de correção moral, fator que pode ser influenciado pela condição de ser a filha mais velha e a menina da família. Em segundo, o valor que a mãe confere à educação formal, ao estudo e ao reconhecimento social do esforço e da determinação de Estela, que depreendemos da sua menção ao estudo da língua francesa e da viagem à Mônaco como prêmio do concurso de redação.

Com efeito, em conversa informal com os pais de Estela, por ocasião de uma visita deles à escola, ambos nos manifestaram, em frente à Estela, a satisfação e o orgulho com o histórico-escolar da filha, com seu interesse pela língua e cultura francesa, e com sua participação no Projeto da Instituição $F$.

Consideramos que Estela assume para si este conjunto de valores e expectativas que se constituem, em sua subjetividade individual, como expressão de sentidos subjetivos da relação com a família. Este conjunto de informações nos permite um indicador para a construção da relação com a vó e a família como uma configuração subjetiva que perpassa diversos contextos da vida de Estela e se integra, como núcleo de sentidos subjetivos, a sua configuração subjetiva da ação do aprender no Projeto.

Elaboramos ainda que sentidos subjetivos do núcleo de subjetivação de necessidade de aceitação social e do reconhecimento social de seu desempenho, conforme analisado no item anterior, associados à vontade de corresponder às expectativas, perpassam igualmente este núcleo, integrando sentidos subjetivos contraditórios associados à busca por independência e autonomia e a sentimentos de contentamento/descontentamento, conforto/desconforto consigo mesma.

\section{(5) A relação com a aprendizagem como processo obrigatório}

Em nossas elaborações, Estela desenvolve uma relação singular com processos de aprendizagem. No completamento de frases (APÊNDICE D), Estela coloca:

39. Tem conteúdo que aprendo pouco porque não consigo entender.

50. Esforço-me para aprender cada vez mais.

59. Aprender é assimilar.

68. O saber tem "sabor" quando posso passá-lo adiante. 
Nas frases 39 e 50, ao expressar que não aprende porque não consegue ou que esforça-se para aprender, interpretamos em Estela sentidos subjetivos relacionados à obrigatoriedade da aprendizagem escolar, que perpassam sua relação com processos de aprendizagem de formas consciente e inconsciente. Interpretamos ainda, nas frases 59 e 68, o predomínio da representação da aprendizagem enquanto processo de assimilação passiva e reprodutiva do conhecimento. Aprender é "assimilar para a vida" e "passar adiante"; e não um processo de descobertas, de desenvolvimento de ideias novas, de posicionamentos autônomos frente aos conteúdos.

Ainda frente à pergunta "o que é aprendizagem para você?” (Entrevista semiestruturada III - APÊNDICE E), Estela responde:

Existem muitos conteúdos que eu tive na escola que eu de fato aprendi. [...] (Aprender é) Absorver para a vida toda.

Novamente, aqui, consideramos que Estela associa a aprendizagem diretamente à aprendizagem escolar e à reprodução exata do que lhe é ensinado; o que nos permite interpretar que, para Estela, o processo de aprender relaciona-se a um processo caracterizado mais pela apreensão ou assimilação de um conhecimento do que por sua apropriação crítica ou construção.

Em nossas análises, essas informações nos permitem a construção de um indicador de que a relação de Estela com processos de aprender é marcada por sentidos subjetivos relacionados à obrigatoriedade e à busca por aceitação e o reconhecimento social, em detrimento de um processo autônomo, espontâneo e de satisfação pessoal.

Consideramos ainda que a representação dos processos de aprender em Estela favorece sua tendência para instrumentalizar suas aprendizagens. Em um dos encontros do Projeto, ao ser perguntada sobre o porquê de ir para a escola, Estela responde "Para entrar na faculdade". A orientação predominantemente descritiva dos conteúdos curriculares nos cadernos de Estela nos permite ainda essa elaboração. A maior parte dos conteúdos no caderno escolar de Estela era anotada em forma de lista itemizada de tópicos, como estratégia de memorização para provas, mesmo em perguntas discursivas, como reproduzimos no exemplo abaixo: 
Atividade) Comente a marcha sobre Roma:

- Ocorreu em 28 de outubro de 1922;

- Mussolini e os outros fascistas reivindicavam sobre seus poderes e participação no governo.

- O rei escolheu Mussolini para ser $1^{\circ}$ ministro e com isso os facistas chegaram ao poder.

A importância que Estela confere a estratégias de memorização de conteúdo se expressa ainda no seguinte relato de Estela sobre seus processos de aprendizagem escolar, em especial dos conteúdo das disciplinas de História, Sociologia, e Filosofia.

Não memorizo. Nunca faço [isso]. Eu leio, quando eu leio eu absorvo. Eu fiz teatro e para memorizar minhas falas eu sabia o que os outros iriam falar [...] (Entrevista semiestruturada III - APÊNDICE E).

Consideramos que, muito embora Estela negue sua intenção em memorizar conteúdos, sua busca pela compreensão do contexto consiste precisamente sua estratégia para memorização. Aqui, mais uma vez, a importância, para Estela, de memorizar e reproduzir conteúdos de aprendizagem nos consiste uma expressão de sentidos subjetivos relacionados à necessidade e à obrigatoriedade dos processos de aprender.

Com efeito, o conjunto de informações construído nos permite a construção de um indicador da relação com a aprendizagem como um processo obrigatório como um núcleo de sentidos subjetivos que, como constituinte da configuração subjetiva da ação do aprender em Estela no Projeto, não promovia sua motivação para aprender nesse contexto. Com efeito, interpretamos que este núcleo se articulava, de forma particular, ao núcleo de subjetivação de seus sonhos e projetos futuros, marcado pela associação do ensino médio como estágio de preparação para o vestibular e o, subsequente, ingresso na universidade.

Para finalizar esta seção, e sistematizar nossas construções interpretativas sobre os elementos da configuração subjetiva da ação do aprender em Estela, no contexto do Projeto, hipotetizamos que os aprendizados no Projeto se constituíram em meio a uma produção subjetiva que, tendo em vista as articulações entre sentidos subjetivos que se expressavam nos núcleos de subjetivação da relação com os sonhos e projetos futuros, da necessidade de aceitação e do reconhecimento social de seu desempenho, favorecia uma postura predominantemente orientada ao atendimento às demandas e à avaliação; 
reproduzindo processos subjetivos similares a processos produzidos no contexto escolar. Ao mesmo tempo, essa produção subjetiva era igualmente marcada por sentidos subjetivos contraditórios que se expressavam na relação com o clima comunicacional e relacional do grupo como elemento da subjetividade social do Projeto na subjetividade individual de Estela, associados à surpresa com o novo e ao desafio pessoal, e à busca por maior liberdade e autonomia. Aprofundaremos essa análise na seção a seguir.

\subsubsection{Características da Aprendizagem de Estela no contexto não-formal}

$\mathrm{Na}$ seção anterior, apresentamos nossas análises interpretativas sobre elementos da subjetividade de Estela que constituíam sua configuração subjetiva da ação do aprender no contexto não-formal. No decorrer do Projeto e de nossas interações, muito embora reconheçamos em Estela diversos momentos de grande reflexividade em suas aprendizagens, consideramos que sua produção subjetiva favorecia, no Projeto, uma postura predominantemente orientada ao atendimento às demandas e à avaliação. Formulamos, assim, a predominância das aprendizagens, eminentemente, reprodutiva e compreensiva, em oposição à aprendizagem criativa, orientada à problematização, à transcendência e à produção de ideias novas (MITJÁNS MARTÍNEZ, 2012).

Não obstante, identificamos momentos de aprendizagem criativa precisamente em suas reflexões sobre a sua própria experiência de aprendizagem no Projeto e a concepção de ciência. Argumentaremos essa análise interpretativa com base em nossas elaborações sobre as experiências de Estela em processos de personalização da informação e de personalização da experiência da aprendizagem.

\subsubsection{A personalização da informação}

Em nossas análises do diário de bordo de Estela, chama-nos atenção a frequente reprodução literal de informações apresentadas nos encontros. Com efeito, de forma similar ao caderno escolar, o diário de bordo é predominantemente descritivo, marcado por listas cronológicas ou itemizadas sobre os conceitos abordados e por poucas anotações pessoais.

A forma como Estela respondia às atividades do Projeto demonstrava, igualmente, sua atenção primeira a atender à demanda respondendo o que julgava ser o tido como 
correto, em oposição a sua própria construção sobre o tema. Repetimos a menção ao seguinte trecho da Entrevista Semiestruturada IV (APÊNDICE F), por nos consistir ilustrativo para esta consideração.

É porque eu e Mika a gente sempre trabalha junto, desde quando eu entrei na escola, desde quando a gente se conheceu a gente sempre trabalha junto. [...] Porque uma coisa, Graças a Deus, [...] que gente tem em comum é a responsabilidade. [...] a gente é super pontual e super perfeccionista, tanto eu como ela. Então acabou que o nosso relatório a gente deu o nosso melhor mesmo. Foi elogiado e tal, mas a gente deu o nosso melhor.

Por essas informações, consideramos que as aprendizagens de Estela, no contexto do Projeto, eram caracterizadas por uma predominante orientação para a compreensão dos conteúdos abordados, tendo em vista sua permanente preocupação em demonstrar sua aprendizagem dos conteúdos como se fosse obter avaliação por tal. A dificuldade de Estela de compreender o conceito ampliado de saúde, central no Projeto, nos consiste outro indicador para essa interpretação. Em uma ordem cronológica, observamos seu entendimento deste conceito a partir das seguintes informações:

- Em encontro, do módulo II, Saúde e Educação, em novembro de 2012, Estela reproduz em seu diário de bordo, em forma de lista descritiva, informações sobre o conceito de saúde (ANEXO V).

- No ensaio de apresentação do Fórum, em agosto de 2013, Estela inicia a apresentação do Projeto relatando sua percepção sobre "Saúde" antes e depois do Projeto. No slide do Powerpoint, aponta:

\section{O que é saúde?}

\begin{tabular}{lll}
\multicolumn{1}{c}{ Antes } & $\mathbf{X}$ & \multicolumn{1}{c}{ Depois } \\
Ausência de & & $\begin{array}{l}\text { Tudo, pois saúde é mais que um } \\
\text { enfermidade }\end{array}$ \\
Bem estar geral & &
\end{tabular}

A apresentação desta tela, foi acompanhada do seguinte diálogo entre Estela e o monitor:

Estela: Antes eu achava que saúde era só remédio, médico; ...era relacionada somente à ausência de enfermidade. Mas depois, eu vi que saúde é muito mais que isso, saúde é tudo,... assim.

Monitor: [...] Acho que a gente podia elaborar um pouco mais o conceito de saúde. [...] Porque é complicado dizer que é "tudo". O que mais você podia falar?

Estela: É que assim...é muito complexo. Saúde é tudo na vida. [começa a rir e não consegue responder deixando para o grupo completar a ideia] 
Ao associar o conceito de saúde a uma vivência, compreendemos que Estela demonstra uma compreensão diferenciada do senso comum. Não obstante, ao ser convidada a explicar melhor sua compreensão, Estela não consegue argumentar, demonstrando uma falta de elaboração própria sobre o tema.

- A ausência de referência ao conceito no instrumento da Redação (APÊNDICE G), realizado em dezembro de 2013, três meses após o término do Projeto, também nos indica a pouca elaboração de Estela sobre o conceito. Em sua argumentação sobre a temática do Programa Mais Médicos, muito embora seja solicitada a buscar a correlação com aprendizados do Projeto, Estela não cita a ideia de uma compreensão ampliada de saúde.

Pelos eventos ressaltados, consideramos que Estela, ainda que tenha compreendido a ideia deste conceito, não chegou a desenvolver uma reflexão própria e implicada sobre ele. Em nossa interpretação, Estela não chegou a personaliza-lo.

\subsubsection{A personalização da experiência de aprendizagem}

Em oposição a sua predominante orientação, no Projeto, para a aprendizagem reprodutiva e compreensiva, consideramos, em nossas análises, que houve a expressão da criatividade na aprendizagem em Estela, associada às formas com as quais ela personalizou sua experiência de aprender no Projeto.

Conforme já apontado na seção anterior, a aplicação do DRP na escola consistiu para Estela um grande desafio em seu papel como mediadora. Conforme citado, Estela demonstrou diversas dificuldades na tarefa da mediação. Em nossas observações, durante o DRP, Estela mostrava-se nervosa e olhava com frequência para os monitores de forma a comprovar as instruções que apresentava. No decorrer dos debates, Estela tinha dificuldades em encontrar o equilíbrio entre incentivar e controlar as participações. Em vários momentos em que poucos estavam à vontade para participar, Estela não fazia perguntas instigantes. Ao mesmo tempo, em momentos quando todos pareciam se animar, comentar assuntos e pedir papéis para registro, Estela pedia calma e silêncio. Neste seu movimento, compreendemos seu predominante medo do descontrole da turma e desorganização do grupo, ainda que a fluidez mais livre do diálogo fosse importante para 
o sucesso da dinâmica. Ao dar orientações, Estela não improvisava suas falas para possibilitar uma melhor compreensão dos participantes. Havia memorizado as instruções da dinâmica e, ao não ser compreendida, apenas repetia as mesmas frases. Por diversas vezes, Estela não ofereceu o tempo necessário para a reflexão e manifestação dos participantes; sua atenção e preocupação pareciam residir principalmente no que seria a sua própria próxima fala. Nesse sentido, em vários momentos, Estela não considerou importantes contribuições que surgiam do grupo, como forma de alimentar o diálogo e instigar informações relevantes.

Com efeito, conforme já apontado, consideramos que o enorme desafio da tarefa de aplicação do DRP para Estela se constituiu em meio a uma produção subjetiva que integrava, entre outros elementos, o núcleo subjetivo de aceitação e reconhecimento social cujos sentidos subjetivos não favoreciam sua capacidade de improviso e exposição pessoal.

No entanto, cabe ressaltar que, se Estela encontrou enorme dificuldade em sua atuação como mediadora, ela, por outro lado, e talvez precisamente pelo desafio vivido, apresentou uma reflexão altamente criativa sobre sua experiência com o Projeto em sua aprendizagens sobre ciência e o fazer científico.

Na entrevista semiestruturada IV (APÊNDICE F), ao falar sobre sua experiência com diferentes métodos de pesquisa, Estela comenta:

Estela: $\quad[\ldots]$ Eu já tinha feito uma pesquisa com as normas da ABNT, mas era quantitativa. Era uma pesquisa que o professor deu determinados assuntos e deu vinte questionários para cada aluno e separou a sala em dois. Aí, todo mundo tinha vinte questionários e cada questionário era meio que um livrinho assim. E eu tive que preencher com um monte de gente da nossa cidade e tal. E depois a gente teve que calcular, colocar em tabelas aquela coisa toda e apresentar no final do ano como trabalho final. Assim, foi super legal.

Pesquisadora: É um outro tipo de pesquisa também. Muito interessante e importante [...]

Estela: E mais fácil! Porque você lidar com número; número é número. Tá ali. Errou refaz. Agora quando você tá fazendo pesquisas com o público em que cada um tem uma bagagem você tem que ter um cuidado de como você vai fazer a pergunta e como a pessoa vai interpretar... E depois a gente tem que analisar a carga [bagagem histórica] da pessoa pra entender o porquê da resposta. É mais complexo. [...]

Pesquisadora: Você gostou de fazer esse tipo de pesquisa? 
Estela: Eu amei fazer isso, superlegal. [...] Eu sempre tento descobrir alguma coisa nova e com a pesquisa, essa pesquisa aqui, eu senti que eu posso descobrir alguma coisa nova, que não é só cientista que estudou a vida toda que pode descobrir.

Pesquisadora: E o que você citaria, dessa pesquisa, que você trouxe de novo?

Estela: [Após pensar um tempo.] Eu sempre vejo cada indivíduo na sociedade... Sempre foi me apresentado isso na minha vida acadêmica que nós somos um número na sociedade e eu nunca discordei...Porque a gente tem CPF e coisa assim e a gente de fato é um número. Só que eu descobri também e eu percebi muito isso na minha pesquisa aqui...Eu vou colocar um metáfora, eu espero que você entenda...que nessa pesquisa eu vi que para cada número existe infinitos números até chegar em outro. Então cada número tem infinitos pensamentos, infinitas bagagens e experiências até chegar no outro e você só transmite pro outro o que o outro te permite e quando a gente, quando eu tive que me esvaziar tudo o que eu sabia [...] pra permitir que o meu público alvo me desse as informações, e não eu dasse. Foi uma experiência incrível era como se eu um número da sociedade tivesse que apagar todos os meus infinitos pontinhos e permitisse que os outros números me preenchessem com seus pontinhos. E isso foi novo pra mim. Porque por mais que eu goste de ouvir as pessoas, por mais que eu goste de trocar informações com as pessoas, é super diferente você anular tudo o que você já aprendeu até aquele momento e deixar que os outros façam. Isso foi novo! [...] Eu nunca tinha feito.

Interpretamos, neste trecho, que a experiência de mediar um debate, como uma situação em que não é preciso mostrar ou provar conhecimento, ao que ela refere como "se anular", constitui uma experiência nova e surpreendente para Estela, substancialmente diferenciada das experiências da escola onde "provar que se sabe" é a regra. Consideramos que esta reflexão se singulariza, em Estela, em meio a sua produção subjetiva relacionada à necessidade de aceitação e reconhecimento social, a qual confere a Estela sua orientação a corresponder às demandas e a ser bem avaliada, articulada a sua produção subjetiva de autocrítica e busca por independência e autonomia.

Para além da atividade do DRP, as reflexões de Estela sobre sua experiência no Projeto como um todo, consistiram reflexões e aprendizagens sobre si. As frequentes autorreflexões de Estela em diversos momentos posteriores à experiência do Projeto nos consistem indicadores para essa construção. No instrumento da entrevista semiestruturada IV (APÊNDICE F), Estela comenta: "Tive tanto contato com tanta diversidade será que a minha cultura está certa?". No encontro de avaliação do DRP, Estela pondera: "Aprendi que eu tenho que brincar mais". Em outro momento deste mesmo instrumento, expressa: 
Gostei muito de apresentar [no Fórum]. Mas aprendi muito mais na questão de como passar. [...] Quando passar, se preocupar em como. Por mais que você tenha uma verdade comprovada, essa verdade vai sempre ser questionada.

Ou ainda, conforme o já citado trecho da entrevista semiestruturada IV (APÊNDICE F), "É super diferente você anular tudo o que você já aprendeu até aquele momento e deixar que os outros façam" e [...] "Superei meus limites".

No processo de reflexão sobre suas experiências no DRP e no Projeto, Estela vai desenvolvendo para si, como expressão de sua produção subjetiva singular, uma nova e personalizada representação sobre a ciência que, a exemplo de Camile, a inclui ativamente como pesquisadora, com ênfases à necessidade de abertura pessoal e à capacidade de ouvir e de interpretar "verdades que vão sempre ser questionadas".

Nesse processo, interpretamos alguns dos processos constitutivos da aprendizagem criativa já apontados pela literatura da área. Em primeiro, o exercício da condição de sujeito, expresso não apenas na intencionalidade reflexiva sobre o tema, mas na autocrítica e na busca por uma reorientação de si mesma frente a expectativas sociais. Em segundo, a geração de sentidos subjetivos que recursivamente alimentam o próprio processo do aprender. Ressaltamos, em Estela, que sentidos subjetivos produzidos perante um momento inicial de decepção se convertem em ações autorreflexivas que desencadeiam na personalização da experiência de aprendizagem e na problematização da temática sobre o fazer científico; o que gera em Estela caminhos para uma nova representação da ciência e de seu fazer.

Ressaltamos, o quanto essa reflexão em Estela emerge como uma expressão da configuração subjetiva da ação do aprender, marcada tanto pela produção subjetiva associada ação na aplicação do DRP, quanto por sentidos subjetivos relacionados aos núcleos de sentidos subjetivos da necessidade de aceitação e do reconhecimento social de seu desempenho. Pontuamos, por fim, que a aprendizagem criativa emerge em diferentes níveis e que embora Estela não tenha, em nossas análises, apresentado momentos de criatividade na aprendizagem, consideramos que esta sua reflexão sobre a ciência e o fazer científico emerge como um momento de criatividade na aprendizagem. 


\subsection{A participante Mika}

\subsubsection{A caracterização de Mika e a expressão da subjetividade social do contexto formal em sua subjetividade individual}

Com base em nossas interações, percebemos em Mika uma pessoa doce, sensível ao outro, sociável e interessada. Chama-nos atenção que Mika, em suas relações conosco e com colegas, utiliza-se com frequência da brincadeira e da gaiatice como forma de aproximação, de quebra de formalidades e de climas tensos.

Mika nasceu e sempre morou na mesma cidade do entorno de Brasília, em uma região reconhecida por problemas de pobreza e violência.

Ela mora com o pai, a mãe e o irmão; sendo muito unida ao seu grupo familiar. Seu pai trabalha como guarda na Instituição F. Com frequência o encontrávamos e tínhamos a oportunidade de notar a interação alegre e brincalhona entre os dois, assim como o indisfarçável orgulho que o pai tinha da filha ser uma bolsista de pesquisa na instituição de seu trabalho.

Por ser sociável, Mika estava sempre rodeada de colegas tanto na escola, quanto no Projeto. Em nossas observações, víamos Mika interagir com enorme facilidade tanto com meninas, como com meninos, com adultos e crianças.

No momento da pesquisa Mika realizava o $3^{\circ}$ ano do ensino médio e expressava muitas dúvidas sobre a escolha do curso superior. Expressava que vários colegas a sugeriam comunicação e jornalismo, por sua enorme facilidade no trato com o outro. Mika, no entanto, preferia expressamente disciplinas, como química e biologia, que envolviam aulas práticas e ativas, em contraposição às disciplinas de sociologia, filosofia e história, que achava muito teóricas. Em suas palavras, em um dos encontros do Projeto, comenta que mudaria a escola com "aulas mais dinâmicas; as aulas são muito cansativas". Na entrevista semiestruturada II (APÊNDICE C), aponta "Não gosto das aulas de teoria". Por fim, relata ainda:

Não gosto de filosofia e história. Não consigo entender; falam sobre filósofos e ideais. Eu até entendo quando o professor explica mas depois não sei mais [...] não entendo como vou usar isso. (Na entrevista semiestruturada III - APÊNDICE E) 
Ao final da pesquisa, passou no vestibular para uma universidade federal para o curso de Farmácia.

Mika tem histórico escolar excelente, com notas altíssimas. Estuda na mesma escola de Estela, de quem é grande amiga e com quem compartilha grupos de estudos e trabalhos. Em contraposição à Estela, que se apresenta mais tímida, Mika tem enorme facilidade de lidar com grupos diversos, sendo muito popular e querida por todos, tanto no contexto não-formal, quanto no contexto escolar. No Projeto, era considerada a mascote do grupo e na escola, observávamos Mika sempre rodeada de amigos nos momentos de intervalo. Em uma ocasião de uma gincana que envolvia a escola inteira, Mika era a animadora da torcida de seu time.

\subsubsection{A configuração subjetiva da ação de aprender em Mika no contexto não-formal}

De forma similar às análises dos casos de Camile e Estela, buscaremos compreender elementos constitutivos da configuração subjetiva da ação do aprender em Mika no contexto não-formal, centrando-nos em dois aspectos, (1) elementos de sentidos subjetivos relacionados à expressão da subjetividade social do contexto do Projeto na subjetividade individual de Mika; e (2) núcleos de sentidos subjetivos organizados na trajetória de vida e no momento atual de Mika.

\subsubsection{Elementos de sentidos subjetivos relacionados à subjetividade social do contexto não-formal}

Retomamos, aqui, os elementos da subjetividade social do grupo do Projeto, apresentados nos casos de Camile e Estela, que se expressam: na consideração pelo Projeto como espaço privilegiado e no clima relacional e comunicacional do grupo. No caso de Mika, apresentamos ainda outro elemento da subjetividade social do grupo que, em nossas considerações, não se constituiu nem em Camile, nem em Estela: a expectativa da aplicação do DRP na escola e da apresentação no Fórum como desafios a transpor. Acreditamos que esses elementos da subjetividade social expressavam-se de forma singular na subjetividade individual de Mika, em complexa articulação com outros elementos subjetivos produzidos por ela no contexto não-formal. 
Com relação à consideração pelo projeto como espaço privilegiado, consideramos que a participação no Projeto como bolsista na Instituição $F$. adquire um valor particular em Mika. Na entrevista semiestruturada IV (APÊNDICE F), ao ser perguntada sobre o motivo, as expectativas e a significação para si da participação no Projeto, Mika nos responde:

Não sabia [do Projeto]. A. [a coordenadora da escola] chamou os melhores alunos. Me lembrei que meu pai trabalhava lá; queria um estágio; queria ser médica na época. [...] Queria provar para mim mesma se conseguia um estágio.

Interpretamos, em sua resposta, que a consideração pelo Projeto como uma oportunidade privilegiada se expressa na subjetividade individual de Mika, por meio de sentidos subjetivos relacionados a vários aspectos de sua vida pessoal entre eles a sua autoconfiança como boa aluna na escola e sua merecida indicação para o Projeto, a sua relação com a família; e, por fim, e principalmente, a relação com seu momento de vida marcado pelo fim do ensino médio, pela necessidade de refletir seu futuro profissional e pela oportunidade em se desafiar em uma experiência de trabalho. Assumimos que, sob esses sentidos subjetivos, este elemento da subjetividade social se expressava na subjetividade individual de Mika, colaborando para seu prazer e sua motivação na participação no Projeto.

Com relação ao clima relacional e comunicacional do grupo, consideramos que este elemento da subjetividade social se expressa na subjetividade individual de Mika por meio de sentidos subjetivos associados à relação com o grupo, com os monitores do Projeto e com o fazer pedagógico. Com relação a sentidos subjetivos associados à relação com o grupo e com os monitores, acreditamos que, pela sociabilidade de Mika, desenvolveu-se entre ela e o grupo do Projeto uma relação especial. Entre os nove alunos bolsistas, Mika era tomada como a mascote do grupo; no transporte da van, com frequência, cantorias e brincadeiras alegravam o grupo e Mika sempre estava no centro. Em um dos encontros do Projeto, no intervalo, todos se juntaram para fazer música, e um monitor fez uma improvisação de "rap", em estilo de batalha. Neste estilo, o objetivo é “desmontar" o adversário, criticando-o e xingando-o. O monitor escolheu Mika para improvisar a letra da música, falando mal de sua roupa, de seu bairro, de sua aparência. Todos riram muito. No grupo, Mika era a única a quem esse tipo de brincadeira poderia ser realizado, em razão de seu jeito aberto e brincalhão. 
Com relação ao fazer pedagógico, consideramos que ele surpreende Mika pela mudança constante das equipes, dos espaços físicos utilizados e pela orientação prática. Como citado, Mika tem expressa preferência por aulas práticas e dinâmicas e o fazer pedagógico no Projeto lhe era particularmente prazeroso nesse sentido. Na entrevista semiestruturada IV, ao ser perguntada sobre momentos de aprendizagem significativos no Projeto, Mika cita: o vídeo sobre a Revolta da Vacina, no Módulo II; e a visita ao Congresso Nacional onde teve a oportunidade de ver e ouvir pronunciamentos de senadores. Na avaliação de Mika, "Era irônico. Eles falam, falam mas cadê a prática?”. Nesta mesma entrevista, Mika comenta ainda "A cada módulo eram pessoas diferentes. E eles sabiam como passar." Cita ainda que o módulo que mais gostou foi o Módulo V Comunicação e Mobilização, por haverem aprendido "enquanto realmente a gente fazia uma coisa", referindo-se ao vídeo que produziram sobre o PSE.

Em nossas interpretações, esse conjunto de informações nos permite elaborar que a orientação prática do fazer pedagógico do Projeto, caracterizado por aprendizagens práticas, sem rotinas e com o envolvimento de muitas pessoas diferentes se integrava a processos subjetivos em Mika, associando-se à motivação para o engajamento e a sentimentos de prazer, de autoconfiança e de autonomia.

Ainda com relação sentidos subjetivos associados ao fazer pedagógico, na entrevista estruturada IV (APÊNDICE F), ao ser perguntada sobre como percebia a diferença entre aprender na escola e no Projeto, Mika responde:

[...] Pode falar, não se tem medo de colocar sua opinião. [Eles nos perguntavam] "Ah, e aí, como é lá com vocês?" Eles são ótimos mediadores... Isso melhorou muito... Nem tanto o conteúdo, mas mesmo sem muito conhecimento é importante falar.

Neste relato, consideramos que Mika era sensível ao clima de abertura e de confiança que se estabelecia nos encontros do grupo; onde ela se sentia à vontade para falar "mesmo sem muito conhecimento". Indiretamente, interpretamos, nessa informação, o valor que Mika confere à avaliação presente no contexto escolar e como a forma com que Mika o subjetiva influencia sua postura como aluna.

Ainda em outro momento da entrevista, Mika estabelece novamente uma comparação entre a aprendizagem no Projeto e a aprendizagem escolar: 
De todos os módulos, esse foi o que eu mais gostei das pessoas que tavam aplicando. [Na escola] a quantidade é muito grande de alunos, tem que ter autoridade; é muito pouco tempo e muito aluno e conteúdo; não dá pra brincar. (APÊNDICE F)

Interpretamos, neste relato de Mika que aspectos do contexto escolar, tais como a autoridade do professor, a pouca interação entre alunos, a falta de tempo, a quantidade de conteúdos e a obrigatoriedade da aprendizagem, tornam-se elementos de sentidos subjetivos em Mika no contexto não-formal, na comparação destes com aspectos deste contexto tais como a ausência da autoridade do professor, o tempo para interações, a possibilidade para livre expressão e as "brincadeiras".

Com base nessas informações, construímos um indicador do clima de comunicacional e relacional do grupo como elemento de sentido em Mika. Consideramos ainda que este elemento se expressava na subjetividade de Mika de forma a favorecer sua postura de implicação, de interesse, de abertura para a aprendizagem, de prazer e de autoconfiança nas situações de aprendizagem no contexto não-formal.

Por fim, consideramos um novo elemento da subjetividade social do grupo relacionado às expectativas da aplicação do DRP na escola e da apresentação no Fórum como desafios a transpor. Em nossas construções interpretativas, o desafio frente às tarefas de aplicação do Diagnóstico Rápido Participativo (DRP) na escola e de apresentação final no Fórum, consistiu em si um elemento de sentidos subjetivos compartilhado pelo grupo e associado à autoconfiança, ao compromisso, e à coesão do grupo. Cabe ressaltar que, a aplicação do DRP, exigia a atividade de mediar debates, sobre as concepções de saúde e as condições relacionadas ao bem estar na localidade, entre representantes de grupos da comunidade escolar, diretores, coordenadores pedagógicos, alunos, professores e funcionários de limpeza da escola.

Trechos do diálogo citado na página 94 nos permitem compreender a grande tensão gerada pela expectativa da atividade do DRP. Entre eles,

"É porque o povo é muito crítico na minha escola. Eles não vão entender $[\ldots] "$;

"Vamos sofrer discriminação por sermos alunos da escola e fazer um trabalho com outros alunos";

"Não tem que ensinar nada, né?";

"Vou começar a gaguejar" 
Em nossas observações, nos três últimos encontros anteriores à realização do DRP, percebemos um crescente clima de apreensão, todos estavam tensos e ansiosos para as aplicações, o que se traduzia em constantes chacotas sobre possibilidades de tudo dar errado, entremeadas a expressões de insegurança e nervosismo. Não obstante, ainda que sob essa forte expectativa, percebíamos no grupo a mesma coesão e o compromisso com o Projeto, presente em todo o seu decorrer. A aplicação do DRP apresentava-se não apenas como uma tarefa individual, mas como uma atividade que dependia da atuação de todos juntos. Todos estavam engajados em uma tarefa que ninguém sabia, com clareza, se ia dar certo, inclusive os monitores. Mais do que um ambiente de aprendizagem para os participantes, a preparação para o DRP assemelhava-se à construção de uma peça teatral, dirigida pelos monitores e cujo resultado era incerto. Dessa forma, a grande tensão era suportada, ao mesmo tempo, por um grande sentimento de co-responsabilidade de todos os envolvidos, o que contribuía para fortalecer ainda mais a coesão do grupo e a relação com os monitores. Nos encontros anteriores à aplicação do DRP, ainda que a atuação dos monitores se caracterizasse, predominantemente, por constantes falas motivacionais, intercaladas por falas de exigência, o grupo e as interações do grupo eram o centro, os grandes protagonistas dos encontros. Ressaltamos que o clima relacional nesses momentos se diferenciava ainda mais da tradicional hierarquia professor-aluno da realidade escolar.

Com relação à expressão desse elemento de sentido na subjetividade individual de Camile, consideramos que ela se diferenciava do grupo, parecendo mais tranquila e confiante frente às expectativas da atividade. Apontamos, mais uma vez, suas experiências como líder do grêmio estudantil da escola e de atuação no movimento social na sua cidade como elementos de sentido de sua subjetividade individual que promoviam uma expressão subjetiva favorecedora dessa postura. Mediar debates, organizar e participar de eventos de movimentos sociais eram tarefas com as quais tinha maior experiência e familiaridade.

Por motivos diferenciados, interpretamos que esse elemento de sentido também não se expressou na subjetividade individual de Estela. Frente aos desafios de aplicação do DRP e de apresentação no Fórum, ela se mostrava confiante em realizar as tarefas por associá-las às demandas escolares e à sua experiência como aluna. Sua autoindicação como mediadora do DRP, nos dois dias de aplicação, nos consiste indicativo desta 
autoconfiança. No entanto, de forma diferenciada de Camile que se apoiava em suas experiências de mediação em suas atuações no grêmio estudantil e no movimento social, Estela se apoiava em seu histórico escolar de excelente comportamento e desempenho em provas e atividades de trabalho em grupo. Estela não tinha consciência do desafio da tarefa que a aguardava e que se revelou enormemente difícil para ela, como vimos na análise de seu caso.

Em contraposição, em Mika, este elemento da subjetividade social do grupo se expressa em sua subjetividade individual, constituindo processos subjetivos diversos relacionados à forma como Mika lida com momentos de pressão. Nas duas dinâmicas do DRP, cada bolsista revezou com sua dupla a função de mediador e relator, em cada um dos dias. A dupla de Mika foi a única que não revezou. Por solicitação de Mika, os dois dias da dinâmica foram mediados por Estela. Sua recusa em atuar como mediadora do DRP nos consiste um primeiro indicador para a construção interpretativa da expressão deste elemento da subjetividade social na subjetividade individual de Mika.

No último encontro antes do Fórum, no ensaio geral das apresentações, chamounos ainda a atenção o seguinte diálogo entre Mika e a monitora:

Monitora: Gente, eu só quero ver amanhã quando a Mika for chamada. E se ela desmaiar?

Mika: [Subindo ao palco] Não mas eu estou calma. Até eu estou me surpreendendo comigo. Acho que é porque eu ainda não tô acreditando.

[Mika se mantém bastante nervosa, trava no início e depois fala com fluência.]

Destacamos, aqui, que a relação de Mika com os momentos de pressão não passa desapercebida de seus colegas que, frente ao seu exacerbado medo, chegam a manifestar dúvidas sobre sua capacidade de conseguir realizar as tarefas demandadas. Ressaltamos, no entanto, que em sua atuação no Fórum, observamos Mika realizar sua apresentação com fluência, e aparente calma e satisfação. Mika não lia os slides, utilizava-se de uma linguagem simples e complementava sua fala com exemplos concretos mencionados em improviso. Em nossas análises, Mika, demonstrou, ao mesmo tempo, em sua atuação no Fórum, sua tendência a se intimidar e sua capacidade de lidar de forma construtiva com momentos de pressão. Aprofundaremos esse aspecto na seção a seguir.

\subsubsection{Núcleos de sentidos subjetivos organizados a partir da trajetória de vida e na ação de Mika no contexto não-formal}


Em nossas elaborações, em articulação com os elementos de sentidos subjetivos relacionados à subjetividade social do contexto não-formal, outros núcleos de sentidos subjetivos atuais e/ou organizados na trajetória de vida integravam-se à configuração subjetiva da ação do aprender em Mika no contexto não-formal. Entre eles, núcleos de sentidos que se expressam: (1) no uso da brincadeira e do humor nos espaços sóciorelacionais; (2) na relação com a aprendizagem como processo de pressão; (3) na relação com a família; e (3) na autovaloração como pessoa sociável. Analisamos, a seguir, cada um deles.

(5) O uso da brincadeira e do humor nos espaços sócio-relacionais

Conforme já apontado, a brincadeira e o humor consistem um importante aspecto das relações sociais de Mika. No completamento de frases (APÊNDICE D), ela aponta:

6. Na escola, me divirto, aprendo

20. Eu sou brincalhona, amo sorrir, viver...

23. Amo estar com a família, bagunçando

30. A felicidade o sentimento que mais me atrai

36. Gosto muito de sorrir

71. Quando estou só faço bagunça.

A frequência da referência a aspectos como "rir", "sorrir", "bagunçar", "se divertir", "brincar" nos permite interpretar sobre o valor que à presença do humor, da diversão, e da brincadeira adquire em Mika, como fonte de sentidos subjetivos que perpassam suas relações sociais. Como outro indicador para essa construção, apontamos o momento, na entrevista semiestruturada I (APÊNDICE B), em que ao ser perguntada sobre “Qual o sentido da vida para você?”, Mika responde na seguinte ordem: família, pessoas, amigos, partilhar, brincar, sorrir.

Em conversa informal sobre timidez, Mika nos expressa ainda que não se considera tímida. Rapidamente, atribui isso à relação com sua família. Segundo ela, a família inteira brinca de "pagar mico" um para o outro e o grande motivo é fazer o outro rir, sem se importar em parecer ridículo ou não. Conta-nos, então, de seu último Natal quando ela, seu irmão, seu pai e sua mãe improvisaram juntos uma peça teatral para o restante da família. "Foi muito engraçado!! Todo mundo riu muito!!" Com efeito, em nossas interações com Mika, percebemos que em diversos momentos ela brinca, seja com alguma característica da pessoa com quem fala, seja com suas próprias características de ser desligada e espontânea, como forma de gerar um clima de descontração. 
Na entrevista com os monitores do Projeto, a palavra utilizada para descrever Mika foi "transparência". Em nossa interpretação, no entanto, seu jeito alegre e informal não se refere à transparência ou espontaneidade; trata-se, ao contrário, de uma estratégia recorrente e intencional em Mika, utilizada como forma de aproximação a pessoas e conteúdos. Mika reconhece isso ao expressar que é sua forma de perder o medo e vencer a timidez.

$\mathrm{Na}$ escola, esta mesma postura é igualmente percebida em suas interações com colegas, professores e conteúdos curriculares. Como ilustrativo citamos um momento em que, em nossas observações, na sala de aula, Estela pergunta à professora de História o significado da sigla do movimento social no Brasil "MTD”. Como a professora não sabia a resposta, Mika começou a inventar possibilidades citando "Movimento dos Trabalhadores Desempregados". Todos riem muito pela piada inventada por Mika, para depois de uma consulta na Internet, pelo celular, aprenderem que esta é, de fato, a tradução correta da sigla.

Em outro momento da pesquisa, em conversa informal com Estela e Mika, as duas nos relatam o seguinte fato vivenciado na escola:

Mika: [...] É que uma vez a gente foi na sala de direção da escola, e eu olhei uma foto do diretor e disse [para o diretor] "Nossa, você tá a cara do Sidney Magal!". [As duas riem.]

Estela: Como é que você foi dizer isso?!

Mika: Mas era parecido, não é? Você também pensou, não pensou? [rindo com um tom desafiador]

Estela: Eu penso mas eu guardo pra mim!

Mika: É que eu vou falando mesmo e depois é que eu fui pensar!! [risos]

Neste relato, interpretamos que, frente à timidez de Estela, Mika sutilmente confere à sua própria característica de "não ter medo de falar algo engraçado", uma autovaloração de orgulho e coragem.

Pelo conjunto de indicadores, consideramos que o humor e a brincadeira em Mika constituem um núcleo de sentidos subjetivos associados à relação com o outro e com o desconhecido. Em nossas construções, este núcleo integra seus processos de aprendizagem nos contextos de aprendizagem formal e não-formal, relacionando-se a sentimentos de autoconfiança, de autonomia, e de abertura frente ao novo, favorecedores de processos imaginativos e de criação. Aprofundaremos essa análise na seção a seguir. 
(6) A relação com a aprendizagem como processo de pressão

Consideramos que a relação de Mika com seus próprios processos de aprender é perpassada por aspectos diversos tais como: (1) a representação da aprendizagem; (2) a percepção do papel da aprendizagem em sua vida; e (3) a sua relação com a pressão em processos de aprendizagem.

Com relação à representação da aprendizagem, ao ser perguntada "O que é aprender para você?” (Entrevista semiestruturada III - APÊNDICE E), Mika responde: "Alguém me transmite algo que ela sabe. E da forma como me passou eu consigo repassar". No mesmo instrumento, ao ser perguntada sobre como aprende, ela responde "Quando o professor explica de forma bem clara e objetiva". Por fim, ao ser perguntada sobre como se sente quando aprende, Mika relata

Dever cumprido. Antes meu maior sonho era chegar no $3^{\circ}$ ano e saber tudo sobre tudo. Chego ao final e vejo que tem muito conteúdo que não sei; que preciso aprender mais. Sinto-me satisfeita; eu consegui cumprir a meta. A pior coisa é você não aprender o que estão te ensinando...

Interpretamos, nessas informações, que a representação que Mika tem sobre o conhecimento, de forma similar à Estela, relaciona-se a um conhecimento pronto, acabado, não passível de crítica e de permanente construção. A aprendizagem, por sua vez, relaciona-se a um processo de assimilação e reprodução de conteúdos, em nossas análises, marcado em Mika por sentidos subjetivos relacionados à obrigatoriedade e à necessidade de atender às demandas sociais.

Com relação à percepção sobre o papel do aprender em sua vida, destacamos as seguintes frases no completamento de frases (APÊNDICE D):

15. Tenho certeza que sou extremamente responsável.

16. Minha principal preocupação é passar na Unb.

17. Desejo me realizar profissionalmente.

31. Considero que posso tudo, se eu for objetiva.

33. Sinto dificuldade de estudar fora do horário da aula.

38. Meus estudos é a ferramenta para meu futuro.

44. Meu maior tempo dedico a meus próprios estudos.

68. O saber tem "sabor" quando pode ser utilizado.

72. Meu maior temor ficar só ou não ser "alguém"

74. O estudo é meu melhor amigo. 
Aqui, mais uma vez, interpretamos informações que nos indicam serem os processos de aprender em Mika perpassados por sentidos subjetivos relacionados à preocupação com o sucesso no vestibular, com o ingresso no ensino superior e com a carreira profissional $(16 ; 17 ; 72) \mathrm{e}$, de forma similar à Estela, com o papel do estudo no alcance desses desejos $(38 ; 44 ; 74)$. Conforme já colocado nos casos anteriores, consideramos que esses sentidos subjetivos são expressões, na subjetividade individual de Mika, da subjetividade social relacionada ao momento do ensino médio em nossa sociedade. Consideramos ainda que esta produção subjetiva, tanto em nível individual em Mika, quanto em nível social, tende a acentuar a instrumentalização e a obrigatoriedade do estudo e da aprendizagem, em processos onde o aprender deixa de ser associado ao prazer da descoberta, da imaginação, e da reflexão espontânea e pessoal para se tornar predominantemente um processo de busca pela resposta certa para cumprir um dever e satisfazer o Outro, tomado como o sistema de avaliação da educação formal. Para essa interpretação, apontamos a contradição presente nas frases em que Mika expressa "dedico meu maior tempo aos estudos" (44) e o "estudo é meu melhor amigo" (74), e, ao mesmo tempo, às frases "sinto dificuldade de estudar fora da hora da aula" (33), "aprendo na pressão"(69), e "sou extremamente responsável”(15), sobre a própria dificuldade de lidar com o estudo sistemático.

Na entrevista semiestruturada III (APÊNDICE E), ao ser perguntada sobre como avalia seu processo de aprender, Mika responde "Mediano. Poderia me esforçar mais porque não dedico tantas horas para o estudo. Aprendo na sala e fazendo dever de casa; não estudo além”. Na mesma entrevista, Mika ao ser perguntada sobre quando se sente animada a estudar, ela responde "Gosto e não gosto de estudar. Gosto de fazer os deveres de casa." Por fim, na pergunta sobre quando se sente animada a aprender sua resposta consiste "Quando tem algum conteúdo que o professor não é interessante, que a aula não é tão legal, eu penso que eu preciso do conteúdo." Neste conjunto de informações, interpretamos que o prazer de Mika no estudo escolar se refere mais à necessidade de responder à demanda escolar do que, efetivamente, ao prazer de incorrer em processos de aprendizagem autônomos e independentes.

Ao mesmo tempo, interpretamos, no entanto, que os momentos de pressão para aprender adquirem um forte valor nos processos de aprender em Mika. Na entrevista semiestruturada I (APÊNDICE B), ao ser perguntada sobre o pior lugar, Mika cita "Estar 
em algum lugar fazendo uma prova que eu não soubesse fazer". Na entrevista semiestruturada II (APÊNDICE C), ao ser convidada a citar três experiências negativas na escola, Mika responde

A primeira vez que fiquei de recuperação; chorei. A segunda, quando tive enxaqueca quando não consegui aprender divisão [matemática]; chorei e me senti incapaz. Estudei para no dia seguinte fazer a prova; foi a pressão que me fez.

Na entrevista semiestruturada III (APÊNDICE E), ao ser questionada sobre como se organiza para os estudos, Mika, em meio a sua resposta, relata "Tenho muito medo de prova. A partir da $5^{\mathrm{a}}$ série, eu me preocupo muito por tirar nota máxima." Mais adiante, ao responder a pergunta sobre o que sente quando aprende, Mika responde "Dever cumprido [...] Satisfeita. Eu consegui cumprir a meta. A pior coisa é você não aprender o que estão te ensinando. Orgulho de mim."

Neste conjunto de informações, interpretamos que a tensão emocional nos momentos avaliativos constitui, no histórico da vida escolar de Mika, um momento de produção subjetiva relacionado a sentidos subjetivos associados ao desafio de provar-se capaz ao outro e a si mesma. Esta produção é perpassada por sentimentos contraditórios de medo e de incapacidade, associados ao mesmo tempo a sentimentos de autoconfiança, de estímulo, de perseverança e de satisfação.

Por seu excelente histórico escolar, interpretamos que Mika tem uma relação complexa com a pressão. Ela se angustia e parece sofrer muito, ao mesmo tempo em que se fortalece com a pressão e o desafio. Com efeito, chama-nos atenção a frase, no instrumento de completamento de frases (APÊNDICE D), “69. Aprendo na pressão, alegria...". Nesta informação, interpretamos que Mika é ciente de que seus processos de aprendizagem podem ser orientados em meio a esses dois sentimentos.

No contexto do Projeto, consideramos que esse núcleo de sentidos subjetivos se expressou, principalmente, nos momentos de realização do DRP e de apresentação no Fórum. Sobre a realização do DRP, o nervoso e a forte pressão emocional se expressaram, em nossas análises, na avaliação de Mika sobre a experiência. Em suas reflexões, observamos um desapontamento com a atuação da dupla e com a dificuldade da atividade de mediação. No entanto, de forma diferenciada de Estela, consideramos em Mika uma postura mais positiva em relação à dinâmica como processo de aprendizagem e de 
pesquisa. No encontro de avaliação do DRP, ela comenta: "No Mapa Falado quase chorei, foi muito triste. $\mathrm{Eu}$ aprendi que eu preciso aprender muitas dinâmicas." Em outro momento deste mesmo encontro, o seguinte diálogo se desenvolve:

Mika: [...] e um ponto negativo foi que foi muito difícil conseguir informações do grupo. Eles tinham muito medo de falar...Da próxima vez, a gente vai fazer de diferente...

Estela: Me senti $100 \%$ reprimida; sem propriedade; não conseguia nada; sem conhecimento...

Monitor 2: Vocês acham que esperavam ouvir alguma coisa? O que você queriam ouvir?

Mika: A gente esperava ouvir além...Se no primeiro dia foi assim, como será o segundo?

[Mika e Estela pareciam nesse momento desapontadas com a própria experiência.]

Monitor 1: Mas é legal que vocês ainda falam "da próxima vez"

Monitor 2: Esse é o diferencial da metodologia participativa. Você tem que entrar aberto à o que não pode se esperar.

No encontro de avaliação geral do Projeto por equipe externa, ao refletir sobre a experiência do DRP, o seguinte diálogo se desenvolve:

Estela: $\mathrm{O} 1^{\circ}$ dia foi bacana. $\mathrm{O} 2^{\circ}$ dia foi um terror. Porque eu sou muito tímida; tinha que deixar todo mundo falar e ao mesmo tempo tinha que controlar.

Camile: Foi difícil mas foi produtivo. A gente não tinha experiência com essa coisa de mediar.

Mika: Foi difícil mas foi produtivo.

Foi a base da nossa pesquisa.

[Colocam um papel grande como representativo da experiência.]

Nesses trechos de informação, notamos que Mika ao avaliar sua experiência no DRP demonstra uma postura mais aberta, reconhecendo o desafio e a dificuldade como parte da experiência do aprender e manifestando o interesse em incorrer em novas experiências de aprendizagem.

(7) A relação com a família

Conforme já apontado, Mika é muito unida à família. Em resposta à pergunta "Qual o sentido da vida para você" (Entrevista semiestruturada I - APÊNDICE B), Mika 
cita, em primeiro lugar, a família; ao ser perguntada sobre as pessoas mais importantes para si, cita seu pai e sua mãe. Ainda no mesmo instrumento, ao ser perguntada sobre mudanças que gostaria em sua vida, expressa que gostaria de uma "renda maior, para poder estudar mais, para a mãe não precisar trabalhar tanto". $\mathrm{Na}$ entrevista semiestruturada II (APÊNDICE C), ao ser perguntada sobre lugares em que mais aprende fora da escola, Mika expressa "com pessoas mais velhas; quando chego em casa e comento o que aprendi".

No encontro do Projeto em que se realizou a dinâmica da viagem para um lugar ao qual gostaria de retornar, Mika cita a casa de sua avó, no Piauí. Cita como motivo da escolha, a vontade de auxiliar a relação dos avós com o restante da família.

Por fim, mais uma vez ressaltamos o relato de Mika sobre o teatro que ela, seus pais e seu irmão fizeram para o resto da família no Natal, como forma de explicar o seu uso do humor para lidar com a timidez. Ressaltamos ainda os diversos encontros com o seu pai, em que observamos brincadeiras entre os dois. “A gente gosta de zoá!” Mika me relata uma vez em conversa informal.

Este conjunto de informações da pesquisa nos permite a construção de que a família consiste, na subjetividade individual de Mika, um núcleo de subjetivação que integra a configuração subjetiva da ação do aprender em Mika, no contexto do Projeto, associando-se a sentidos subjetivos diversos, entre eles, à admiração, à companhia, à retribuição e à pressão para corresponder às expectativas. Sentidos subjetivos esses, por sua vez, se relacionam, em cada momento concreto, a sentimentos diversos de autoconfiança, de segurança, de pressão, e estímulo. Interpretamos ainda que este núcleo de sentidos subjetivos articula-se a uma produção subjetiva que se expressa na autovaloração de Mika como pessoa sociável, como veremos a seguir.

(8) A autovaloração como pessoa sociável

Conforme já apontado, não apenas Mika demonstra ser uma pessoa sociável e conciliadora, como também tem consciência dessas suas capacidades. 
Retomamos, como ilustrativo, sua resposta na entrevista semiestruturada I (APÊNDICE B), sobre o sentido da vida, quando responde "Família, pessoas, amigos, partilhar, brincar, sorrir." No mesmo instrumento, ao ser convidada a citar o melhor lugar, Mika responde "o ambiente é as pessoas". Na entrevista semiestruturada II (APÊNDICE C), ao falar sobre sua relação com professores, Mika expressa "Me dou bem com todos os professores; me coloco muito no lugar dos outros então eu entendo. Até as pessoas achavam que eu defendia demais".

No encontro do Projeto em que foi realizada a dinâmica da viagem, as respostas de Mika à dinâmica consistiram

[Para aonde retornaria?] Piauí; a casa da minha bisavó. [Porque?] Para passar os últimos momentos com eles. [O que levaria?] Paciência; compreensão; a forma de comunicar. [Com o que contribuiria?] Conhecimentos. [...] A minha vó acha que castanha de caju substitui o remédio. [...] Ajudaria a comunicação dos tios com a vó. Eles não sabem falar com ela [...] Usaria mais criatividade para me comunicar com o vô e a vó...no jogo de cartas, nas brincadeiras. ...O vô e a vó sorrindo com crianças [ouvem mais].

Nesta informação, chamou-nos atenção o fato de que, ao contrário de escolher o retorno a um local de prazer e diversão, Mika escolhe um local onde há desafios e problemas a serem superados. Mika não apenas se outorga o papel de conciliar as dificuldades de comunicação da família, como possui a autoconfiança de que, em sua capacidade comunicativa, resolveria positivamente os problemas.

Nessas informações, interpretamos que, ao se autoavaliar em seu jeito espontâneo, brincalhão e doce, Mika confere a si mesma um papel de mediadora de possíveis tensões ou conflitos nas relações sociais que se estabelecem. Sobre esse aspecto ainda, apontamos as seguintes informações no complementamento de frases (APÊNDICE D):

26. Meu maior problema é ser extremamente compreensível, deixando de lado as minhas próprias vontades.

27. Quero ser uma excelente profissional, mãe, amiga...

28. Creio que minhas melhores atitudes são quando me coloco no lugar do próximo e assim consigo ajudá-lo.

67. Meu maior prazer ver todos que amo felizes

72. Meu maior temor ficar só ou não conseguir ser alguém

75. Meus amigos fazem parte da minha personalidade

76. Meus colegas me completam. 
Chama-nos especial atenção as frases 26, 28 e 72 que, em nossa interpretação, apontam para a forma com que a autopercepção de Mika como pessoa sociável se integra, de maneira complexa e contraditória, a sentidos subjetivos de autocrítica e autovaloração.

Este conjunto de informações nos permitem formular um indicador de que a própria autopercepção de Mika como pessoa sociável, comunicativa e conciliadora se constitui um núcleo de sentidos subjetivos associados à relação com o outro, nos quais perpassam sentimentos contraditórios de autoconfiança, de coragem, de diferenciação e, ao mesmo tempo, de receio do confronto e de não atender às expectativas.

Consideramos que este núcleo de sentidos se expressa, de diversas formas, nos contextos educacionais e de aprendizagem em Mika.

Conforme já colocado, Mika tem preferência expressa por atividades práticas e de grupo em oposição a aulas expositivas e teóricas. Para ela, as aulas na escola deveriam ser "mais dinâmicas; as aulas são muito cansativas. Cita como momentos significativos de aprendizagem para si as oportunidades de se envolver em atividades de grupo em feiras e eventos externos que, conforme nossas observações, são muito estimulados em sua escola.

Consideramos ainda que ao se considerar como uma pessoa sociável e brincalhona, Mika se autoavalia, ao mesmo tempo, como aluna inapta para aulas e conteúdos teóricos. A própria parceria com Estela, no decorrer do ensino médio e no Projeto nos consiste indicador para essa construção. Em atividades de grupo e dinâmicas de estudo, as duas colegas estavam sempre juntas em uma parceria muito produtiva. Não obstante, Mika naturalmente delegava a Estela o papel de coordenadora, apresentadora e redatora dos trabalhos, por achá-la melhor aluna. Essa situação transparece no seguinte relato de Estela, na entrevista semiestruturada IV (APÊNDICE F), ao falar da realização do relatório do DRP, no âmbito do Projeto não-formal:

Estela: É porque eu e Mika a gente sempre trabalha junto, desde quando eu entrei na escola, desde quando a gente se conheceu a gente sempre trabalha junto. Aí, eu e ela [...] a gente sempre tem os papéis estabelecidos [...] a gente sempre tem as tarefas que a gente faz e mostra uma pra outra e vê a opinião. E foi do mesmo jeito. Foi automático até. [...] Por isso que nosso relatório tiveram coisas bastante diversificadas assim,... E como eu sou melhor na 
escrita, a Mika acabou me permitindo escrever, aí eu fiquei até quatro horas da manhã $[\ldots]$

Neste relato de Estela, consideramos que a parceria das duas, tanto na escola quanto no contexto não-formal, ainda que muito rica e produtiva, preservava Mika de situações mais desafiadoras, tais como coordenar, finalizar e apresentar trabalhos. Na escola, observamos essa situação na apresentação do grupo de Mika e Estela na Feira do Conhecimento, quando Estela conduziu e apresentou os trabalhos do grupo. No Projeto, observamos isso na atividade de mediação do DRP, conduzida nos dois dias por Estela, e na delegação da escrita do relatório de análise dos dados, conforme o relato a cima. A atitude de Mika de delegar atividades a Estela, tanto na escola quanto no Projeto, em nossas interpretações, indica sentidos subjetivos de sua relação com a aprendizagem no contexto escolar, marcados pela sua baixa autoestima como aluna aplicada e estudiosa. Contribui para esse raciocínio, uma autoavaliação de Mika, na entrevista semiestruturada IV (APÊNDICE F):

[O Projeto] me ensinou a aprender na escola. A cada módulo eram pessoas diferentes. E eles sabiam como passar. Pode falar, não tem medo de colocar sua opinião. Eles diziam "E aí, como é lá com vocês?" Eles são ótimos mediadores. Isso [me] melhorou muito. Nem tanto o conteúdo, mas mesmo sem muito conhecimento, o importante é falar.

Chama-nos atenção que a reflexão de Mika sobre sua experiência no Projeto está centrada em sua própria autoavaliação como aluna na escola. Em nossas construções, essa reflexão se constitui permeada pelos contraditórios sentidos subjetivos associados ao núcleo de sentidos subjetivos de sua autoavaloração como pessoa sociável e sua (in)capacidade para estudo escolar, mais teórico e sistemático e predominantemente individual.

Para finalizar essa seção, e de forma a sistematizar nossas construções interpretativas sobre os elementos da configuração subjetiva da ação do aprender em Mika no contexto não-formal, hipotetizamos que os aprendizados no Projeto se constituíram em meio a uma produção subjetiva que, tendo em vista as articulações entre os núcleos de sentidos subjetivos de sua relação com a aprendizagem e de sua autopercepção como pessoa sociável contribuíram para reforçar em Mika sentimentos de inaptidão para o estudo teórico, individual e sistemático, desfavorecendo sua autoconfiança e promovendo uma relação de dependência a Estela. Por outro lado, de 
forma contrária, essa produção subjetiva era igualmente marcada pela articulação de sentidos subjetivos da expressão do clima relacional e comunicacional do grupo como elemento da subjetividade social do Projeto na subjetividade individual de Mika, e do próprio núcleo de sentidos de sua autopercepção como pessoa sociável, que promoviam sentimentos de autoconfiança, de autonomia e de audácia. Aprofundaremos essa análise na seção a seguir.

\subsubsection{Características da aprendizagem de Mika no contexto não-formal}

$\mathrm{Na}$ seção anterior, apresentamos nossas análises interpretativas sobre elementos da configuração subjetiva da ação do aprender no contexto não-formal que a partir de sentidos subjetivos diversos e contraditórios, favoreciam seja uma postura de autonomia crítica, de autoconfiança e de audácia e, ao mesmo tempo, uma postura de baixa autoestima como aluna aplicada no estudo escolar. Por meio desta complexa produção subjetiva, reconhecemos, em Mika, diversos momentos de criatividade na aprendizagem no contexto não-formal.

Argumentaremos essa análise com base em nossas construções sobre as experiências de Mika em processos de personalização da informação, de confrontação com o dado, de geração de ideias novas, e de personalização da experiência da aprendizagem.

\subsubsection{Personalização da informação}

Conforme já apontado, a produção subjetiva de Mika no contexto não-formal, que se expressava, em especial, no clima relacional e comunicacional do grupo e no fazer pedagógico orientado para a prática, favorecia em Mika sua capacidade e sensibilidade de comunicação interpessoal e, portanto, a expressão de sentimentos de autoconfiança, autonomia e audácia. Com efeito, de forma diferenciada de Estela, nos momentos de debate e dinâmicas dos encontros do Projeto, Mika não se sentia na obrigação de demonstrar sua aprendizagem, relevando menos atenção ao conteúdo e permitindo-se formas mais espontâneas de aprender, tais como as reflexões pessoais, marcadas pela fluência e simplicidade de expressão. 
A forma como Mika personalizou o conceito ampliado de saúde, central na proposta do Projeto, nos consiste exemplo ilustrativo. Na entrevista semi-estruturada IV (APÊNDICE F), ao relembrar o Módulo II, Saúde e Educação, Mika relata

Não consigo achar bem as palavras, mas entendo muito a ideia de como é diferente falar da saúde como prevenção da doença, e falar da saúde como promoção da saúde. Em um, o foco é no negativo, no outro a saúde é vista como um processo, uma busca pela conquista de bem estar [...]

Neste relato, Mika demonstra uma compreensão pessoal da multidimensionalidade do conceito de saúde, marcada pelo vocabulário simples, pela não pretensão em definir um conceito fechado e pela ênfase na reflexão pessoal sobre a diferença entre as palavras prevenção e promoção. Cabe ressaltar que esta entrevista ocorreu a dois meses do término do Projeto. Consideramos, assim, que este relato reflete assim uma aprendizagem que se constituiu implicada e duradoura em Mika, expressão de sua personalização do conceito.

Outro momento em que a compreensão do conceito de saúde se expressou em Mika foi no instrumento da redação (APÊNDICE G). Nela, ao ser convidada a comentar sobre uma política de sáude pública no Brasil para solucionar o problema da falta de médicos, Mika discorre sobre a necessidade de mudar as práticas de formação, de melhorar as condições médico-hospitalares no interior e nas periferias pobres, de evitar a superlotação dos hospitais e, por fim, como medida para esse último, buscar-se o investimento na promoção de saúde. Escreve o último trecho da seguinte forma:

[...]é preciso o investimento na promoção da saúde, modificar a visão hospitalocêntrica, ou seja, promover saúde nas escolas, com crianças e adolescentes, para que a nova geração renove, mude essa situação. Pois saúde está além de hospitais, medicamentos é estar bem consigo, feliz.

Neste trecho, Mika demonstra, mais uma vez, sua compreensão do conceito de saúde ao utilizá-lo para construir sua argumentação sobre questões de política de saúde pública no país. Novamente, chama-nos a atenção sua ênfase na diferença entre os termos de prevenção e promoção da saúde, como base para a personalização do conceito.

Para além da personalização da informação, considerando nossa proposta teórica da personalização do aprendizado, apontamos dois aprendizados que emergiram, em Mika, em momentos posteriores e em contextos diferenciados do contexto do Projeto. O primeiro relaciona-se a sua maior atenção e interesse em informações sobre políticas 
públicas de saúde na grande mídia. Em conversas informais, em um dos encontros do Projeto, Mika nos comenta que se impressiona pela quantidade de informações com relação a políticas públicas de saúde que são veiculadas diariamente e que, agora, a chamam atenção. Cita, neste momento, jornais e o DFTV, programa jornalístico da Rede Globo. A emocionalidade presente em sua constatação nos permitiu a interpretação de que um relevante aprendizado do Projeto consistiu, para Mika, a forma em que ela passou a se sentir com maior autonomia de reflexão crítica frente a temas veiculados diariamente nas TVs e jornais, e a se sentir mais imersa e participante de uma dimensão político-social de nossa sociedade que lhe era irrelevante até então.

O segundo exemplo de personalização do aprendizado no Projeto em Mika, se relaciona ao seu aprendizado sobre produção e edição de vídeos, focado em especial no Módulo V - Comunicação e Mobilização Social. Em suas palavras, na entrevista semiestrutuada IV (APÊNDICE F), ela relata "De todos os módulos esse foi o que mais gostei." Este módulo apresentou um forte cunho prático, bem ao gosto de Mika, em que os participantes aprenderam a realizar a roteirização, a gravação de falas e entrevistas, a edição e a sonorização de vídeos jornalísticos. Com efeito, após o Projeto, Mika participou de dois trabalhos de produção de vídeos. O primeiro foi um trabalho, de sua realização, selecionado e exibido no evento da Central Única das Favelas do DF, em setembro de 2012 (CUFA-2012). Na ocasião, Mika ganhou a premiação concedida aos selecionados. O segundo consistiu em sua aplicação e seleção para um edital da Instituição $F$. para a realização de um trabalho videográfico. Neste trabalho, Mika foi remunerada por sua produção.

Assumimos que os momentos posteriores ao Projeto em que Mika desenvolve trabalhos de produção videográfica aconteceram, para além da personalização da informação apresentada, mas por meio da personalização da sua própria relação com a atividade de produção de vídeos, conforme a proposta pedagógica do Projeto.

Retomamos aqui, processos subjetivos em Mika associados aos núcleos de sentidos subjetivos de sua relação com a aprendizagem e de sua autovaloração como pessoa sociável, caracterizado pela produção de sentidos subjetivos diversos e contraditórios com relação a sua autoavaliação como aluna. Acreditamos que a forma como Mika personaliza a atividade de produção e edição de vídeos, a partir de suas experiências no Projeto, se constitui em meio a uma produção subjetiva que reafirma para 
ela a importância de sua sensibilidade e capacidade de expressão nas relações interpessoais como recursos relevantes em processos de aprendizagem. Consideramos ainda que este movimento subjetivo só foi possível em um contexto diferenciado do contexto escolar, tendo em vista a forma como Mika subjetiva a aprendizagem e sua própria autovaloração como aprendiz nesse contexto.

\subsubsection{A confrontação com o dado}

Em diversos momentos de debates nos encontros, observamos em Mika uma postura de reflexividade e de autonomia crítica frente ao dado, assim como frente à subjetividade social do grupo. Apontamos dois momentos em particular.

O primeiro consistiu um debate sobre o tema de regulamentação, discriminação ou liberação do uso de drogas, no módulo V, Comunicação e Mobilização. Neste momento o seguinte diálogo se coloca:

Participante 1: A liberação terminaria com o tráfico.

Monitor 1: Liberação, regulamentação e descriminação do uso de drogas são coisas diferentes. [...]

Estela: Na França, fumantes são muitos. É uma questão cultural.

Camile: Só uma pequena parcela é que sabe dos prejuízos.

Mika: Faltam maiores campanhas de conscientização...

Monitor 1: Vale lembrar que "conscientizar" é uma normatização. É dizer que "aquilo é certo e aquilo é errado." O diálogo é diferente. No diálogo a gente negocia. "Será que sabemos o bastante?"

Participante: É pode pensar em dar aos poucos.

Monitor 1: [Explica a política de redução de danos onde o drogado tem acompanhamento do Estado na hora de receber sua dose diária. Explica que poderia se pensar em regulamentar o cultivo próprio como política de redução de danos. Por fim, sugere que na Holanda, a maconha é regulamentada pelo Estado; e que muitas vezes, a política de criminalização gera a vontade de experimentar.]

[Segue-se grande discussão em que a defesa da regulamentação e a condenação à política de internação compulsória parecem prevalecer.]

Mika: Todos estão falando contra a internação compulsória. Mas e quando o indivíduo perde a própria capacidade de vontade? Tem muitos casos em que a própria família não dá mais conta. E precisa de ajuda pra se afastar. 


\section{$[\ldots]$}

Aqui, observamos em Mika uma autonomia de pensamento que a permite não só pensar em situações diferenciadas mas, inclusive, ir contra a subjetividade social que se conformou fortemente a favor das políticas de regulamentação e de condenação à internação compulsória. No calor do debate, este tipo de situação não parecia intimidar Mika que, com frequência, de forma similar a Camile, demonstrava, nos debates, autonomia crítica e capacidade de articulação de novas associações e novas perspectivas.

Apontamos como um outro momento, o fechamento do Fórum, depois de todas as palestras dos especialistas, das apresentações das análises do DRP, e dos debates nas rodas dialogadas. No momento de avaliação final, em frente a todo o auditório, Mika é a primeira a levantar a mão para sugerir um encaminhamento prático, como resultado de sua preocupação e reflexão sobre a continuidade das ações discutidas no encontro, no processo de implantação do PSE nas escolas. Neste momento, de forma muito pragmática e audaciosa, sugere, que sejam organizados, em cada escola, "pequenos grupos com o apoio da coordenação e dos professores da comunidade escolar para efetivamente conseguirmos mudanças."

Ressaltamos que estavam presentes no auditório coordenadores pedagógicos, diretores, autoridades da Regional de Ensino, professores e alunos. Ressaltamos, ainda, que grande parte das discussões do Fórum denunciou a ausência de instâncias de diálogo nas comunidades escolares. Enfatizamos a condição de sujeito, em Mika, expressa em sua tentativa audaciosa, neste momento final, de buscar assegurar o compromisso de todos os envolvidos no Fórum com as ações discutidas no evento.

\subsubsection{A geração de ideias novas}

Para além da reflexividade crítica e da confrontação com o dado, ressaltamos diversos momentos em que Mika desenvolveu novas ideias frente a questões e problemas colocados. Apontamos duas situações em particular.

Em primeiro, citamos uma reflexão colocada por Mika em um encontro do Projeto de avaliação das informações levantadas após a aplicação do DRP nas escolas. A partir de suas análises das informações expressas nos dois dias de dinâmicas, Mika conclui: 
Mika: Eu tava conversando com Estela sobre o $1^{\circ}$ e o $2^{\circ}$ dia. Todas as informações saíram da realidade de cada um ali. Todos os meninos ...[dizem coisas que] têm alguma ligação com o dia a dia. ... "Não faz parte do meu cotidiano, mas eu quero tanto ir lá que eu vou citar". [Sugerindo que as falas não expressam a realidade e sim os desejos e interesses do participante sobre a realidade.]

Monitor 2: [...] Isso!! ... Não se fala dos mendigos da escola porque todo mundo acha isso normal.

Notamos, aqui, a profunda reflexão de Mika para, em sua análise, elaborar que o expressado nos diálogos do DRP de sua escola eram informações carregadas de um valor simbólico que, em muitas vezes, correspondiam a atenções, desejos, vontades das pessoas e grupos participantes do DRP, e não às "reais" condições sociais e físicas vivenciadas na escola e na comunidade. A partir dessa ideia, Mika e Estela demonstram a necessidade de uma profunda mudança na forma como realizar a análise interpretativa do DRP. Entre todos os participantes do Projeto, Mika é a única que consegue chegar neste nível de reflexão, que não havia sido nem apresentada, nem vivenciada, nesta profundidade de análise, nos encontros preparatórios e nas simulações prévias. Consideramos que essa reflexão criativa em Mika se conforma em meio ao exercício da condição de sujeito em sua reflexão autônoma e implicada sobre a análise do DRP, à confrontação com o dado posto e à geração de uma interpretação nova frente ao problema percebido. Enfatizamos o quanto esse momento de criatividade em sua aprendizagem se constitui enquanto expressão da da configuração subjetiva da ação do aprender no contexto não-formal, em Mika, marcada por sentidos subjetivos associados à subjetividade social do Projeto e ao núcleo de sentidos subjetivos de sua autopercepção como pessoa sociável, que favoreciam sua autoconfiança em sua capacidade e sensibilidade para a comunicação interpessoal.

\subsubsection{A personalização da experiência de aprendizagem}

Com base em nossas análises, consideramos que Mika, apresentou momentos de criatividade na aprendizagem tanto em suas atuações no Projeto, quanto em suas reflexões sobre sua experiência. Conforme já apontamos, na atuação de sua dupla com Estela na aplicação do DRP na escola, o equilíbrio entre o estímulo para a participação do grupo e o controle do grupo se mostrou um dos principais desafios da mediação. Dessa maneira, 
embora Mika fosse responsável pela relatoria, com frequência a observávamos realizar intervenções para auxiliar Estela na condução da dinâmica.

Nesses momentos, a capacidade de comunicação interpessoal de Mika se expressava de formas diversas e sutis. O trecho de diálogo abaixo nos parece ilustrativo. Nele, Estela inicia com uma pergunta ao grupo:

Estela: O que vocês acham da segurança da [cidade]? [Ninguém se pronuncia e o silêncio se prolonga.]

Mika: O que vocês acham da segurança da [cidade]; tá legal ou tá assim razoável? [Gesticulando com as mãos e fazendo careta.]

Ao notar a desmobilização dos participantes, Mika rapidamente busca uma forma diferente de comunicar a pergunta. Para facilitar a compreensão e provocar o maior envolvimento dos colegas, Mika se utiliza intencionalmente de estratégias como a repetição da pergunta de Estela, a indicação de possíveis respostas em uma linguagem informal e acessível e o uso de expressão corporal. Em diversos momentos, evidenciamos essa capacidade comunicativa em Mika.

Mika ainda demonstrou uma capacidade reflexiva de análise sobre as informações que emergiam da dinâmica, buscando intencionalmente explorar temas que lhe pareciam relevantes. No Mapa Falado, quase ao fim da dinâmica, Mika acertadamente retoma um tópico sobre violência na região da cidade que lhe pareceu importante e pouco explorado.

[Depois de um longo momento, já ao final da dinâmica...]

Eu queria saber um pouco mais sobre a AR12. Como é lá? Você mora lá? Um pessoal que mora em outra AR não pode ir lá, não?

[Os meninos se animam e todos começam uma grande e rica discussão sobre a violência na AR12.]

Consideramos, assim, que níveis de criatividade na condução e na análise do DRP foram, em Mika, precisamente marcados por sua implicação emocional e por sua capacidade e sensibilidade para comunicação interpessoal.

A reflexão crítica sobre a atuação de sua dupla no DRP e a proposição de uma solução inovadora sobre a forma como apresentar a dinâmica do Mapa Falado para o grupo de sua escola consistiu outro momento de criatividade na aprendizagem em Mika. Sua principal preocupação antes e após as dinâmicas era garantir que os participantes se 
sentissem a vontade e motivados para falar. No encontro de avaliação do DRP, Mika comenta: "Eu achei que se a Estela tivesse apresentado o Mapa Falado como a Fofoca Falada de [cidade], todo mundo ia falar." No encontro de avaliação do Projeto por uma equipe externa, Mika volta a propor esse novo nome. Em nosso último encontro, da entrevista semiestruturada IV (APÊNDICE F), realizado em dezembro, três meses após o término do Projeto, Mika aponta novamente sobre o DRP:

Tinha medo da galera não entender. Tinha medo de não conseguir o resultado esperado, as informações necessárias. O Mapa Falado tinha que ter sido explicado como "Fofoca Falada".

Interpretamos que, frente a sua autoavaliação sobre a atuação de sua dupla no DRP, Mika desenvolve uma nova ideia para o problema encontrado, buscando imprimir um clima de comunicação próprio de si, com base em sua sensibilidade para a expressão e o diálogo com o Outro. Com efeito, ressaltamos novamente que esse tipo de reflexão ocorre em Mika, como expressão de sua produção subjetiva marcada por sentidos subjetivos associados aos núcleos de subjetivação do uso da brincadeira e do humor nos espaços sócio-relacionais e da autovaloração como pessoa sociável, conforme nossas elaborações prévias.

Pontuamos, por fim, que os diversos momentos de criatividade na aprendizagem analisados apresentam processos característicos da aprendizagem criativa conforme apontado nos estudos da área. Consideramos em Mika o exercício da condição de sujeito na sua autonomia crítica frente às temáticas que emergem nos debates dos encontros e na sua profunda intencionalidade reflexiva frente à conteúdos e atividades como a da análise das informações do DRP. Pontuamos, em Mika, as formas contraditórias com que ela subjetiva sua própria sensibilidade e capacidade de comunicação interpessoal em relação a processos de aprendizagem. Interpretamos que, nos momentos de debate nos encontros do Projeto, pela dinâmica pedagógica e pela subjetividade social do Projeto, sua produção subjetiva com relação a essa capacidade de comunicação interpessoal favorecia sua abertura para incorrer em novos processos de aprendizagem nesse contexto. Retomamos, aqui, a sua fala na entrevista semiestrutura da IV:

"[O Projeto] me ensinou a aprender na escola. [...] Pode falar, não tem medo de colocar sua opinião. [...] Isso [me] melhorou muito. Nem tanto o conteúdo, mas mesmo sem muito conhecimento, o importante é falar. 
Ressaltamos, assim, em Mika, a geração de sentidos subjetivos que recursivamente alimentaram o próprio processo do aprender na realização de uma pesquisa de natureza qualitativa, promovendo reflexões e mudanças sobre suas próprias representações sobre o "ser aluna" e o aprender. Consideramos, nessa movimentação subjetiva, uma expressão da dimensão funcional de sua aprendizagem criativa no Projeto. Aprofundaremos essa análise na síntese integrativa dos casos, na próxima seção. 


\subsection{Síntese Integrativa dos Casos: considerações sobre processos constitutivos da aprendizagem criativa no contexto não-formal}

Desenvolveremos, nesta seção, uma síntese de nossas construções teóricas tendo em vista nosso objetivo de pesquisa de compreender a configuração subjetiva da ação do aprender e as formas de expressão da aprendizagem criativa em um contexto não-formal de aprendizagem. Na seção anterior, realizamos nossas análises com base na expressão da aprendizagem criativa das participantes do Projeto, a partir das características distintivas deste tipo de aprendizagem e de alguns de seus processos subjetivos constitutivos.

Nesta seção, aprofundaremos aspectos, dessas características e processos subjetivos, que emergiram de forma integrada nas análises dos casos; aspectos que trazem contribuições ao arcabouço teórico da pesquisa e que, em nossas considerações, consistem pertinentes ao contexto não-formal, em oposição ao contexto formal, tradicional foco das pesquisas até o momento. São eles: a personalização da experiência da aprendizagem, o estudo empírico da expressão singular da subjetividade social na subjetividade individual do aprendiz, e a personalização do aprendizado e sua relação com processos de mudanças subjetivas.

\subsubsection{A personalização da experiência da aprendizagem}

Conforme já mencionado nas análises dos casos, assumimos por personalização da experiência da aprendizagem como as formas com que os processos do aprender, que se constituem na experiência prática e na reflexão sobre essa experiência, se integram à subjetividade do aprendiz.

A proposição da personalização da experiência da aprendizagem como novo elemento teórico para a compreensão da aprendizagem criativa em contextos não-formais de aprendizagem, ocorreu a partir das considerações de que, nos três casos analisados o desenvolvimento de uma nova representação sobre a ciência e o fazer científico ocorreu não apenas por meio da personalização da informação, transmitida como conteúdo curricular do curso de capacitação, mas principalmente por meio da própria experiência vivida de realização da pesquisa qualitativa e da reflexão sobre essa experiência. Com 
efeito, conforme nossas análises interpretativas dos casos, elaboramos que a criatividade na aprendizagem se expressou seja na geração de novas formas do fazer na experiência de aprendizagem, seja na geração de novas ideias na reflexão sobre a experiência.

Em Camile, apontamos os níveis de criatividade na aprendizagem tanto em suas atuações como mediadora e relatora da dinâmica do DRP, quanto na reflexão sobre sua experiência. Consideramos que estas atuações emergiram como expressão de sua configuração subjetiva da ação do aprender no contexto do Projeto, marcada por produções subjetivas relacionadas a sua implicação com as temáticas político-sociais do Projeto e a sua história de atuação político-social no Grêmio estudantil e no movimento social de sua cidade. Com efeito, conforme apontado na seção anterior, essa configuração subjetiva favorecia, em Camile, sua motivação, sua autonomia e sua audácia no contexto do Projeto, o que a permitia ir sempre além do que lhe era demandado. É neste contexto de produção subjetiva que, da personalização de sua experiência no Projeto, emerge uma reflexão nova sobre o fazer científico, que a permite desenvolver uma nova representação que aproxima a ciência de sua vida cotidiana e que a inclui ativamente como pesquisadora, capaz de problematizar, interpretar informações e fazer análises de sua realidade escolar. "[...] todo mundo pensava que a gente ia... ficar fazendo questionário. [...] a gente fez na verdade uma pesquisa, mas foi assim...Tinha um preparo gigante, não foi do jeito que a gente imaginava.” (Entrevista semiestruturada IV - APÊNDICE F)

Em Estela, apontamos, ao contrário de Camile, a enorme dificuldade na tarefa de mediar as dinâmicas do DRP. Conforme analisado, consideramos que esta dificuldade se constituiu em meio a uma produção subjetiva (em que o núcleo de sentidos subjetivos de aceitação e reconhecimento social, em articulação com outros elementos subjetivos, tais como o da relação com o clima relacional e comunicacional de abertura e confiança do grupo e do núcleo subjetivo de sua relação com a aprendizagem como processo obrigatório) não favorecia sua capacidade de improviso e exposição pessoal. Não obstante, compreendemos que foi precisamente a forma como Estela subjetivou essa experiência, a partir de sentidos subjetivos relacionados a sua orientação a corresponder às demandas e a ser bem avaliada, articulando-se a sua produção subjetiva de autocrítica e de busca por independência e autonomia, o que promoveu, em nossas análises, sua imaginação e reflexão criativa sobre o fazer científico a partir da forma como se autoavaliou e resignificou suas próprias experiências. “... era como se eu, um número da sociedade, tivesse que apagar todos os meus infinitos pontinhos e permitisse que os outros 
números me preenchessem com seus pontinhos." (Entrevista semiestruturada IV APÊNDICE F) Consideramos que, neste e nos outros processos autorreflexivos de Estela, posteriores ao contexto do Projeto conforme apontado na página 143, ela demonstra o exercício da condição de sujeito frente suas próprias vulnerabilidades pessoais, desenvolvendo, a exemplo de Camile, uma nova representação de ciência que a inclui ativamente como pesquisadora, com maior atenção a capacidades de abertura pessoal, de escuta a críticas e de interpretação livre de "verdades que vão sempre ser questionadas" (Entrevista semiestruturada IV - APÊNDICE F).

Em Mika, por sua vez, a personalização da experiência no Projeto é marcada por sua própria autoavaliação como aluna no contexto escolar: "[O Projeto] me ensinou a aprender na escola...Nem tanto o conteúdo, mas mesmo sem muito conhecimento, o importante é falar" (Entrevista estruturada IV - APÊNDICE F). Em nossas construções, consideramos que a personalização da experiência de aprendizagem no Projeto é marcada em Mika por sentidos subjetivos contraditórios associados ao núcleo de sentidos subjetivos de sua autovaloração como pessoa sociável e sua (in)capacidade para estudo escolar, constituintes de sua configuração subjetiva da ação do aprender no Projeto. Com efeito, sua reflexão sobre a experiência emerge como expressão dessa complexa produção subjetiva.

A proposição da personalização da experiência da aprendizagem pressupõe duas ações específicas que se tornam relevantes em contextos de aprendizagem menos estruturados, como os contextos não-formal e informal: em primeiro, a própria percepção do engajamento em uma experiência de aprendizagem, em segundo, a reflexão sobre essa experiência.

Diversos autores já preconizaram a importância da interação entre a teoria (conceitos abstratos) e a experiência nos processos de aprendizagem (DEWEY, 1938; KOLB, 1984; ROGERS, 2001). Em Dewey, o aprender fazendo foca a experiência pessoal do aprendiz e a centralidade de seus interesses como condições para uma aprendizagem que favoreça processos de inteligência, de imaginação e de criação (TARDIFF, 2010). Na proposta da aprendizagem experiencial de Kolb, a construção do conhecimento se dá com base em processos de preensão e transformação da experiência que, em seu modelo, ocorrem em ciclos com etapas específicas de experienciar, refletir, generalizar e aplicar. Na aprendizagem como autodescoberta, Carl Rogers, por sua vez, 
afirma o lugar central da experiência e da reflexão pessoais na construção de si mesmo, aderindo a uma visão de educação fundada no desenvolvimento integral do aprendiz (ROGERS, 2001; TARDIFF, 2010).

Apontamos dois motivos, em especial, para a proposição teórica da personalização da experiência da aprendizagem como elemento da aprendizagem criativa no contexto não-formal. Em primeiro, as especificidades próprias do contexto não-formal, entre elas, conforme já mencionado, o voluntarismo, a não obrigatoriedade, a ausência de rotinas de estudo sistemáticas e de avaliação de aprendizagem, entre outras. Em contraposição à aprendizagem escolar, marcada pela rotina sistemática do ensino e da aprendizagem dos conteúdos, a maior liberdade e autonomia do aprender no contexto não-formal exige do próprio aprendiz processos como: a seleção do que quer aprender, a percepção da forma como aprende e a reflexão sobre a experiência como forma do aprender.

Em contextos não-formais de aprendizagem, torna-se a relevante pergunta: o que nos leva a nos engajar nesses processos?

Com base nos casos analisados, apontamos que para cada uma das participantes, na singularidade e complexidade constitutiva de suas respectivas configurações subjetivas da ação do aprender, a percepção da aprendizagem e a reflexão sobre a experiência foram favorecidas por dois aspectos. No caso de Camile, pela aproximação das temáticas do contexto não-formal ao seu histórico interesse e motivação para atuações político-sociais que a acompanhava nos diversos contextos relacionais de sua vida: a escola, a cidade, o Projeto. No caso de Estela e Mika, nas formas subjetivas com que o elas relacionavam a experiência de aprendizagem vivida e os aprendizados a processos psicológicos de vulnerabilidades e desafios pessoais. Tanto em Estela quanto em Mika, as reflexões sobre ciência e o fazer científico foram permeadas por produções subjetivas marcadas por autocríticas relacionadas à necessidade de reconhecimento social e dificuldade de errar e ouvir críticas (no caso de Estela), e à própria autopercepção como aluna na escola (no caso de Mika).

Tendo em vista essas considerações, assumimos que, para além da mobilização de recursos subjetivos relacionados à tais como a abertura ao novo, a relação com o desconhecido, a reflexividade e a autonomia crítica, já apontados pelas pesquisas (AMARAL, 2011; MITJÁNS MARTÍNEZ, 2009b, 2012a, 2012b), implicaram-se também recursos subjetivos relacionados à conversão da experiência em aprendizagem 
por meio da percepção da própria experiência e à capacidade de reflexão sobre ela. Assumimos que essa mobilização subjetiva se estabelece como relevante na aprendizagem criativa no contexto não-formal, por caracterizar processos de aprender em contextos menos estruturados, que conferem maior autonomia ao aprendiz para a aprendizagem contínua e para a vida.

Aproximamo-nos da perspectiva da aprendizagem significativa de Rogers (1997, p. 328), em que a pessoa aprende a

estar mais aberto à sua experiência integral - tanto no que lhe é interior como exterior. [...] aprende a ser mais a sua experiência...Torna-se uma pessoa mais flexível, mais modificável, mais capaz de aprender.

Ressaltadas as diferenças teórico-epistemológicas frente à abordagem humanista do autor, compartilhamos com Rogers o entendimento de que a personalização da experiência da aprendizagem se relaciona tanto ao aprendizado, quanto à reflexão pessoal sobre a forma do aprender; ao que Rogers se refere, respectivamente, como o que lhe é “interior" e "exterior". Relaciona-se ao desenvolvimento da condição de sujeito que aprende perante suas contínuas experiências de vida; o que se expressa em uma maior autonomia da pessoa em incorrer, de forma espontânea e auto-orientada, em novos desafios e inquietações, de forma a significar e ressignificar suas experiências.

A autorreflexividade sobre as próprias experiências implica a ponderação sobre a própria condição de aprendiz e as formas do aprender. Importam, assim, questionamentos como: porque a aprendizagem ocorreu dessa forma? $\mathrm{Ou}$, como essa forma de aprender favoreceu ou não a aprendizagem? (Questões que não costumam emergir no contexto escolar, formal, marcado pela rotina e por formas mais sistemáticas de ensino e estudo.)

Vale, aqui, retomarmos as pesquisas sobre a identidade e o sentido de self dos visitantes aos espaços da educação não-formal e o entendimento comum a essas pesquisas de que experiências de aprendizagem não-formal afetam de diferentes formas a identidade do aprendiz, conforme citado no capítulo I (KELLY, 2002, 2007; FALK, 2004, 2006). Com efeito, a partir de nossas análises empíricas, podemos construir que a personalização da experiência da aprendizagem em Camile, em Estela e em Mika esteve 
subjacente a processos identitários relacionados às formas com que elas se percebiam e/ou atuavam como aprendizes no espaço do Projeto. ${ }^{17}$

O segundo motivo para a proposição da personalização da experiência da aprendizagem como elemento da aprendizagem criativa no contexto não-formal se baseia na própria natureza dos objetivos de ensino do Projeto. Cabe, aqui, reproduzi-los, conforme disposto no Projeto Político Pedagógico. Segundo o documento, o curso deverá:

\section{Objetivo Geral:}

$>$ Capacitar nove estudantes de ensino médio da rede pública [...] para atuarem de forma participativa no PSE.

Objetivos Específicos:

$>$ Construir conhecimentos sobre Saúde e Educação, PSE, Democracia e Participação Social, Mídias Sociais

D Executar e avaliar o DRP - Diagnóstico Rápido Participativo

$>$ Desenvolver expertise para compreender e atuar em suas comunidades

$>$ Sensibilizar os jovens para que atuem como protagonistas multiplicadores e promovedores de mudança social em sua comunidade

Percebemos que, para além da aprendizagem de conteúdos, o curso buscou oportunizar a aprendizagem de ações relacionadas à atuação prática que podem ter real repercussão na vida escolar dos participantes. O curso prevê a capacitação para o desenvolvimento de uma investigação científica de abordagem qualitativa, que envolve a aplicação de dinâmicas, o levantamento e a análise de informações e, por fim, a divulgação das análises. Prevê-se, ainda, a sensibilização dos jovens para que atuem como multiplicadores de ações de mobilização social e protagonismo juvenil na escola, no âmbito do PSE, em momentos posteriores ao Projeto. Ressaltamos a diferença entre esses objetivos de ensino e os tradicionalmente encontrados no contexto escolar, onde a orientação primeira é a transmissão do conhecimento materializado nos conteúdos curriculares. Não se trata de dizer que tipos de objetivos como os do Projeto não sejam desenvolvidos no cotidiano escolar; trata-se, no entanto, de reconhecer que, no contexto escolar, objetivos desta natureza são, em geral, adjacentes aos objetivos de apreensão de conteúdos curriculares, em especial, no ensino médio.

\footnotetext{
${ }^{17}$ Por não terem consistido nosso foco de pesquisa, nossas construções teóricas sobre as inter-relações entre a personalização da experiência da aprendizagem no Projeto e processos relacionados à identidade de aprendizagem dos participantes serão abordadas em artigo específico, posterior ao presente trabalho.
} 
Em nossas considerações, para além da transmissão de conceitos e conhecimentos curriculares próprios do contexto formal, no que tange a objetivos de ensino enfatizados nos contextos não-formais, como objetivos que visam a desenvolver novas formas de atuação política e social, novas atitudes, representações e valores sobre temáticas específicas, a capacidade de aprender no fazer e na reflexão sobre o fazer torna-se um relevante recurso subjetivo para a criatividade na aprendizagem.

\subsubsection{A expressão singular da subjetividade social na subjetividade individual do aprendiz}

Em nosso processo construtivo-interpretativo, elaboramos que elementos da subjetividade social do grupo no contexto do Projeto se expressaram de forma singular na subjetividade individual de cada uma das participantes, integrando suas respectivas configurações subjetivas da ação do aprender no contexto do Projeto. Consideramos ainda que esses elementos subjetivos foram significativos para a emergência da criatividade na aprendizagem nos três casos analisados.

Em Camile, por exemplo, a expressão do elemento da subjetividade social do clima relacional e comunicacional de abertura e de confiança do grupo articulada a sentidos subjetivos dos núcleos do reconhecimento do grupo de suas experiências no grêmio estudantil e no movimento social, e da conturbada saída da escola de ensino médio (contraditórios em relação a suas atuações políticas) resultou, em nossas análises, constituinte de sua implicação com as temáticas do Projeto, e de sua postura ativa e crítica em relação aos conceitos sobre "protagonismo juvenil" e de "ativismo de sofá".

Em Estela, por outro lado, a expressão do mesmo elemento da subjetividade social do clima relacional e comunicacional de abertura e confiança do grupo, relacionava-se a sentidos subjetivos que se expressavam na relação com o grupo e com o fazer pedagógico dos monitores, associando-se, ao mesmo tempo, a sentimentos de surpresa e admiração pelo nível de espontaneidade e de liberdade de opiniões, e de desconforto nos debates. Esta produção subjetiva, articulada ao núcleo de sentidos subjetivos da necessidade de aceitação social e do reconhecimento social de seu desempenho, constituído por sentidos subjetivos relacionados à necessidade de ser reconhecida como boa aluna, à vontade de corresponder às expectativas familiares e, ao mesmo tempo, à busca por independência e 
autonomia e a sentimentos de contentamento/descontentamento, conforto/desconforto consigo mesma, constituiu, em nossas análises, sua autoavaliação negativa sobre sua atuação no DRP, desdobrando-se na decorrente reflexão criativa sobre o fazer científico.

Em Mika, por outro lado, a expressão do clima relacional e comunicacional de abertura e confiança do grupo, relacionava-se a sua autoestima frente a sua capacidade de comunicação interpessoal, à sua condição de mascote do grupo e de ser sempre o centro das atenções nos momentos informais do Projeto. Com efeito, sentidos subjetivos relacionados a esse elemento da subjetividade social promoviam, em Mika, sentimentos de autoconfiança, de autonomia e de audácia. Não obstante, essa mesma produção subjetiva articulava-se a sentidos subjetivos dos núcleos da autovaloração como pessoa sociável e da relação com a aprendizagem; o que, de forma contraditória, contribuía para sentimentos de inaptidão para o estudo teórico, individual e sistemático, desfavorecendo sua autoconfiança e promovendo uma relação de dependência a Estela. Em nossas análises interpretativas, comportamentos e atitudes de Mika expressaram essa produção subjetiva contraditória como, por exemplo, a delegação à Estela da mediação do DRP e da escrita do relatório e, ao mesmo tempo, a sua postura altamente participativa, marcada pela capacidade de crítica e de uso do humor, nos momentos dos debates nos encontros.

Evidenciamos nas análises acima que a subjetividade social não se constituiu como um processo homogêneo, igualmente compartilhado pelo grupo, mas enquanto expressão altamente singular que existe apenas na trama sentidos subjetivos da subjetividade individual da pessoa no curso de sua ação.

Importante ressaltar ainda que, entre os elementos da subjetividade social do grupo, por nós elaborados, nem todos se expressaram na subjetividade das três participantes da pesquisa. Citamos, por exemplo, a expectativa da aplicação do DRP na escola e da apresentação no Fórum como desafios a transpor. Em nossa interpretação, pelas razões já apresentadas no último caso, esse elemento da subjetividade social do grupo não se expressou nem em Camile, nem em Estela. Nesta construção interpretativa, destacamos novamente a compreensão de que a subjetividade social de um grupo não se expressa de forma igual e homogênea a todos os membros do grupo, senão de forma singular, permeada por outras produções subjetivas da pessoa.

Na consideração das formas singulares de expressão da subjetividade social na constituição subjetiva individual das participantes, retomamos aqui o valor 
heurístico da categoria configuração subjetiva da ação, conforme proposição teórica desenvolvida por González Rey e apresentada no capítulo II. Ressaltamos a proposição desta categoria como um movimento do autor para ênfase no caráter processual, aberto e atual de organização subjetiva à qual elementos subjetivos da subjetividade social, da personalidade, do motivo, e de sentidos subjetivos produzidos no curso da ação da pessoa, se desenvolvem como uma conformação de sentidos subjetivos qualitativamente diferenciada no momento da ação.

Estas considerações teóricas, em nosso entender, têm decorrências significativas para o próprio valor heurístico dos conceitos de aprendizagem formal e não-formal. A consideração de que a própria organização subjetiva do aprendiz se constitui de forma diferenciada em diferentes contextos de aprendizagem nos impele, desde já, a considerar a importância da experiência de aprendizagem em contextos diversos, para além do contexto escolar, que consiste hegemônico nas primeiras duas décadas de vida dos jovens em nossa sociedade. Corroboramos, assim, as ideias de Gohn (2011) e Garcia (2008) sobre a importância da heterogeneidade das formas da educação nãoformal (com relação à liberdade de conteúdos e de práticas pedagógicas) para a formação e o desenvolvimento integral de cidadãos ao longo da vida e em contextos diversos.

\subsubsection{A personalização do aprendizado e sua relação com processos de mudanças na subjetividade do aprendiz}

Conforme já apontado, a proposição da personalização do aprendizado amplia a formulação teórica sobre a personalização da informação de González Rey e Mitjáns Martínez. Para os autores, a informação personalizada (MITJÁNS MARTÍNEZ, 1989),

indica a informação que, pela significação que tem para o aprendiz e pela forma em que se relaciona com ela, torna-se um recurso subjetivo. [...]Ou seja, não se trata de uma informação assimilada apenas de forma compreensiva, mas de uma informação que se transforma, em alguma medida, ao articular-se no sistema subjetivo da qual passa a fazer parte."

Com a personalização do aprendizado, por sua vez, buscamos enfatizar as formas com que, não apenas a informação mas o próprio aprendizado resultante de ações e experiências do indivíduo, se converte em recurso subjetivo por meio do modo como 


\section{se integra à subjetividade do aprendiz e emerge em momentos e contextos diferenciados do contexto de aprendizagem em si.}

Em Camile, por exemplo, apontamos a personalização do aprendizado com base na forma com que as informações sobre mobilização social e suas atuações e experiências no Projeto se convertem em uma nova atitude sobre ações de mobilização política social que emerge em diferentes momentos e contextos posteriores de sua vida: a atualização e animação da página construída pelo Projeto em rede social e a filiação a um grupo de extensão da universidade.

Enfatizamos, assim, a dimensão relacional entre o aprendiz criativo e seu aprendizado. Aproximamo-nos da proposição de Carl Rogers (1997, p. 406) quando o autor sugere que o processo criativo se trata

[...] da emergência na ação de um novo produto relacional que provém da natureza única do indivíduo por um lado, e dos materiais, acontecimentos, pessoas ou circunstâncias da sua vida, por outro. (ênfase nossa)

Esta dimensão relacional à qual o autor se refere expressa-se, em nossa concepção teórica, na movimentação subjetiva que o ato de criar e o produto criativo desencadeiam na subjetividade do sujeito que cria. Em nosso caso, na produção subjetiva qualitativamente diferenciada que o aprendiz realiza em relação ao seu aprendizado.

A personalização do aprendizado criativo remete-nos à construção teórica de Mitjáns Martínez sobre a dimensão funcional da criatividade na aprendizagem criativa e seu potencial tanto para reestruturar ou constituir novas configurações subjetivas, quanto para desenvolver novas formas de funcionamento do sujeito psicológico, caracterizadas pela capacidade de desenvolvimento de alternativas autônomas, perante situações significativas e pelas rupturas singulares com o instituído no contexto da ação (MITJÁNS MARTÍNEZ, 2009a, 2012a). Na compreensão da dimensão funcional do processo criativo, o valor e a novidade consagram-se no próprio funcionamento psíquico do sujeito, em detrimento do valor do "produto criativo" como tal.

Com a personalização do aprendizado criativo, enfatizamos o envolvimento subjetivo, qualitativamente diferenciado do aprendiz com o seu próprio aprendizado, assumindo que é precisamente esse envolvimento que desencadeia 


\section{mudanças da subjetividade que "transformam" o aprendizado em recurso subjetivo, favorecendo sua expressão em diferentes contextos e momentos da vida.}

A partir desses entendimentos, construímos, no curso de nossas análises, que, no contexto do Projeto, processos de personalização do aprendizado nas três participantes da pesquisa se constituíram como mudanças em produções subjetivas, constituintes da configuração subjetiva da ação do aprender no Projeto e, ao mesmo tempo, relacionadas a experiências anteriores ao Projeto.

No caso de Camile, consideramos que suas atuações, de manutenção da página construída pelo Projeto em rede social e de filiação a um grupo de extensão da universidade, se relacionam a sua produção subjetiva frente a suas atuações políticosociais na escola, à forma como ela personalizou informações, tais como os conceitos de protagonismo juvenil e de comunicação e mobilização social, e à forma como personalizou suas próprias atuações e experiências no Projeto. Conforme analisado, compreendemos que seus aprendizados no Projeto se constituem em meio a uma produção subjetiva marcada pelo núcleo de sentidos subjetivos da conturbada saída da escola, caracterizado pela produção de sentidos subjetivos diversos e contraditórios com relação à continuidade de suas atuações políticas, a partir de suas experiências no grêmio estudantil.

Interpretamos, assim, que a personalização do aprendizado com relação à atuação política e social, no Projeto, promoveu, em Camile, um movimento subjetivo que modifica a relevância da conturbada saída da escola enquanto núcleo subjetivo, reafirmando para si sua motivação e sua autoconfiança para o contínuo engajamento em movimentos sociais e em atividades de representação política. Assumimos, assim, que suas atuações posteriores como responsável pela manutenção da Página na rede social e como membro do grupo de extensão na universidade consistem expressões dessa mudança em sua subjetividade.

Em Estela, consideramos como expressões da personalização do aprendizado sobre o conhecimento e o fazer científico, as subsequentes autorreflexões sobre sua experiência no Projeto e os diálogos consigo mesma que estas reflexões desencadeavam. “Tive tanto contato com tanta diversidade será que a minha cultura está certa?" (Entrevista semiestruturada IV - APÊNDICE F) "Por mais que você tenha uma verdade 
comprovada, essa verdade vai sempre ser questionada." (Entrevista semiestruturada IV APÊNDICE F) "Eu conheci e superei meus limites" (Fala final no Fórum). Interpretamos que essas reflexões se constituem em meio a uma complexa produção subjetiva, marcada pela forma como ela subjetiva o clima relacional e comunicacional do grupo do Projeto e pelos núcleos de sentidos subjetivos de necessidade de aceitação e reconhecimento social, que se associavam, no contexto do Projeto, a constantes sentimentos de surpresa e desconforto pela liberdade e diversidade de temas e opiniões. Consideramos que essas autorreflexões são expressões de uma nova produção subjetiva realizada, por Estela, no curso de suas ações no Projeto, que a permite formas mais flexíveis de significar a si mesma e a suas próprias experiências. Retomamos, aqui, a ideia de González Rey de que o sujeito representa "um momento de contradição e confrontação não somente com o social mas também com sua própria constituição subjetiva que apresenta um momento gerador de sentido de suas práticas” (2005, pg.240).

Em Mika, por sua vez, apontamos, como personalização do aprendizado no Projeto, as formas como subjetivou a atividade de produção de vídeos, desenvolvendo-a em diversos momentos posteriores ao Projeto. Em nossas análises, interpretamos que as aprendizagens de Mika, em especial no Módulo V - Comunicação e Mobilização sobre roteirização, apresentação e direção de vídeos, foram permeadas de uma produção subjetiva que reafirmava para ela sua sensibilidade e capacidade de expressão nas relações interpessoais como recursos relevantes em processos de aprendizagem. Esta nova produção subjetiva se expressava em oposição a sentidos subjetivos associados aos núcleos de sua autovaloração como pessoa sociável e de sua relação com a aprendizagem, que constituíam sua autopercepção como aluna inapta ao estudo escolar.

Nos três casos, analisamos que os aprendizados, respectivamente, da atuação política e social, da ciência e do fazer científico e da produção de vídeos, foram constituidores de novas produções subjetivas que perpassaram outros momentos e contextos para além do momento do aprender. Consideramos ainda que essa nova produção subjetiva tencionou formas anteriores da organização subjetiva o que nos permite hipotetizar sobre a ocorrência de mudanças subjetivas.

Em síntese, considerando o movimento subjetivo desencadeado por aprendizados com a experiência no Projeto, hipotetizamos que, em Camile, a movimentação subjetiva se constituiu como uma mudança em sua subjetividade, em decorrência da reorganização 
do núcleo de sentidos subjetivos de sua conturbada saída da escola, que a faziam duvidar sobre suas atuações políticas. Em Estela e Mika, hipotetizamos que mudanças subjetivas ocorreram na medida em que seus aprendizados no Projeto desdobraram-se na crescente relevância de novos e contraditórios sentidos subjetivos com relação à auto-avaliação sobre suas posturas como pessoa e como aluna, respectivamente.

\subsubsection{Síntese integrativa em relação aos objetivos da pesquisa}

Objetivávamos, neste estudo, compreender a constituição da configuração subjetiva da ação do aprender e as formas de expressão da aprendizagem criativa em um contexto não-formal de aprendizagem. Com esse objetivo, desenvolvemos nossas análises dos casos com base na expressão da aprendizagem criativa das participantes do Projeto, a partir de características distintivas deste tipo de aprendizagem e de alguns de seus processos subjetivos constitutivos.

Subscrevemos às pesquisas anteriores (AMARAL, 2011; AMARAL e MITJÁNS MARTÍNEZ, 2009; MITJÁNS MARTÍNEZ, 2009b, 2012a) que, sob nossa opção teórica, caracterizam a aprendizagem criativa com base em processos de personalização da informação, de confrontação com o dado e de geração de novas ideias. Subscrevemos ainda a alguns dos outros processos subjetivos constitutivos da aprendizagem criativa, também apontados pelas pesquisas, entre eles o exercício da condição de sujeito, a produção subjetiva que recursivamente alimenta novas aprendizagens, e a imaginação.

Em nosso processo de construção teórica, no entanto, considerando as especificidades da aprendizagem criativa no contexto não-formal, apontamos três contribuições da pesquisa. Em primeiro, a proposição de uma contribuição teórica nova, formulada como a personalização da experiência da aprendizagem. Em segundo, o estudo empírico da expressão singular da subjetividade social na subjetividade individual do aprendiz. Muito embora a Teoria da Subjetividade já pressuponha a formulação sobre as formas singulares de expressão da subjetividade social nas subjetividades individuais, estudos empíricos nesta são pouco expressivos. Em terceiro, ampliamos as formulações existentes sobre a personalização da informação, desenvolvendo o que denominamos a personalização do aprendizado. 
Nossas análises nos levaram, ainda, à proposição de duas novas contribuições: o estudo empírico da expressão singular da subjetividade social na subjetividade individual do aprendiz e a personalização da experiência da aprendizagem.

Cabe-nos, aqui, sintetizar nossas considerações sobre as construções teóricas realizadas e sua relevância e aderência ao contexto não-formal de aprendizagem, objeto de pesquisa de nosso estudo.

No curso de todo o trabalho, ressaltamos insistentemente as características de espaços não-formais de aprendizagem relacionadas a não obrigatoriedade, à ausência de rotinas de estudo e de instrução sistemática, ao apelo ao lúdico, à ausência de métodos avaliativos, à liberdade e autonomia de escolha sobre o que aprender, entre outros. A constante reflexão sobre essas características consistiu o pano de fundo para nossas construções teóricas.

O interesse pelo contexto não-formal como objeto de estudo nos levou à necessidade de compreender o papel do contexto de aprendizagem na organização subjetiva do aprendiz e em seus processos do aprender; o que, por sua vez, nos levou a aprofundar análises sobre a expressão da subjetividade social na subjetividade individual do aprendiz e, em decorrência, sobre a categoria teórica da configuração subjetiva da ação do aprender.

No caso da personalização do aprendizado, o foco está na forma como o aprendiz subjetiva a sua relação com o aprendido. Como vimos, em Mika, por exemplo, isso se expressa na atividade de produção de vídeos que se torna recorrente em sua vida em momentos para além do contexto do Projeto. No caso da personalização da experiência de aprendizagem, o foco está na forma como o aprendiz subjetiva a experiência do aprender, considerando a ação e a reflexão sobre a ação no processo de aprendizagem. Nos casos de Camile e Estela, por exemplo, vimos que foi a reflexão sobre a própria experiência de mediação do DRP que desencadeou processos reflexivos pessoais que se converteram em aprendizados sobre a ciência e o fazer científico.

Conforme apontado na introdução do trabalho, o conceito de educação não-formal surge na contraposição à histórica hegemonia da educação formal em nossa trajetória histórico social. De forma intencional ou não, esta contraposição permeou a pesquisa 
como um eixo reflexivo essencial na busca pela compreensão de processos subjetivos constitutivos da aprendizagem criativa no contexto não-formal. Tendo em vista os objetivos de pesquisa, nosso caminho de construção teórica nos permitiu o desenvolvimento da tese de que características e processos subjetivos constitutivos da aprendizagem criativa em contextos não-formais adquirem, sim, especificidades próprias desses contextos, sendo marcados pela maior ênfase na autonomia por parte do aprendiz em processos de seleção do que aprende, de percepção da forma como aprende e de conversão da própria experiência em aprendizagem. A autonomia nesses processos se torna relevante tendo em vista contextos menos estruturados de ensino e aprendizagem, como os não-formais e os informais, que se colocam para a pessoa em uma perspectiva de aprendizagem contínua e para a vida, para além do aprender em contextos formais. 


\section{CONSIDERAÇÕES FINAIS}

Conforme o disposto na seção anterior, consideramos que nosso caminho construtivo interpretativo de pesquisa confirma nossa hipótese interpretativa inicial de que há especificidades próprias nos processos subjetivos constitutivos da aprendizagem criativa em contextos não-formais.

Sob o ponto de vista da busca pela construção de novas zonas de inteligibilidade, conforme a proposição de pesquisas pautadas na Epistemologia Qualitativa, deparamonos com dois grandes desafios. O primeiro consistiu a própria proposta de analisar a aprendizagem não-formal sob a perspectiva da subjetividade, em uma aproximação até então não explorada sobre esses dois diferentes temas. O segundo desafio relacionou-se à nossa opção, frente às particularidades do contexto não-formal analisado, por aprofundarmo-nos nas categorias de configuração subjetiva da ação e de núcleos de sentidos subjetivos, como meios para nossas construções interpretativas e elaborações teóricas. A decisão por esta opção pautou-se nas constantes inquietações e reflexões no decorrer da pesquisa, sobre as formas de gerar inteligibilidade sobre a aprendizagem em contextos tão específicos quanto o do Projeto analisado, considerando sua proposta pedagógica, sua duração, suas diversas equipes envolvidas, os espaços físicos utilizados, assim como suas características, próprias do contexto não-formal, de voluntarismo, de ausência de avaliação, de ausência estudo sistemático, entre outros.

Consideramos que as análises e elaborações construídas no caminho da pesquisa oferecem contribuições para o campo da aprendizagem não-formal a partir da rota singular do participante, como indivíduo constituído em sua história singular de vida, capaz de produzir sentidos e significados sobre sua experiência que, de forma única, impactam seus processos de memória e de reutilização do aprendido. Retomamos, aqui, as críticas de Falk $(2003$, 2004) a pesquisas sobre aprendizagem em museus, cujas abordagens teóricas, sejam elas construtivistas, socioculturais, ou mesmo do próprio Modelo Contextual desenvolvido pelo autor, falham em compreender os processos do aprender em indivíduos singulares que vivenciam a experiência do aprender de forma única e que são impactados por essa experiência para além dela, em outros contextos e momentos de suas vidas. Tendo em vista essas considerações, acreditamos que a presente pesquisa, com base nas construções interpretativas realizadas, nos permite satisfatoriamente confirmar o argumento de que processos de aprendizagem não resultam 
da articulação direta de múltiplos fatores, entre eles o emocional, o cognitivo, o social e o ambiente físico, mas se constituem como expressões de momentos vivos de produção simbólico-emocional do aprendiz. Produção, histórica e atual, marcada por processos subjetivos constituintes da configuração subjetiva da ação do aprender no contexto onde a aprendizagem ocorre.

No campo da aprendizagem criativa, a presente pesquisa traz duas contribuições, em especial. Em primeiro, propõe a personalização da experiência da aprendizagem como processo subjetivo constitutivo da aprendizagem criativa no contexto não-formal. Neste processo, ressaltamos que a abertura para o engajamento na atividade de aprender, a disposição para lidar com o desconhecido e a capacidade de reflexão sobre a experiência de aprendizagem se convertem em importantes recursos subjetivos tendo em vista a autonomia do aprendiz para a aprendizagem contínua e para a vida. Em segundo, propõe ampliar e aprofundar a compreensão sobre a formulação teórica da personalização da informação, explorando a personalização do aprendizado e suas inter-relações com mudanças na subjetividade da pessoa.

No campo da subjetividade, consideramos que a presente pesquisa oferece contribuições com relação ao estudo empírico das formas singulares de expressão da subjetividade social nas subjetividades individuais. Apesar de ser esta uma elaboração teórica já considerada pela Teoria da Subjetividade, González Rey não tem desenvolvido estudos empíricos sobre este aspecto. De forma similar, a pesquisa oferece ainda contribuições teóricas para uma compreensão mais precisa da categoria da configuração subjetiva da ação, uma vez que o autor também não tem desenvolvido estudos de campo sobre esta formulação.

Por fim, com relação a contribuições metodológicas, consideramos que a pesquisa inovou na forte ênfase e na longa duração do momento de construção do cenário de pesquisa. Com efeito, na primeira fase de campo da pesquisa, optamos por privilegiar os cinco primeiros meses da pesquisa à presença ativa e à observação no curso de capacitação do Projeto, conjugando, nesse momento, tanto a construção de vínculos de confiança, de abertura e de implicação com a pesquisa junto às participantes, quanto a realização de observações e conversas informais tendo em vista a construção de informações e de análises teóricas sobre elementos da subjetividade individual e social no contexto não-formal. Sob o caráter da pesquisa como um processo comunicacional e 
dialógico, na égide da Epistemologia Qualitativa, a pesquisadora se permitiu postergar a fase de utilização dos instrumentos individuais para depois do término do Projeto. Em nossa opinião, essa decisão se provou crucial para viabilizar, na utilização dos instrumentos individuais, momentos de forte abertura e implicação emocional, essenciais para a qualidade da construção das informações.

Acerca do pensamento crítico sobre a educação não-formal, em sua inevitável comparação e inter-relação com a educação formal, escolar, pensamos que as análises realizadas, apontam para a importância da multiplicidade de contextos de aprendizagem, para além da educação formal, tendo em vista as formas complexas com que a subjetividade social, produzida em diferentes espaços sócio-relacionais, se expressa na configuração subjetiva da ação do aprender. Concordamos, assim com as ideias de Mitjáns Martínez (1995) quando a autora coloca que, para além das instituições mais básicas de família e escola, aspectos diversos da sociedade como um todo participam, como produção subjetiva da pessoa, no desenvolvimento da criatividade individual, desde as necessidades socioeconômicas até as possibilidades que ela [a sociedade] oferece para o desenvolvimento do indivíduo em termos de instrução, cultura, emprego ou, de outro lado, dos valores, metas e ideais que promove.

Tendo em vista um sistema educacional que promova uma formação orientada para o desenvolvimento de recursos subjetivos favorecedores da criatividade na aprendizagem, a autora reconhece a importância de oportunidades de tarefas e trabalhos independentes que sejam tão diversificados como possível de forma a permitir possibilidades de eleição pela pessoa. Em suas palavras, (MITJÁNS, 1995, pg. 157) (tradução nossa)

A possibilidade de eleição contribui para que o aluno valore diferentes alternativas e escolha a que mais se corresponde com seus interesses e projetos. Isso facilita a implicação pessoal com a realização do trabalho selecionado. Além do mais, estimula a segurança do jovem em si mesmo, o que está muito vinculado ao exercício da tomada de decisões que necessariamente se expressa na individualização de uma alternativa. 
Assumimos que a ampla gama de espaços de educação não-formal oferece precisamente oportunidades para essas possibilidades de eleição.

Ressaltamos ainda o fato de que, nas três participantes da pesquisa, ainda que excelentes alunas no contexto escolar, a relação com a aprendizagem escolar não se configurava como favorecedora do desenvolvimento de recursos subjetivos vinculados à expressão da criatividade no processo de aprendizagem. Em Camile, a aprendizagem escolar se constituía como uma mera obrigação a se passar, menos relevante em sua vida do que suas atuações políticas, extracurriculares, no grêmio estudantil, no Conselho de Classe e como presidente da turma. Em Estela, a relação com a aprendizagem escolar era marcada pela produção subjetiva relacionada à necessidade de ser bem avaliada, por seu histórico de boa aluna e por seu conforto para o estudo e realização de provas. Por fim, em Mika, a aprendizagem escolar era marcada por sentimentos de desconforto e incapacidade para o estudo individual, sistemático e teórico.

Essas construções interpretativas se apresentam em conformidade com as conclusões da tese de AMARAL (2011), sobre o desenvolvimento da constituição subjetiva de alunos criativos derivar-se de um conjunto de experiências de vida que estão, em geral, não circunscritas à educação escolar em si.

Consideramos, nos casos de Camile, Estela e Mika, que suas respectivas relações com a aprendizagem escolar se desenvolvem integradas a uma configuração subjetiva social do papel da educação escolar no ensino médio como relacionado à fase preparatória para o vestibular. Configuração essa que se expressa de múltiplas formas nas representações, valores e práticas sociais. Expressa-se na abordagem conteudista, passiva e reprodutivista desta etapa de ensino, na ênfase em processos avaliativos de assimilação de conteúdos e na instrumentalização do aprender por parte dos alunos (aprender é importante para passar no vestibular!). Expressa-se ainda na ausência de estratégias de ensino orientadas para favorecer o desenvolvimento do prazer do aprender pelo aprender e, com isso, para promover o desenvolvimento de indivíduos aprendentes autônomos e permanentes. Expressa-se, por fim, na promoção de uma representação social de que a aprendizagem ocorre exclusivamente e/ou primordialmente dentro da escola.

Consideramos que contextos não-formais de aprendizagem, ao oferecer espaços alternativos de aprendizagem, poderiam abrir caminhos para produções subjetivas 
alternativas às associadas à atual configuração subjetiva social do papel da educação escolar no ensino médio.

Tendo em vista estas considerações, para além das contribuições teóricas já apontadas, acreditamos que a pesquisa pode fornecer subsídios apontando para áreas mais amplas de atuação. Elencamos a seguir as seguintes contribuições:

- Para a implantação de políticas públicas ligadas a ações educativas em instituições ligadas à educação não-formal: o estudo fornece subsídios sobre a relevância e as particularidades da educação não-formal, a partir da consideração da dimensão subjetiva da pessoa e de sua formação contínua, tendo em vista o desenvolvimento de recursos subjetivos para a aprendizagem para a vida.

- Para a inter-relação entre instituições ligadas à educação não-formal e formal: na busca pela compreensão da complexidade com que especificidades do contexto nãoformal se expressam na dimensão subjetiva do aprendiz, em sua condição singular, o estudo pode auxiliar no entendimento de que a relação entre instituições da educação formal e não-formal deva se constituir como uma relação verdadeiramente nova e diferenciada, que promova a abertura e a construção conjunta das duas instituições, evitando a escolarização ${ }^{18}$ da educação não-formal.

○ Para a compreensão da avaliação da aprendizagem no contexto não-formal: na consideração da dimensão subjetiva do aprendiz, em sua condição singular, ao mesmo tempo histórica e atual, o estudo traz uma nova perspectiva que supera a tendência a uma avaliação predominantemente cognitiva da aprendizagem, impondo relevância não ao conteúdo aprendido, mas à qualidade da produção subjetiva frente à informação e ao aprendizado. Essa consideração desvenda tradicionais dilemas das pesquisas na área, entre eles, conforme apontado no capítulo I, (1) o da pouca aprendizagem de "conteúdos" nas instituições museais, (2) o da necessidade da consideração da trajetória de vida do participante na compreensão de seus processos

\footnotetext{
${ }^{18}$ Terminologia utilizada em aula da disciplina "Educação em Contextos Não-formais e Informais" cursada no ano de 2011, sob docência da professora Maria Helena Carneiro, da Faculdade de Educação da Universidade de Brasília, que se refere à reprodução, no contexto não-formal, de práticas avaliativas focadas exclusivamente na apreensão de conteúdos curriculares, mais comumente evidenciadas no contexto formal.
} 
do aprender no contexto não-formal, (3) o da consideração de que o aprendizado no contexto não-formal emerge de diferentes formas, em diferentes momentos de vida e, portanto, sua avaliação não deve se limitar a um momento pontual e específico, e (4) o da comparação com a aprendizagem escolar, entre outros.

- Para a formação de educadores em instituições ligadas à educação não-formal: ao serem abordados como recursos formativos, conhecimentos sobre a dimensão subjetiva da aprendizagem em contextos não-formais podem promover novas formas de conceber e realizar práticas da educação não-formal, tanto por parte de pedagogos e museólogos, quanto por parte de monitores.

- Para a capacitação de professores do ensino formal que participem de ações educativas não-formais: a consideração da dimensão subjetiva da aprendizagem no contexto não-formal pode promover novas práticas de aproveitamento de ações educativas não-formais que, ao invés de corroborar tradicionais formas de ensino e avaliação da aprendizagem escolar, promovam verdadeiramente uma abertura da escola para novas experiências onde o que se aprende é definido pelo aprendiz e onde não há necessidade de avaliação da aprendizagem. (Se a hegemonia histórica da escola enquanto instituição responsável pela educação e formação de cidadãos culminou em promover a representação da aprendizagem como exclusivamente associada à aprendizagem escolar, formal, a própria escola participaria de um processo de reversão deste quadro, reafirmando a autonomia e a continuidade de processos de aprender em diferentes contextos e perante à vida!)

Em contrapartida às possíveis contribuições, faz-se importante demarcar que ao longo da pesquisa nos deparamos com algumas limitações como a minha relativa pouca experiência com a Epistemologia Qualitativa que não me permitiu explorar, de forma mais aprofundada, possíveis sentidos subjetivos oriundos de outros espaços sociais, constituintes dos processos de aprendizagem das participantes, para além do Projeto e da escola. Ressalto ainda o grande desafio, talvez por minha formação em ciências sociais aplicadas em oposição à formação em psicologia ou psicologia da educação, em conduzir entrevistas em profundidade, que pudessem, por minha falta de experiência, invadir por demasiado a privacidade das participantes em suas contradições pessoais. 
No decorrer do percurso de pesquisa, muitas questões adjacentes ao problema estudado emergiram de nossas análises. Nesse sentido, apontamos alguns desdobramentos para pesquisas futuras que se abrem a partir do presente trabalho. Em primeiro, a importância de estudos longitudinais nas pesquisas sobre aprendizagem, e aprendizagem criativa, de forma a contemplar a expressão do aprendido em diferentes momentos e espaços da vida do aprendiz, superando pesquisas que, sob a histórica tradição da aprendizagem formal e escolar, tendem a enfatizar a busca pela compreensão da aprendizagem, e seus processos, em momentos e contextos pontuais e específicos. Um segundo desdobramento que nos pareceu interessante, tendo em vista nossas construções sobre a relevância da personalização da experiência da aprendizagem como processo subjetivo constitutivo da aprendizagem criativa em contextos não-formais, consiste o aprofundamento de estudos que investiguem as inter-relações entre a aprendizagem criativa, a movimentação subjetiva e processos relacionados à identidade de aprendizagem. 


\section{REFERÊNCIAS}

ALLEN, S. Looking for Learning in Visitor Talk: A Methodological Exploration. In: LEINHARDT, G.; CROWLEY, K.; KNUTSON, K. (eds.). Learning Conversations in Museums. Mahwah: Lawrence Erlbaum, 2002. p. 259-303.

AMARAL, A.L.S.N. A Constituição da aprendizagem criativa no processo de desenvolvimento da subjetividade. Tese de Doutorado. Universidade de Brasília, Brasília, 2011

AMARAL, A.L.S.N.; MITJÁNS MARTÍNEZ, A. Aprendizagem criativa no Ensino Superior: a significação da dimensão subjetiva. In: MITJÁNS MARTíNEZ, A.; TACCA, M.C.V.R. (Orgs.). A Complexidade da aprendizagem: destague para o Ensino Superior (p.149-192) Campinas: Alínea, 2009.

ANDERSON, D.; LUCAS, K.B.; GINNS, I.S. Theoretical perspectives on learning in an informal setting, In: Journal of Research in Science Teaching, Vol. 4, 2003

ANDERSON, M. Visitors' Long-term Memories of World Expositions David Anderson, In: Curator: The Museum Journal, Vol. 46, 2003

BIZERRA, A. F. Atividade de aprendizagem em museus de ciências. Tese (doutorado) Faculdade de Educação, USP, 2009

BIZERRA, A. F.; MARANDINO, Martha. A concepção de aprendizagem nas pesquisas em educação em museus. In: VII Encontro Nacional de Pesquisa em Educação em Ciências, 2009, Florianópolis. Anais do VII ENPEC, 2009.

BOZHOVIC, L.I. La Personalidad y su formación em la edad infantil. Ciudad de la Havana: Pueblo y Educación,1985

CSIKSZENTMIHALYI, M. and HERMANSON, K. Intrinsic Motivation in Museums: Why Does One Want to Learn? Public Institutions for Personal Learning: Establishing a Research Agenda. J. Falk and L. Dierking. Washington D.C., American Association of Museums, 1995, pg.67-77.

COSTA, A.F. et all Pensando a Relação Museu-Escola: O MAST e os Professores, VI ENPEC - Encontro Nacional de Pesquisa em Educação em Ciências, Florianópolis (Novembro) 2007

ESHACH, H. Bridgin In-school and Out-of-school Learning: Formal, Non-formal, and Informal Education. In: Journal of Science Education and Technology, Vol. 16, No. 2, April 2007

FALCÃO, A. Museu como lugar de memória, In: Salto para o Futuro, 2009, Disponível em: tvbrasil.org.br/fotos/salto/series/153511MuseueEscola.pdf

. Padrões de Interação e Aprendizagem em Museus de Ciências. Tese (mestrado) Instituto de Ciências Biomédicas, modalidade Educação, Gestão e Divulgação em Biociências, UFRJ, 1999 
FALK, J.; DIERKING, L. The Museum Experience. Washington: Whalesback Books, 1992.

FALK, J.; STORKSDIECK, M. Learning science from museums. História, Ciências, Saúde - Manguinhos, v. 12 (supplement), p. 117-43, 2005.

FALK, J.; ADELMAN, L.M. Investigating the impact of prior knowledge and interest on aquarium visitor learning, In: Journal of Research in Science Teaching, 2003

FALK,J. Museums as institutions for personal learning, In: Daedalus, Vol. 128, 1999

The director's cut: Toward an improved understanding of learning from museums, In: Science Education, Vol. 88, 2004

An Identity-Centered Approach to Understanding Museum Learning, In: Curator: Museum Journal, Vol. 49, Issue 2, p. 151-166, Abril 2006

FERNÁNDEZ, F.S. El aprendizage fuera de la escuela. Madri: Ediciones Acadêmicas, 2006.

FRANCO, S. P. O Impacto de Exposições Museológicas na Motivação para Aprender Ciências. Tese (mestre) Instituto de Física, Unb, 2008

GASPAR,A. Museus e Centros de Ciências: conceituação e proposta de um referencial teórico. Tese (doutorado). Faculdade de Educação USP, 1993

GONZÁLEZ-PIENDA ET AL. Autorregulación del aprendizaje y estratégias de estudio. In: GONZÁLEZ-PIENDA, J.A.; PÉREZ, J.C.N; PÉREZ,L.A; VÁZQUEZ, E.S. (orgs.) Estrategias de Aprendizaje: concepto, evaluación e intervención, Madrid: Pirámide, 2002

GONZÁLEZ REY, F.; MITJÁNS MARTÍNEZ, A. La personalidad: su educación y desarrollo. La Habana: Pueblo y Educación, 1989

GONZÁLEZ REY, F. Epistemología cualitativa y subjetividad. São Paulo: EDUC, 1997.

. Subjetividad, sujeto y construcción del conocimiento: $E$ aprendizaje desde outra óptica. Revista Linhas Críticas, Vol. 4, Núm. 7-8, p. 1721, Brasília: FE/Unb, 1998

. Personality, Subject and Human Development: The Subjective Character of Human Activity. In: CHAIKLIN, S.; HEDEGAARD, M.; JENSEN,U. (Orgs.) Activity Theory and Social Practice, Oxford: Aarchus University Press, 1999a

La Investigatión Qualitativa em Psicologia: rumos e desafíos. São Paulo: EDUC, 1999b. 
. La categoria sentido subjetivo e su significación en La construción Del pensamiento psicológico. Contrapontos Psicologia Históricocultural Revista de Educação da Univali, Rio de Janeiro: Univali, 2001

. El aprendizage en el enfoque histórico-cultural - sentido y aprendizage. In: TIBALLI, E.F.A., e CHAVES, S.M. (orgs.) Concepções e práticas em formação de professores: diferentes olhares, Rio de Janeiro: DP\&A Ed., 2003

. O sujeito, a subjetividade e o outro na dialética complexa do desenvolvimento humano. In: MITJÁNS MARTÍNEZ, A.; SIMÃO, L.M. (Orgs). O outro no desenvolvimento humano: diálogos para a pesquisa e a prática profissional em psicologia. São Paulo: Pioneira Thomson Learning, 2004

. Sujeito e Subjetividade: Uma aproximação histórico-cultural. São Paulo: Thomson - Pioneira, 2005a

- Pesquisa qualitativa e subjetividade: os processos de construção da informação.São Paulo: Thomson, 2005b

. O Valor Heurístico da Subjetividade na Investigação Psicológica. In: GONZÁLEZ REY, F.L. (org.) Subjetividade, Complexidade e Pesquisa em Psicologia, São Paulo: Thomson, 2005c, p. 27-52

. Psicoterapia, Subjetividade e Pós-Modernidade. Uma aproximação histórico-cultural. São Paulo: Thomson, 2007

As categorias de sentido, sentido pessoal e sentido subjetivo: sua evolução e diferenciação na teoria histórico-cultural. Psicologia da Educação. v. 24, p.155-179, 2007a

O Sujeito que Aprende: desafios do desenvolvimento do tema da aprendizagem na psicologia e na prática pedagógica. In: TACCA, M.C. (org.) Aprendizagem e trabalho pedagógico, Campinas: Alínea, 2ª Ed., 2008

. La significación de Vigotski para la consideración de lo afectivo en la educación: Las bases para la cuestión de la subjetividad. Revista Electrónica Actualidades Investigativas en Educación, Vol. 8, Núm. Especial, Costa Rica: Universidad de Costa Rica, 2009a

- Questões teóricas e metodológicas nas pesquisas sobre aprendizagem. In: MITJÁNS, M.A.; TACCA, M.C.V.R. (Orgs.) A Complexidade da Aprendizagem. Campinas: Alínea, 2009b.

. El pensamiento de Vygotsky: contradicciones, desdoblamientos y desarrollo. México: Trillas, 2010a

. Las categorias de sentido, sentido personal y sentido subjetivo em uma perspectiva histórico-cultural: um camino hacia uma nueva definición de subjetividad. In: La Revista Universitas Psychologica, Vol. 9, Núm. 1, Colombia: Pontificia Universidad Javeriana, 2010b 
Advancing on the Concept of Sense: Subjective Sense and Subjective Configurations in Human Development In: Hedegaard, M.; EDWARDS, A.; FLEER, M. (orgs.) Motives Children's Development Cultural Historical Approaches, Cambridge: Cambridge University : Press, 2011

- Human Development in question: new alternatives from a cultural historical approach to psychical development. No prelo.

Sentidos subjetivos, linguagem e sujeito: implicações epistemológicas de uma perspectiva pós-racionalista em psicoterapia. In: $O$ Campo das Psicoterapias: reflexões atuais.Curitiba: Juruá, 2012a

A Configuração subjetiva dos processos psíquicos: avançando na compreensão da aprendizagem como produção subjetiva In: MITJÁNS, A.; SCOZ, B.; CASTANHO, M.I.S (Orgs.) Ensino e Aprendizagem: A Subjetividade em Foco, Brasília: Liber Livro, 2012b

GRIFFIN, J. ET AL. Museums Actively Researching Visitor Experiences and Learning (MARVEL): a methodological study. Open Museum Journal, Vol. 7, 2005

HEIN, G. Learning in the Museum. London: Routledge. 1998.

INSTITUTO BRASILEIRO DE MUSEUS (IBRAM). Definição de Museus, Comitê Internacional de Museus - ICOM. Definição aprovada pela 20a Assembleia Geral, Barcelona, Espanha, 6 de julho de 2001. Ministério da Cultura, 2009-2013. Disponível em: <http://www.museus.gov.br/museu/>. Data de acesso: 30 de jan. 2013.

KOPTCKE, L.S. Analisando a dinâmica da Relação Museu- Educação - Formal. In: KOPTCKE, L. S. E VALENTE, M. E. A., (orgs.) Caderno do Museu da Vida O formal e o não-formal na dimensão educativa do museu 2001/2002, Rio de Janeiro: Museu da Vida - Fiocruz. pp.16-25

KELLY, L. What is learning ... and why do museums need to do something about it ?, Artigo apresentado no seminário Why Learning?, Australian Museum/University of Technology Sydney, Nov, 2002 . Visitors and Learners: Adult Museum Visitors' Learning Identities.

Sydney: University of Technology, 2007

LEONTIEV, A. O desenvolvimento do psiquismo. Lisboa: Horizonte, 1978

LURIA, A.R. Curso de Psicologia Geral. Rio de Janeiro: Civilização Brasileira, 1979 , v.I

MARANDINO, M. Enfoques de Educação e Comunicação nas Bioexposições de Museus de Ciências. Bauru : Revista Brasileira de Pesquisa em Educação em Ciências, v. 3, n. 1, p. 103-109, 2003. 
. Museu como lugar de cidadania. In: Salto para o Futuro Museu e escola: educação formal e não-formal/TV Escola,2009

MITJÁNS MARTíNEZ, A.. Como desarrollar la creatividad en la escuela. In: MITJÁNS MARTÍNEZ, A. (Org.) Pensar y Crear. Estrategias, programas e métodos, v.1, p.156-208, 1ed., Cuba: La Habana, 1995

. Criatividade, Personalidade e Educação. Campinas, SP: Papirus,

1997

Pensar, crear y transformar : desafíos para la educación. Anais I Simpósio Multidisciplinar Pensar Criar e Transformar. Universidade de São Marcos, 2000.

- La interrelación entre investigación psicológica y práctica educativa: un análisis crítico a partir del campo de la creatividad. In: Z. Del Prette (Org.). Psicologia Escolar/Educacional, Saúde e Qualidade de vida: explorando fronteiras. Campinas: Átomo, 2001. p. 87-111.

. A criatividade na escola: três direções de trabalho. Revista Linhas Críticas, v. 8, n.15, p.189-206, 2002

O outro e sua significação para a criatividade: implicações educacionais. In: SIMÃO, L.; MITJÁNS MARTÍNEZ, A. (Org.). O outro no desenvolvimento humano. São Paulo: Thomson, 2004. p. 77-97.

A Teoria da Subjetividade de González Rey: Uma Expressão do Paradigma da Complexidade na Psicologia. In: GONZÁLEZ REY, F.L. (org.) Subjetividade, Complexidade e Pesquisa em Psicologia, São Paulo: Thomson, 2005

Criatividade no trabalho pedagógico e criatividade na aprendizagem: uma relação necessária?. In: TACCA, M C. V. R. (Org.) Aprendizagem e Trabalho Pedagógico. Campinas: Alínea, 2008a, 2ª ed., p 6994.

A Criatividade com o Princípio Funcional da Aula: Limites e Possibilidades. In: VEIGA, I.P.A. (org.) Aula: Gênese, dimensões, princípios e práticas, Campinas, SP: Papirus, 2008b

. Vygotsky e a Criatividade: novas leituras, novos desdobramentos. In: GIGLIO, Z. G.; WESCHLER, S. M.; BRAGOTO, D. (orgs.) Da Inovação à Criatividade. ${ }^{1}$ Ed. Campinas: Papirus, 2009a

Processos de Aprendizagem na Pós-graduação: um estudo exploratório. In: MITJÁNS, A. M.; TACCA, M.C.V.R. (Orgs.). A Complexidade da aprendizagem: destague para o Ensino Superior (p.149-192) Campinas: Alínea, 2009b.

Aprendizagem Criativa: uma aprendizagem diferente. In: MITJÁNS, A.M.; SCOZ,B.J.L; CASTANHO, M.I.S. (orgs.) Ensino e Aprendizagem: a subjetividade em foco, Brasília: Liber Livros, 2012a 
MITJÁNS MARTÍNEZ, A. e GONZÁLÉZ REY, F. O Operacional e o Subjetivado na Aprendizagem Escolar: Pesquisas e Reflexões. In: MITJÁNS, A.M.; SCOZ,B.J.L; CASTANHO, M.I.S. (orgs.) Ensino e Aprendizagem: a subjetividade em foco, Brasília: Liber Livros, 2012

MITJÁNS MARTÍNEZ, A. Aprendizagem Criativa. Desafios para a prátcia pedagótica. In: MITJÁNS, NUNES (org.) Didática e Formação de Professores, ljuí: Ed. Unijuí, 2012b

MORA, M.C.S Diversos enfoques sobre as visitas guiadas nos museus de ciência In: MASSARANI, L.; MERZAGORA, M.; RODARI, P. (org) Diálogos \&Ciência Mediação em museus e Centros de Ciência,Rio de Janeiro: Museu da Vida/Casa de Oswaldo Cruz/Fiocruz, 2007

MORAES, M. C. Pensamento eco-sistêmico Educação, aprendizagem e cidadania no século XXI. Petrópolis: Editora Vozes, 2004

MORIN, E. Introdução ao Pensamento Complexo, Porto Alegre: Sulina,3를 Ed., 2007

MORTARA, A. Desafios da Relação Museu-Escola, In: Comunicação \& Educação, São Paulo, set/dez.1997

NUNES, A.I.B.L; SILVEIRA, R.N. Psicologia da Aprendizagem: processos, teorias e contextos,Brasília: Liber Livro, 2009

OLIVEIRA, C. T. Estratégias de aprendizagem e subjetividade em estudantes criativos do ensino superior. Dissertação de Mestrado, Universidade de Brasília, Brasília, 2010.

PÉREZ, J.C; GONZÁLEZ-PIENDA, J.A; MONTERO, C.R. Autorregulación del aprendizaje y estratégias de estudio. In: GONZÁLEZ-PIENDA, J.A.; PÉREZ, J.C.N; PÉREZ,L.A; VÁZQUEZ, E.S. (orgs.) Estrategias de Aprendizaje: concepto, evaluación e intervención, Madrid: Pirámide, 2002

POZO, J.I. Aprendizes e Mestres - a nova cultura da aprendizagem. Porto Alegre:Artmed, 2002.

RENNIE, L.J. and JOHNSTON,D.J. The nature of learning and its implications for research on learning from museums, In: Science Education, Vol. 88, 2004

REGO, T.C. (org.) Cultura, Aprendizagem e Desenvolvimento. Petrópolis: Vozes, 2011

RIGON, A. J.; ASBAHR, F.S.; MORETTI, V.D. Sobre o Processo de Humanização In: MOURA, M. O. (org) A atividade pedagógica na teoria históricocultural Brasília: Liber Livro, 2010 
ROCHA, V.; LEMOS, E.L. e SCHALL, V. Avaliação da aprendizagem sobre saúde em visita ao Museu da Vida. História, Ciências, Saúde - Manguinhos, Rio de Janeiro, v.17, n.2, abr.-jun. 2010

ROGERS, A. Looking again at non-formal and informal education - Towards a new paradigm, 2004. Disponível em:

<http://www.infed.org/biblio/non_formal_paradigm.htm> Acessado em:

setembro 2007

ROSSATO, M. O movimento da subjetividade no processo de superação das dificuldades de aprendizagem escolar. Tese de doutorado, Universidade de Brasília, 2009

SAPIRAS, A. Aprendizagem em Museus: uma análise das visitas escolares no Museu Biológico do Instituto Butantan. 2007. 155 fls. Dissertação (Mestrado em Educação), Universidade de São Paulo, 2007

SCHAUBLE, L., LEINHARDT, G. and MARTIN, L. A framework for organising a cumulative research agenda in informal learning. Journal of Museum Education, no. 22(2/3), 3-8, EUA, 1997

SANTOS, G. Os impactos dos alunos com desenvolvimento atípico na subjetividade do professor e a configuração do trabalho pedagógico. Dissertação de mestrado, Universidade de Brasília, 2010

SMITH, M. Non formal education. Disponível em <http://www.infed.org/biblio/nnonfor.htm> 1996. Acessado em: agosto, 2011

TRILLA, J. A Educação não-formal. In: ARANTES, V.A.(Org.) Educação formal e não-formal. São Paulo: Summus, 2008.

TUNES, E.;TACCA, M.C.; MITJÁNS MARTÍNEZ, A. Uma crítica às teorias clássicas da aprendizagem e à sua expressão no campo educativo, Revista Linhas Críticas, Vol. 12, Núm. 22, p. 109-130, Brasília: FE/Unb, 2006

VIGOTSKI, L.S. A Construção do pensamento e da linguagem. São Paulo: Martins Fontes, 2010

Historia del desarrollo de las funciones psíquicas superiores. In: Obras escogidas III. Madri: Visor, 1933-1996 


\section{APÊNDICE A}

\section{Apresentação da Pesquisa: Leitura em Conjunto do}

\section{Livro "Crianças Famosas: Bach"}

\section{Roteiro:}

\section{1) Apresentações Pessoais \\ 2) Leitura em Grupo do Livro "Crianças Famosas: Bach" \\ 3) Discussão a partir das perguntas conforme quadro a seguir:}

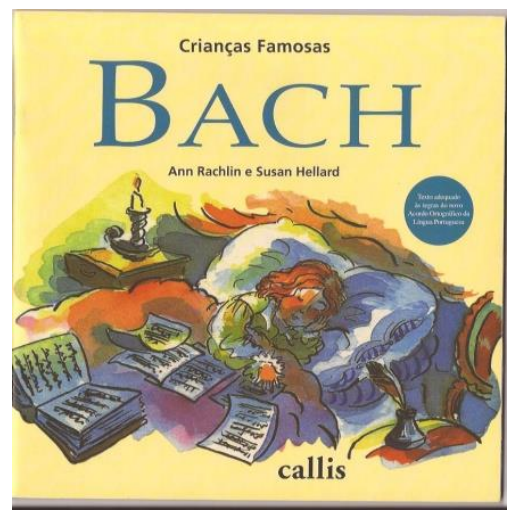

\begin{tabular}{|c|c|c|}
\hline \multirow{2}{*}{$\begin{array}{l}\text { Quais elementos, } \\
\text { podemos sugerir, } \\
\text { demonstram... }\end{array}$} & \multicolumn{2}{|c|}{ Indicadores } \\
\hline & $\begin{array}{l}\text { Experiência de } \\
\text { Vida }\end{array}$ & Emoções \\
\hline \multirow{3}{*}{$\begin{array}{l}\text {...ser Christopher } \\
\text { uma pessoa de } \\
\text { grande relevância } \\
\text { para Johann? }\end{array}$} & $\begin{array}{l}\text { (Acolheu bem após a morte dos } \\
\text { pais.) }\end{array}$ & $\begin{array}{l}\text { (Acolhimento; sensação de reconstrução } \\
\text { da família) }\end{array}$ \\
\hline & $\begin{array}{l}\text { (Era compositor e tocava órgão na } \\
\text { cidade onde moravam.) }\end{array}$ & (Exemplo/ referência; respeito; ideal) \\
\hline & $\begin{array}{l}\text { (Levava Johann a escola e dava-Ihe } \\
\text { aula de cravo) }\end{array}$ & $\begin{array}{l}\text { (Referências em relação ao método e à } \\
\text { disciplina) }\end{array}$ \\
\hline $\begin{array}{l}\text {..., em Johann, uma } \\
\text { condição de sujeito? }\end{array}$ & $\begin{array}{l}\text { (Roubo do livro da estante; } \\
\text { Plano de Cópia do livro; } \\
\text { Cópia do livro.) }\end{array}$ & $\begin{array}{l}\text { (Audácia na ruptura com o irmão; auto- } \\
\text { confiança; coragem; perspicácia de } \\
\text { pensar estrategicamente) }\end{array}$ \\
\hline $\begin{array}{l}\text {... ser a música de } \\
\text { grande relevância } \\
\text { para Johann? }\end{array}$ & $\begin{array}{l}\text { (Casa sempre cheia de música; } \\
\text { Adorava o momento das aulas; } \\
\text { Irmão músico como referência) }\end{array}$ & $\begin{array}{l}\text { (Sensação de acolhimento com a música; } \\
\text { Paixão pela música; Sentimento de } \\
\text { onipresença da música na vida) }\end{array}$ \\
\hline $\begin{array}{l}\text {... ser a } \\
\text { aprendizagem de } \\
\text { música de grande } \\
\text { relevância Johann? }\end{array}$ & $\begin{array}{l}\text { (Adorava momento das aulas, } \\
\text { achado chato ter que abandonar o } \\
\text { instrumento e fazer as lições de } \\
\text { casa; } \\
\text { Interesse pelo livro de música do } \\
\text { irmão; } \\
\text { Cópia de milhares de notas; } \\
\text { Memorização de música completa.) }\end{array}$ & $\begin{array}{l}\text { (Interesse e satisfação pelas aulas de } \\
\text { cravo; } \\
\text { Interesse, pessoal, em aprender, de } \\
\text { outras formas (pelo livro do irmão) e } \\
\text { frustração por não poder ter acesso) }\end{array}$ \\
\hline
\end{tabular}

4) Discussão: $O$ que vocês acham sobre essa forma de aprender em Bach? Ela é comum? Ela acontece com frequência na escola?

5) Como Bach, vocês tem paixão por aprender alguma coisa? O quê?

6) Apresentação da pesquisa. 


\section{APÊNDICE B \\ Entrevista semi-estruturada I}

1) Informações biográficas:

- Onde nasceu

- Onde viveu (o que acha desse(s) lugar(es))

- Onde mora (o que acha desse lugar)

- Com quem mora

- Como é a sua família

- Quais são seus hobbies (porque gosta deles)

- Qual profissão deseja

2) Informações Pessoais:

- Sentido da vida

- Projetos sonhados (realizados ou não realizados)

- Mudanças necessárias na sua vida

- Experiências mais valiosas e mais frustantes

- Pessoas importantes na sua vida

- O melhor e o pior lugar 


\section{APÊNDICE C}

\section{Entrevista semi-estruturada II}

1) Informações sobre a Vida Escolar

- O que você mais gosta na escola? Porque?

- Como é como aluno na escola

- Quais disciplinas mais gosta. Porque?

- Gosta de estudar? Porque?

- Relação com professores

- Relação com colegas

- Conhecimentos e descobertas significativas a que chegou por si mesmo

- Participa de eventos, feiras, olimpíadas, grupos de interesse e/ou concursos de conhecimentos?

- Como se sente em relação às provas? E às próprias notas e avaliações finais?

- Cite três momentos marcantes da vida escolar que gostariam de reviver e três momentos que não gostariam de reviver.

2) Sobre a aprendizagem fora da escola (não-formal e informal)

- Em que situações mais aprende fora da escola

- Em que lugares mais aprende fora da escola

- Pessoas significativas 


\section{APÊNDICE D}

\section{Completamento de Frases}

\begin{tabular}{|c|c|}
\hline 1. Eu gosto & 38. Meus estudos \\
\hline 2. O tempo mais feliz & 39. Tem conteúdo que aprendo pouco porque \\
\hline 3. Gostaria de saber & 40. Minha vida futura \\
\hline 4. Lamento & 41. Farei o possível para alcançar \\
\hline 5. Meu maior medo & 42. Frequentemente, reflito sobre \\
\hline 6. Na escola & 43. Proponho-me a \\
\hline 7. Não posso & 44. Meu maior tempo dedico a \\
\hline 8. Sofro & 45. Sempre que posso \\
\hline 9. Fracassei & 46. Luto \\
\hline 10. A leitura & 47. Frequentemente, sinto \\
\hline 11. Meu futuro & 48. Diante de situações novas \\
\hline 12. Aprendo quando & 49. O passado \\
\hline 13. Estou melhor & 50. Esforço-me \\
\hline 14. Algumas vezes & Perguntar \\
\hline 15. Tenho certeza que & 51. As contradições \\
\hline 16. Minha preocupação principal & 52. Minha opinião \\
\hline 17. Desejo & 53. Penso que os demais \\
\hline 18. Meu maior professor foi & 54. O lar \\
\hline 19. Secretamente eu & 55. Incomoda-me \\
\hline 20. Eu & 56. Ao deitar-me \\
\hline 21. Meu maior problema é & 57. A gente \\
\hline 22. Durante as aulas e gosto de & 58. Aprender é \\
\hline 23. Amo & 59. Sinto \\
\hline 24. Minha principal ambição & 60. Quando crio algo novo \\
\hline 25. Eu prefiro & 61. Minha família \\
\hline 26. Meu principal problema & 62. Quando era criança \\
\hline 27. Quero ser & 63. Quando tenho dúvidas \\
\hline 28. Creio que minhas melhores atitudes são & 64. No futuro \\
\hline 29. Nesse ano letivo & 65. Necessito \\
\hline 30. A felicidade & 66. Meu maior prazer \\
\hline 31. Considero que posso & 67. O saber tem "sabor" quando \\
\hline 32. Esforço-me diariamente por & 68. Aprendo na \\
\hline 33. Sinto dificuldade & 69. Odeio \\
\hline 34. Meu maior desejo & 70. Quando estou só \\
\hline 35. Sempre quis & 71. Meu maior temor \\
\hline 36. Gosto muito & 72. Deprimo-me \\
\hline 37. Minhas aspirações são & 73. O estudo \\
\hline & 74. Meus amigos \\
\hline & 75. Meus colegas \\
\hline & 76. O ser humano \\
\hline & 77. Não me sinto preparada \\
\hline
\end{tabular}




\section{APÊNDICE E \\ Entrevista semi-estrurada III \\ (Com foco nas estratégias de Aprendizagem)}

1) O que é aprender para você?

\section{PLANEJAMENTO/PLANIFICACÃO:}

2) Como você estuda?

3) Como você aprende?

\section{SUPERVISÃO:}

4) Como comporta-se durante os estudos? Costuma controlar os procedimentos das tarefas? Consegue manter a atenção? De que forma?

5) O que sente quando aprende?

\section{REVISÃO:}

6) Como avalia a sua forma de se esforçar e de utilizar o seu tempo para estudar?

7) De que forma você age quando se depara com situações ou tarefas extremamente difíceis ou complexas?

8) Ao perceber que não está conseguindo estudar e/ou aprender num determinado contexto, como reage?

\section{VALORACÃO:}

9) Como você avalia seu processo de estudar e aprender?

\section{ESTRATÉGIAS COGNITIVAS:}

10) Como você faz para memorizar informações?

11) Como você faz para compreender um texto?

\section{ESTRATÉGIAS MOTIVACIONAIS:}

12) Quando você se sente animado a estudar?

13) Quando você se sente animado a aprender?

14) Como lida com as suas emoções? 


\section{APÊNDICE F \\ Entrevista semi-estrurada IV \\ (com auxílio do Portfólio do Projeto)}

1) Informações sobre a motivação para participar do projeto:

- Porque você resolveu participar do projeto de Fortalecimento do PSE na Escola?

- Quais eram as suas expectativas?

- O que significava para você ser um estudante participante do projeto?

2) Informações sobre de avaliação do projeto:

- Três momentos de grande aprendizagem

- Três momentos que você não gostou

- O que mudaria?

- Como vê a diferença de aprender no projeto e na escola?

3) Informações sobre aprendizagens no projeto:

- Nos últimos meses, em quais situações relembrou os aprendizados projeto Fortalecimento da Participação Juvenil no PSE?

- Cite uma situação em específico e explique o que pensou e o que sentiu.

- Nos últimos meses, você aprofundou algum conhecimento relacionado às temáticas do projeto? Como e o que aprendeu? 


\section{APÊNDICE G}

\section{Redação}

Considerando suas aprendizagens sobre saúde no projeto Fortalecimento do PSE nas Escolas e a polêmica sobre o Programa Mais Médicos, descrita no parágrafo abaixo, escreva suas reflexões sobre o seguinte tema:

A recente polêmica em torno da vinda de médicos estrangeiros para o país reacendeu uma antiga e vasta discussão: os desafios da saúde pública no Brasil. Falta de médicos em regiões afastadas em contraponto à intensa concentração nas grandes cidades, ausência de estrutura nos hospitais da rede pública, além da dificuldade em conseguir atendimento no SUS são alguns dos inúmeros problemas que atingem os brasileiros diariamente. Mas quais caminhos nosso país deve percorrer para conseguir alterar essa realidade no Brasil?. 


\section{APÊNDICE H \\ Entrevista semiestruturada com monitores do Projeto}

Com o objetivo de auxiliar o processo de seleção das participantes da pesquisa, a entrevista semiestruturada foi realizada em dois momentos a saber:

1. Apresentação da temática da pesquisa

2. Perguntas sobre impressões dos monitores com relação a indicadores funcionais de criatividade na aprendizagem de participantes do Projeto. Entre eles:

- Realização de perguntas interessantes;

- Questionamento e problematização da informação;

- Percepção de contradições e lacunas no conhecimento;

- Estabelecimento de relações remotas e pertinentes;

- Proposição de várias alternativas e hipóteses ante os problemas a resolver;

- Solução inovadora de problemas. 


\section{ANEXO I - \\ Programa do curso do Projeto,}

(conforme ordem de execução, ou seja, ordem diferenciada da prevista originalmente pelo projeto político pedagógico do curso)

> Módulo I -Contextualização da Proposta e Apresentação das instituições organizadoras e dos participantes

> Módulo II - Saúde e Educação

> Módulo III - Programa de Saúde na Escola

Módulo IV - Democracia, Participação e Protagonismo Juvenil

Módulo V - Comunicação e Mobilização

Módulo VI - Diagnostico Rápido Participativo

> Módulo VII - Encerramento 


\section{ANEXO II \\ Programa do Fórum do Projeto}

(editado para fins da pesquisa)

\section{- Dia 22 de agosto:}

8h: Acolhimento

$>$ 8h30: Mesa de Abertura

$>$ 09h30: $1^{\mathrm{a}}$ Roda dialogada Tema da roda: Saúde, Cidadania e juventude.

Escola: 01

$>$ 10h45: $2^{\mathrm{a}}$ Roda dialogada

Tema da roda: PSE e Alimentação Saudável - Perspectivas e desafios.

Escola: 03

$>$ 12h: Apresentação Cultural - Grupo Juventude pela Saúde

$>$ 12h10: Almoço

$>$ 13h30: $3^{\mathrm{a}}$ Roda dialogada

Tema da roda: Qualidade de vida e Comunidade Escolar.

Escola: Escola 04

14h45: 4⿳亠口冋 Roda dialogada

Tema da roda: Violência e Vulnerabilidade Social.

Escola: 02

$>$ 15h45: Informes

> Apresentação Cultural - Grupo Mar Vermelho - Sobradinho

$>$ 16h30min: Encerramento

- Dia 23 de agosto:

$>$ 8h30: Acolhimento

$>$ 9h: Grupos de trabalhos

$\checkmark$ Grupo de Trabalho Saúde, Cidadania e juventude.

$\checkmark$ Grupo de Trabalho PSE e Alimentação Saudável - Perspectivas e desafios.

$\checkmark$ Grupo de Trabalho Qualidade de vida e Comunidade Escolar.

$\checkmark$ Grupo de Trabalho Violência e Vulnerabilidade Social.

$>$ 12h: Almoço

$>$ 13h45: Plenária Final

$>$ 16h: Apresentação Cultural

$>$ 16h30min: Encerramento 